

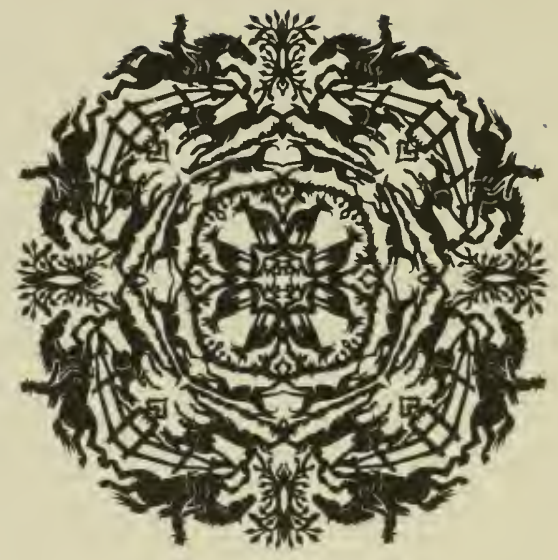

JOHN A.SEAVERNS 


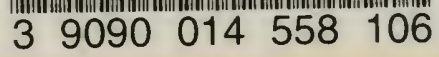

Wherer Femily Library of Veterinary Medicine Cimuinos School of Veterinary Madicin? at Tufts University 200 Westboro Roed morth Ereilon, MA 0105 

No. 10

\section{ESSENTIALS}

$\mathrm{OF}$

\section{VETERINARY LAW}

BY

HENRY BIXBY HEMENWAY, A. M., M. D.

Fellow, American Academy of Medicine; Fellow, American Medical Association; Member, American Public Health Association;

Member, American Association of Railway Surgeons;

Member, American Statistical Association; etc.. etc.

AUTHOR

Legal Principles of Public Health Administration.

\section{CHICAGO}

AMERICAN JOURNAL OF VETERINARY MEDICINE 1916 
Copyright 1916

By

HENRY BIXBY HEMENWAY. 


\section{PREFACE}

Following the publication of my "Legal Principles of. Public Health Administration" there came a request for a handbook which could be used as a text in veterinary schools and agricultural colleges. About one-third of the graduates from the veterinary schools take the examination for entrance into the service of the national government, but up to the present time there has been no small text which gave them the needful information as to their duties, responsibilities, and limitations of authority in such service; and scientific farmers need a knowledge of their legal rights and liabilities in animal husbandry.

In writing the present work I have kept in mind the needs of several distinct classes, and have consequently divided it into four parts. The brief statement of the general legal principles involved, as found in Part I, is essential for all.

Veterinarians in private practice need to know their legal rights, responsibilities, and liabilities. The best insurance against claims for damages is found in a knowledge of the requirements of the law. The writer has had his attention called to several cases in which veterinarians have incurred liabilities by innocently violating common legal principles. It is a mistake to depend too much upon a knowledge of enacted statutes. The common law is more frequently violated by veterinarians. These principles most applicable to private practitioners, as found in Part II, should be mastered.

It is the veterinarian who is first consulted by animal owners when an animal has been injured, or has con- 
tracted an infectious disease through the negligence of another. While it is not intended that the veterinarian shall take the place of a lawyer, still, a knowledge of the principles, as contained in Part IV, will often enable him to serve his patrons better, and save them needless trouble and expense. The remainder of the book will be found useful for occasional reference.

Official veterinarians, whether they be connected with the Bureau of Animal Industry in the Department of Agriculture, or in state and local offices, should have a clear idea as to the limitations of their authority, and the nature of their responsibilities. In addition to the outline of their legal status, Part III gives a condensed statement of the present regulations of the B. of A. I., in the handling of stock, and the conduct of the meat industry. It is suggested that the inspector mark the margins of his book, opposite appropriate sections, with the numbers of official orders applicable where fuller details are needed. For example: The special disinfectant applicable in a given case may be changed at any time by scientific advancement, and this text therefore simply speaks of "disinfectants." The inspector may increasc the usefulness of his book by the appropriate notation.

General sanitarians may find this manual useful for occasional reference, though for them it is not intended that it will take the place of a more ample discussion found elsewhere. However, some sanitary inspectors may find herein as much as they need, and may therefore prefer it to the more expensive work.

The number and variety of actions at law in which stockmen are involved seems astounding; yet the principles governing are not numerous, and there is a general uniformity in the decisions handed down from the courts of appeal. Stockmen have gained a reputation for lawlessness, probably more because of ignorance of the simple principles of law, than because of inherent wickedness. Every stockman owes it to himself to be- 
come thoroughly familiar with such matters as are found in Part IV; and he will frequently find that reference to the remainder of the book will answer perplexing questions.

Lastly: The general uniformity of decisions relative to specific points, with the frequent raising of the same questions, indicates that members of the legal profession must have sometimes misled their patrons. It is not presumed that an attorney would intentionally deceive his client, but it is easier to get into court than to get out, and it seems probable that the "case" has been started as the result of the error of a lawyer first consulted. Where there is liability, it is the duty of the attorney to attempt a settlement out of court. It is hoped that attorneys practicing in rural communities will find this little book helpful, not as an exhaustive exposition of the law involved, but as an indication of the general interpretation bearing upon the problems. We have taken care to verify the citations, which will be found more ample in the table than in the text.

For those interested in a more complete discussion of administrative law, frequent reference has been made to my larger work, designated simply as "Public Health," the numbers referring to sections therein. Cross references to sections of these "Essentials" will be found to greatly assist the reader in mastering the subjects considered.

Henry B. Hemenway.

Evanston, Ill.

Dec. 27, 1915. 



\section{AUTHORITIES CITED}

Bannington-English Public Health Administration.

Blackstone's Commentaries-Chitty (Am. Ed.).

Brown (Jethro)-Underlying Principles of Modern Legislation

(1915).

Burns' Annotated Statutes of Indiana (1914).

Cooley-On Torts.

Freund-Police Power.

Greenleaf-On Eridence (16th Ed.).

Hemenway-Legal Principles of Public Health Administration.

Hurd's Revised Statutes of Illinois (1914).

Ingham-The Law of Animals.

Lawson-Law of Expert and Opinion Evidence.

McClelland-Civil Malpractice.

McGehee-Due Process of Law.

Mechem-Public Officers.

Meyer Verwaltungsrecht.

Mill-Representative Government ("Ereryman's" Ed.).

Reports of American Public Health Association.

Reports of Attorney General, Illinois.

Reports of Wisconsin Agricultural Experiment Station.

Revised Statutes of the United States.

Service Bulletins, Bureau of Animal Industry.

Session Laws, Illinois, 1911.

Sherman and Redfield-Negligence.

Story-Bailments.

Throop-Public Officers.

Van Zile-Bailments and Carriers.

Wharton-Criminal Law.

Wharton-Negligence.

Wyman-Administrative Law. 



\section{CONTENTS}

\section{PART I. \\ Pertaining to Legal Principles. \\ CHAPTER I.}

\section{General Principles.}

\$ 1. Importance of Fundamental Principles..

$\$ 2$. Common Law; Constitutions; Statutes... 4

$\S$ 3. Nation, State or City. 6

$\$$ 4. Division of Powers... 7

\$. Executive Orders, Law? .......... 9
$\S$ 6. Municipal Ordinances. 10

$\$ 7$. Judicial Legislation... 12

$\$$ 8. Acts Must Not Be Arbitrary ......... 13

\& 9. Duties and Powers Cannot Be Delegated.. 15 $\S 10$. Judicial Decisions.... 17

CHAPTER II.

Police Power, "Due Process," and Nuisances.

$\S 11$. Definition of Police Power .......... 20

§ 12. Police Power Resides in the States..... 21

\$13. Alienum Non Lacdat. 23 \$14. Police Power Is Above Private Rights.... 24 $\S 15$. Police Power Cannot

Be Alienated..... 25

$\$ 16$. No Property Right in

Articles Acquired or Used Contrary to

Law ..........26 26

\$17. Due Process of Law.. 27
\$18. Nuisance ......... 28

$\S 19$. Nuisance $\mathrm{Per} \mathrm{Se}$, and In Posse ........ 29

$\S 20$. Nuisance a Question of Fact .......... 30

821. Changes in Legal Nuisance ........... 33

$\S 22$. Treatment of Nuisances .......... 35

$\S 23$. City Must Not Commit Nuisance ....... 3s

\$24. Authority for Abatement, Not for Coustruction ....... 39 


\section{PART II. \\ Pertaining to Veterinary Practice. \\ CHAPTER III.}

R'egulation of the Practice of Veterinary Surgery.

\$30. Authority of the State 43

$\S 31$. License to Practice... 47

\$32. Standards for License 48

§3. Appointment of Examiners ........ 53

$\S 34$. Exceptions ....... 54

$\$ 35$. Certificate in the Place of License ....... 55

$\S 36$. License by Reciprocity 55 $\S 37$. The License Itself.... 57
$\S 38$. Revocation of License 59

$\S 39$. Attorney for Board of Examiners ......66 63

$\S 40$. What Constitutes Practice of Veterinary Medicine or Surgery? .......... 64

$\S 41$. Practice as a Company 67 $\S 42$. P r o s e cu t i o n s, by Whom? .......6 68

\section{CHAPTER IV.}

\section{LiABILITIES.}

$\S 45$. The Contract of a Veterinarian .....6 69

$\S 46$. Obligation to Attend. 70

$\$ 47$. Number of Calls..... 70

$\S 48$. Gratuitous Service ... 72

$\$ 49$. Ordinary Liability.... 75

$\$ 50$. Errors of Judgment. . 76

$\$ 51$. Liabilities for the Acts of Others ....... 78

$\S 52$. Liability of Partnership $\ldots \ldots \ldots \ldots .60$
§ 53. Survival of Action... 81 $\$ 54$. Cases of Malpractice. 82 $\S 55$. Liability for Accidents 84 $\S 56$. Special Liability..... 85 $\$ 57$. Burden of Proof.... 86 $\S 58$. Defenses ......... 87 $\S 59$. Liability for Operation 89 $\S 60$. Liability Under Enactments ........ 89

\section{CHAPTER V.}

CoMpensation.

§70. Employment U n d e r Contract .......99 91

\$ 71. Competency ....... 92

\$72. Right to Sue for Fees. 93

\$73. Illegal Practitioners.. 94

§74. Effect of Malpractice on Compensation... 95
\$75. Who Is Liable for Compensation .... 95

§ 76. Amount of Compensation ..............102

\$77. Use of Mails.........103

\$78. Liens ............103

\$79. Veterinarian a Bailee. 105 
\$ 80. Contract and Lien....10 107

$\$$ 81. Nature of a Lien....108

§ 82. Voiding a Lien......109

§83. Lien Not a Right to

Sell ............110

\$84. Actions for Recovery of Compensation...111

$\S 85$. The Veterinarian as a Witness ........114
$\S 86$. Duty to Prepare.....115

§87. Expert Testimony... 116 888. Definition and Scope of Expert Testimony ...........117

§89. Compensation as an

Expert .........120

\section{PART III.}

Pertaining to Governmental Control.

CHAPTER VI.

Governmental SERvices.

$\S$ 95. The Veterinarian as an Officer ........129

$\S 96$. Liability of Officers. 130

$\S 97$. Officers with Diseretion Cannot Be Coerced ...........133

$\S$ 98. Arbitrary Action Not Discretion .......134

§ 99. Authority Limited by Jurisdiction .....134

$\S 100$. Authority Determined by Legislation....137

$\S 101$. Invalid Act Is No Defense for Officer..137

$\S 102$. Quarantine .......138

$\S 103$. Quarantine Does Not

Depend upon Statute ............138

$\S 104$. Authority Canuot Be

Delegated ......139
$\S 105$. What Diseases Quarantinable .......140

$\S 106$. Methods in Quarantine ...........141

\$107. Quarantine Regulations Should Be Published .......143

$\S 108$. Diagnosis .........144 $\S 109$. Jurisdiction in Quarantine .........146

§110. Quarantine Versus Commerce .......149

$\S 111$. Destruction of Property ............151

$\S 112$. Personal Liability for Infectious Disease.151

§ 113. Law Versus Policy....153

$\S 114$. Appraisement .....157 $\S 115$. State and National Officers at Same Time .........159

\section{CHAPTER VII.}

\section{GOVERNMENTAL INSPECTION.}

$\S 120$. Work of Veterinarians .........163
$\S 121$. Methods of Governmental Control ...163 
DAIRY BUSINESS

$\$ 122$. Quality of Goods.... 166

$\S 123$. Dairy Inspection.... 167

$\S 124$. Confiscation ........173

$\S 125$. Veterinary Authority

in Milk Industry..174

$\S 126$. Dairy Products......174

\section{MEAT INDUSTRY}

$\S 127$. Transportation of Live Stock ..........175

$\S 128$. Departmental Veterinarians ........176

$\S 129$. General Quarantine Regulations ....176

$\$ 130$. Texas Cattle Fever..177

$\$ 131$. Protection of Inspectors ...........180

$\S 132$. Liability of the Department .......181

$\S 133$. Scabies .......... 182

\$134. Hog Cholera and

Swine Plague ....182

$\S 135$. Dourine .......... 182

$\S 136$. Lip and Leg Ulceration (Necrobacilliosis) $\ldots \ldots \ldots \ldots 183$

$\S 137$. Glanders . . . . . . . 183

$\S 138$. Tuberculosis .......183

$\S 139$. Foot and Mouth Disease ...........184
$\S 140$. Imported Animals...186 $\S 141$. Importations f r o m North America ...187

$\S 142$. Federal Supervision at Slaughterhouses 188

$\S 143$. Antemortem Examination ..........189

$\S 144$. Postmortem Exanination ...........189

$\S 145$. Condemnations ......190

$\S 146$. Sterilization .......195

$\S 147$. Disobeying Order's...195

$\S 148$. Arbitrariness .......195

$\$ 149$. Appeal ........... 196

$\S 150$. Prosecutions ..... 196

$\S 151$. Statutes ......... 196

$\S 152$. Meat Inspection. . . . 197

$\S 153$. Intrastate Meat Industries .........198

$\S 154$. Municipal Control...199

$\S 155$. State Regulation....200

$\S 156$. Common Law R'egulation .........200

\section{BIOLOGIC SUPERVISION}

$\S 157$. Biologic Products...201 $\S 158$. Governmental Responsibility .......201 $\S 159$. Evidence of Infection .........203

\section{CHAPTER VIII.}

Executive Organization.

\$165. American Executive System Unsatisfactory ..........206

$\S 166$. Executive Boards....207

$\S 167$. A Trained Executive 210

$\$ 168$. Paid Executives....211

$\S 169$. Permanency of Office. 212
$\S 170$. Veterinary Science and the Medical Profession ......212 $\S 171$. License Examiners. .214 $\S 172$. License Appeals.....216 $\S 173$. Health Preservation a Function of the State .........217 
\$174. Organization of a

$\S 176$. Records ........223

Health Department

- State .......219

$\S 175$. Local Organization..221

\$177. Reports .........223

\&178. Guidance of Legisla-

tion ..........224

\section{PART IV.}

Pertaining to Animals Generally.

CHAPTER IX.

\section{OWNERSHIP OF ANIMALS.}

$\S 185$. Wild or Domestic An-

imals .........229

\$186. Animals Ferae Natu-

rae ...........231

$\$ 187$. Dead Animals......231

\$188. Qualifications ......2232

\$ 189. Dogs ..........232

$\S 190$. Ornership of Animals

- How Obtained..234

$\S 191$. Estrays ........236

$\S 192$. Sale of Animals.....237

$\S 193$. Warranty of Soundness ..........239

$\S 194$. Illustrative Cases of Unsoundness ...242

$\S 195$. Warranty of Character .........244

$\S 196$. Bill of Sale........246

$\S 197$. Ownership of Increase ........247

$\S 198$. Proof of Ownership. 249

199. Marks and Brands..250
$\$ 200$. Sale of Brand.....252

$\$ 201$. Altering of Brand...253

$\S 202$. Wrongful Branding..254

$\S 203$. Driving from Range. 254

$\$ 204$. Breeding .........255

$\S 205$. Service Fees .......255

$\S 206$. Warranty of Sound

Heredity .......256

$\$ 207$. Insurance of Get. ...257

$\$ 208$. Liens for Service....258

$\S 209$. Liability of Owner of Stallion ........259

$\S 210$. Gelding a Stallion...259

$\S 211$. Liability of Owners of Animals ......260

$\S 212$. O blig a ti o n to Restrain Animals....262

$\S 213$. Barbed Wire Fences.265

\$214. Frightening Animals.266

$\$ 215$. Liability for Injuries on the Public Highway $\ldots \ldots \ldots 266$

\section{CHAPTER $\mathrm{X}$.}

\section{BAILMENT.}

$\S 220$. Definition ........268

$\$ 221$. Bailment a Contract. 269

$\S 222$. Bailer May Not Be

Owner .........269

$\S 223$. B a ilm e n t Implies Knowledge of the Bailee .........270
$\S 224$. Care Required of Bailee ...........270

$\S 225$. Ordinary Care .....272 $\S 226$. Duty of Bailor.....272 $\S 227$. Liability of Bailee. . 273 $\$ 228$. Warranty of Bailor..275 
$\S 229$. Bailment, $\mathrm{S}$ a l e, or Gift .........276

$\S 230$. Bailee's Right to Use Property Bailed...277

$\S 231$. Actions for Liability of Bailee ......278

$\S 232$. Conversion .......279

$\S 233$. Liens ...........280

$\S 234$. General Liens .......281

$\S 235$. Agister's Lien ......283
$\S 236$. Trainer's Lien ......285

$\S 237$. Priority of Right....285

$\S 238$. Right of Sale......286

$\S 239$. Estrays and Trespassing Animals ....287

$\S 240$. Waiver of Lien.....289 $\S 241$. Illegal Sale by Bailee.289 $\S 242$. Lien Once Lost Can Not Be Revived...290

Index of Cases Cited.....................291

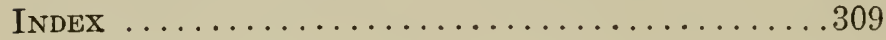




\section{PART I \\ PERTAINING TO LEGAL PRINCIPLES}





\section{ESSENTIALS OF VETERINARY LAW}

CHAPTER I.

GENERAL PRINCIPLES.

$\S 1$. Importance of Funda- $\S 6$. Municipal Ordinanees. mental Prineiples.

$\S 7$. Judicial Legislation.

§ 2. Common Law; Constitutions; Statutes.

\$ 3. Nation, State, or City.

$\$$ 4. Division of Powers.

$\S 5$. Executive Orders, Law?

\&. Acts Must Not Be Arbitrary.

$\S$ 9. Duties and Powers Cannot Be Delegated.

$\S 10$. Judicial Decisions.

1. Importance of Fundamental Principles. Before a man would buy an apartment building in Chicago, for example, he would enquire what kind of a title the seller held, and from what source, what claims there were against the property, and what special obligations he would assume in purchasing it. In a similar way, in order to fully appreciate legal points it is needful to consider the source of the law indicated, and the nature of the authority involved. The provisions of a city ordinance may be set aside at any time, or even rerersed, by the action of the state legislative body, or by that of the nation. Authorities of the state may take adjoining buildings for the benefit of the public. The one taken under the power called eminent domain must be paid for at a fair price; the 
one taken under police power may be destroyed, without any obligation on the part of any one to pay for it. Two veterinarians treating the animals on adjoining farms in the same way may both lose their patients. One might be held legally liable for the value of the animal lost, and the other not liable, depending upon the underlying principle of his legal obligation.

\section{Common Law; Constitutions; Statutes. Many} people imagine that if they know the statutes which have been enacted upon a certain point, they know all of the law necessary relative thereto. The fact is that there is a great body of the law which is not written in any statute, and it is this "Common law" which gives to English speaking nations a peculiar system. It is evident that it would be a practical impossibility to cover all possible points with enactments, and in fact it would frequently be undesirable so to do. Through the decisions of the English and American courts there have gradually been evolved certain principles of law which find their use to a greater or less degree in almost all legal decisions. This body of principles is known as the common law.

There are certain principles which have been adopted by the nation, and others by the separate states, and which have been put in definite form in words, and these documents are known as constitutions. They are so arranged that they are not easily changed. They are the charters under which the national and state governments work. No city ordinance, no executive order, no state statute is really law and binding, if it violate the principles of the constitution of its state, or of the 
nation. For example: There is in the Revised Statutes of Illinois an act prohibiting the importation of Texas cattle into the state from the first day of March to the first day of October. This law, originally passed in 1867, was intended to prevent the spread of the Texas cattle fever. A similar law in Missouri was pronounced unconstitutional by the Supreme Cour't of the United States because it violated the right of Congress over interstate commerce. ${ }^{1}$ Since then the Illinois court has similarly decided that the Illinois statute is unconstitutional also. ${ }^{2}$ This act should have been repealed by the legislature. It remains as one of the old curiosities. It is not law, though it has the appearance of being such.

Statutes are enactments made by the legislative body having jurisdiction. The field for statutes is such subjects as need a definite settlement, but the decision relative to which may need to be revised. The statute must not violate constitutional provisions. Otherwise, so long as the law stands, whatever it commands must be done, and it must be done in the way it is thus ordered. The Texas law ordered that a butcher must report to the County Commissioner's Court at each term the number and description of all cattle slaughtered by him since the last report. The fact that a butcher presented such a report, duly made out and sworn to, at a subsequent term did not excuse his failure to comply with the law. ${ }^{3}$

1 H. \& St. J. R. R. Co. v. Husen, 5 Otto, 465.

2 Salzenstein v. Maris, 91 Ill. 391; C. \& A. R. R. Co. v.
Erickson, 91 Ill. 613; Jarvis v. Riggin, 94 Ill. 164.

3 Bruns r. State, 33 Tex. Cr. 415,26 S. W. 722. 
What a statute expressly provides is legal, but the permissions of the statute must not be presumed to extend beyond the plain meaning of the words. In Massachusetts there was a statute which gave permission for any person to kill a dog wandering around without a collar. That law did not make such lack of collar sufficient evidence of lack of ownership to justify one in taking the dog for his own use. ${ }^{4}$ The permission to kill was based upon the idea that the dog would not be killed unless he were a nuisance. If he had ralue, the person taking him would be depriving another of his property for his own use; that is stealing. ${ }^{5}$

3. Nation, State, or City. In the United States we find different governmental entities, with their appropriate organizations, and with sometimes conflicting authority. The Constitution of the United States gives to Congress exclusive legislative power over certain subjects, and concurrent jurisdiction over certain others. Where Congress has exclusive authority the states must not intrude. Where the jurisdiction is concurrent, the enactments of the state will be respected, only in so far as they do not conflict with Congressional action. By the express provision of the Constitution of the nation, all power not expressly given to the Congress, or prohibited to the states, is reserved to the individual states. The nation was made up from a union of states. This is not at all the relationship of the state and the towns or cities. The state is not composed of towns and cities, nor of counties. The counties, torns and

$$
4 \text { Cummings v. Perham, } 1: \text { "Public Heslti, Chap. II. }
$$
Mass, .5.). 
cities are parts of the state, and they have only such power and authority as the state may give to them; or as may be reasonably implied in the powers expressly given. There are many things which it might be desirable for a city to do, but which it cannot do until it shall be given such power by the state. ${ }^{6}$ A power or authority given to the cities may at any time be taken back by the state legislature, and ordinances previously passed and in force under such authority will thus be repealed. ${ }^{\top}$

4. Division of Powers. According to the American governmental system, and more or less definitely and expressly provided in the several constitutions, the powers of gorermment are divided between three branches. The legislature has authority to make laws, but not to interpret nor to apply them. The business of the executive branch is solely to administer the laws impartially. It is necessary for the executive often to interpret the laws for his own guidance, but his interpretation has no weight of "authority." It is true that being in a position to know the facts, the opinion of the executive may be given respect, but his interpretation is frequently set aside. Neither is it the province of the executive to say what shall, or shall not, be the law, further than that under the veto power he may impede the passage of certain acts which he thinks prejudicial; but eren then the acts may be made law over his veto. ${ }^{8}$

6 Jenkins v. Board of Education, 234 Ill. 422.

i Public Health, Chap. IX.
8 Public Health, Chapters III, IV, V. 
The courts only may give an authoritative interpretation of the laws in their application.

This division of powers is far more important than is generally recognized. It is the chief defense against oppression and tyranny. If the legislature were permitted to interpret their own laws they might easily make that a crime which when committed was really no crime. If the executive were permitted with impunity to make laws as he pleased, and to interpret laws enacted according to his own will, he could easily prove himself a dangerous tyrant. If the majority of the voters be permitted to do as they please in the making and enforcing of the laws, we should find the worst form of tyranny-that of the mob, such as brought horror, death, and ruin upon so many innocent victims under the old Paris Commune. Every attempt at such unconstitutional union of powers in one person, or in one govermmental body, is a move towards the state of affairs most perfectly represented by the Paris Commune. It may do no harm for a governor to attempt to force through certain legislation, further than it is a usurpation of authority, and it tends to break down the barrier. Congress, or a state legislature may attempt to force the President, or the governor, to certain executive action against his judgment, by withholding appropriations until he does as the legislative body demands, but such action is a violation of constitutional provisions which should be observed. It is the duty of the executive to enforce the laws as enacted. That is a different matter. What the law directs he should do. If he be given discretion, he must use his 
own judgment, and should not be forced by the wish of those who are not responsible for his duties. If he fails to enforce the laws as enacted, he may be impeached and removed from office.

5. Executive Orders, Law? It very frequently happens that a statute needs to be supplemented by definite regulations in application. When these regulations are within the provisions of the statute, they have the full force of the original statute, and are equally binding. This has given rise to the statement often made that executive orders have the force of law; but this statement is not always true. The executive orders must simply provide for the working of the statute as enacted, and must not attempt to enlarge the scope or meaning of the act. For example: Some years ago Congress passed an act providing for the admission of animals intended for breeding purposes, free of duty. The Secretary of the Treasury, whose duty it is to supervise the collection of import duties, made a ruling that animals so admitted free must show evidence of superior breeding. This was probably the intention of the Congress in making this exception, as without such a reservation it would be an easy matter for one to bring over any animal free if it had the power of reproduction. However, Congress failed to make this statement in the act, and the court very properly said that the Secretary's regulation appended to the provisions of the statute another restriction. It was therefore not a regulation, but new legislation, and was therefore a violation of the principle of division of powers $(\S 4)$ and so 
unconstitutional. ${ }^{2}$ Similarly, regulations as to manufacture were considered to be legislation, and so not law. ${ }^{10}$ But regulations relative to marking of goods were considered true regulations, and not additional legislation." "As regulations depend mpon a statute, they can never go to the extent of being independent of the statute. A regulation which is in effect legislation is in a just sense a regulation no longer. That is, as a regulation is derivative, it must keep within the scope of the statute under which it is formed." 12

This point is very important for veterinarians for two reasons. First, many members of the profession hold administrative positions, and as such it is their duty to apply the laws enacted. Through mistaken icleas of their authority they often attempt this excess of power, and if they do so to the injury of any one, they may be held liable for such damages as may appear. Secondly, veterinarians are working moler the law, and they may be met with attempts at illegal use of official positions in a way that may work injury to themselves or to their clients. If, in such cases they know the general principles of the legal situation, they may save themselves and their clients trouble and money. ${ }^{13}$

6. Municipal Ordinances. Although municipal ordinances, and sometimes the regulations of boards of health, may have the form of enact-

9 Morrill v. Jones, 106 U. S. 466.

${ }_{10}$ United States v. Eaton, 144 U. S. 677 .

11 In re Kollock, $165 \mathrm{U}$. S. 526.

$12 \mathrm{~W}$ y m a n. Administrative Law, 133.

13 Public Health, 100. 
ments, they are really essentially executive orders and regulations. The city has no authority to make ordinances outside of the limits of the provisions expressly given in the charter and state statutes. Neither may the city pass an ordinance which has a legal authority outside of the limits of the city, except in a few special cases where such additional authority is given, such as to protect the purity of the public water supply. A city may pass an ordinance prohibiting the importation of milk which comes from cows which have not passed the tuberculin test. This ordinance has no legal authority over the dairy situated outside of the city, though it may have a commercial force over a dairy situated even in another state. The farmer is not compelled to use the tuberculin test; but if he wishes to sell his product he must furnish such a product as his customers want, and unless there be some special restriction in the matter, such as was enacted by the state of Illinois a few years ago at the demand of the dairymen, a city may make such a regulation by ordinance, and the ordinance will be supported by the courts. ${ }^{14}$ The city may not go beyond the provisions of its charter and the statutes, but whatever the state expressly provides it may do legally. ${ }^{15}$

Those who are familiar with European methods sometimes fail to realize the fundamental differences in the systems of government. There the separation of porrers is not distinct, and we find

14 Adams v. Milwaukee, 228

U. S. 572 ; Adams v. Milwaukee, 144 Wis. 371; Nelson v. Minneapolis, 112 Minn. 16; Borden v. Board of Health,
Nontclair, 81 N. J. L. 218, 80 Atl. 30; Hawkins v. Hoye (Miss.), 66 So. 741. 15 Public Health, 254-262. 
the executives performing much of the duty which here must be performed by the legislative body or the court.

7. Judicial Legislation. We sometimes hear of laws made by the courts. It is true that sometimes the interpretation of a law made by the legislature either adds to, or takes from, the purpose of the framers; but the court does not make the law. It is the business of the courts to interpret the laws made. The court may doubt the advisability of the law, or the necessity for its passage; it may think that some other provision would be better; and the judge may be personally opposed to the enactment; but if the letter of the law seems reasonable, and in harmony with the constitution, and if the legislative body has not exceeded its authority, it is the business of the court to uphold the statute, and to put upon it the simplest possible construction, according to the form of words used. ${ }^{16}$ "A statute will not be declared unconstitutional unless its invalidity appears beyond a reasonable doubt." ${ }_{17}$ In a recent case in New York, where a muzzling ordinance was being attacked, the argument was made that "The court will probably have little difficulty in conceiving of situations where the proper use of a leash, or of some form of closed conveyance could secure perfect protection to the public." The court answered: "This argument, however, entirely begs the real question. The court has nothing to do with the wisdom of the ordinance; perhaps a less sweeping ordinance would effect the same

10 State v. K. C. M. \& B. Co. (Ark.), 174 S. W. 248.
17 State ex rel. Christian Co. v. Gordon (Mo.), $176 \mathrm{~S}$. W. 1. 
result; perhaps there are conditions where a proper use of a leash would secure perfect protection to the public. *** Under the circumstances it seems to me quite illogical to urge that the ordinance bears no reasonable and direct relation to its purpose. Consequently the court must hold that it comes fairly within the power of the board of health, even though the court might feel, which it by no means desires to intimate, that it might have found other means less annoying to dog owners which might prove equally effective. * * * It is the duty of the court to give an ordinance, where possible, such construction as would not render it unconstitutional." 18

It is also the duty of the courts to prevent excess of other officers, to see that they do what is required of them by law, and that they do their work in proper form. It is their duty also to judge between man and man, and to punish evildoers. ${ }^{19}$

8. Acts Must Not Be Arbitrary. Arbitrary action is the result of will, rather than of reason. It is the method used by tyrants in government, whether the tyranny may be shown by a single king, or by a temporary majority of the people. For this reason even the semblance of arbitrariness is shunned in American governments. The executive officer must show reason in the application of the law, and he must not use his position for the purpose of gaining some personal advantage over another. So the wording of a statute or ordinance must show that it is based upon a

18 People ex rel. Knoblauch v. Warden of City Prison, $153 \mathrm{~N}$.

19 Public Health, Chap. V.

Y. Sup. 463. 
reasonable interpretation of facts. Long ago the Supreme Court of the United States showed that a statute prohibiting the sale of meat unless it shall have been inspected on the hoof within the state, though on its face it may appear to be a sanitary measure, is really an unnecessary restraint upon interstate trade. ${ }^{20}$ In other words, the measures adopted for safeguarding the health were unnecessarily strict, and therefore they were unreasonable. At about the same time the states of Missouri and Texas passed acts which were intended to aid in the control of the Texas cattle fever. The Texas act prohibited importation of cattle from infected territory, and the U. S. Supreme Court upheld this as reasonable. ${ }^{21}$ The Missouri statute, as does also that in Illinois, absolutely prohibited the importation of cattle from a certain section during certain months of the year. There was nothing in the law which prevented the importation of cattle from other sections which might be infected, nor was there any exception made as to a section in the prescribed territory where there might be none of the fever found. It was an arbitrary prohibition of the importation of cattle from a certain district. It was an interference with interstate traffic, and not really a health measure. The Supreme Court therefore held it unconstitutional. ${ }^{22}$

Cities, in their passage of ordinances, are very prone to attempt this violation of rights. In the granting of exclusive rights and franchises the

20 Minnesota v. Barber, 136

U. S. 313 .

22 H. \& St. J. R. R. Co. $\nabla$.

21 Smith r. St. Louis \& S. W.

R. Co., 181 U. S. 248. 
city is very likely to be arbitrary rather than reasonable. Unfortunately, health executives are frequent violators of this safeguard, and they are impatient of any opposition. To order that all the garbage for collection be placed in tightly covered cans of a certain general size and character may be reasonable, but to specify a particular make of can, thus giving to that manufacturer a monopoly, would be considered unreasonable. In a populous city where the manure is carted away for miles, and has practically no commercial value, under certain circumstances the courts would uphold a contract made with some man or corporation by which the said man or corporation agrees to haul away all garbage, manure and dead animals, and by which the city gives these substances to the contractor. On the other hand, in a small place where the garbage and manure question is not important, and where the owners make use of the materials upon their own places, such a contract would be considered arbitrary, unreasonable and illegal. Cities in the borderland between these two are the ones where the question is most likely to arise, and it is here that those working honestly for the common good are most likely to misinterpret the meaning of the court..23

9. Duties and Powers Cannot Be Delegated. The law makes a difference between what it calls ministerial and discretionary duties and powers. This distinction runs through private and public life. A ministerial office or employment is one in which the work is essentially largely mechanical. A discretionary position is one which demands

23 Pubidc Health, 195, 259. 
judgment. In official life, ministerial duties are exactly prescribed by law; and the officer or employee must do all that the law says, in the way that it demands, and no more. In discretionary positions the officer must decide his own course of action to no small degree. When a veterinary surgeon is engaged to look after the condition of stock which a man is about to buy, it is to be presumed that it is because the employer desires the professional judgment of the veterinarian. Having employed this veterinarian it would not be a fair deal for the surgeon to send someone else in his place (unless the substitution were previously agreed upon with the employer), and if such a substitute be sent the employer would not be liable for the payment of the substitute. He would not be liable for the fee of the man employed, for the man employed did not, in the case supposed, perform the duty imposed in the contract. He would not be obligated to the substitute for he had no contract, either expressed or implied, with him. So where a physician was employed to treat the sick of the community, he conld not collect for the services of a substitute, nor could the substitute collect directly. ${ }^{24}$ It follows also that an officer whose duties require the use of judgment cannot leave the performance of them to a substitute. ${ }^{25}$ Where the duties are purely ministerial, like the writing of a license, the duties may be performed by another.

24 Chapman v. Muskegon Co..

25 PUbLic HeALth, 328, 272.

169 Mich. 10, 134 N. W. 1025;

Hickman v. Mellorris, $149 \mathrm{Ky}$.

1, 147 S. W. 768. 
10. Judicial Decisions. Inasmuch as legal discussions and text-books deal chiefly with the reports of judicial decisions, it is necessary to clearly understand what is meant. Discussions of statutes, irrespective of decisions, are of very little practical value, for statutes are often changed as fast as they are made; and one illegal statute frequently begets several others equally vicious before its harmful course is checked by a judicial condemnation. On the other hand, the same court may give seemingly conflicting decisions relative to the same general point, because the statute has been changed in the meantime by the legislature; yet the decisions are really harmonious, because the outcome of the same principle. Though in some states there are provisions for getting an opinion from the court without having a case before it, such conditions are uncommon, and the opinion thus rendered may be inconclusive. To get a valuable decision there should be a full consideration of all sides, and this is practically impossible unless the various positions shall be argued. This happens when a "case" is before the court. But the case is generally heard originally before a judge in one of the lower courts. His duty is more particularly to apply the law to the individual matter before him. His attention is directed especially to the facts, rather than to legal interpretation, and when he renders his decision he is very likely to be unconsciously biased by personal feelings, or by the surroundings. The decisions in these lower courts are seldom published, and they are of relatively little value. 
When there is a question as to the interpretation of the law, or to use a legal phrase, when there is a question as to points of law, the case may be appealed. The matter is then presented to an appellate, or to a supreme court. Here the matter is heard before from three to twelve judges who give their attention to the questions of law, rather than questions of fact. If the decision in the appellate court is still unsatisfactory to one of the parties, the case goes to the supreme court. The decision of a state supreme court is conclusive as to the law of that state, except in so far as a question of national law may be involved. These appellate and supreme court decisions are generally published, and it is to these that "citations" are made. Where the members of the higher court do not agree, this fact is stated, with the opinion of the dissenting judges, in many cases. The decisions or opinions are discussions of the points of law involved, and depend largely upon previous decisions on similar points, and they serve as precedents for future decisions.

There are three factors which tend to prevent appeal. The points or value involved may be of insufficient consequence; or, the person dissatisfied may be financially unable; or, the parties may be satisfied that the case has really been decided by some previous decision.

The veterinary profession is a part of the general medical profession. As a profession it is as yet "in short dresses." The number of real veterinarians is small, relatively, and there are as yet few states in which there has been an attempt to regulate the practice. In contrast, the gen- 
eral medical profession is old, it is crowded, it has been generally regulated, and in addition it lends itself to certain kinds of question which would hardly be applied in veterinary practice (such as, Is faith cure "the practice of medicine?"). The consequence is that almost all the legal points have been considered with reference to the general profession, and there are relatively very few "reported" cases relative to veterinary practice. The cases reported in the papers, as a rule, are not legally "reported cases," and they have of themselves practically no value as precedents. They are simply verdicts in lower courts, and if appealed they might be reversed by the higher court. They are therefore very unsafe to depend upon. They are not properly judicial decisions, but so far as the law is concerned they are simply the opinions of one man in each case; and that one man may be thoroughly incompetent, in spite of the fact that he may hare been elected to his position by a majority of his neighbors for friendly reasons.

It therefore follows, that in seeking for the legal principles applicable in the practice of the veterinary profession we may display few cases in which a veterinarian was involved, but we must depend upon similar cases in other lines. 


\section{CHAPTER II.}

POLICE POWER, "DUE PROCESS," AND NUISANCES.

\$11. Definition of Police Power.

\$12. Police Power Resides in the States.

\$13. Alienum Non Lacdat.

\$14. Police Power Is Abore Private Rights.

\$ 15. Police Power Cannot Be Alienated.

\$16. No Property Right in Articles Acquired or Used Contrary to Law.
$\S 18$. Nuisance.

§ 19. Nuisance Per Sc, and In Posse.

$\S 20$. Nuisance a Question of Fact.

$\S$ 21. Changes in Legal Nuisance.

$\S 2$ 2. Treatment of Nuisances.

$\S 23$. City Must Not Commit Nuisance.

§ 24. Authority for Abatement, Not for Construction.

\& 17. Due Process of Law.

11. Definition of Police Power. Governments use various powers, such as that of taxation, treaty making, control of commerce, etc., but the one which most concerns members of the medical and surgical professions is embraced under the somewhat indefinite term of "police power." 1 This power is by no means confined to the use of the officers whom we call "police." Much of their duty pertains to the enforcement of the criminal law, from which police porrer is quite distinet. Police power is that inherent power in governments which is used for self protection. It tends to prevent misfortunes and calamities, and it works largely by placing restrictions upon undue liberty of action on the part of citizens. An exact definition of the limits of the power has never 1 Public Health, Chap. Vi. 
been given, and the general principles under which it operates may cause expansion or contraction of its application upon the same general subject under different circumstances. To prevent harm being done by unqualified or unprincipled practitioners of medicine or surgery, under police power the doctor may be compelled to present evidence of his fitness for the trust, and in order to carry out this provision the state may prohibit any person from attempting to treat the sick or injured animals of any species until he shall first have obtained a license. Under police power quarantines are established, the production and sale of foods are regulated, industrial enterprises are supervised, the construction of buildings is controlled, the breeding of flies, mosquitoes, rats and other pests is restricted, and trade operations are watched to prevent fraud. Under this power statutes are enacted by the state, and ordinances by the city. Sometimes it is exerted by an executive officer unsupported by any previous legislation, and it is recognized by the courts. It is a tremendous power, which may easily be abused, but its existence and recognition is of the utmost importance for the general good.

12. Police Power Resides in the States. The Ninth and Tenth Amendments to the Federal Constitution have generally been interpreted as granting to the individual states the exclusive right to use the police power, and under state regulation this power has been exercised by the towns and cities within its border. Under that interpretation the nation has no authority to exert this power within the different states. Practically the 
nation has frequently obtained the same result by the use of other powers, or through moral influence. For example: Though Congress may not have the power to determine the conditions under which veterinarians shall be permitted to practice their profession in the several states, the object may be obtained indirectly. Under the provision giving to Congress exclusive control over interstate and foreign commerce, laws have been passed giving to the Department of Agriculture the supervision of the meat industry and the transportation of animals. It is necessary for the Department to employ many veterinarians, and it may refuse to consider the application of candidates who have not graduated from colleges of a certain prescribed standard. This forces all the colleges to that standard. Further, the Department may refuse, under suitable laws, to permit live stock to pass from one state to another unless accompanied by a certificate from a veterinarian of approved standing. Neither of these provisions would have influence upon the right of a man to practice his profession in a given state, except inclirectly. This right of regulation, depending as it does upon police power, has always been interpreted as belonging to the individual states. For this reason there would be great difficulty in arranging for such a license as would be operable in all the states. The number of fully qualified veterinarians is not relatively great. Most of the present practitioners might not find it difficult to pass the test which might be required of them should they attempt to more into another state. There is in this condition a practical guaranty 
that a man fully equipped according to modern standards would gain admission to practice where he chose. The medical profession is overcrowded, and the consequent difficulty in obtaining reciprocal licenses has resulted in schemes for getting around the present condition by making all state boards recognize the authority of some national board. This condition may arise in the veterinary profession. According to past decisions such an arrangement is constitutionally impossible.

13. Alienum Non Laedat. There is an old principle of the common law which is very powerful, even at the present time in spite of its age, which is known legally as alienum tuum non laedat; this means that a person may so enjoy the use of his own property that it shall work no injury to another. This is one of the principles of the police power which plays an important part in laws, ordinances, and executive action, as well as in court trials. A man may own a lot in town upon which he seeks to build a livery stable, or to erect a veterinary hospital. He may have actually spent a large amount of money in erecting the building and putting in the equipment. There may be no statute or ordinance prohibiting such use of the building, and he may have had the approval of his plans by the city building inspectors. All these things may be true, and still before he attempts to use his building for the purpose intended he may be checked by an injunction. The Massachusetts court held that it is not necessary for the board of health to wait until a nuisance has actually occurred before getting an injunction 
against the operation of a livery stable. ${ }^{2}$ A man may burn the refuse upon his place, but if that burning endangers his neighbor's property he may not lawfully so burn it, even though there be no enacted statute or ordinance prohibiting such burning. Such a bonfire would violate this principle of the common law, and if he persisted in burning his rubbish, and his neighbor's property should be burned, he would be liable in civil damages for the value of the property destroyed, and for other injuries sustained, because he violated this principle. So, if a man has a vicious dog, and he permits the dog to run in the street, he is not so using his own property as to protect others from being injured. If a man sells diseased meat for food, and the purchaser should sustain injury therefrom, he would be liable in civil damages. A man must not use his property in such a way that it will work injury to his neighbor.

It will be found that this principle lies at the root of a large proportion of the present discussion, though its relation thereto may not always be clearly mentioned.

14. Police Power Is Above Private Rights. It is evident from the foregoing that the police power of the state, perhaps as represented by the city, is superior to private rights. Under police power property may be seized when it is a danger to the community. Thus it frequently happens that meat may be seized, and even destroyed, without giving to the owner any compensation, even though there may be some value therein, aside

2 Board of Health v. Tupper, 210 Mass. 378,96 N. E. 1096. 
from its value as food. ( $\$ 111$.$) Houses may be$ destroyed. In all these matters it is presumed that the owner as well as others will be benefited. Under police power it may be possible to take possession of a house and use it as a hospital, and without rendering any compensation, in the absence of special statutes covering the subject. A man's horse may thus be taken from him temporarily. If property be taken under what is called eminent domain, it must be paid for. This shows how easy it might be to be unjust under police power unless certain checks be observed.

In Bacon v. Walker ${ }^{3}$ the Supreme Court said, in speaking of police power, that the power of the state "is not confined as me have said to the suppression of what is offensive, disorderly, or insanitary. It extends to so dealing with the conditions which exist in the state as to bring out of them the greatest welfare of the people."

15. Police Power Cannot be Alienated. Police power always resides in the state. It may regulate the sale of liquor, by the granting of a license, or it may grant to a veterinarian the right to practice his profession, but in neither case does it grant to the party interested an absolute right, and free from control. The license may at any time be revoked upon showing sufficient cause. The state does not give away, nor sell, its right of control under police power. The power is necessary for the protection of the state and its citizens. It may suspend its control under certain conditions, but it still preserves its right to reassume full responsibility. Under this power the state may abso-

3204 U. S. 311. 
lutely prohibit, or it may supervise and regulate a condition or a thing so far as it may seem to be necessary for the good of the public. The laws of New York give to the board of aldermen of the city of New York authority to pass ordinances regulating the keeping of dogs; and to the board of health power is given to publish additional provisions for the security of life and health in the city of New York, not inconsistent with the constitution and laws of the state. The city did make an ordinance regulating the presence of dogs upon the streets and in public places. Thereafter the board of health published an additional regulation requiring muzzling, and the action of the board of health was attacked on the ground that the power of the city having once been exercised in the ordinance passed by the aldermen, the board of health could not make additional regulation of the subject The court held that such a construction would so seriously interfere with the jurisdiction of the board of health as to make its power to pass health regulations very difficult, and the public health would thus lack the protection desired. ${ }^{4}$ In other words, whenever the state or city grants certain privileges, it does so with the implied understanding that the parties favored will not use their privileges to the injury of others. Neither city nor state will permit a nuisance.

16. No Property Right in Articles Acquired or Used Contrary to Law. There is no property right in things made, acquired or used contrary

4 People ex rel. Knoblauch v. Warden of City Prison, $153 \mathrm{~N}$.

Y. Sup. 463. 
to law. Thus, a building erected contrary to law may be pulled down; ${ }^{5}$ but the material of which it was constructed must be saved for the owner, according to some decisions, for it was presumably honestly acquired. Game unlawfully killed may be destroyed.

17. Due Process of Law. By the Fifth and Fifteenth Amendments to the national Constitution, it is provided that property or liberty shall not be interfered with without due process of law. Essentially this means that the party interested shall be notified, and have an opportunity for hearing and defense. If this hearing shall not have occurred before the thing has been taken, the owner has his opportunity to be heard afterward. The burden then falls upon the officer who has taken the property to show that his taking of it, and perhaps his destruction of it, was lawful and necessary. If he cannot so prove, he will be consiclered as having acted unlawfully. Since the laws presume that officers always act lawfully, it is considered that though he may hold an office, in that case he acted as a private wrongdoer, and so is personally liable for his misdeed. ${ }^{6}$ Thus, when a board of health in Massachusetts ordered the killing of a horse for glanders, and the court decided that the evidence did not show that the horse was in fact suffering from that disease, the members of the board were forced to respond in damages. $^{7}$ It is very evident that it would be

5 Eichenlaub $\nabla$. St. Joseph, 113 Mo. 395, 18 L. R. A. 590; King v. Davenport, 98 Ill. 305; Hine v. New Haven, 40 Conn. 478.
6 Public Health, 273, 364366.

i Miller v. Horton, 152 Mass. 540. 
easier to prove the existence of the disease before the horse was destroyed than it would be afterward.

Due process does not necessarily mean that there must be a trial in court. The same object may be secured throngh a hearing before an executive officer, or it may be secured beforehand by the passage of a statute or ordinance. It is presumed that while the enactment is pending it may be attacked, or after its passage any one desiring to do so may then attack it in court. The courts will not permit arbitrary action. ${ }^{8}$

18. Nuisance. The basis of almost all public health operations is found in the law of nuisance. A nuisance is a thing or condition which tends to work an injury, either to a limited number of individuals, or to the community. If it endangers the public it is called a public nuisance. If it endangers only a few persons it is regarded as a private nuisance. The remedy for private muisances is found in eivil suits. That for a public nuisance must be found either in a civil suit, a criminal prosecution, or in executive action. An infectious disease is a nuisance, and therefore it is customary to institute a quarantine. This is done under the police power. A rabid dog is a nuisance, and because the dog is thus rendered useless, and valueless, he is ordinarily killed. Property misused, as for a house of ill fame, or for the illegal selling of liquor, is a nuisance. The owner may be punished criminally, and further misuse may be prevented by an injunction. A man possessing

8 Public Health, Chap. ViI, and 273 . 
an animal infected with a communicable disease may be assessed damages by a court if through his negligence the disease spreads to other animals of his neighbors. ${ }^{9}$

19. Nuisance Per Se, and In Posse. A nuisance per se is one which is essentially a nuisance. A mad dog is such a nuisance. It should be abated without question. A nuisance in posse is one which may be a nuisance according to circumstances. A manure pile has a commercial value in some communities, and it may exist without endangering any person or property. When it is located in a city, and is so maintained as to breed flies and rats, it becomes in fact or in esse a nuisance, and as such should be abated. A rat is always a nuisance per se, and should be exterminated. An animal infected with a communicable disease which is curable is a nuisance, but not one per se. As such it may properly be so guarded as to prevent the spread of the disease, but the officer would not be justified in ordering its destruction, unless its value were insignificant as compared with the expense of quarantine. Because a nuisance per se is a public danger, it has no value, and there can be no property right therein. A nuisance in posse has a value oftentimes, and there may be a property right therein which must be respected. The building used for an illicit liquor traffic is a nuisance in esse; that is as used it is a nuisance, but the nuisance is not in the building itself, but in its use. The building may be put to other uses, and on that ground the court might not justify its destruction.

9 Public Health, Chap. VIII. 
20. Nuisance a Question of Fact. The question of nuisance is one of fact, not of statute nor of opinion. ${ }^{10}$ To declare a thing a nuisance does not make it so; and this is true whether the declaration be made by an executive officer, or by the legislative body. In other words, a declaration that a thing is a nuisance must be capable of proof, by showing that the thing or condition either actually does produce harm, or is likely to do so. The Supreme Cour't said: ${ }^{11}$ "It is a doctrine not to be tolerated in this country, that a municipal corporation without any general laws, either of the city or of the state within which a given structure can be shown to be a nuisance, can, by its mere declaration that it is one, subject it to removal by any person supposed to be aggrieved, or even by the city itself. This would place every house, every business, and all property in the city at the uncontrolled will of the temporary local authorities." In a similar way the supreme court of Oregon emplasized the question of fact. The charter of the city conferred upon the municipality the power to declare what shall constitute a nuisance, as is very common in all states, but the court said: "12 "An ordinance cannot transform into a nuisance an act or thing not treated as such by the statutory or common law." Whether the declaration of a thing or condition or act to be a nuisance be made by the legislative, executive, or judicial branch of govermment, it is presumed that the determination has been reached by a species of judicial investi-

10 Public Health, 201.

11 Yates v. Milwaukee, 10 Wall. 497 .
12 Grossman v. Oakland, 36

L. R. A. 593, 30 Ore. $47 \mathrm{~S}, 41$ Pac. 5. 
gation of the facts, and that it is not the result of either prejudice or emotion. While a city cannot by ordinance make that to be a nuisance which is not such in fact, where there is an honest difference of opinion the determination of the community as expressed in a city ordinance is generally held to be conclusive for that community. ${ }^{13}$ A resolution of a board of health declaring that certain property is a nuisance is not a judicial determination of the question, and its opinion thus expressed is subject to determination by the court. ${ }^{14}$

Ordinarily legislative determination is held to be conclusive as to whether or not a thing or condition shall be deemed a nuisance; but this is not always so. If the legislature anthorizes an act to be done which withont the statute would constitute a public nuisance, such an act is thereby made lawful, and cannot legally be considered a nuisance, unless the legislature exceeded its authority, since a public nuisance per se cannot be lawful. ${ }^{15}$ Just as the declaring that to be a nuisance does not make it so when it is not a nuisance in fact, so, conversely, for the legislature or city council to declare a thing not to be a nuisance when it is really a nuisance, does not protect the owner or doer of the act in continuing thus to injure or endanger others. In granting a permit, as for the maintenance of a factory, it is presumed that the business will be so conducted as not to create a nuisance. It is hardly to be presumed that legis-

13 Bushnell v. C., B. \& Q. R. R. Co., 259 Ill. 391.

14 Gaines v. Waters, 64 Ark.
15 Sopher v. State, 169 Ind. 177,81 N. E. 913. 609. 
lators are so well posted as to the possibilities of a certain manufacture that they may know that it cannot be so conducted as not to create a nuisance.

A theatre is not a nuisance per se, and a declaration of a city would not make it so, unless it were in fact a nuisance. ${ }^{16}$ It is only when it is conducted in an improper manner, as to plays produced, or as to the structure of the building, or its maintenance, that it could be generally considered a nuisance. It is a nuisance if it be not furnished with proper exits, or if it be improperly ventilated, or if the aisles be narrow and permitted to be filled; for in these cases human life is endangered. It may be a nuisance by reason of its detrimental effects upon the morals, especially of children, if the plays produced be of objectionable moral teaching.

A large number of hogs kept on property adjacent to a city, so that odors therefrom were offensive to people living in the neighborhood, and to those who passed along the streets, and impaired the health of the citizens and diminished the value of their property, was found to be a public nuisance by the Kansas supreme court, which held that it should be perpetually enjoined. ${ }^{17}$ The maintenance of a hog ranch where garbage, etc., is to be fed may be at the same time a public and a private nuisance. ${ }^{1 s}$ A private citizen is held entitled to sue to abate a nuisance, although the city charter authorized the common council to

16 City of Chicago v. Weber, 246 Ill. 304, 92 N. E. 859.

17 Kansas City v. Sihler Hog Cholera Serum Co., 87 Kas. 786, 125 Pac. 70. Petition for re- hearing overruled, 88 Kas. 164 , 127 Pac. 540.

18 Seigle v. Bromley, $22 \mathrm{Col}$. App. 189, 124 Pac. 191. 
declare and abate a nuisance, and the common council had not so declared the thing sought to be abated to be a nuisance. ${ }^{19}$ The question of nuisance is a fact to be proven.

21. Changes in Legal Nuisances. Changes in surroundings or in science may make that a nuisance which before was not so legally. A man may have been conducting a livery stable in a certain building withont creating a nuisance; but if an apartment building be erected on the adjoining lot, the odors and the noise arising from the stable may work such injury to the apartment owner that it will be considered a nuisance, and ordered abated by removing the horses. ${ }^{20}$

Formerly a manure pile was regarded as a nuisance when it was near and large enough so that its odor was offensive, or the sight was repugnant. Practically it might be said that under the old idea a manure pile was a nuisance in proportion to its size, and to the proximity; and if it chanced to be a hundred feet away it would hardly be deemed a nuisance. Modern scientific advances have changed this. The house fly is known to be a carrier of infectious diseases from one person to another. The fly is a nuisance per se. Flies breed in stable manure. So do rats, and rats are also nuisances per se. The manure pile is therefore regarded as a nuisance because flies and rats there breed. Now a fly, when he first emerges, may go in a straight flight five or six hundred feet, and rats easily travel as far. Though the pile may not be seen or its odor de-

19 Humphrey v. Dunnells, 21 Cal. App. 312, 131 Pac. 761.
20 Oehler v. Levy, 234 Ill. 595,85 N. E. 271. 
tected, under our present scientific information a manure pile may be considered as a nuisance if located within a radius of six hundred feet. Formerly it was only a private nuisance at best, but since flies are dangerous to the public health the pile now must be regarded as a public nuisance, and the owner may be subjected to a criminal prosecution even though there be no specific enactment so mentioning manure piles.

A manure pile which grows at the rate of a wagon load a week is not likely to produce many flies, unless the ground around it becomes saturated. The outside of the pile is too fresh for the maggots to have grown much, and the inside of the pile has generally developed so much heat as to kill those that have begun to grow. The little pile by the side of a blacksmith shop, which takes a month to produce a wheelbarrow load, is an ideal place for the breeding of flies. Therefore, whereas formerly it was only the large piles which were considered as dangerous, now the very small piles must be regarded as far more dangerous, and so greater nuisances.

It is such cases as the manure pile which show another very great difference in the law of nuisance. Formerly the scientific ideas were indefinite, and consequently health administration was largely left to individual communities, and was judged according to local needs and prejudices. Now, with the advancement of science it is quite possible to make certain general laws and applications. Health measures may therefore assume scientific exactness, and it is possible for any one to master the underlying principles, and 
know beforehand something of his personal rights and liabilities. Rats are nuisances because they destroy grain and other property worth millions of dollars each year in the United States. Scientific advances have shown that they are active in the spread of plague and very likely of other diseases. They are great travelers. An infected rat might easily find his way into a freight car in New Orleans, and land in St. Lonis or Chicago, and there infect other rats, that in turn miglit infect human beings. Though there are infected rats in New Orleans, it would hardly be suspected by the uninitiated that there was danger of contracting plague in Chicago, and a case might become well developed before the correct diagnosis would be made. So long as it was thought that the rat was only a danger to property the state officer's might very reasonably leave the protection of property from this danger to the individual owners; but now that the danger to the public is known, and it is a danger which lurks mnsuspected, the state not only would have a right, but it might be considered a duty, to enact laws which would restrict the breeding places of those pests, and also require the rat-proofing of buildings in cities of a given size.

22. Treatment of Nuisances. A nuisance may be prohibited, abated, or regulated. It may be prohibited, by a state statute, a city ordinance, or by an injunction issued by the court. Violation of the prohibition makes the violator subject to criminal prosecution. It may be regulated, as by ordinances which make the sale of liquor permissible only within certain hours. More frequently 
the business may be conducted only under certain conditions which preserve for the community such a supervision as to limit the chance of harm resulting, as in the dairy and meat producing industries.

A nuisance per se should be abated. This is frequently accomplished by the destruction of the thing itself; or it may be abated by so altering the conditions, as of manufacture, as to remore the possibility of danger. An unguarded excavation by the side of a public walk, into which passing individuals may fall, is a nuisance. ${ }^{21}$ It may be abated either by the erection of a guard, or by filling, but the guard must be a real protection, such as would prevent accident. Summary abatement, though often necessary, is not always either permissible or advisable. If the thing destroyed have real value, the officer or other person cansing its destruction may be held liable for damages. ${ }^{22}$ A stable is not a nuisance per se, and every property holder has the right to maintain one, even in a city, unless the condition of the particular stable arising through defendant's negligence is such as to render it a nuisance. ${ }^{23}$ The fact that the stable is a nuisance does not justify the destruction of the building. ${ }^{24}$

A person or an animal afflicted with a communicable disease is a nuisance in esse. The disease germ is a nuisance per se. Unfortunately this

21 Town of Newcastle v. Grubbs, 171 Ind. 482, 86 N. E. 757.

22 Miller v. Horton, 152 Mass. 540 ; Pearson v. Zehr, 138 IIl. 48 .
23 Porges v. Jacobs (Ore.), 147 Pac. 396.

24 Miller v. Burch, 32 Tex. 208. 
nuisance per se cannot be destroyed immediately without the destruction of the person or the animal. Ordinarily these cases are treated in some sort of quarantine. In the case of diseased animals public weal frequently calls for the destruction of the infected individuals, and sometimes this must also include all those that have been exposed to the infection. A tubercular cow is a nuisance, in that she is a danger to other animals, or to the users of her milk. However, she may have a special value for breeding purposes, and her milk may be pasteurized so as to reduce, or remore, danger from that source; and she may be kept so isolated as to not endanger other animals. While it is generally held that no compensation is due to the owner for the destruction of a muisance under police power, in such cases as this the difficulty in destroying the nuisance without also destroying valuable property has caused the establishment of a practice, as a matter of public policy, of rendering some compensation to the owner. Apparently this is more a matter of policy than of right. This will be more fully considered in a later section. ( $\$ 113$.)

One of the powerful weapons for the restraint and prevention of nuisances is found in eivil suit. This may be maintained either by the public, or by private indiriduals. If it be a private nuisance it must be by the parties injured, and a private party may only sue for recovery of damages from the maintenance of a public nuisance when his own property, or person, shall have been especially injured. ${ }^{25}$ Since it is not to be presumed that a nui-

25 Hoyt v. MeLoughlin, 250

III. 442,95 N. E. 464 . 
sance will be permitted to continue if it be possible to abate it by expenditure of labor and money, the measure of damages will be such damages as have already occurred. ${ }^{26}$ In a suit for damages resulting from the nuisance from maintenance of a stable, the court held that the measure of damages is the reduction in the value of the plaintiff's property, plus compensation for the plaintiff's discomfort, and not the depreciation in the value of the plaintiff's property. ${ }^{27}$

23. City Must Not Commit Nuisance. A city has no right to commit a nuisance, such as the pollution of a stream to such a degree that it injures the lower riparian owners. This offense is most often committed by the discharge of crude sewage into natural waters. "A municipal corporation has no more right to injure the waters of a stream or the premises of an individual by the discharge of sewage into the stream than a natural person, and incurs the same liability by so doing. ${ }^{28}$ This does not mean that the city lias no right to empty serrage into a stream, but that it must not commit nuisance by so doing. The sewage may be so treated that in the place of making a nuisance it will tend to remove the nuisance already existing in the stream. ${ }^{29}$ The fact that a city has been discharging its sewers into a stream does not give it a right so to do. The eity may have grown from a little village, and while the water of the

26 Southern Ry. Co. v. Poetker, 46 Ind. App. 295, 91 N. E. 610.

27 Porges v. Jacols (Ore.), 147 Pac. 396.

28 Little v. Town of Lenoir,
151 N. C. 415,66 S. E. 337 ; State Bd. of Health v. Greenville, 98 N. E. 1019,86 Ohio 1.

29 Atty. Gen'l v. Birmingham, Tame and Rea Dr. Dis. L. R. C. D. (1910), 1 Ch. 48. 
stream might not be perceptibly injured by the sewage of the village, that of the city might be dangerous. This matter is more fully discussed in my work on The Legal Privciples of Public Health Administration, $\S \$ 440$ and following, to which reader is referred.

The particular point interesting to stock handlers in this regard is the danger to a stream running through a pasture. The chemicals used in a factory may render the stream useless for the watering of the stock, or even dangerous. This is a special damage to the owner of the pasture land, and he has a right of individual action, independent of any criminal prosecution, or other steps taken by the governmental authorities. What the property owner desires is the abatement of the nuisance. A suit for damages might very likely not accomplish the abatement, and repeated suits would thus be brought, for the limit of damages is that which can be shown to have occurred. The proper action here is an application for an injunction, after which an action in damages may or may not be advisable. ${ }^{30}$ (See also $\S 106$. .)

\section{Authority for Abatement, Not for Construc-} tion. Unless the power be distinctly given, the authority conferred upon an officer or department to abate a nuisance does not carry with it the authority to direct any special style of construction. Thus, authority to abate a nuisance at the expense of the owner does not empower the board of health to require a new building, more in accord

30 Bernard 5 . Willamette Box \& Lumber Co., 64 Ore. 223, 129 Pac. 1039; Lavner v. Inde- pendent Light \& Water Co., 74 Wash. 373, 133 Pac. 592. 
with the adranced ideas in sanitary construction. ${ }^{31}$ Neither does it empower the board to direct changes of such a scale as to bring it within the definition of public works, and assess it upon the property. $^{32}$ The object sought is the abatement, and the property owner is obliged to abate, but he is not obliged to abate in the specific manner directed by the exccutive, muless that specific authority was given. ${ }^{33}$

Even where the authority to direct construction may have been given and exercised, where plans have been approved by the departmental engineer, this does not justify the continnance of a muisance. The engineer may have made an el'ror in his computation; or he may have gone at his work blindly, and without sufficient knowledge of the subject; or he may have been influenced in his judgment. After approval of the plans by the state board of health it was found that when the Collingsworth Serverage Works were put in operation, as an actual fact, a nuisance was committed. The court said that no matter how expensive the works may have been, or how umprofitable the enterprise might be, neither elerient was sufficient to absolve the company from maintaining a nuisance, due to faulty construction of the plant, or to negligence in its operation. ${ }^{34}$

31 Eckhardt v. Buffalo, 156 N. Y. 658.

32 Haag v. City of Mit. Vernon, 58 N. Y. S. $585,41 \Lambda_{\text {Pp. }}$. Div. 366.
33 Durgin v. Minot, 203 Mass. 26, 89 N. E. 14 .

s4 State v. Collingsworth Sewerage Co., S5 N. J. L. 567, $89 \mathrm{Atl} .525$. 


\section{PART II \\ PERTAINING TO VETERINARY \\ PRACTICE}





\section{CHAPTER III.}

REGULATION OF THE PRACTICE OF VETERINARY SURGERY.

§30. Authority of the State.

\$31. License to Practice.

\$ 32. Standards for License.

\$33. Appointment of Examiners.

$\S 34$. Exceptions.

$\$ 35$. Certificate in the Place of License.

§36. License by Reciprocity.
$\S 37$. The License Itself.

$\S 38$. Revocation of License.

$\S 39$. Attorney for Board of Examiners.

$\S 40$. What Constitutes Practice of Veterinary Medicine or Surgery?

$\S 41$. Practice as a Company. $\S 42$. Prosecutions, by Whom?

30. Authority of the State. According to the American legal system, each state has the guardianship of the welfare of people and property within its own boundaries. Under police power it has not only the right, but also the duty, to enact such laws, and enforce such regulations as seem to be necessary to insure the good of its citizens. Veterinary medicine and surgery is a branch of the general practice of medicine and surgery, and in point of legal principles involved it in no wise differs from those pertaining to the practice of those arts among human beings. Both involve the same general lines of study. While the diseases of human beings differ in many instances from those afflicting animals, and while the appropriate treatment may vary, essentially the two sciences are the same. In the past the treatment of human beings has attracted rery much more attention, and has therefore adranced more both 
as a seience and as an art. Is a natural consequence its regulation by law became apparent long' before a similar restriction was required in the practice of the arts upon these lower animals.

If in the past these veterinarians were looked upon as a lower rank of men, it was because there was generally little attempt at making their practice really scientific. The blacksmith who became "knowing with horses," and the dairy man who had considerable experience, were therefore consulted by their neighbor's in time of need. As a rule they were men of very limited education, and so soon as they really attempted to make a special study of the subject they abandoned the treatment of animals for the treatment of men. Some of them, during their transition period, maintained two offices. In one locality they were known as "lioss doctor's," while in the other they attempted to be known as "doctor's of medicine," but as soon as possible the first practice was dropped for the "more respectable" one. The result was that when the medical profession was already filled with members striving for a living, that of the veterinarian lacked competent practitioners. In the medical ranks it became apparent that the good of all concerned demanded that the practice be so restricted as to exclude the most incompetent pretenders, and laws were accordingly passed, and disappointed practitioners thus excluded tested the provisions in the courts. It is only recently that it has been possible to draw the lines between the self-made pretenders in veterinary practice and the conscientious students of the science. While most of the points have been deeided with 
regard to human treatment, the legal right of the state is the same in veterinary regulation. ${ }^{1}$

The first ease which I have found in which the right to regulate the practice of medicine was made distinct from the holding of a medical degree was the famous Bonham case during the reign of James I of England. Bonham had been graduated in medicine from the University of Cambridge in 1595. Under that diploma he undertook to practice medicine in London. Henry VIII had granted to the College of Physicians of London (which is not a teaching college as we know them), the supervision of the practice of medicine within the city of London, or within seren miles of the city, and no person was to be permitted to so practice unless he be a member of the said College of Physicians. King Henry said that he "held it necessary to restrain the boldness of micked men who professed physic more for avarice than ont of confidence of a good conscience." The statute of Henry permitted the imposition of a fine upon violators, and by a later amendment violators might be imprisoned. Bonham appeared before the board of censors of the College of Physicians several times, but failed to pass the required examination, and he was forbidden to practice. He persisted, and in 1606 he was arrested by the censors, and was tried by them, fined and imprisoned. He brought action against the censors for false imprisonment, and the case was heard before Lord Coke. ${ }^{2}$ Lord Coke held that under the terms of the statutes no man could be impris-

1 Public Health, 425.

28 Coke, 107a. 
oned unless he were guilty of malpractice, but that the law clearly provided for a fine. However, he further held that "the censors cannot be judges, ministers, and parties; *** and it appears in our books, that in many cases the common law will control acts of parliament, and sometimes adjudge them to be utterly void; for when the act of parliament is against common right and reason; or repugnant and impossible to be performed, the common law will control it, and adjudge such act to be void." So much, therefore, of the statute as contemplated that the censors be at the same time complainants, executives and judges in regulating the practice of medicine, he held void. He also held that the trial must be substantiated by a legal record of the proceedings, in order to justify either fine or imprisomment. With slight changes in the wording the decision of Lord Coke is good law today in the United States. It gives the gist of the whole matter. The state has the right to control the practice, though the person may hold a diploma. He may be forced to take an examination to demonstrate his fitness. He may be punished for violating the provisions of the statute enacted.

It has been repeatedly lield that the states have authority thus to regulate the practice, and that this power is reserved to the individual states. ${ }^{3}$ The law as to veterinary practice was tested in

3 Dent v. West Virginia, 129 U. S. 114; Hawker v. New York, 170 U. S. 189; Jacobson v. Massachusetts, 197 U. S. 11 ; State v. Hathaway, 115 Mo. 36 ;
Reetz v. Michigan, 188 U. S. 505; Watson v. Maryland, 105 Md. 650, 66 Atl. 635; Ex parte Spinney, $10 \mathrm{Nev} 323$. 
Nebraska, and the court held that "Laws providing for the examination and licensing of persons practicing veterinary medicine, and forbidding. persons not licensed from assuming the title of Veterinary Surgeon, is constitutional" and hence valid. ${ }^{*}$ See $\S \S 171,172$.

31. License to Practice. The license is used for two purposes in governmental operations. It may be for taxing purposes, either directly or indirectly; or as a means of registration and regulation of things or acts possibly dangerous to the community, or capable of being misused to the detriment of the citizens. The direct use for purposes of taxation refers to such cases as those in which the state or city may require the issuance before permitting the business or possession. In these cases the license fee, or tax, is relatively high, though there may be very great differences in the amount. An indirect use of the license is shown in the operations of the Harrison antinarcotic law. This has been attacked as an attempt of the nation to use police power within the states, but the court has denied this intent. The fee charged is insignificant, and probably does not pay for the enforcement of the regulation. However, opium is not produced commercially in the United States. There has been reason for believing that much of the drug has been smuggled into the country, and the country has thus been defrauded ont of import duties in large amounts. By the provisions of the Harrison law all lawful holders of opium and its

4 Ex parte Barnes, and, Barnes v. State, 83 Neb. 433 , 119 N. W. 662 . 
derivatives are registered, and all of the drug is also registered and so easily traced from importation to consumption. Where registration is the chief object, the fee must be small, or it will defeat itself. Where income is the object the fee may be ample, but not so excessive as to be prohibitive. Under police power, the fee may be small for registration purposes, large for regulative reasons (such as high license in the liquor business), or moderate, and practically supplying the funds for enforcing the special regulative law. This last is the case with regard to the license fees charged in the regulation of the practice of medicine in any of its branches.

32. Standards for License. The object of laws regulating the practice of medicine is to insure the reasonable competence of those attempting to practice. It rests with the judgment of the legislature as to what kind of a standard shall be established, and the tendency must be for the gradual elevation of the standard with the advance of scientific knowledge, and of the number of practitioners. When practitioners are few, the standard must be relatively low, or those in need of such service may be deprived of help. The first requirement has generally been the possession of a diploma from a legally incorporated medical college, or an examination before a board of examiners composed of experts. The next step has been to specify certain standards for the schools whose diplomas will be accepted, and then to require both diploma and examination. In addition it is customary to require evidence of good moral character, for the intimate relationships which the 
practice involves, and the opportunities for undetected fraud, demand this additional protection. What shall be the moral standard, so long as it is reasonable, is a matter for the legislature to decicle. $^{5}$

Under the public act of 1899 in Michigan, establishing the State Veterinary Board it was held that the board had no discretionary anthority to determine whether a college of "Veterinary Medicine and Surgery" existing under the Compiled Laws of 1897 is a regular school or college; or to refuse to give a certificate to practice to a person holding a diploma from such college. ${ }^{10}$ A later statute of the same state provided that no person shall be registered as a veterinarian, or veterinary surgeon, without proof that he is the lawful possessor of a diploma from a regular veterinary college, or the veterinary department of a state institution of learning, or college of medicine, having at least three sessions of six months each. A veterinarian who had graduated from such an institution made application for registration and was refused by the board. He appealed to the courts, and the decision was that an applicant must have actually attended three courses of six months each; and the fact that at the time he received his diploma from a veterinary college it had adopted the three years course would not

5 Dent v. West Virginia, 129 U. S. 114; Hawker v. New York, 170 U. S. 189; State v. State Medical Examining Board, 32 Miun. 324; Thompson v. Hazen, $25 \mathrm{Me}$ 104; State v. Hathaway, 115 Мo. 36 ; East- man v. State, 109 Ind. 278; State v. Call (N. C.), 28 S. E. 517; Collins v. State, 32 S. C. R. (U. S.) 286.

10 Wise $v$. State Veterinary Board, 138 Mich. 428, $101 \mathrm{~N}$. IV. 562 . 
serve to qualify lim, if in fact he had taken only the two years course formerly required. ${ }^{11}$ Where the law provided that one who had practiced veterinary medicine or veterinary surgery, "in their various branches," for five years before the passage of the act could be registered before January 1, 1908, on filing a proper affidavit and letters, the court held that the requirement that the registration must be made before the said first day of January, 1908, was mandatory; and that the applicant, having failed to register before that date, was not entitled to register under that provision. ${ }^{12}$ But where the application was properly made, but it was later found that the letters failed to show that the signers were stock raisers, or that the applicant had practiced five years, upon a notification by the board it was held that the record might be corrected, and the proof be made complete in January, 1909, although after the said first day of January, 1908. ${ }^{13}$ Where the application failed to include proof of practice "in their various branches," and the letters of recommendation did not cover the entire period of five years, nor indicate the kind of service rendered, the court held that the veterinary board had properly denied the application. ${ }^{14}$

It will be noticed that in the Jennings case above

11 Folsom $\nabla$. State Veterinary Board, 158 Mich. 277, $122 \mathrm{~N}$. W. 529 .

12 Kerbs v. State Veterinary Board, 154 Mich. 500, 118 N. W. 4 .
13 Jennings $\nabla$. State Veterinary Board, 156 Mich. 417, 120 N. W. 785 .

14 Dusaw v. State Veterinary Board, 157 Mich. 246, $121 \mathrm{~N}$. W. 759 . 
mentioned, the essential proof had been recorded, but that there appeared certain defects in which the evidence was not sufficiently clear upon the face of the documents. In the Dusaw case there were vital defects in many particulars.

Records must not be falsified. A county court in New York has no jurisdiction and no authority to make an order directing the county clerk to enter the name of a physician in the "Register of Physicians and Surgeons," say on July 24, 1908, as of Dec. 1, 1899, after he had, on the latter date, omitted to register his diploma in the office of such clerk, as the law required. Any such registration is a nullity, and on proper application it will be racated and cancelled. ${ }^{1 \overline{5}}$ The fact that one practiced medicine for more than ten years without authority required by statutes, gives no right to practice. ${ }^{16}$

In the absence of special enactments, it is presumed that any person holding himself out as a practitioner of veterinary medicine and surgery is legally qualified. When there is a statute, the terms of the statute must be met, unless the legislature shall have exceeded its authority. Generally the matter of applying the law and issuing the license is left to a board. In its rules governing the issuance of the license the board must not go beyond the terms of the statute. ( $\$ 5$.) Where a medical board attempted to add requirements beyond those in the statute, it was held that they

15 In re, Somme, 136 N. Y. Commonwealth r. Rice id.; HarSup. 57.

16 Driscoll v. Commonwealth, gan v. Purdy, $93 \mathrm{Ky} .424,20 \mathrm{~S}$. IV. 432 .

93 Ky. 393, 20 S. W. 431; 
exceeded their authority, and the issuance of the license was secured by mandamus. ${ }^{17}$

The issuance of the license is a purely executive duty, even when the officer issuing it is vested with discretion. ${ }^{18}$ If the statute merely requires presentation of a diploma from a legally organized college, the officer must be satisfied that the diploma is genuine, that it was issued from a college which was legally organized, and that the holder is lawfully entitled to the same. Frauds have been attempted in each of these points. If in addition, the statute adds the requirement that the college shall be of good standing, without making it clear what the basis of judgment must be, it is left to the board to determine this point, and it is presumed that the board shall act with discretion, and not arbitrarily. All tests must be reasonable and impartial; they must not violate the principle of equal protection, nor create any special privilege. The qualification required must be obtainable by reasonable effort. ${ }^{19}$ There is no "school" in science, and the idea of a "school" of medical practice is essentially commercial. The law should be based upon scientific knowledge and training, and as such no special method of treatment should be favored or discriminated against. ${ }^{20}$

Owing to the very great differences which were found in the teaching of different schools, and as

17 State v. Lutz, 136 No. 633.

18 People v. Apfelbaum, 251 IIl. 18.

10 Dent $\mathrm{v}$. West Virginia, 129 U. S. 114.

20 Nelson v. State Bd. of
Health, $22 \mathrm{Ky}$. L. 438, 50 L. R. A. 386 ; State v. Gregory, 83 Mo. 123; White v. Carroll, 42 N. Y. 161; Allopathic St. Bd. of Medical Examiners v. Fowler, 50 La. Ann. 1358, 24 S. 809. 
to the strictness with which candidates for degrees were tested, it has been found advisable to require, either with or without a diploma, that all candidates for medical license shall be examined by officers of the state issuing the license. The statute should be definite as to the amount of education which the candidate should have had aside from his professional course, should specify whether or not a candidate not possessing a diploma shall be admitted to license examination, and it should further state in what branches he should be examined. Though the work of the examining board is a quasi-judicial act, it is executive in nature. It is presumed that the examination will be conducted in an impartial manner. If it is not so conducted, it is arbitrary, and therefore illegal. ${ }^{21}$

33. Appointment of Examiners. It is one of the principles of the American governmental system that appointment to office must be made by the same branch of service. That is, since the work of issuing a practice license is executive in nature, the appointment of the examiners must be made by executive officers, and not by the legislative or judicial officers. ${ }^{22}$ The California medical practice act grants the appointment of examiners to the medical societies. So far as we are aware this particular act has not been tested judicially as to this point. In a somewhat similar case in Illinois it was held that the statute was unconstitutional as a delegation of authority, and as granting a special franchise. "Such rights as inhere in the

21 Public Health, 273.

22 Public Health, 283. 
sovereign power can only be exercised by the indiridual or corporation by virtue of a grant from such sovereign power, and when the state grants such a right it is a franchise." ${ }^{23}$ Power to appoint to office is an attribute of sovereignty. ${ }^{24}$ The legislature has no power to appoint to office. Not having the power in its possession it could not give it to a non-gorernmental organization. ( $§ 171-172$.

34. Exceptions. Statutes relative to the license of practitioners frequently make certain exceptions in their operation. If these exceptions are based npon reason, being neither arbitrary nor a mark of favoritism, they will not be held illegal in themselves, nor will they vitiate the legality of the rest of the statute. So, where an exception is made in the application, of those who have been practicing for a given number of years within the state before the passage of the statute, the law has been upheld. ${ }^{25}$ Also, an exception made with reference to physicians practicing in another state, in which they reside, but called within the state enacting the statute for purposes of consultation, or for the treatment of special cases, is upheld as legal." ${ }^{26}$ Such an exception might very reasonably exclucle from its operation practitioners residing in counties contiguous to the state making the provision. This would seem especially advis-

23 Lasher $\vee$. People, 183 Ill. 226, 233, eiting, Bd. of Trade v. People, 91 Ill. 88; People v. Holtz, 92 Ill. 426.

2*1 Blackstone Com. 272.

25 Williams v. People, 121
Ill. 84 ; State v. Vandersluis, 42 Miun. 129.

26 State v. Van Doran, $109 \mathrm{~N}$.

C. 864; Parks r. State, 159 Ind. 211,64 N. E. 862 . 
able where the adjoining state either has no law regulating practice, or where its regulation is inefficient. Otherwise, those unable to get a license, but desiring to practice within the state would simply take up their residence in the adjoining territory, and practice from that point of vantage.

35. Certificate in the Place of License. In Germany any one may practice medicine, without a license, but he is forbidden to assume the title of "doctor" or of "physician," unless he shall have passed an examination and received a certificate. ${ }^{27}$ A somewhat similar suggestion has been made in this country by the attorney of the state board in Wisconsin relative to the practice of medicine among human beings, because of the complications caused by the drugless methods of treatment. His suggestion was that practice be free, but that the board issue certificates to the effect that the holders show a certain degree of proficiency in the science. Fortunately, the character of veterinary medicine is such as to exchude from consideration the need for such a distinction. Animals are not likely to be subjected to mental healing.

36. License by Reciprocity. Although variously worded, many of the statutes regulating the practice of medicine require that the candidates shall be personally examined by the members of the examining board. This imposes upon them a service to be exercised with discretion. It is presumed that the members of the board have been selected with regard to their fitness to pass judg79.

27 Meyer Verwaltungsrecht, 
ment upon the candidates' qualifications. A duty with discretion cannot be delegated. ${ }^{28}$ This would seem to prolibit the employment of readers to mark the examination papers, for such reading makes the employed readers the real judges. Few states have provisions in their statutes for license by reciprocal agreements with other boards. In the absence of distinct provisions, the legality of reciprocal licenses is open to very grave question. Some of the statutes provide for examinations in writing, and that the examination papers shall be preserved in the office of the board. It is difficult to see how such a provision can be observed in the case where a license is issued solely upon the basis of one previously issued in another state. Where the duties of an officer are partially ministerial (such as the writing of a license), they may be delegated; but where they are judicial, or quasi-judicial in nature (as in the holding of an examination for license), they cannot be so delegated. ${ }^{29} \mathrm{~A}$ board of examiners in one state cannot, therefore, lawfully appoint the board in another state as its deputy to make examinations, nor accept the finding of the foreign board as its own decision in the case. (See § 9.)

There is another objection to such license by reciprocity. A foreign board is not under the jurisdiction of the state, and in case of malfeasance it could not be punished. Citizenship is one of the prerequisites for the holding of an office, and the foreign board may not therefore assume this relationship.

28 Public Health, 272, 426. 570; Mechem, Public Officers, 20 Throop, Public Officers, 567, 568. 
It may seem advisable that a provision for license by reciprocity should be made, but if desired it should be made in the statute. Some time ago a graduate of an Italian university settled in Buffalo to practice medicine. He was informed that he must be examined in English. He then went to Michigan and there secured a license, which he presented in New York with a demand for a license by reciprocity. This was refused, and he then sought by mandamus to compel the issuance of the license. The court refused to interfere, and held that his efforts to avoid the New York examination, and obtain license through subterfuge, justified the refusal of the board. ${ }^{30}$ The West Virginia Board has a rule relative to reciprocity licenses that the applicant must have been practicing in the primary state for at least one year. One Thomas, holding a Maryland license, sought by mandamus to compel the issuance of a reciprocal license in West Virginia. The court upheld the refusal of the board. ${ }^{31}$ It will be presumed that a man is not a legal practitioner until he proves to the contrary. ${ }^{32}$ The Minnesota statute providing for license by reciprocity contains no provision for an appeal. The right to appeal is purely statutory. There is therefore no appeal from the decision of the board refusing to issue a license by reciprocity. ${ }^{33}$

37. The License Itself. A license gives only

30 People ex rel. Pisani v. McKelway, 148 N. Y. Sup. 818.

91 Thomas v. State Board of Health, 72 W. Va. 776,79 S. E. 725.
32 Miller v. State, 105 Miss. 777, 63 So. 269.

83 Williams v. State Bd. of Med. Exrs., 120 Minn. 313, 139 N. W. 500 . 
such rights and privileges as its wording shows. A license to practice veterinary medicine would give no right to prescribe for a human being. Whenever the existence of a license is lawfully questioned, it is not sufficient to prove its possession by parol evidence, nor is it sufficient to produce a certificate that one is licensed. ${ }^{34}$ The license may be a forgery, or it may have been canceled, or the certificate may be wholly false. By the general rules of evidence, when the existence of a document is asserted, the document itself should be produced. ${ }^{35} \quad$ The same statements are true as to the possession of a diploma. The diploma itself should be produced. It may be possible that the lawfully issued diploma might have been destroyed, and that a duplicate diploma could not possibly be procured. It would, under such conditions, be an injustice to the victim of misfortune to enforce this rule; but the greatest caution is needed in accepting proofs in such a case. This was illustrated in a case which came under the writer's personal observation. A physician claimed to have been graduated from an institution which ceased to exist during the Civil War. He claimed that many years afterward his office was burned and that his diploma was destroyed. He made affidavit of these facts, or asserted facts. Owing to the writer's official relation with a medical society the applicant was referred to him for recognition. In spite of recommendations from physicians and clergymen, a cross examination,

34 Commonwealth v. Spring, 19 Pick. 396.
35 Greenleaf, Evidence, 79 ; Wharton, Criminal Lar, 2434. 
with careful scrutiny of the evidence submitted, failed to substantiate the claims. Though he had been definite as to dates and names, known facts contradicted his statement. Shortly after that the applicant removed to another section, and there was convicted of serious crimes, and presumably died before the expiration of his term in prison.

38. Revocation of License. The courts recognize the fact that the right to practice medicine is a valuable property right. ${ }^{36}$ However, the granting of a license does not operate as a surrender of police power on the part of the state. $(\S \S 14,20$.) Therefore, a license once granted may be canceled. ${ }^{37}$ Because the license, and the right to practice dependent thereon, become a property right, and the license is in effect a contract with the holder, the terms under which it may be revoked should be clearly defined in the statutes. Professor Freund doubts the justice of such revocations; ${ }^{38}$ but experience has shown that such a course may be necessary, and this power of the state has been repeatedly upheld. The Minnesota court held that under the laws of 1883 providing that refusal of certificates to practice medicine might be made by the board "to individuals guilty of unprofessional or dishonorable conduct, and it may revoke certificates for like cause," the power to revoke certificates is not a judicial power which cannot under the constitution be vested in

36 Hewitt v. Board of Medical Examiners, 148 Cal. 590, 84 Pac. 39.
37 Public Healtir, 428, 212. 38 Police Power, 546. 
the board of examiners. ${ }^{39}$ Publishing an advertisement of ability to cure is such "unprofessional and dishonorable conduct" as to justify a revocation. ${ }^{40}$ The power to revoke a license for objectionable advertising was upheld by the Arkansas court, which held that the right to practice was not a property right, and that the revocation of the license was not a judicial power. ${ }^{41}$ In Missouri, in a somewhat similar case, the revocation was not sustained, the court holding that the statute provided for the revocation for dishonorable acts, not for evil thoughts, or an alleged willingness to commit abortion; and there was nothing essentially wrong in the advertisement itself. ${ }^{42}$ It seems better to acknowledge that the right to practice is a property right, but it is a right which is held subject to the doctrine Alienum tuum non laedat. (\$13.) In Arizona a license was revoked for the publication of misleading advertisements, and the court held that such advertisement must be generally considered as dishonorable conduct, and the revocation was sustained. ${ }^{43}$ One Berry advertised that he could cure cancers and gall stones. This advertisement was considered false and misleading, and therefore unprofessional. For gall stones he gave large doses of olive oil, and

39 State v. State Board of Med. Examiners, 34 Minn. 387, 26 N. W. 123.

40 State v. State Board of Med. Exmrs., 34 Minu. 391, 26 N. W. 125.

41 State Med. Board v. MeCrary, 95 Ark. 511, 130 S. W. 544.
42 State ex rel. Spriggs $\nabla$. Robinson, 253 Mo. 271, 161 S. IV. 1169.

43 Aiton v. Board of Medical Exrs., 13 Ariz. 354, 114 Pac. 962. 
the resulting lumps of soap which the patient passed he pronounced to be gall stones. The revocation of his license was sustained. ${ }^{44}$ An act forbidding physicians to solicit patients by paid agents was upheld as a valid use of police power in Arkansas. ${ }^{45}$ While the Kentucky statute provides for the revocation of a physician's license for unprofessional conduct, the context shows that there must be moral turpitude, and an advertisement is not sufficient ground for revocation of license unless it involves moral turpitude and fraud. ${ }^{46}$ The New York statute provides for the revocation of the license of a physician who had been convicted of crime, and the Supreme Court of the United States upheld the revocation of one Hawker, who had been convicted nine years before. ${ }^{47}$ Since this revocation is essentially in the nature of criminal punishment, it is not sufficient that the board believe that the man is guilty, but the evidence must show that he is in fact guilty. ${ }^{48}$

The statute, in providing for the rerocation of license to practice, should prescribe, not only for what cause this penalty should be inflicted, but also, how the revocation should be made. It would seem, in order to comply with the provision relative to "due process of law," that formal notice of the charges made should be given to the holder of the license, either by mail or by personal

44 Berry v. State (Tex.), 135

S. W. 631.

45 Thompson v. Von Lear, 77 Ark. 506.

40 Foreman $\nabla$. State Bd. of Health (Ky.), 162 S. TV. 796;
Chenowith v. State Bd. of Med. Exrs., 57 Col. 74, 141 Pac. 132. 47 Hawker v. New York, 170 U. S. 189.

48 Board of Med. Exrs. v. Eisen, 123 Pac. 52, 61 Ore. 492. 
service, and that a day be fixed for a hearing. The record of that hearing should show the transactions with sufficient clearness so that in the event of a judicial investigation it would be evident to the court exactly what had transpired. The board, or officer having the power to revoke the license, should also have the power to compel the attendance of such witnesses as might be deemed necessary, with the power to administer the oath; and the defendant should have the privilege of cross examination. Under such conditions, unless otherwise provided by statute, the executive determination would be deemed final as to questions of fact, though the courts would still have jurisdiction as to questions of law. ${ }^{49}$

Where the revocation depends upon a former conviction in a court, the notice to the defendant may only state that he is summonsed to appear before the board, or officer, and show cause why his license should not be revoked. If then he fails to appear the license may be at once revoked, the record showing the notice given, the fact of his non-appearance, and the fact of revocation. A physician thus summonsed to appear before a board for a hearing preparatory to the revocation of his license is not entitled to an injunction to prevent such hearing. ${ }^{50}$ The Arkansas statute provid ed for the revocation of the license of a physician by a mayor upon conviction of any crime involving moral turpitude. Though the sale of liquor is a statutory crime, it does not, according to the court,

49 Nishimura Ekiu v. U. S., 142 U. S. 651.

50 Wolf v. Board of Med.
Exrs., 109 Minn. 360, $123 \mathrm{~N}$. W. 1074 . 
involve moral turpitude. The term "moral turpitude" refers to something immoral in itself, regardless of the fact that the act may be punishable by the terms of the statute. The revocation was not sustained. ${ }^{\text {s1 }}$

39. Attorney for Board of Examiners. In prosecutions for violation of the medical practice acts it is frequently necessary to have the services of an attorney, as well as for legal advice which the board may from time to time desire. Medical license boards are state officers, and it is the duty of the Attorney General of the state to render this service, either by his own service, or that of his office assistants detailed for such special work, or through the ordinary prosecuting attorneys of the various counties, by whatever name they may be called. Unless the law specifically provides for the employment of an attorney for the consultation of a board, or for the prosecution of violators of acts requiring licenses, the board has no authority for such employment; neither is there authority for the payment for such service. By general statutes these duties derolve upon the office of the Attorney General and the ordinary state's attorneys, or prosecuting authorities. ${ }^{52}$ By the constitutions of many states it is provided that there shall be no subject treated in an act which is not indicated in the title; and it is also provided that appropriation acts shall contain no other legislation. Under such conditions, even where the

51 Fort v. City of Brinkley, 87 Ark. 400, 112 S. W. 1084.

52 State ex rel. Board of Med. Exrs. v. Clausen (Wash.), 146
Pac. 630; Reports, Attorney General, Illinois (1902), 391; (1910), 305. 
appropriation act makes provision for the pay of such a special attorney, it would seem that such employment would be unconstitutional in the absence of special legislation in addition to the appropriation. Moreover, such special employment seems unadvisable, because it tends to conflict with the regular authority of the office of the Attorney General.

\section{What Constitutes Practice of Veterinary} Medicine or Surgery? The act regulating the practice of the veterinary profession should define, with considerable preciseness, what shall be deemed practicing that profession. First it should make the use of the designation "Veterinarian," or "Veterinary Surgeon," or "Doctor of Veterinary Medicine," or "Doctor of Veterinary Surgery," or of such initial letters as "V. S." or "D. V. M." or "D. V. S." on signs, door plates, or in advertisements, as presumptive evidence of such practice. The actual treatment of injuries or diseases in animals not belonging to the human family, whether by drugs, manipulations, applications, or by the use of surgical instruments should be deemed practice of veterinary medicine or surgery, whenever done for pay, or upon the animals belonging to another, unless in an emergency and gratuitously. Holding one's self out to practice, either by advertisements, signs, cards, by personal solicitation, or otherwise, should be sufficient eridence to convict of violation of the statute; but in every case the terms of the statute must govern its application.

The responsibilities of the practice are very great. A single incompetent, or careless, or un- 
principled practitioner may easily do the entire nation millions of dollars worth of injury. A veterinarian, buying cheap serum for the treatment of hog cholera, may spread the foot-andmouth disease, with its resulting paralyzing influence even upon the dairy interests. It is the incompetent man who least realizes the dangers, and he fails also to realize that cheap products generally indicate inefficient care in production. It is the incompetent man who is not prepared to recognize a dangerous disease which may be new in the district. It is therefore a prime necessity, under the present state of advancement in scientific knowledge of animal diseases, for the safeguarding of the great animal industry of the United States that strict laws be enacted, and enforced, regulating the practice of the veterinary profession.

Such serious results of incompetence of practitioners of veterinary medicine as the death of a number of mules from tetanus received when they were inoculated with anti-anthrax serum, or outbreaks of foot-and-mouth disease in hogs received in anti-hog-cholera serum, tend to prevent the use of these great aids in the restriction of disease. They also cast a reflection upon the character of the profession. On the other hand, a stringent law regulating the practice tends to elevate the standard of the profession, and to attract men of the highest scientific attainments. Such men are needed in the profession by the animal industries, but they are loath to enter competition, and be classed generally on the same level, with men who are deficient in ordinary education, and whose 
general scientific knowledge is practically nothing.

Essentially the practice of the veterinarian is in no wise inferior to that of the practitioner among human beings. It requires even a wider scientific knowledge, for it deals with many kinds of animals, each differing from the others far more than the difference between human beings. The veterinarian also deals with them in a greater variety of ways, for he must keep constantly in mind the many possible uses of the animals with which he deals. His problems of disease restriction are greater. Today the body of competent veterinarians is small in the United States. Paradoxical as it may seem, restrictions upon the practice will tend to increase this small nucleus, by eliminating the degrading elements.

While the question as to what shall be considered illegal practice of veterinary medicine and surgery will depend upon the wording of the special statutes of the individual states, and in this country there may have been no judicial determination of that point, there have been some decisions in England which will serve as precedents for American cases. A farrier who is not registered as a veterinary surgeon, nor certified by the Highland and Agricultural Society of Scotland, violates the law by using the sigm "Veterinary Forge" on his premises, or on his billheads. ${ }^{53}$ Also one who was not on the register of Veterinary Surgeons, nor a holder of the certificate of the H. and A. S. of Scotland, put out a sign "Canine Specialist. Dogs and Cats treated for"

53 Royal College of Veterinary Surgeons v. Robinson, 61
L. J. C. 146 (1892), 1 Q. B. 557. 
all diseases." The court held that by so doing he claimed that he was "specially qualified to practice veterinary surgery within the meaning of the law." 54 A chemist published a book upon animal diseases, and advised under certain conditions the calling of a veterinary surgeon. In this book he spoke of himself as a "pharmaceutical and veterinary chemist." It was held that in so doing he was leading people to suppose that he was legally qualified to practice veterinary medicine within the meaning of the law. ${ }^{55}$

41. Practice as a Company. A sign was placed upon a building, and advertisements were published, bearing the words "Churchill's Veterinary Sanatorium (Ltd.), Dogs and Cats boarded. James Churchill, M. D. (U. S. A.) Specialist, Managing Director." Churchill was not registered as a veterinary surgeon, nor certified by the $H$. and A. S. of Scotland. Under the criminal code there was no provision for the punishment of an incorporated limited company. Therefore, the court issued an injunction against the company, and against Churchill personally, to restrain the continuing to make this false representation. ${ }^{56}$ In a somewhat similar case in New York, a licensed physician was employed by a drug company which advertised free examination and free treatment by competent physicians for those using its medicines. It was shown that he did make certain

54 Royal Col. of Vet. Surg. v. Collinson, 77 L. J. K. B. 689 (1908), 2 K. B. 248.

55 Royal Col. of V. S. v. Groves, 57 J. P. 505.
56 Atty. General v. Churehill's Veterinary Sanatorium, Ltd., 79 L. J., Ch. 741, (1910) 2 Ch. 401 ; Atty. Gen. v. Myddletons, Ltd. (1907), 1 J. R. 471. 
examinations for one holding the card of the company, and that he refused to accept payment therefor. The court sustained his conviction of illegally practicing medicine, in that he was practicing under the trade name of The Standard Pharmacy Co. ${ }^{57}$

42. Prosecutions, by Whom? In this country, as in England, it is customary that prosecutions for violation of practice laws be made by, or in the name of, the state licensing board; but from the nature of the case the complaints must come from those who are cognizant of the facts, and prosecutions may be started by any citizen. The proper method generally is for the person having the needed information to send the facts to the state board having supervision of the matter.

57 People ex rel. Lederman $\mathrm{v}$.

Warden of City Prison, $152 \mathrm{~N}$.

Y. Sup. 977. 


\section{CHAPTER IV.}

\section{LIABILITIES.}

$\S 45$. The Contract of a Veterinarian.

\$4. Obligation to Attend.

$\S 47$. Number of Calls.

$\$ 48$. Gratuitous Service.

$\S 49$. Ordinary Liability.

$\$ 50$. Errors of Judgment.

$\$ 51$. Liabilities for the Acts of Others.

$\S 52$. Liability of Partnership.
$\S 53$. Survival of Action.

$\S 54$. Cases of Malpractice.

$\S 55$. Liability for Accidents.

$\S 56$. Special Liability.

$\S 57$. Burden of Proof.

$\S 58$. Defenses.

$\S 59$. Liability for Operation.

$\S 60$. Liability Under Enactments.

45. The Contract of a Veterinarian. In assuming the practice of a profession it must be remembered that with the privileges one also takes upon himself certain duties and liabilities. When a veterinarian answers a call and goes to see a sick horse or cow he thereby enters into an assumed contract with the owner of the stock. On his part the veterinarian warrants:

That he is legally qualified to practice his profession.

That his educational training and experience enable him to treat the case in accord with the known facts of the science.

That he will continue in his care of the case, and render such service as may be needed until the case shall be terminated, either by the death or recovery of the patient, or by the proper severing of the relationship existing between the veterinarian and the owner. 
That he will use approved methods of practice.

That he will use due care and diligence.

Unless especially provided, the veterinarian will not be deemed to have guaranteed a cure. (\$ 70.)

On his part, the owner of the stock agrees:

That he will follow all reasonable directions of the veterinarian, and render such assistance as may be possible; and

That he will pay the veterinarian such reasonable fee as would be approved considering the services rendered and the customs of the community.

46. Obligation to Attend. Unless the veterinarian holds an official position, or his call to render professional service depends upon some previous contract or agreement, he is under no obligation to respond. ${ }^{1}$ The cases cited refer to medical practice among human beings, but this makes the law all the more clear, for the plea of human life is stronger than that relative to the life of the lower animals. In the case of Hurley v. Eddingfield, ${ }^{2}$ it was claimed that the physician called declined to come, and that no other physician could be obtained, and that in consequence of the refusal of the physician the patient died. The court said: "In obtaining the state license to practice medi cine, the state does not require, and the license does not engage, that he will practice at all or on other terms than he may choose to accept."

47. Number of Calls. Having responded to the

1 Wharton, Negligence, 731; Becker v. Janiski, 15 N.Y.Sup. 675, $27 \mathrm{Abb}$. N. C. 45; Harris v. Woman's Hospital, $14 \mathrm{~N}$. Y.
Sup. 881; Hurley v. Eddingfield, 156 Ind. 416,59 N. E. 1058, 53 L. R. A. 135.

2156 Ind. 416, ete. 
call it is presumed that the physician has agreed to render such service as may be needed in a reasonable care of the case. Unless there is an agreement to the contrary, it depends then upon the practitioner to determine when, how often, and how long continued, he shall call upon the patient. ${ }^{3}$ In determining whether a patient has sufficiently recovered to require no further medical or surgical attention, a physician is required to exercise reasonable and ordinary care and skill, and to have regard to, and take into account, the well settled rules and principles of medical and surgical science. ${ }^{4}$ It is not, however, to be presumed that having assumed the care of a case either that the practitioner cannot surrender it, or that the responsible party may not discharge the medical man; however, in either case it is presumed that due and timely notice will be given. ${ }^{5}$ If a physician, or a veterinarian, desires to discharge himself from a case in which he is serving, his notice should be given in sufficient time so that the services of another may be secured. Reasonable notice, then, would be very different according to circumstances. "A physician who undertakes the treatment of a patient is bound to exercise not only the skill required, but also care and attention in attending his patient until he notifies the patient that his professional relations are terminated. * * * And when a physician is employed to

3 Barbour v. Martin, $62 \mathrm{Me}$. 536; Becker v. Janiski, 27 Abb. N. C. 45,15 N. Y. Sup. 675 ; Ebner v. Mackey, 186 Ill. 297 ; Lawson v. Conaway, 37 W. Va. 159,16 S. E. 564,18 L.
R. A. 627,38 Am. St. R. 17.

4 Mucei v. Houghton, 89 Iowa 608,57 N. W. 305.

5 Lathrope v. Flood, 63 Pac. 1007, 135 Cal. 45S, 67 Pac. 683. 
attend upon a sick patient his employment continues, while the sickness lasts, and the relation of physician and patient continues, unless it is put an end to by the assent of the parties, or is revoked by the express dismissal of the physician." 6

While the general rules would be the same for human practitioners and for veterinarians, this rule of continuance of service should not be so rigidly applied in the case of the veterinarian, especially where the number of competent veterinarians is relatively small. Human life has a theoretical value far above that of animals. However, in a New York case this doctrine was applied in veterinary practice. It was an action by the veterinarian to recover for his services in attending a horse. The testimony showed that at the time of the plaintiff's last visit the horse was very ill, and plaintiff promised to call again early the next morning. He did not return, and the horse died. The court held that evidence sustained the claim of negligence. ${ }^{7}$

48. Gratuitous Service. "Whether the patient be a pauper or a millionaire, whether he be treated gratuitously or for reward, the physician owes him precisely the same duty and the same degree of skill and care. He may decline to respond to the call of a patient unable to compensate him; but if he undertakes the treatment of such a patient he cannot defeat a suit for malpractice, nor mitigate a recovery against him, upon the principle

B Gerken v. Plimpton, $70 \mathrm{~N}$. Y. Sup. 793 ; Potter v. Virgil, 67 Barb. 578.
7 Boom v. Reed, 69 Hun. 426, 23 N. Y. Sup. 421. 
that the skill and care required of a physician are proportionate to his expectation of pecuniary recompense. Such a rule would be of the most mischievous consequence; would make the health and life of the indigent the sport of reckless experiment and cruel indifference."' 8 In one case it was held that where services are rendered gratuitously physicians are liable only for gross negligence. ${ }^{9}$ These two cases should be read together, for clearly both of them are just. The poor man should not be subject to wanton experimentation; on the other hand a physician giving gratuitous service should have more of the benefit of the doubt where there is a question as to his negligence.

Similar rules apply in veterinary practice. A competent veterinarian, trying to aid a poor neighbor by giving him professional service, should not be held so strictly to account for failure to keep watch of the case, as where he has been definitely employed. In other words, the fact that he has given one call should not, in the absence of clear evidence to the contrary, presume to be the assumption of a contract in which he agrees to continue to give his service without compensation. The contract presupposes two sides, and such a contract would have only one side. On the other hand, simply because he is giving his service does not entitle the veterinarian to experiment at the expense of his poor neighbor, and if there has been any gross negligence, or a clear departure

8 Beeker v. Janinski, 15 N. Y. Sup. 675, 27 Abb. N. C. 45.

a Ritchey v. West. ¿3 Ill.
385. Shearman \& Redfield, Negligence, 432. 
from ordinary practice, he should be held liable for harm resulting. In an Iowa case a veterinary student attempted to operate upon the shoulder of a horse. He was sued for malpractice, and was at first held liable for the damage inflicted, although it was shown that he had not expected to receive pay for his services; but on a rehearing the decision was reversed, because it was proven that his services were rendered, under protest, at the earnest request of the owner of the colt. It was shown by the testimony offered that the student had called attention to his incompetence, being still an undergraduate. ${ }^{10}$

The general rule of law is thus stated by $\mathrm{Mr}$. Cooley: "When friends and acquaintances are accustomed to give, and do give, to each other voluntary services without expectation of reward, either because other assistance cannot be procured, or because the means of parties needing the help will not enable them to engage such as may be within reach, the law will not imply an undertaking for skill, even when the services are such as professional men alone are usually expected to render. *** But when one holds himself out to the public as one having professional skill, and offers his services to those who accept them on that supposition, he is responsible for want of the skill he pretends to, even when his services are rendered gratuitously."

In 1856 in a suit for malpractice against a veterinarian in Indiana the jury were instructed in the

10 Morrison v. Altig, $134 \mathrm{~N}$. W. 529, reversed on rehearing,

157 Iowa 265, 138 N. W. 510. 11 On Torts, p. 779. 
trial court that if the defendant pretended to no skill as a farrier, or was not known as such, but as a matter of friendship, or otherwise, recommended the making of the puncture in question, and it was assented to by plaintiff, and made accordingly, defendant was not liable, though the horse died in consequence thereof. But on appeal, the supreme court found this instruction erroneous, and held that the defendant was a mandatory, and was responsible as such for gross ignorance or gross negligence; also that the diligence required is proportional to the value of the property bailed, or to the delicacy of the operation to be performed. ${ }^{12}$

The foregoing cases should make incompetent persons more cautions in assuming such responsibilities. It is unfortunately true, however, that it is just such persons who are ignorant even of the risks which they assume.

49. Ordinary Liability. "A veterinary surgeon, in the absence of a special contract, engages to use such a reasonable skill, diligence, and attention as may be ordinarily expected of persons in that profession. He does not undertake to use the highest degree of skill, nor an extraordinary amount of diligence." ${ }^{13}$ He must follow usual methods. ${ }^{14}$ He would not be held liable for failure, unless it were dne to default in duty. ${ }^{15}$ The

12 Conner v. Winton, 8 Ind. 315, 65 Am. St. Dec. 761.

13 Barney v. Pinkham, 29 Teb. 350,45 N. W. 694,26 Am. St. R. 389.

14 Patten v. Wiggin, 51 Me. 594, 81 Am. Dec. 593; Carpenter v. Blake, 60 Barb. 488.
15 Patten v. Wiggin, 51 Me. 594; O'Hara v. Wells, 14 Neb. 403, 15 N. W. 722; Bronson v. Hoffman, 7 Hun. 674; Boldt v. Murray, 2 N. Y. 232; Craig v. Chambers, 17 Ohio 253; Williams v. Poppleton, 3 Ore. 139. 
standard of skill must be judged according to the locality and time. ${ }^{16}$ It is very evident that practice which would have been approved thirty years ago would often be held gross negligence in the present condition of the science. There was a time when the use of olive oil in large doses was considered by very many practitioners as proper for the treatment of gall stones in human beings; and good men were misled into thinking that the resulting lumps of soap which were passed by the patients were really softened gall stones; yet, as we have seen ( $\$ 38$ ) this claim was the basis for the revocation of a physician's license in Texas. ${ }^{17}$

50. Errors of Judgment. It is a general rule that a practitioner is not liable for a simple error of judgment. ${ }^{18}$ But an error of judgment must not be based upon ignorance. It is to be presumed that the judgment has been formed based upon a knowledge of the sciences involved, and ignorance is not "error of judgment." 19 This rule applies to those who attempt to practice without possessing the ordinary qualification of the profession. So a druggist was held liable for malpractice in

16 Smothers v. Hanks, 34 Ia. 286, 11 Am. Rep. 141; Almond v. Nugent, 34 Ia. $300,11 \mathrm{Am}$. R. 147; Peck v. Hutchinson, 88 Ia. 320,55 N. W. 511 ; Gramm v. Boener, 56 Ind. 497; Whitesell v. Hill, 66 N. W. 894 ; Small v. Howard, 128 Mass. 131; Hathorn v. Richmond, $48 \mathrm{Vt}$. 557.

17 Berry v. State (Tex.), 135 S. W. 631.
18 Tefft $v$. Wilcox, 6 Kas. 46; Wells v. World's Dispensary Med. Assn., 9 N. Y. 452 ; Heatl v. Glisan, 3 Ore. 64; Graham v. Gautier, 21 Tex. 111; Gore v. Brockman, 138 Mo. App. 231, 119 S. W. 1082; West v. Mar. tin, 31 Mo. 375; DuBoise v. Decker, 130 N. Y. 325.

19 Courtney v. Henderson (Marine Court, New York). MeClelland, Civil Malpractice, 273. 
attempting to treat an injured finger. ${ }^{20}$ The same rule would apply here as in other cases of negligence. Thus in Cleveland v. Spier ${ }^{21}$ the defendants were held liable for an injury to an eye, while drilling into a gas main, because they did not use the improved methods of drilling or screening, which would have avoided the accident. If the practitioner called does not possess the required knowledge or skill, it is then his duty to call competent assistance, or resign the case. ${ }^{22}$ " An error" in judgment, of a man skilled in a particular calling, is not malpractice, unless it is a gross error. But error in judgment in a science, of a man unskilled in that science (if such a thing can be), is malpractice. In other words, a person attempting to practice, in physic or surgery, without first having obtained a knowledge of such science, is liable for all the damage that is the result of his practice." 23

The science of medicine has made tremendous advances within the past few years. New and powerful aids for combating disease have been furnished in the various sera, and antitoxins, and bacterins. But with these new remedial agents come new responsibilities. The man who uses them recklessly or carelessly is an enemy to the interests which he serves, and to the profession to which he claims to belong. If in administering an anthrax preventive he uses a bowl kept

20 Nelson v. Harrington, 72 Wis. 591 .

2116 C. B. (N.S.) 399, cited by McClelland, Civil Malpractice, 508 .

22 Pepke v. Grace Hospital.
Mich. 90 N. W. 278 ; Burnham v. Jackson, 1 Colo. App. 237.

23 Courtney v. Heuderson. McClelland. Civil Malpractice, 273. 
in the stable, and unsterilized, he deserves severe punishment if tetanus develops generally among his patients. Thirty years ago this would not have been considered as necessarily carelessness. Today it is criminal negligence. He should know what he is doing.

This new method imposes another duty upon the physician, whether he treat human or fourlegged animals. He must use due care in the selection of his bacterial remedies. He should assure himself that the manufacturers whom he patronizes use proper care. It is true that all these substances are manufactured in this country under governmental supervision, when they are to enter into interstate commerce. It is, however, impossible for the government to warrant their purity. A firm may get a license, and may still show carelessness in their product. This has been demonstrated several times within a few years. It therefore becomes necessary that the veterinarian who uses an anti-hog-cholera serum, for example, should assure himself that the firm manufacturing the serum is careful and in every way reliable. Cheap goods generally mean a lack of care, but high price alone is not the only guaranty necessary. A firm which has once put out impure goods should always be regarded with suspicion, unless it has been definitely and clearly demonstrated that it was the result of an accident which could not have been foreseen. See $\$ \S 157-159$.

51. Liabilities for the Acts of Others. "A physician is not responsible for the acts of nurses and interns in a hospital in dressing the wound of the patient there operated on by the physician, where 
they are not his employees unless he is negligent in permitting them to do so." 24 This is a general rule, applicable in public hospitals, or in private hospitals which are not under the control of the physician or surgeon in the case, ${ }^{25}$ but, since veterinary hospitals are seldom if at all public in ownership and control, this rule has less application in veterinary practice in hospitals. It does apply in private practice. It is the duty of a physician to give proper instruction for the care and nursing of his patient, but it is not his duty to do the nursing. ${ }^{26}$ It then becomes the duty of the owner of the animals under treatment to furnish the needed care and attendance, and negligence on the part of such attendants could not be properly charged to the attending veterinarian.

When, however, the negligence of the attendant is the result of the neglect of the attending physician to give proper instructions, even though the attendant may have been hired by the patient, or, in the case of animals, by the owner, the physician or veterinarian may properly be held for the negligence. It is the duty of the physician to give proper directions for the care of his patient. ${ }^{27}$

Where the physician or veterinarian is responsible for the liire and control of assistants, under the rule of respondeat superior he would be liable for their acts of nonfeasance, malfeasance, or misfeasance, in so far as injury might

24 Reynolds v. Smith, $127 \mathrm{~N}$.

W. 192, 148 Iowa 264.

25 Perionowsky v. Freeman, 4

Foster \& Finlason, 977.

26 Graham v. Gautier, 21
27 Carpenter v. Blake, 60 Barb. 488; Pike v. Honsinger, 155 N. Y. 201; Beck v. German Klinik, 78 Iowa 696. Tex. 111. 
result therefrom. In other words, when an animal is taken to a veterinary hospital for treatment the management of the institution will be held responsible for all that transpires there, where injury results either from negligence, carelessness, or malpractice.

A surgeon of a railroad, or a family physician is not held liable for the malpractice of another physician called in his absence, though he may have recommended that in case of need such other physician be called, when the physician called is an independent practitioner, not in the employ or partnership of the first. ${ }^{28}$ Neither is one physician or surgeon to be charged with the negligence or malpractice of an associate. Thus in a case where two physicians were in attendance, and one was discharged after the first day, the one discharged could not be charged with the negligence of the other; nor could he be himself chargerl with negligence in the case, where, having once been discharged in favor of another, he refused to attend at the later request of the patient. ${ }^{29}$ Nor should a partner be charged with the act of his co-partner, where the latter goes outside of the legitimate scope or limit of the partnership, by performing a wanton or willful act which in reason the partner would not countenance or ratify. ${ }^{30}$

52. Liability of Partnership. Under the general law relative to partnerships, the members

28 Hitcheock v. Burgett, 38 Mich. 501; Myers v. Holborn, 58 N. J. J, 193.

29 Tomer v. Aikin, 126 Iowa 114, 101 N. W. 769 . 
of the firm will be jointly liable for the acts of the others within the terms of the partnership. This includes acts of omission or of commission. ${ }^{31}$ But, where the act complained of occurred before the partnership was formed, the new physician in the case will not be held liable, and the first in attendance must bear the entire liability. ${ }^{32}$ The rule as to agency will hold the superior liable for the act of a physician sent by another to attend a case for him, or under his direction, where the service of the second physician is rendered purely as the outcome of relationship between the two, and not amounting to a partnership.

53. Survival of Action. Under the old civil law practice, actions in tort, which include suits for malpractice, do not survive the death of either party. There has been a tendency, however, to base malpractice suits upon the idea of contract, and in actions on contract it has frequently been admitted that the administrator or executor of the deceased's estate may take the place of the deceased in the case. However, it has frequently been held that an action for malpractice does not survive the death of the physician. ${ }^{33}$ While recognizing the contractual relation existing between the physician or surgeon and his patient, we must also remember that the contract is an assumed con-

31 Hancke v. Hooper, 7 Car. \& P. 81; Landon v. Humphrey, 9 Conn. 209; Tish ๙. Welker, 7 Ohio N. P. 472.

32 Hyrne v. Erwin, 23 S. C. 226, 55 Am. R. 15.

33 Boor v. Lowery, 103 Ind.
468, 53 Am. St. R. 519, 3 N. E. 151; Jenkins v. French, 58 N. H. 532; Best v. Vedder, 58 How. Prac. 187; MeCrory v. Skinner, 2 Ohio Dec. 268; Wolf v. Wall, 40 Ohio 111. 
tract, and that the death of the practitioner practically removes the opportunity for learning the essential facts from the practitioner's standpoint. In one case action was brought several years after the accident, in which the patient was thrown out of a fast moving vehicle around a telegraph post. She received numerous fractures of different parts of the body, and for a few days the surgeon did not expect to save her life. The case was one of very great difficulty, and was cared for in the country some distance from competent assistance. After the death of the surgeon and his wife suit was begun against his estate. There was no one living who was a competent witness in behalf of the estate as to facts. Even the consultant surgeon had died. Though the attending surgeon had given, in the presence of the writer, an account of the early progress of the case, this evidence was worthless in court. Plainly, the case was one in which to permit the suit to be conducted would be to take advantage of the helplessness of the surgeon's children, after he had served the patient most faithfully and intelligently.

54. Cases of Malpractice. In the absence of a formal contract the law implies a promise to compensate; and hence in such a case, the physician or surgeon must exercise ordinary skill in rendering his services. ${ }^{34}$ Where a physician, by a slip of the pen, makes a mistake in writing a prescription, as the result of which the patient dies, the fact that the druggist who filled the prescription

34 Peck v. Hutchinson, 88

Iowa 320,55 N. W. 511. 
is also negligent is no defense in an action against the physician for malpractice. ${ }^{35}$

A veterinarian, preparatory to cauterizing a spavin, so carelessly threw the animal as to rupture its diaphragm, from which injury it died. The throwing of the animal was held to constitute a part of the treatment, and negligence therein entitled the plaintiff to recover therefor. ${ }^{36}$

A veterinarian in Maine was sued for the death of a colt after gelding. The fact that two other colts of about the same age died at about the same time following the performance of the operation by the same veterinarian would suggest some lack of skill or care on his part, though the evidence was not complete with regard to those cases. However, it was held by the court that it is the duty of a veterinarian, after gelding a colt, to give such additional care as the case may require to insure good results. ${ }^{37}$ An operation is not finished until the patient has recovered from its performance, so that no further results may occur. Even when an operation has been skillfully and scientifically performed, there is still abundant opportunity for infection to occur until after the wound has healed; and when infection does occur it may be exceedingly difficult to determine whether the infection is the result of a lack of care in the operation itself, or in the after care of the animal. In either case the operator may be held liable. A payment of his fee at the time of the operation

35 Murdock v. Walker, $13 \mathrm{Ill}$. App. 590.

36 Staples v. Steed. 167 Ala.

241, 52 So. 646. 37 Williams v. Gilman, 71
Me. 21. 
would not be considered as a release from liability, unless such release were clearly indicated. It follows, therefore, that after an operation the surgeon should be watchful for the slightest evidence of unfavorable results. This is especially necessary in the care of animals, for those responsible for their care are frequently unfitted, through lack of special education, to detect and appreciate early symptoms of trouble.

55. Liability for Accidents. In veterinary practice it is quite common, in order to reduce the expense of treatment, that the owner of the animal treated furnishes needed assistance to the veterinarian, either personally, or by the aid of his regular helpers. In case of accidents the question arises, Who is liable? A physician is liable to his assistants if he assures them that there is no danger, and by virtue of trusting to his professional knowledge harm results, such as becoming infected with a disease. ${ }^{38}$ When the assistant has been warned of the danger it would be generally held that he was guilty of contributory negligence, and the veterinarian or physician would be freed from liability. A hospital was held liable for the diphtheria which the nurse contracted from one of her patients, it being shown that cultures taken showed that the first case was one of diphtheria, but the nurse was not informed of the fact. ${ }^{39}$

A physician or surgeon is held liable if it be

38 Spa v. Ely, 8 Hun, 255; 39 Herrett $\mathrm{v}$. Woman's HospiEdwards v. Lamb, 69 N. H. tal Aid Assn., 73 N. H. 556. 599,45 At. 480,50 L. R. A. 160. 
shown that through his negligence an infectious disease was conveyed to another patient. ${ }^{40}$

56. Special Liability. It sometimes happens in accident cases that an animal is so seriously injured as to be worthless. Bystanders urge that it be put out of its misery, and the veterinarian is called upon to render this service. In case the owner is present and gives his consent there is no question of the legal right; but where the owner is absent a veterinarian so acting does it at his own risk. If the street car, for example, which has done the injury represents a liability of the corporation for the damage done, a representative of the company may take the responsibility for the destruction of the animal. Where further investigation shows that the employees of the corporation were not negligent, or that there was contributory negligence on the part of the owner of the animal, such an order of the representative of the company might be taken as an acknowledgment of liability on the part of the company; or it might be held that he acted without authority. In the latter case he counsels a destruction of property not his own, and such illegal act would be no protection for the illegal act of the veterinarian in committing the deed.

The common law of humanity might justify putting the animal out of its misery; but if it be later shown in trial of the case that the killing was unnecessary, the veterinarian might be held for the destruction of the animal. ${ }^{41}$ A policeman may,

40 Piper v. Menifee, $12 \mathrm{~B}$. Mon. 465; Helland v. Bridenstine, 55 Wash. 470, 104 Pac.

626. 
or may not, have authority to order the killing. If he has the authority the veterinarian acting under such orders would be protected; but if he does not have the authority the veterinarian acts at his own peril. The veterinarian may know that the killing is justifiable, but he must be prepared to make proof of the fact which will convince the court in the face of conflicting testimony. It is ordinarily considered that a horse with a broken leg is useless and without value, but this is not always true. The writer once had a valuable colt whose hock was broken squarely across. Nevertheless complete union occurred, and the horse did many years of hard service, and was locally known as a fast, long distance roadster, and he never showed lameness. A mare, though lame from the fracture of a small bone, was still of value for breeding. In either case, had a veterinarian taken the responsibility of killing the animal, he would have assumed a liability for its loss.

57. Burden of Proof. It is a general rule of law that the one making a claim must prove it. The fact that a man is practicing veterinary medicine would be generally taken as an evidence of his competency in that profession, aside from the question of his right to practice. In his care of the case the law presumes that he has used due care and diligence, in accord with the state of the science. He is not generally called upon to prove that he is competent, but it becomes the duty of one claiming to have been injured through his malpractice or negligence to prove the fact to the jury. When he has introduced evidence to show negligence or malpractice the defendant has an 
opportunity to present his evidence to the contrary. The question of malpractice is one of fact, and the burden of proof is upon the plaintiff. ${ }^{42}$

58. Defenses. It is no defense in a suit for malpractice, that the practitioner was practicing illegally, unless, sometimes, this illegal practice was known to the person so employing him. ${ }^{43}$ "However, if the party employ a person as a surgeon, knowing him not to be one, he has no civil remedy." 44 In a suit against a veterinarian for unskilled treatment, it appeared that the defendant had sued plaintiff for the services rendered, and that the plaintiff had, without protest paid the bill before suit was entered. However, the court held that this settlement was no bar to suit for malpractice. ${ }^{45}$ In a number of cases it has been held that if suit has been brought for fees a judgment for the physician will bar future suits for malpractice, even when the claim of malpractice has not been made in defense of claim for fees; ${ }^{46}$ but in other cases it has been held that a suit for fees will not bar future damages suits, unless the claim of malpractice shall have been raised in the action for fees. ${ }^{47}$

42 Chase v. Nelson, 39 Ill. App. 53; Winner v. Lathrop, 67 Hun, 511; Haire v. Reese, 7 Phila. 138; Georgia N. R. Co. v. Ingram, $114 \mathrm{Ga}$. 639; Styles v. Tyler, 64 Conn. 432. 43 Musser's Exr. v. Chase, 29 Ohio 577.

44 Chitty's Blackstone (1858) B. III, 122, note, citing cases. 45 Deeres v. Lockhart, $51 \mathrm{~N}$. Y. Super. Ct. 302 .
46 Gates v. Preston, ${ }^{* 41}$ N. Y. 113 ; Blair v. Bartlett, 75 N. Y. 150; Bellinger v. Craigue, 31 Barb. 534; Ely v. Wilbur, 49 N. J. L. 685 ; Dale v. Donald. son Lumber Co., 48 Ark. 188, 2 S. W. 703.

47 Ressequie v. Byers, 52 Wis. 650 ; Lawson v. Conaway, $37 \mathrm{WV}$. Va. 159; Goble v. Dillon, 86 Ind. 327 . 
There is a well understood principle in the law of negligence, that if the patient, or party complaining, has failed to follow the directions given, or by his own wilful or negligent act, causes, or contributes to, the condition complained of, his action is barred. ${ }^{48}$

The cases of Morrison v. Altig, and Conner v. Winton, above cited, both involve the subject of bailment. (Chapter X.) Where a stock owner, knowing that the man to whom he entrusts the care of his animals is not competent, unless the man thus employed, or thus assisting, be grossly careless, when harm results the responsibility must be placed upon the shoulders of the owner thus making a choice involving the risk. This subject is thus discussed by Mr. Justice Story in his Commentary on "Bailments": ${ }^{49}$

"But even where the particular business requires skill, if the bailee is known not to possess it, or he does not exercise the particular art or employment to which it belongs, and he makes no pretension to skill in it; then, if the bailor, with full notice trusts him with the undertaking, the bailee is bound only for a reasonable exercise of the skill which he professes, or of the judgment which he can employ; and if any loss ensue from want of due skill, he is not chargeable. Thus (to put a case borrowed from the Mohammedan law), if a person will knowingly employ a common mat maker to weave or embroider a fine carpet, he may

48 . Tones v. Angell, 85 Ind. 376; Lower v. Franks, 115 Ind. 334, 17 N. E. 630; Hibbard v. Thompson, 109 Mass. 286;
Hitcheock v. Burgett, 38 Mich. 501 ; Littlejolnn v. Arbogast, 95 111. Ap]. 505. 49453. 
impute the bad workmanship to his own folly. So, if a man, having a disease in his eyes, should employ a farrier to cure the disease, and he should lose his sight by the remedies prescribed in such cases for horses, he certainly would have no cause for complaint."

59. Liability for Operation. In submitting a case to a physician, surgeon, or veterinarian, there is implied a tacit agreement that the professional man shall use his best knowledge and treatment, and this implies also an agreement to submit to such operative measures as seem to him necessary. ${ }^{50}$ Whenever an operation is not anticipated by the owner of an animal which is submitted to the care of a veterinarian he should inform such owner before performing the operation, unless the conditions are such that it is impossible to reach the owner without jeopardizing the life of the animal. Also, if one operation has been contemplated and on examination a more serious operation seems indicated, he should delay the operation until the owner can be communicated with, and his consent secured. However, having begun the operation, when it is found that a more extensive operation seems indicated, to then delay the completion of the needed work might increase the danger, and the operator would not be expected to wait for the further consent.

60. Liability Under Enactments. No man has a right to break the laws under which he is living. Incidentally to his professional work a vet-

\footnotetext{
50 State ex rel. Janney v. Div. 44, Cent. L. J. 153; McHousekeeper, 70 Md. 162; Clallen v. Adams, 36 Mass. 333.
} Beatty v. Cullingsworth, Q. B. 
erinarian may subject himself to penalties under enacted statutes or ordinances. Thus, where a local law gives a body or an officer the authority to prevent cruelty to animals, and a man has been legally ordered not to work a horse, a veterinarian who advises the owner that the horse may be worked may thereby incur the penalty. That is a question of opinion with the veterinarian, but he has not the legal authority to decide the question of fact. 


\section{CHAPTER V.}

\section{COMPENSATION.}

$\S 70$. Employment Under Contract.

$\S 71$. Competency.

$\S 72$. Right to Sue for Fees.

\$ 73. Illegal Practitioners.

$\S 74$. Effect of Malpractice on Compensation.

\$ 75. Who Is Liable for Compensation.

876. Amount of Compensation.

$\S 77$. Use of Mails.

$\$ 78$. Liens.

\$ 79. Veterinarian a Bailee.

$\S 80$. Contract and Lien.
$\S 81$. Nature of a Lien.

$\$ 82$. Voiding a Lien.

\$83. Lien Not a Right to Sell.

$\S 84$. Actions for Recovery of Compensation.

$\S 85$. The Veterinarian as a Witness.

\$ 86. Duty to Prepare.

$\$ 87$. Expert Testimony.

$\S$ S8. Definition and Scope of Expert Testimony.

89. Compensation as an Expert.

70. Employment Under Contract. When a veterinarian has been called to render professional service, and he has responded to the call, under ordinary circumstances it is legally understood that the parties have entered into an implied contract. On his part the veterinarian agrees to attend the case until the case is ended by deatl or recovery, or by the termination of the relationship through the proper notice from either party to the other; and, to give due and diligent professional service. On the part of the employer there is understood to be an agreement to pay a reasonable fee for the services rendered. Any variation from these terms should be clearly understood by agreement between the parties before service is rendered, and if other responsibilities 
be added on either side there should be a definite agreement in writing. For example: It is not ordinarily understood that there is any warranty on the part of the physician or surgeon as to the results of his services, not even that they will be beneficial. ${ }^{1}$ A conditional contract between a patient and his physician, that if the physician effect a cure he should receive a reasonable compensation, is valid. ${ }^{2}$

71. Competency. Where there is no law regulating the practice of veterinary medicine it has been held, in an action to recover for professional services, that the plaintiff must prove his qualifications as a veterinarian. ${ }^{3}$ In other words, where the law imposes no restriction or qualification in the practice of the profession, the fact that a man renders a service is not of itself evidence that he is entitled to compensation as a veterinarian. He might be regarded as simply entitled to compensation for his labor, and not for professional opinion and knowledge.

Where the law regulates the practice, by requiring either registration or license, there has been some difference of interpretation as to requirements in suits for professional fees. Thus, in England it has been held that the fact that an apothecary's assistant had been paid for medicines could not be considered as proof that he was

1 Tefft $\nabla$. Wilcox, 6 Kas. 46; Styles v. Tyler, 64 Conn. 432, 30 Atl. 165; MeCandless v. MelWha, 22 Harris (Pa.) 261; Gallaher v. Thompson, Wright (Ohio) 466; Hancke v. Hooper,
7 Carr. \& P. 81; Patten v. Wiggin, 51 Me. 594.

2 Mock v. Kelly, 3 Ala. 387.

3 Conkey v. Carpenter, 100 Miclı. 1, 63 N. W. 990. 
practicing as an apothecary. ${ }^{4}$ The onus of proof is upon the holder to show that he has a license. ${ }^{5}$ Similarly in this country it has been held that a physician or surgeon cannot recover pay for his services without proof of his license to practice. ${ }^{6}$ However, it has also been held that the fact of his employment is a recognition of his capacity, relieving him, in an action to recover for his fees, of the duty of producing his license, and throwing the burden of proof upon the defendant. ${ }^{7}$ Both of these opinions should be taken together in order to get a reasonable interpretation. The fact of employment should be accepted as an evidence of the legal competency of the practitioner, and the defendant in a suit for fees should not be permitted to impede justice by setting up a technical objection, forcing the plaintiff to produce his license, or evidence of registration. If he undertakes to avoid payment of his obligation by claiming that the practitioner is not legally qualified, he should be forced to present evidence to that effect. It would then become incumbent upon the plaintiff to produce the license itself ( $\$ 37$ ), or, where registration only is required, to produce evidence that he had legally been registered.

72. Right to Sue for Fees. According to the old English custom a physician was supposed to "give" his services, and his clients returned the

4 Brown v. Robinson, 1 C. \& P. 264 .

5 Apothecaries' Co, v. Bent. ley, 1 C. \& P. 538.

6 Adams' Adm. v. Stewart, 5
Har. 144; Bower v. Smith, 8 Ga. 74.

7 Prevosty v. Nichols, 11 Mart. O. S. 21; Dickenson v. Gordy, 5 Rob. (La.) 489. 
favor by "giving" him an honorarium. A surgeon was considered to be on a lower plane. According to the old common law therefore a surgeon could sue for fees, and be prosecuted for malpractice, but the physician was not liable for malpractice, ${ }^{8}$ nor even for manslaughter when his patient died, ${ }^{9}$ as a result of his treatment. However, if one claimed to be a physician or surgeon when he was not, and harm resulted from his service, he might be prosecuted criminally for the harm done, and sued for civil damages. ${ }^{10}$ On the supposition that his compensation was simply an honorarium a physician could not bring action therefor. ${ }^{11}$ However, the right of physicians and surgeons, including veterinarians, to bring action to recover for their services has generally been recognized by the common law in the United States. ${ }^{12}$

73. Illegal Practitioners. Where the law requires registration, a physician who has failed to register cannot recover for professional service rendered. ${ }^{13}$ Where the law requires physicians to obtain a license, an unlicensed physician cannot recover for services rendered. ${ }^{14}$ A promise to pay one practicing illegally is void. It is a contract void in its inception. ${ }^{15}$

\footnotetext{
8 Chitty's Blackstone, III, N. J. L. 60 ; Judah v. Me122, note. But see, IV, 197, Namee, 3 Blackf. 269. note. 13 Murray v. Williams, 121

9 Chitty's Blackstone, IV, Ga. 63, 48 S. E. 686. 197. 14 Orr v. Meek, 111 Ind. 40, 10 Chitty's Blackstone, IV, 11 N. E. 787. 197 , note. 15 Puckett v. Alexander, 102 11 Chitty's Blackstone, III, N. C. 95,8 S. E. 767,3 L. R. 28 , note.

A. 43 ; Coyle v. Campbell, 10

12 Green v. Higenbotam, 3 Ga. 570; Underwood v. Seott,
} 
74. Effect of Malpractice on Componsation. Negligence does not necessarily preclude the recovery of fees, perhaps reduced in amount. ${ }^{16}$ It is a general rule, however, recognized by the common law, that where the practitioner. has been guilty of negligence and malpractice he cannot recover for his services. ${ }^{17}$ It must be recognized that there is a difference between simple negligence and malpractice, though malpractice is a result of negligence. It should be apparent to any one, that a man who is constantly intoxicated cannot rencler due care in such professional service; but if one continues to employ such a practitioner, knowing his habits, he is thereby estopped from making that a ground for refusal to pay for the service. ${ }^{18}$ If there be negligence on the part of the practitioner, there is also contributory negligence on the part of the client. A man cannot thus take an advantage of his own negligence.

75. Who is Liable for Compensation. Ordinarily it is the owner of live stock who sends for the veterinarian, and in such a case there would be no question as to who must pay for the services. Under the general rule of respondeat superior the act of a subordinate is considered as the act of the principal, and when a servant sends for the veterinarian it will be considered as if the owner himself had sent for him. It frequently happens in accident cases especially, that some person

43 Kas. 714, 23 Pac. 942; Maxwell v. Swigart, 48 Neb. 789,67 N. W. 789 .

16 Whitesell v. Hill, $66 \mathrm{~N}$. W.
17 Chitty's Blackstone, III, 122, note.

$18 \mathrm{McKleroy}$ v. Sewell, 73 Ga. 657 . 894. 
other than the owner either comes in person, or telephones to the veterinarian asking for his immediate service. The veterinarian is under no obligation to respond, and if he does respond he runs his own risk as to compensation. A person calling a physician to attend one for whose support he is not responsible is not liable for the payment of the services. ${ }^{19} \mathrm{He}$ is not liable for the payment unless it be distinctly' agreed between the physician and the party calling. ${ }^{20}$ Where a physician renders service to one at the mere request of a third person on whom there is no obligation to provide therefor, the law will not imply a contract binding the third person to pay therefor; but where an officer of a company directed a physician to attend an employee injured in line of duty the physician can recover reasonable compensation. ${ }^{21}$ Applying these principles in veterinary practice we might reasonably say that when the owner of an animal, or one of his employees or a member of his family, calls for the services of a veterinarian for the said animal, the owner will be considered to have entered into a contract to pay the veterinarian for his professional services. When an animal has become sick or injured, and the veterinarian has been called either by the party legally responsible for the sickness or injury, or by his legal representative, it will be presumed that the party thus legally responsible

19 Starrett v. Miley, $79 \mathrm{Ill}$. App. 658; Dorion v. Jacobsen, 113 Ill. App. 563; Kearnes v. Caldwell, 7 Ky. L. 450.

20 Grattop v. Rowheder, 1

Neb. 660,95 N. W. 679.
21 Weinsberg $\nabla$. St. Louis Cordage Co., 135 Mo. App. 553, 116 S. W. 461. 
will pay the bill. If the veterinarian has been called by one neither responsible for the condition of the animal, nor its owner or his representative, it will be presumed that the act of calling for professional aid proceeded purely from humane motives, and if the veterinarian responds he can hold no one liable, in the absence of a previous agreement. If, however, he responds, and the owner accepts his services, either by permitting him to continue, or by following his directions, or by getting a prescription filled, it will be considered that the owner thereby assumes the liability for the payment.

The case is not always so simple as it looks, and the decision as to liability for payment may hinge upon a very small item. Suppose that an automobile runs into, and injures an animal. If the accident be due to the carelessness of the owner of the animal, only the owner could be held; and not he unless by some act he puts himself under the obligation, as by calling the veterinarian or acquiescing in the treatment. But if the veterinarian be called by the owner of the automobile, not to attend to the injuries, but to determine their extent, and as a matter of defense for the motorist, clearly he would be under obligations to pay for the service thus rendered; though if the veterinarian incidentally treated the injuries the motorist would be under no obligation to pay for this extra service. The same general rules would apply in case the responsibility for the accident rests upon both the owner of the animal and the owner of the automobile.

When the accident has been the result of the 
negligence of the owner of the automobile, if the veterinarian be called by the owner of the animal he must look to said owner for his pay, although the owner may later recover from the owner of the auto. If the veterinarian be called by the owner of the auto, the owner of the auto will be expected to compensate. When called by a third person, not representative of either party, there is no obligation, in the absence of previous agreement, or of governmental enactments. In every case, the act of an employee will be deemed the act of the principal.

Dogs are legally regarded as "qualified property." ${ }_{22}$ That is, they are regarded as property only when kept within the provisions of the law. Thus, where the law calls for a license, or a collar, or the wearing of a muzzle, a violation of such provision removes the protection of the law for the animal. It has therefore been held that under such conditions there is no recovery for the killing of such an animal. ${ }^{23}$ But a dog is personal property with a value, ${ }^{24}$ so that ordinarily the liability of the automobilist would depend upon whether or not the accident was due to his carelessness. (§ 189.)

"There is nothing in the ordinary relation between a physician and his patient which would prevent the former from discontinuing his services on the account of the latter, and entering into a contract with another for the payment of the

22 Public Health, 186. 23 Sentell v. New Orleans, etc., R. Co., 166 U. S. 698. 24 Anson v. Dwight, 18 Iowa
241; Heisrodt $\nabla$. Hackett, 34 Mich. 283, 22 Am. R. 529; Nehr v. State, 35 Neb. 638, 53 N. W. 589, 17 L. R. A. 771. 
charges for his subsequent attendance, and the assent of the patient to the making of such contract is not necessary." ${ }_{25}$ This was a case in which a physician had been called to attend a man who was injured. Upon hearing of the accident, and not knowing who was in charge of the case, the man's employer telegraphed to the same physician, directing him to attend the case and implying that he wonld pay the bill. Such an order is entirely different from the ordinary call of a third person. It is not an impersonal matter, but it involves the personal obligation of the one giving the order, though put in the form of a request. No matter by whom first called, there is nothing which rould prevent a veterinarian from transferring his future charges to the account of another, when the third party thus requests.

For self protection it is quite customary among certain classes of corporations to pay for first aid for their employees, and for such as may be made ill or injured in connection with the operation of the corporation, and continuing to pay for such services until the liability of the corporation shall be shown not to exist. For example, a man is injured by a street car. A surgeon is called and attends to the case. The strect car corporation asks for a report of the injuries discorered, and pays for this first attendance. The patient is then at liberty to select whom he wishes to look after the case. If, however, it shall appear that the corporation is liable for the accident, its officers may provide their own surgeon for future service. The

25 White v. Mastin, 38 Ala. 147. 
fact that a physician or surgeon has been called in an emergency, and has rendered a service, gives him no claim upon the future of the case. If the patient, or, in the veterinary practice, the owner of the animal injured, desires to make a change in attendant he has a perfect right so to do, but he should give notice thereof to the first attendant. That such a practice exists among corporations does not place an obligation upon other corporations to do the same. Where it is a well known practice of a certain company to pay for first aid, that practice should be considered as binding upon the company until it shall give due notice of a change of method; for acting upon the custon of that company the physician, surgeon, or veterinarian might respond to a call and render service when he otherwise would not do so.

Likewise, it is the custom of certain companies to employ their own medical and surgical attendants; and in case of emergency, no matter by whom called or notified, if the company surgeon attends, the company pays the bill; but if another surgeon be called the company does not pay the bill unless it shall be shown that the company was responsible for the accident.

The call of the physician, surgeon, or reterinarian may be made by a policeman or other officer of the city. This of itself does not imply that the city will pay the bill. Unless there be some definite provision, either in the statutes of the state, the ordinance of the city, or the resolutions of the city council giving such officer authority to call such professional attendants, his act will be con- 
sidered as that of a citizen, and not of an officer..$^{26}$ Then there would be no obligation on the part of the city to pay for such service. Where the act is legally authorized by such statute, ordinance, resolution or proper regulation, the fact of calling: would impose on the city government an obligation to pay.

When a veterinarian responds to a call given by a third party, in order to charge the call, or calls, against the said third party, he should be sure that he has a definite agreement on the part of such third party to pay for the service. If possible, he should have the agreement made in writing, signed by the said third party, and the agreement should state in general terms the limits of the service required. If not in writing it should be made in the presence of one or two reliable witnesses. Many physicians carry prescription blank books with carbon sheets for the preservation of duplicates. A short order, written on such a blank, and signed by the said third party is sufficient, and the duplicate should be torn out and presented to the party so signing, for his own protection in case of a misunderstanding. Duplicate short reports of findings may be made in the same way for possible future reference in case of accidents. Where there is a possibility of future legal determination of liability these records are of the greatest importance, and negative findings are of as much importance sometimes as those which are positive. The fact that there is no record of a broken bone is not evidence that there is no such

26 Public Health, 376. 
injury, for the recorder may have forgotten to make that record, especially in the case of small bones. Or the omission may be due to the fact that the surgeon has not discovered it, becanse of his neglect. The fact that he records "no bones broken" is positive evidence as to his findings. Evidence of former injury should also be recorded. It sometimes happens that unprincipled litigants cliarge old injuries against recent accidents.

76. Amount of Compensation. The law implies an obligation to pay the reasonable value of medical services. ${ }^{27}$ In an action for services of a veterinarian, plaintiff is entitled to recover ordinary and reasonable charges usually made for such services by members of the same profession of similar standing, but it is not admissible to show what the plaintiff charged another person for similar services, according to the opinion of a southern court. ${ }^{28}$ While this might be a correct ruling relative to unusual cases, it would seem not to be justified where his charges are generally known in the community, or where his fee bill is printed, as on his billheads.

In an Arkansas case involving damages the attending surgeons were instrumental in effecting a compromise, but they were nevertheless forcerl to bring action for their services. The court said that where no amount has been agreed upon. each side may introduce evidence as to the value of the services, but it is an error to introduce evidence that the surgeons were instrumental in ef-

2: Herndon v. City of Spring. field, 137 Mo. App. 513, 119 S. IV. 467 .
28 Marshall v. Bahnsen, 1 Ga. App. 485,57 S. E. 1006. 
fecting the compromise settlement. ${ }^{29}$ It is to be presumed that they acted simply as friends in the compromise matter. Their profession is that of physicians and surgeons, and such efforts as they might have made in the compromise proceedings was plainly outside of their professional duty. Were they also lawyers, they might possibly have been entitled to compensation therefor, provided their action therein was with the knowledge and consent of the party whom they represented. It is no part of a veterinarian's professional duty to act as a lawyer to effect a settlement of a claim, though his statement of the case may have some bearing. He may, perhaps, make an extra item of a report of the extent of the injury, but such charge should be independent of any possible result of the report. It should simply state the facts, as he knows them. To receive extra compensation for effecting a compromise settlement would be to cast doubt upon the honesty of his report.

77. Use of Mails. One has no unlimited right to the use of the United States mail for the purpose of collecting his accounts. Bills, or requests for payment should not be sent on postal cards. The bill should be in a sealed envelope. Neither, even in such a sealed envelope, should there be anything which could be interpreted as a threat, or as abuse. A violation of these points creates a liability to prosecution under the national laws.

78. Liens. The question is frequently asked whether or not a veterinarian has a right to hold

29 Henderson \& Campbell v. Hall \& Hughes, S7 Ark. 1, 112 S. W. 171. 
animals treated until the bill has been paid. It must be remembered that the veterinary profession arose from the ranks of the farriers, or horseshoers, so that early decisions are based upon the work of the farrier. Also, that to no small degree the bills of the veterinarians include items for the board of the animals treated; and sometimes the board is the only item. By either common law or statute it would be quite possible for the veterinarian to have a lien on one and not on the other account. Thus, in an old English decision it was held that the farrier had a lien for curing the animal, but not for feed. ${ }^{30}$ The term "agister" (or "agistor") was originally held to mean one who took cattle, or other stock, to pasture. It is ordinarily held to include other keeping and feeding. By the old English common law an agister had a lien upon the stock in his possession for the payment of the keep of the animals, but this lien was abolished by an act of parliament. On the other hand, many American states have enacted statutes giving a right to such lien, in the case of agister's generally, and for such special occupations as innkeepers and livery keepers. (§§ 233-240.)

The right to hold an animal for both cure and board has been recognized in many cases. ${ }^{31}$ It may perhaps be stated as a general rule that the veterinarian has a lien on the animals treated so long as they are in his possession. This rule is not absolute, and is open to question. In one Canadian case the lower court held that the farrier 30 Brenan v. Currint, Say., 50; Lord v. Jones, 24 Me. 439 ; 224.

Hoover v. Epler, $52 \mathrm{~Pa}$, St.

31 Danforth v. Pratt, 42 Me. 522. 
had no lien. The higher court, in a very unsatisfactory opinion because of the lack of completeness in the records, affirmed the decision of the lower court, on the ground that the practice was open to question. ${ }^{32}$

A lien may be created by common law, by statute, or by contract. When by statute the terms of the statute must govern its application; but such a law cannot be retroactive, and thus affect previous accounts. Thus where a party kept stock for several years, and during that time a statute was enacted giving an agister a lien on the stock until the expense of the keep be paid, it was held that this lien covered so much of the account as occurred after the act was in operation, but it did not cover the previous time. ${ }^{33} \mathrm{~A}$ contract to pay for the keep of stock before it is moved creates a lien. ${ }^{34}$

79. Veterinarian a Bailee. Whenever a thing owned by one party is left in the care of another than the owner, the operation is called "bailment," the party leaving it is the "bailor," and the one receiving it is called a "bailee." Bailment, then, is a contract, in which the bailee accepts the responsibility to care for the article, often for some other purpose than the simple keeping of it safe, and to return it again to the bailor when the bailor demands it. The law of bailment is then important for the veterinarian for it includes many obligations and liabilities. The amount of his responsibility as a bailee may vary

32 Nichols v. Duncan, 11 U.

C. Q. B. 332 .

3+ $\mathrm{MeCoy}$ v. Hoek, 37 Iowa

33 Allen r. Ham, 63 Me. 532. 436. 
according to many circumstances. A fuller discussion of the subject will be found in Chapter $\mathrm{X}$.

Veterinarians know that dogs and cats are frequently left with them by humane persons, simply to assure the animals a home, and with no expectation or intention of ever claiming the animal again. Others are left in good faith when the orners are to be away from home for a time. It is often impossible for the bailee to know to which class his patron may belong. It therefore becomes important for him to protect himself.

Let us suppose a few cases: A brings a dog to the dog hospital and asks the terms for keeping it. He says that he is going away for a time and wants his dog well cared for. He states that he values the dog, on account of associations, at $\$ 1,000$. He pays for ten weeks' board and departs. The animal, we may suppose, is practically wortlless for any one else. At the close of nine months or a year, not having heard from $A$, the veterinarian concludes that $A$ has simply abandoned the (log, and order's it killed. The next day A appear's and asks for his dog, and the bill for its keep. The veterinarian cannot comply with the demand for the animal. He is then liable for the value of the dog, and in such a case the value would probably be assessed by the jury at a price nearer the appraisement of the owner than that of the bailee. Further; because the bailee failed, to keep his contract and deliver the dog, it is questionable whether any jury would permit him to deduct any amount for the board of the animal.

But if $A$, a few days after leaving the dog, should chance to meet $B$, and inform him that he 
had taken that means of abandoning the dog, he would thereby relinquish all right and title to the animal, which would thus become the property of the bailee. Could the veterinarian prove this, he clearly would not be assessed for the loss of the animal; and he might be able to collect the full amount of the board from $\mathrm{A}$ on the contract made.

80. Contract and Lien. There may be some possible question raised at settlement of account as to the purpose for which an animal was left with the reterinarian. It is the reterinarian's duty to himself to safeguard himself as much as possible. It is a custom in bailment generally for the bailee to give to the bailor some form of a receipt. It would be well for the veterinarian to do the same where animals are left with him either for board or treatment. It is customary in many veterinary infirmaries to make out a memorandum card for each patient or boarder. This may be worded as a receipt and made in duplicate and one copy given the owner. It should state the name and address given by the bailor, the number and kind of animals, or description or name of the animal left, and the purpose for which left; and such receipt should contain a statement to the effect that the animal is left in compliance with the following rules or regulations, to which it is thereby understood that the bailor, or owner, agrees. The receipt should state the terms agreed upon, or the fixed charges, and that it is understood that a lien exists upon the animal, or animals, until the bill shall be paid; or before the animal is remored all accounts must be settled. No verbal agreement, not in harmony with the receipt, has legal yalue. 
If no amount is stated in the receipt for services, it will be presumed that the charges will be reasonable.

A form of receipt may be something as follows:

Received from John Doe, 175 South street, Vincennes, a male fox terrier dog with brown right ear, (or, named "Gyp") for treatment and board, subject to the following rules and rates, to which it is understood that the owner agrees. Board, for dogs, $\$ 2.00$ per week. Professional fee table on back of receipt. All bills to be paid before removal of the animals. Animals not paid for will be sold in 6 months.

Vincennes, Ind. Signed,
April 7, 1914.
Peter Brown,
Veterinarian.

It is often advisable that other rules be given, such as that board must be paid at least every second month, and that the owner of the establishment agrees to give ordinary care, but that he does not assume liability for unavoidable accidents, etc.

81. Nature of a Lien. It is one of the essentials of a lien that it must bear some direct relationship to the thing for which it is held. A horse taken to board could not be held on account of veterinary services for cattle on the farm. There may be some question as to whether an animal may be held for any old account. The English case of Scarfe v. Morgan ${ }^{35}$ seems to support such a claim. One Scarfe brought a mare to be served on Sunday by the stallion of Morgan. Morgan held the mare,

354 M. \& W. 270. 
not only for the last service, but also for former serving of that mare and others. Scarfe made tender of the fee for last service, which was refused. He then brought action against Morgan to secure possession of the mare, or her full value. His first claim, that the contract having been made on Sunday was illegal, was put aside by the court on the ground that it was a completed contract. Scarfe then claimed that Morgan, by combining old accounts in his lien vitiated the right of lien. The court held, however, that the different servings were not independent accounts, but that each was a part of one general account, and that the lien held. ( $\$ 234$.)

82. Voiding a Lien. Possession is essential in liens. Therefore, when the veterinarian voluntarily relinquishes the possession of the animal to the owner, or to others not in his own employ, he thereby loses his right of lien, and according to the general rule a lien once lost cannot be revived. ${ }^{36}$ But where the agister temporarily left the animals in the charge of another, and during that time the owner took possession, the lien was not lost. ${ }^{37}$ It is generally held that surrender to anyone not in the employ of the holder of the lien voids its operation. (\$§ 208, 233-240.)

The right of lien may be lost by agreeing to

36 Fishell v. Morris, 57 Conn. 547, 18 AtI. 717 ; 6 L. R. A. 82; Wright $\mathrm{v}$. Waddell, 89 Iowa 350,56 N. W. 650; Danforth v. Pratt, 42 Me. 50; MePherson First National Bank v. Barse Live Stock Com. Co., $61 \mathrm{Mo}$. App. 143 ; Powers v. Botts, 58
Mo. App. 1; Kroll v. Ernst, 34 Neb. 482, 51 N. W. 1032; Cardinal v. Edwards, 5 Neb. 36. 37 Willard v. Whinfield, 2 Kas. App. 53, 43 Pac. 314; Weber v. Whetstone, 53 Neb. 371,73 N. W. 695. 
give credit. ${ }^{38}$ Or by refusal to deliver on other grounds. ${ }^{39}$ A refusal to deliver when the bailor tenders the amount legally covered by the lien serves as a waiver of the lien. ${ }^{40}$ This should be remembered in attempting to hold lien for past accounts, which the court might consider as independent matters. A notice to the owner to come and take his horse away is a waiver of lien for amounts due to the time of notice, and lien would only corer subsequent account. ${ }^{41}$ But, a notice to pay charges and remove would not be a wairer of lien. While it is presumed that the bailee will take such care of the animal as to preserve him in good condition, and that might necessitate the driving of a horse, for example, any use of the animal beyond what is necessary for the good keeping of the animal may be held to vitiate the right of lien. ${ }^{42}$

83. Licn Not a Right to Sell. The lien itself does not necessarily give the right of sale. (\$\$ 238 , 241.) Ordinarily the statutes provide for an orderly way of disposing of the property, generally by advertisement and public sale. If the bailee sells the animal, the owner may sue him for conversion, and recover the market value of the animal sold, less the charges to the time of sale. All that is received by the bailee in the sale of bailed property, more than is corered by the lien, is the

38 MeMaster v. Merrick, 41 Mich. 505.

39 Hamilton v. MIcLoughlin, 145 Mass. 20; Mexal v. Dearhorn, 12 Gray, 336.

40 Busfield $r$. Whieeler, 14 Allen (Mass.), 139.
41 Hamilton v. MeLoughlin. 145 Mass. 20 .

$₫ 2 \mathrm{~V}$ an Zile, Bailments amil Carriers, 87. 
property of the former owner; and if the animal is sold for less than market value the owner can recover the balance from the bailee. Provision may be made in the contract for the sale of property under certain circumstances, and stipulating how it shall be sold. This could well be placed in the receipt form used by the veterinarian when he receives an animal for board or for treatment.

The bailee of animals is obliged to feed them and give them good care. To preserve the lien, therefore, the veterinarian must continue to expend money in the keep of animals held.

84. Actions for Recovery of Compensation. Owing to the small amount of the bill, actions for the recovery of compensation for professional services are ordinarily brought in the courts of justices of the peace. The proceedings are frequently conducted in a very informal manner, and without attention to some of the usages of Englishspeaking courts generally. In a large proportion of the cases no attorney is present to represent either side. In case of appeal to higher courts both sides are represented by attorneys. Fxact usages differ in different sections of the country, and it is not here intended to "make erery man his own lawyer," for it is said that "a man who pleads his own case has a fool for a client." It is proper, however, to give certain general suggestions.

In an action for services the plaintiff must show to the court that the services were rendered, that the charge is reasonable, and that the defendant is liable for the payment of the same.

That the services were rendered should be shown 
by his books of original entry. Day-books, or calling lists are frequently kept by physicians, and probably also by veterinarians, in such hieroglyphic characters as to be useless in court. One mark means a call, another means an office prescription, another some surgical service, and still another means an obstetrical case. These marks must be interpreted to the court, and he cannot be sure that the meaning of certain characters has not been changed.

When a veterinarian has rendered professional service he should make such a definite record that anyone could understand what he means. "E 20 S" may be for the veterinarian's use enough to remind him that he examined so many sheep for scab, but perhaps before the suit was brought other things might have obscured the memory, and " $\mathrm{S}$ " be translated "shoats." It is not sufficient to simply record a call, the book should show just what was done. If hogs be treated for protection from hog cholera, the record should show how many, and whether the veterinarian furnished the virus, or the owner paid for it. The record should show with some definiteness just what animals were treated, and in case of the use of an unusual amount of time it should show how much. Such a record is of positive value in court. Most records made by medical men are of only possible value. The record may be made upon cards for filing, or upon loose sheets of paper. It is better made in books which will show, by the presence of other entries before and after, that it is a genuine entry, and was not made up for the trial.

Reasonableness of charge has already been 
discussed. To show the liability of the defendant it will be necessary to produce evidence of some act of the defendant, or of his representative, which demonstrates that the service was rendered with the knowledge and concurrence of the defendant.

In the statement of the case the veterinarian should begin with the declaration that he is a veterinarian (holding the required license, or duly registered, if either be required by law), of legal competence in the practice of his profession, residing, and doing business at a certain place, and that on certain dates specified he rendered certain specified services for the account of the defendant, and that for said services he demands payment of a certain reasonable sum of money, specified. Ordinarily the court will take judicial notice of the fact that the veterinarian is of legal standing as such; that is, no proof of these points will be required. If the defendant raises this point, in argument why the court should so take judicial notice attention should be brought to the fact that by his employment of the plaintiff (the veterinarian), the defendant is estopped from raising this objection, unless he presents evidence which would convince the court that the plaintiff is not legally qualified as a veterinarian. When such evidence is presented it must be combatted with positive evidence, and where a license is required the license itself must be produced. ${ }^{43} \quad(\S 37$.

It will not ordinarily be necessary to present evidence of due care and diligence, and regularity of

43 Greenleaf, Evidence, 79;

Wharton, Criminal Law, 2434 . 
practice. Where the defendant raises these questions it will be necessary to get the testimony of others, and especially of experts. In a suit for damages arising from malpractice, in which a veterinarian so negligently threw a horse as to rupture his diaphragm, it was held that a nonexpert, who had frequently seen horses hobbled and thrown during an experience of from twelve to thirteen years, was competent to testify as to the methods used. ${ }^{44}$

85. The Veterinarian as a Witness. Whether he be called as a witness of fact, or for his expert opinion, the veterinarian should be careful to make a clear distinction between fact and opinion. Judging from certain facts which he recognizes as symptoms he may form the opinion, or diagnosis. that a horse has pnenmonia; but mistakes in diagnosis have been made by good men. It is therefore taking an unnecessary risk for him to assert, even under the most persistent urging of a crossexamining attorney, that the horse has pneumonia. It is a peculiar psychologic fact that the ignorant witness is often the one who is most positive in stating his opinions as facts. He seems to attempt to supply his lack of knowledge by vehement assertions. A skillful questioner may often lead such an one into making the most ridiculous statements in regard to nonimportant matters, and thus completely upset the value of his testimony upon essential points.

The witness should simply tell the truth. $\mathrm{H}$. should be impartial. So far as possible he should

44 Staples v. Steed, 167 Ala.

241,52 So. 646 . 
avoid technical terms, speaking in the language of the court and jury, so that they may clearly understand him. If it be necessary to use technieal terms he should be sure himself to explain their meaning in order that the force of his testimony may be known. He should not attempt to impress the judge, the jury, or the spectators with his great knowledge and experience. If he attempts this he is quite likely to find himself "hoist with his own petard." He blows himself up like a balloon, which the opposing counsel takes delight in puncturing. On the other hand, it is entirely right that the facts of experience be presented to the court. A veterinarian who has practiced for ten years, especially one who has been working under the directions of the Department of Agriculture, in Oklahoma, is much more likely to know about the various phases of the Texas cattle ferer than one who has been limited in experience to private practice in New England or northern New York.

86. Duty to Prepare. No professional man should go upon the witness stand to testify as to a matter pertaining to his profession without taking the precaution to see that he is well posted, aceording to the most recent knowledge of the profession. The veterinarian should be familiar with the approved means of diagnosis, and with the later ideas in pathology, pertaining especially to that particular injury or disease which may be a subject of controversy, either directly or indireetly. It is an easy matter for an experienced lawyer, after a few hours reading of an approved texthook of medicine or surgery, to make the aver- 
age medical witness appear far more ignorant than he really is. One well posted witness is worth several men with "reputations," but who show inexactness in examination. Where a witness guesses at an answer he is very likely to greatly reaken the force of his testimony. If he does not know he should say so, and then when he says a thing it will be presumed that he knows that which he pretends to know.

It often happens that a lawyer gets from the witness an admission of a certain fact, and then asks if some other fact is not dependent upon the acceptance of the first. While such a sequence might be common, or very usual, it is unsafe for the witness to give an unqualified approval. In such cases the expression "Not necessarily" proves often exceedingly valuable.

87. Expert Testimony. Justice frequently demands that special evidence be given, of a technical nature, and that the opinion of those competent to decide as to technical points be given to the jury to enable the latter to arrive at an equable decision. Not all technical witnesses, testifying as to professional matters, are the givers of "expert testimony," irrespective of their competency to give such expert judgments or opinions. "The value of professional services is not a question of science to be proved by expert testimony." 45 Such a matter is a question of fact, to be determined by usage and circumstances. Therefore, it has been held that a person who is not an attorney is competent to prove the value of an attorney's serv45 Walker v. Cook, 33 Ill. App. 561. 
ices. $^{46}$ It is to be presumed, however, that attorneys would be much better able to testify as to the facts of usage than the layman, and for that reason it has also been held that laymen are not competent witnesses in such a matter. ${ }^{47}$ Also, it has been held that a defendant, if not an attorney, is incompetent as a witness as to the value of a lawyer's services. ${ }^{48}$ It has also been held that the usage in the ordinary place of business of a consultant, rather than that where services are rendered, should govern; for in the absence of an agreement beforehand the consultant has a right to expect to receive his usual fee. So, "A lawyer residing in another state, where another lawyer resides, is competent to testify as to the value of the legal services rendered by the latter, rather than an attorney living in such latter state." 49

88. Definition and Scope of Expert Testimony. The following rules, taken from "The Law of Expert and Opinion Evidence," by Lawson (1900), give the facts so clearly and concisely that they are here quoted.

"Rule $35 . .^{50}$ An expert is a person having special knowiedge and skill in the particular calling to which the inquiry relates."

"Rule $36 .{ }^{51}$ Therefore, to render the opinion of a witness admissible on the ground that it is the opinion of an expert, the witness must have

46 Hart $\nabla$. Vidal, 6 Cal. 56.

47 MeNiel v. Davidson, 37 Ind. 336.

48 Howell v. Smith, 108 Mich. 350,66 N. W. 218.
49 Stanberry $\nabla$. Dickerson, 35 Iowa 493.

30 p. 229.

51 p. 231. 
special skill in the subject concerning which his opinion is sought to be given."

"Rule 37.52 But the opinion of an expert is inadmissible where the subject is not one of special skill or knowledge, but of general observation or experience, which can be better answered by persons in another calling, or is upon a question which the court or jury can themselves decide on the facts."

"Rule 38.53 The opinion of an expert on a question of law, or ethics, or on matters of mere speculation, is inadmissible."

"Rule 39.54 An expert may be qualified by study without practice, or by practice without study. But mere observation without either is insufficient."

"Rule $43 .{ }^{55}$ The qualification of a witness as an expert is a question for the trial court, whose decision is not generally reviewable on appeal."

Opinions of experts are incompetent unless questions of skill or science are involved. ${ }^{56}$ Before giving expert testimony the standing of the witness as an expert should be presented to the court. The testimony of a veterinary witness must be judged very differently according to whether his standing as an expert comes as a result of years of practice, without previous special education, or from recent study in the laboratory and with books. Sometimes perhaps one, and sometimes perhaps the other should be considered the more competent, according to the point involved. The court and

52 p. 238.

53 p. 242.

${ }^{64} \mathrm{p} .246$.

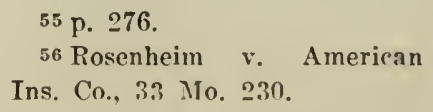


jury must therefore know before hearing his expert opinion how he claims his standing, in order to know how to estimate his statements. No amount of general experience as a veterinarian would qualify a person ignorant of bacteriology to testify as to an animal disease when bacteriologic questions are involved. A loorse may be apparently sound, and yet for years be a carrier of the Bacillus mallei, and thus be the cause of the loss of much stock. A veterinarian ignorant of bacteriology should not be considered competent to testify as an expert in a case brought to recover damages for the spread of glanders from that horse. "A physician, called as an expert, cannot be allowed to testify as to his opinion whether a certain plaster, which he has not examined, was poisonous; his opinion being based upon his experience, study, and facts personally known to him, all of which were not in evidence." 57

Where a physician, testifying with regard to a broken leg, has minutely described the nature of the fracture, he may give his opinion as to the position of the leg at the time of the accident, and the point from which the blow came.58 An expert may give the grounds and reasons of his opinion in his examination in chief, as well as the opinion itself. ${ }^{59}$

When a medical witness, in an action upon a warranty of a horse, had stated that he had read

57 Burns v. Barenfield, 84 Ind. 43.

58 Johnson v. Steam Gauge \& Lantern Co., 146 N. Y. 152, 40 N. E. 773, affirming 72 Hun 535, 25 N. Y. Sup. 639.
59 Lewiston Steam Mill Co. v. Androscoggin Water Power Co., 78 Me. 274, 4 Atl. 555; Keith v. Lothrop, 64 Mass. 453. 
various standard authors on the subject of diseases, and had given his own opinion in respect to the character of the disease of which the horse died, it was proper to ask him for his best medical opinion thereon according to the best authority. ${ }^{60}$ In an action for breach of warranty in the sale of a stallion, where the defect complained of is a spavin, testimony of expert witnesses is admissible to show that the defect is subject to be transmitted in breeding. ${ }^{61}$ ( $\left.\$ 206.\right)$

89. Compensation as Expert. It is quite common for those needing the service of experts in American courts to make special arrangements for the pay for such services. Such a previous understanding is very much the better way, but it is not always made, and therein comes a new complication. In fact, a large proportion of expert witnesses do not know what rights they may have; and in consequence some have been committed to jail for too great insistence upon what they considered their rights. Although some courts, and one state, have affirmed the right of the court to call for the services of an expert witness, whether he wishes to serve or not, it is generally recognized that his services as an expert are at his own disposal, even though there may be some question as to his right to special compensation. In other words, it rests with the witness whether or not he shall become an expert witness in the case before the court.

A physician cannot be compelled to make a post mortem examination, according to a Texas ${ }^{60}$ Pierson v. Hoag, 47 Barb. 243.

61 Fitzgerald v. Erans, 49 Minn. 541, 52 N. W. 143. 
decision; but having made such an examination he becomes a witness of fact, and may be compelled to testify as to the result of the examination made by him. ${ }^{62}$ He made his decision as to testifying when he made the examination.

We have previously said that a witness should be impartial. Too frequently both witness and spectators seem to imagine that an expert, like an attorney, is hired to get one side out of trouble. Theoretically this should not even be true of the lawyer. $\mathrm{He}$ is an officer of the court to secure justice; but since he is opposed by contending counsel, justice can only be secured when each side is presented in its strongest color. This excuse does not avail for biased testimony, whether of fact or of expert opinion. The witness is sworn to tell the truth. A contract with an expert witness for compensation, conditional on the success of the suit in which he is to testify, is void, as against public policy. ${ }^{63}$ It should be sufficient grounds for impeaching the expert's entire testimony, for it throws doubt upon the honesty of his opinion, and raises a suspicion that there may have been imposition upon the court of a plea for a client, disguised as evidence. It is such unlawful abuse of privilege which has tended to bring reproach upon the name of expert testimony in American courts.

An agreement by one to go into court at a future day and testify as an expert in regard to a matter which he had examined as a civil engineer (or as a veterinarian), is sufficient consideration for a 62 Summers v. State, 5 Tex. App. 365.

${ }_{63}$ Pollak v. Gregory, 9 Bosw. 116. 
promise to pay a reasonable compensation in addition to statutory fees. ${ }^{64}$

Where there has been no previous arrangement with regard to compensation for expert testimony, there has been some disagreement among the decisions. In the English courts it is generally agreed that extra compensation may be taxed. ${ }^{6.5}$ In the case of Webb v. Page it was said," "There is a distinction between the case of a man who sees a fact, and is called to prove it in a court of law, and a man who is selected by a party to give his opinion on a matter on which he is peculiarly conversant from the nature of his employment in life. The former is bound, as a matter of public duty, to speak to a fact which happens to have fallen within his own knowledge; without such testimony the cour'se of justice must be stopped. The latter is under no such obligation; there is no such necessity for his evidence, and the party who selects him must pay him." In such opinion many American decisions concur. ${ }^{67}$

On the other hand it has several times been held that the expert is not entitled to extra compensation. ${ }^{68}$ Perhaps strictly there may be no essential disagreement from a legal point of view be-

64 Barrus v. Phaneuf, 166 Mass. 123, 44 N. E. 141.

65 Batley v. Kynoek, L. R. :0 Eq. Cas. 632; In re, Laffitte, L. R. 20 Eq. Cas. 650 .

661 C. \& K. 23.

67 Buehman v. State, 59 Ind. 1, 26 Am. R. 75; Dills v. State, 59 Ind. 15; In re Roelker, I Sprague, 276; U. S. v. Howe, 12 Cent. L. J. 193.
68 Summers $\ulcorner$. State, $\bar{j}$ Tex. App. 365 ; Ex parte, Dement, 53 Ala. 389 ; State v. Teipner, 36 Minn. 535; 32 Minn. 678; Larimer County Commrs. v. Lee, 3 Col. App. 177, 32 Pac. 841; Flinn r. Prairie Co.. 60 Ark. 204, 29 S. W. 459; Dixon $v$ People, 168 Ill. 179. 
tween these apparently conflicting statements. As we remarked above, when a physician, a veterinarian, or other expert, makes an examination to enable him to give expert testimony, as by performing a post mortem examination, he becomes a witness of fact, and as such can be compelled to testify without extra compensation. However, the party requesting a veterinarian to examine and treat his animals is thereby putting himself under obligations to pay a reasonable sum for the services rendered; and the reasonable sum must depend upon the character of the services rendered. On this same basis the man who is asked to make an examination as a preliminary to giving expert testimony has a legal right to expect compensation for his services as an expert. ${ }^{69}$ Though this compensation may not be included in the fees taxed by the court in which the expert evidence has been given, apparently the witness may have therein ground for action against the person engaging his services, where there is no law to the contrary. It seems reasonable, also, that a distinction should be made between cases in which the community needs the services of an expert in criminal prosecutions, and those in which his services are required for the benefit of parties engaged in civil suits.

Several states have enacted statutes providing that witnesses called to testify only on an opinion, founded upon special study or experience, shall receive additional compensation to be fixed by the court. Such statutes are found in Iowa, North

69 Barrus v. Phaneuf, 166

Mass. 123,44 N. E. 141. 
Carolina, Rhode Island, Louisiana, Minnesota, North Dakota, and Wyoming, and they should be found in all the states.

Some years ago in a criminal case in Indiana a physician refused to give his expert opinion until he should be assured of extra compensation. The trial court committed him for contempt. Upon appeal to the supreme court the decision of the lower court was reversed. This carefully considered opinion is, perhaps, the best of our American decisions. In it the court said: ${ }^{70}$

"While a physician or surgeon could be required to attend as a witness to facts without other compensation than that provided by law for other witnesses, yet he could not be required to testify as to his professional opinion without compensation of a professional fee. The professional knowledge of an attorney or physician is to be regarded in the light of property, and his professional services are no more at the mercy of the public, as to remuneration, than the goods of the merchant, or the crops of the farmer, or the wares of the mechanic."

This case excited so much comment in the state that the legislature enacted a statute, which, while it is law, and binding upon the citizens of the state, seems to be unworthy of so great a commonwealth. This statute is as follows: ${ }^{71}$

"A witness who is an expert in any art, science, trade, profession, or mystery may be compelled to appear and testify to an opinion as such expert, in relation to any matter, whenever such an opinion is material evidence relevant to an issue on trial

70 Buchman v. State, 59 Ind. 1, 26 Am. R. 75.

71 528, Burns' Annotated Statutes (1914). 


\section{COMPENSATION}

before a court or jury without payment or tender of compensation other than the per diem and mileage allowed by law to witnesses, under the same rules and regulations by which he can be compelled to appear and testify to his knowledge of facts relevant to the same issue." 



\section{PART III PERTAINING TO GOVERNMENTAL CONTROL}





\section{CHAPTER VI.}

GOVERNMENTAL SERVICES.

$\S$ 95. The Veterinarian as an Officer.

$\S$ 96. Liability of Officers.

$\S$ 97. Officers with Discretion Cannot Be Coerced.

\$ 98. Arbitrary Action Not Discretion.

§ 99. Authority Limited by Jurisdiction.

$\S 100$. Authority Determined by Legislation.

$\$ 101$. Invalid Act Is No Defense for Officer.

$\S 102$. Quarantine.

$\S 103$. Quarantine Does Not Depend upon Statute.

$\S 104$. Authority Cannot Be Delegated.
$\S 105$. What Diseases Quaran. tinable.

$\$ 106$. Methods in Quarantine.

$\S 107$. Quarantine Regulations Should Be Published.

$\S 108$. Diagnosis.

$\S 109$. Jurisdiction in Quarantine.

$\S 110$. Quarantine Versus Commerce.

$\S 111$. Destruction of Property. \$ 112. Personal Liability for Infectious Disease.

$\S 113$. Law Versus Policy.

$\S 114$. Appraisement.

$\S 115$. State and National Officers, at Same Time.

95. The Veterinarian as an Officer. Veterinarians are frequently occupied in governmental positions for the nation, state, or city, and such services are daily becoming more common and more necessary. As a rule, these duties are performed by veterinarians as employees, rather than as officers. For a discussion of the relative rights and duties of officers and employees the reader is referred to Chapter $\mathrm{X}$ of my Public Health. It is necessary that the person entering upon governmental work should have a clear idea of the limits of his authority, as well as a knowledge of the 
liabilities to which he exposes himself. An error of the representative of a city government may possibly involve the city in a liability; for the city is a corporation which may be sued. Exactly the same kind of an error by one employed by the state or nation would not involve the liability of either state or nation, for they are supposed to do no wrong, and therefore they cannot be sued. But if a man occupying the position of an officer or employee of the state or nation does an act which is wrong, in so far he is really a private wrongdoer, just like any other, and his official position does not protect him from suffering the penalty. If any one has been injured by his unlawful act, civil suit may be brought against him. It does not matter that he acted in good faith, that he supposed that he was within his authority, or that he thought his act for the common good. Relying upon the purity of his motives, he finds that good intentions pave the way to-trouble.

It is the duty of a public officer or employee to know what he is doing, and that his act is within his legal power. Intentions don't count. Impressions are misleading. Knowledge is important. This knowledge is not difficult to obtain. It is within easy reach, but the trouble is that too frequently the officer is content with certain general ideas, very loosely comprehended, until he is suddenly brought into court to suffer for his well intentioned misdeeds. Very frequently it is more the manner in which a thing has been done, than the thing itself, which is objectionable.

96. Liability of Officers. Whatever is required of an officer by law should be done, and if he fails 
to perform the act he may be punished. But where there is discretion, the officer may do anything within that discretion. ${ }^{1}$ The fact that an officer is given discretion in the performance of his duties does not imply that he can do as he pleases. It is essential that the act be the ontcome of personal investigation and consideration, and it must be based upon reason. If the act be not the outcome of such examination and consideration, or if it be the expression of individual will, not clearly dependent upon reason, it will be considered as arbitrary. No arbitrary act is authorized in American law. ${ }^{2}$ When an officer is vested with discretionary authority he is personally liable for an abuse of that authority." "It follows that boards of health may not deprive any person of his liberty, unless the deprivation is made to appear, by due inquiry, to be reasonably necessary to the public health." 4 The case of Kirk v. Wyman, just cited, was one in which it was held that the board of health did not have authority to establish such a quarantine as was attempted in a case of anesthetic leprosy, as the disease was very slightly contagious. A board of health ordered the destruction of a glandered horse, but they had to respond in personal damages because the court decided that the evidence presented failed to show that the horse was really suffering with glanders. ${ }^{5}$ In a similar manner a health officer was held personally liable for the destruc-

1 Public Health, 270, 271.

2 Public Health, 273.

3 State v. Yopp, 97 N. C. 477 , 2 S. E. 689.
4 Kirk v. Wyman, 83 S. C. 372,65 S. E. 387.

5 Miller v. Horton, 152 Mass. 540 . 
tion of cattle which were in fact not a nuisance, nor a cause of sickness endangering public health, but were mistakenly adjudged by him so to be. This was not an error in judgment, but it was the result of too slight examination into the facts, and he thereby exceeded his authority. ${ }^{6}$ In another instance a professor in a normal school was a member of a board of health and he found that wood alcohol was contained in the vanilla flavoring in a certain bakery. He published an article in a local paper in which he referred to "The recent finding of wood alcohol in the socalled vanilla used in one of our local bakeries," and after saying that good vanilla costs about $\$ 12.00$ per gallon, wholesale, asked "What can one expect for $\$ 2.75$ ?" He did not mention the name of the baker, though he was easily identified. The professor was found guilty of libel, on the ground that the article was not a plain, official, statement of facts, but that it was evidently inspired by a vindictive spirit. It intimated that the baker bought his vanilla for $\$ 2.75$ per gallon; but the baker showed that he paid $\$ 4.00$ per gallon. ${ }^{7}$

Where the officer of health keeps within his authority neither he, nor the city, nor the state, nor the nation can be held liable in damages to those who may be injured through his act. But when he exceeds his authority he is legally regarded as no longer an officer, and he must personally bear the consequences. "Absence of bad faith can never excuse a trespass, though the

6 Lowe v. Conroy, 120 W'is. 151, 97 N. W. 942.
7 Hubbard v. Allyn, 200 Mass. 166, 86 N. E. 356. 
existence of bad faith may aggravate it. Every one must be sure of his legal right when he invades the possession of another." 8

Because a municipality is not liable for the acts of its representatives in preserving the public health, and because an excess on the part of the official exposes him to personal liability, it has even been held that where the officer has been actuated by worthy motives, and has acted for the common good, as he saw it, if he shall have exceeded his authority, and shall have been assessed damages, he must pay those damages personally, and the municipality may not lawfully reimburse lim. ${ }^{9}$

\section{Officer with Discretion Cannot Be Coerced.} A duty which is coupled with discretion implies the free exercise of judgment. ${ }^{10}$ Such an officer, therefore, cannot lawfully be coerced in making his decision, nor to act contrary to his opinion when formed. The courts cannot force such an officer to take a certain line of action. ${ }^{11}$ If, under the stress of fear, or intimidation, such an officer should adopt a certain line of action he must bear the responsibility of such action. If his act be shown to be without the scope of his authority, or contrary to the provisions of law, he may be held personally liable for injuries resulting from his

8 Cubit v. O'Dett, 51 Mich. 347 (per Cooley, J.).

9 Kempster v. Milwaukee, 79 N. W. 743, 97 Wis. 343; Lawrence v. MeAlvin, 109 Mass. 311 ; Uren v. Walsh, 57 Wis.
98; Robinson r. Rohr, 73 Wis. 436.

10 Public Health, 271, 274.

11 Seymour v. U. S., 2 App.

D. C. 240 . 
act. ${ }^{12}$ A superior officer is not ordinarily liable for the torts of his inferior. ${ }^{13}$

98. Arbitrary Action Not Discretion. Discretion implies the use of reason, not of will. If the act is not based upon a clear use of reason it will be considered as arbitrary, and the officer will be held personally liable for any harm which may result. ${ }^{14}$ This may be very important for official veterinarians to remember. Under a general authority to quarantine animals for an infectious disease, and to kill those which it may be necessary to destroy to restrict an infectious disease from spreading, it would probably be held necessary to show that the animals killed were in fact a danger to the community. ${ }^{15}$ This might excuse the slaughter of animals actually diseased, and those animals exposed to the infection, in which the disease had not as yet been demonstrated. Since many diseases develop in the affected animals an immunity to future attacks, in such animals as had passed through the disease and recovered, it might be presumed that such an immunity had removed the danger. If such animals were ordered killed, as the result of a hysterical fear, rather than from scientific knowledge, the officer so ordering might be held personally liable for the full value of animals thus unnecessarily destroyed.

99. Authority Limited by Jurisdiction. It is very evident that a person, a corporation, or a 366.

12 Public Henlth, 360, 365, 366; State v. Yopp, 97 N. C.

12. Public Henlth, 367.

14 Public Health, 273, 365, 477.

15 Public Health, 201. 
governmental body, cannot grant that which the grantor does not possess. In other words, the officer has no greater range of authority than the body which he represents. Under appropriate legislation, therefore, a city inspector, a state inspector, and an inspector connected with the Bureau of Animal Industry in the national Department of Agriculture would have very different powers in the same case. Suppose that they met upon a dairy farm which sent its products to a neighboring city in the same state. The national representative would have no authority in the matter until the dairyman attempted to send his products out of the state, though he discovered that there was typhoid fever upon the farm, and that insufficient care was taken to prevent contagion. The city inspector would have no direct authority in the case, but he conld suggest certain changes in operation, and in case his suggestions were not accepted and acted upon he could order the exclusion of the products of the farm from his city. This would still leave the farmer at liberty to sell to other communities. The state official would have the authority to order such changes in operation as reason and law dictated, and in the absence of complete obedience he might put a quarantine upon the farm.

In the case above supposed, the city inspector has no anthority because the farm is outside of his juriscliction, though it is necessary for lim to go beyond his territorial jurisdiction to make his inspections. His authoritative jurisdiction is limited to the city boundaries. The authority of the nation is found in its power to regulate inter- 
state and foreign commerce. It has no authority in purely internal affairs in the individual states. The state official has full authority, provided the state has enacted laws which grant him the authority.

The rules of the Bureau of Animal Industry of the Department of Agriculture, organized by Act of Congress, May 29, $1884,{ }^{16}$ known as the "Animal Industry Act," for the suppression of contagious disease among domestic animals, have not, apart from the action of a state, any binding force upon the state. ${ }^{17}$ In the case of a contagious disease in the Chicago Stockyards the Chicago authorities, and the Illinois authorities might enforce a local quarantine. The national representative could not do this, but in case he considered the act necessary he might quarantine the whole state of Illinois. In case that a Chicago inspector found that infected dairy products were being shipped from farms in Wisconsin to Chicago, he would have no legal authority to stop those products until they reached the city limits. The state representative could stop them at the state line. Neither could exert authority within Wisconsin. On the other hand, before the goods left the farm, when they were marked for shipment to Chicago destinations, the national official could step in and seize the goods, for interstate commerce begins as soon as the goods are prepared for shipment. ${ }^{18}$

16 C. 60,23 St. 31. 18 Public Healti, 238.

17 Eshleman v. Union Stockyards Co., 222 Pa. 20, 70 Atl. 899. 
National authority is specified in the Constitution, and so far as concerns veterinarians it is practically limited to the control of interstate and foreign commerce. The authority of the city is only such as has been given it by the state, and the city official has no authority ontside of the city limits. The state has supreme police power over all matters within its boundaries, according to the ordinary interpretation of the Constitution.

100. Authority Determined by Legislation. Except possibly in the case of a very few of the principal officers, the duties and authority of all governmental representatives are determined by enactment. The enactment may be a constitution, a state legislative act, or a city ordinance. In each case the act is found in print or engrossed, and its provisions can be ascertained. The officer or employee should therefore become familiar with the exact wording of all enactments pertaining to his position. An act duly passed will be presumed to be law until it has been declared not valid. But the law may have been so declared, and still be permitted to remain upon the statute books. It therefore becomes necessary to know what judicial determinations there may have been upon the matter.

101. Invalid Act Is No Defense for Officer. Where an officer of state or city has acted in perfect good faith, relying upon a certain statute or ordinance for his authority, and in the course of his efforts he has worked injury to some citizen, either in person or property, if it shall later appear that the statute was unconstitutional, or that 
the city had exceeded its authority in framing the ordinance, so that the enactment is void, the officer cannot plead as justification either the fact that he was complying with the terms of the illegal enactment, or that he was acting in good faith. ${ }^{19}$ It therefore becomes evident that the governmental veterinarian should not be content with mechanically following the statute, or the orders of his superior officer. He should learn at least the principles of law governing the position.

102. Quarantine. An infectious disease is a nuisance, and as such it should be abated. The animals in which it exists are not of themselves nuisances, and they have commercial value in most cases. The disease cannot be summarily abated without also destroying the animals. For this reason we are accustomed to adopt certain restrictive measures. At one time the only method upon which dependence was placed was quarantine. The period of isolation may safely be materially lessened by certain modern methods by which the disease germs, or their carrier's, are destroyed, without injuring the stock.

\section{Quarantine Does Not Depend upon Statute.} Where there is an enactment directing where and how a quarantine shall be established, that enactment must be observed; but where the law is silent, the police power of the community will support any reasonable measure taken for the

19 Publc Health, 361 ; Fisher v. MeGirr, 1 Gray, 1; Ely v. Thompson, 3 A. K. Marsh, 70; Osborn v. Bank, 9 Wheat. 738; Norton v. Shelby Co., 118 U. S. 425 ; U. S. v. Lee, 106 U. S.
196; Cunningham v. Macon $\mathrm{R}$. R. Co., 109 U. S. 446; Poindexter v. Greenhow, 114 U. S. 270; Sumner v. Beeler, 50 Ind. 341; Board v. McComb, 92 U. S. 531. 
restriction of the disease. The validity of quarantine regulations made by the state board of health is a matter for state courts to determine. ${ }^{20}$ Where the statute authorizes a city to take such measures for the restriction of infectious disease as are demanded, according to the opinion of the authorities, the city is not bound by the provisions in the general statutes regulating quarantine, and in one case it was held that they were justified in quarantining both sides of a double house where smallpox was in one side. ${ }^{21}$ But in all cases the regulations must be impartial, and reasonable, and fitted for their purpose. ${ }^{22}$ Though reasonable regulations will be considered as law, the orders or regulations of a health department differ from enacted statutes, in that citizens are not supposed to know them. ${ }^{23}$ In prosecutions for violation of such regulations it is therefore incumbent upon the prosecution to show that the party did have knowledge, or that at least the notice was served before the violation charged.

104. Authority Can Not Be Delegated. Where the law grants the authority to a board to establish and maintain quarantine, the board cannot delegate that authority to a health officer. ${ }^{24}$ The general rule is that authority vested with discretion cannot be delegated. (§9.) The matter of

20 Louisiana r. Texas, $176 \mathrm{U}$. S. 1.

21 Highland r. Schulte, 123 Mich. 360, 82 N. W. 6.).

22 Wilson v. Alabama, G. S. Ry. Co., 77 Miss. 714, 28 So. 567 ; Wong Wai v. Williamson, 103 Fer. 1; Hannibal \& St. I.
R. R. Co. v. Husen, 5 Otto, 465. 23 State v. Butts, 3 S. Dak. 577,19 L. R. A. 725,54 N. W. 603.

24 Taylor v. Adair Co., 119 Ky. 374; Hickman V. MeMorris, $149 \mathrm{Ky} .1,147 \mathrm{~S}$. W. 768. 
deciding when quarantine must be established or removed, and the style of quarantine to be adopted, is one which implies discretion and consideration. This cannot be delegated. But the board or other health authority can employ the services of an officer or private citizen to carry out the methods and acts which the proper health authority directs. It is not to be presumed that the officer or board would personally maintain the quarantine. ${ }^{25}$

105. What Diseases Quarantinable. Any infectious disease, propagated by means of bacteria or protozoa, is subject to quarantine, whenever the welfare of the community demands such action. Quarantine is never justifiable where its maintenance does not restrict the disease. Cholera is an infectious disease due to the action of a specific bacillus, but in the light of the present knowledge a quarantine which simply prohibited the entrance or exit of persons from the premises would not be considered as proper quarantine. Yellow fever is a better illustration. Malaria was not formerly considered subject to quarantine, but with our present knowledge, even in the absence of special laws relative to that disease, a quarantine would be justifiable under certain conditions. It would not be justifiable in a community in which there were no anopheline mosquitoes, for there the quarantine would be useless, and therefore unreasonable. It therefore follows that quarantine is not an invariable method of restricting disease.

25 Breckenridge Co. v. MeDonald, 154 Ky. 721,159 S. W. 549. 
Diseases which were formerly not considered subject to it are today restricted by its use; and it is not unlikely that diseases which are not today recognized as spread by germs may later be stamped out by quarantine.

106. Methods in Quarantine. Formerly quarantine consisted simply in preventing the entrance of persons or animals upon infected premises, or their exit therefrom. Fences were erected around yellow fever premises, but the disease spread. Now effective quarantine is maintained by screening in the patient, and killing the mosquitoes. After three days the yellow fever patient is no longer able to transmit the disease to the stegomyia mosquito, and further quarantine is useless. The malarial patient must be kept under guard sometimes for months. Rats, and the fleas which they carry, are the means by which the bubonic plague is spread. Quarantine in these cases therefore means destruction of the vermin for a certain district, always working from the outside of a circle in whose centre infection has been found. ${ }^{26}$

In veterinary practice a quarantine may mean only the restriction of certain kinds of animals, or the restriction of the passage of all members of the animal kingdom. For the Texas cattle fever quarantine includes killing the ticks, either by dipping the infected animals, or by destroying the animals and disinfecting the premises. Infected animals may be useful for food purposes, so that burning the carcasses is not necessary, as it is for anthrax. Anthrax has been known to be 403.

26 PUblic Health, $\$$ 402, 
spread by the overflowing of pastures by streams which received the discharge of tanneries in which infected hides had been treated. ${ }^{27}$ Reasonable quarantine there might therefore include the prohibition of the use of such pastures. Dourine was formerly supposed to be spread only by intercourse, and under such conditions quarantine would only prevent such relations between the healthy and the sick. The experiments on the Canal Zone, however, showed that the disease may be spread by flies. A reasonable quarantine of many animal diseases must include screening against insects. All that is necessary and efficient will be sustained; nothing in excess of that would be approved by the courts, in most instances; but in deciding what shall, and what shall not, be sustained the courts will be guided not only by past usage, but also by scientific advances when properly presented. It is necessary that the officer presenting some new method for the consideration of the conrt remember that his own bare statement of fact may not be enough; he may be obliged to say how his position in opinion has been gained. It may not be enough to say that yellow fever is only transmitted by the bite of the stegomyia, but the officer should state how that fact has been demonstrated; and the necessity for such presentation is in direct ratio to the newness of the demonstration.

A state statute in Wyoming directed the state veterinarian to quarantine for certain diseases; and it further gave him authority to order infected

27 Ravenel, Rept. Am. Pub. Health Assn., 1898, p. 302 ; Rus-

sell, Rept. Wis. Agr. Expt. Station, 1900, p. 171. 
animals sprayed or dipped, and after reasonable notice, on the failure of the owner to obey, the veterinarian might seize and dip the animals, and hold them, or sell them for the cost of the procedure. The constitutionality of the law was attacked. The court held that the only authority of the state for the enforcement of animal inspection laws was as a police regulation. The authority conferred by the legislature upon the state veterinarian was not an improper delegation of legislative power, nor a violation of due process of law, though the reasonableness of the requirements imposed by the state veterinarian might be litigated were they properly put in issue. ${ }^{28}$

107. Quarantine Regulations Should Be Published. Quarantine rules and regulations may be general or specific. In the specific application of general rules to individual cases it is often necessary to make special orders. These orders, including the general laws and regulations on the subject, should be served in writing, or printed, upon the responsible party caring for the animals to be quarantined; and a record should be made of the facts by whom and on whom the papers were served, and the time when. If the orders be written a carbon copy should be preserved by the officer. This may avoid complications in the future, and furnishes the basis of proof in case of legal contest. General rules and regulations, whether issued by a board or by an executive officer, should be published in such a manner as to be easily accessible to all citizens, and especially

28 Arbuckle v. Pflaeging, 123

Pac. 918, 20 Wy. 351. 


\section{ESSENTIALS OF VETERINARY LAW}

to attract the attention of those most interested. If enacted by a board, the minutes of the board should show a quorum present, and that the rules or regulations were formally presented and passed, and they should be fully recorded in the minutes. The record should also show either that the meeting was a regular meeting, or that it was legally called. Violations of these provisions might be held to be a violation of due process of law, in that the rictim had no opportunity to be heard. ${ }^{29}$

108. Diagnosis. The matter of diagnosis in infectious diseases is most important. Clearly such a decision should only be made by those who are technically educated, and who are free from special interest. In other words so nearly as possible it should be made with reference to animal disease only by a veterinarian, and that veterinarian should be a public officer who is not engaged in private practice. It should never be subject to review in court, where the judge must depend upon others for exper' opinion. On the other hand, especially where the local work is in charge of veterinarians engaged in private practice, justice demands that either side may appeal within the department. This implies that there be a thoroughly organized department, either within, or without, the regular state department of health. This provision should be made clear in the general statutes of the state. It is the province of the official veterinarian to make the diagnosis, even where the statute is silent upon this point, and he will be upheld generally by the courts,

29 People v. Tait, 261 Ill. 197, 103 N. E. 750. 
wherever there is any ground for his decision..$^{30}$ Nevertheless, cases have occurred in which courts have seen fit to review and reverse the decision of health authorities relative to infectious diseases in animals. ${ }^{31}$

Inasmuch as infectious diseases are the result of the action of specific germs, either bacterial or protozoal, where those germs have been definitely identified by microscopic examination, the sure method of diagnosis is by such examination. It has therefore been held that a city has, under its general powers, the authority to appoint a bacteriologist; and that such office or employment is not an interference with the work of the regular health official, but an aid in this work. ${ }^{32}$ While, then, a court may not generally interfere with the diagnosis of an official veterinarian, it might very properly set aside a diagnosis which was evidently not made in accord with the present state of scientific knowledge. The cause of glanders is the Bacillus mallei, which is well known. It is not unlikely that where a veterinarian has neglected to verify his diagnosis by means of a bacterial examination or blood test the court might properly question his diagnosis. If, therefore, the veterinarian orders a horse killed for that disease he should make and preserve microscopic slides showing the Bacillus mallei taken from that

30 Kennedy v. Board of Health, 2 Pa. 366; Brown v. Purdy, 8 N. Y. 143; In re Kaiahua, 19 Ha. 218: Thomas v. Ingham Co. Supervisors, 142 Mich. 319 ; Browne v. Livingston Co., 126 Mich. 276; Jew
Ho v. Williamson, 103 Fed. 10. 31 Miller v. Horton, 152 Mass. 540 ; Lowe v. Conroy, 120 Wis. 151, 97 N. W. 942.

32 State ex rel. Sholl v. Dunean, 162 Ala. 196, 50 So. 265. 
horse, and each slide should be so marked as to be proper evidence to present in trial of possible future action in the case. In such cases the court would not be reviewing the diagnosis, but it might set the diagnosis asicle as a violation of discretion, in that the veterinarian had not made use of approved methods of diagnosis. ${ }^{33}$

109. Jurisdiction in Quarantine. Questions as to jurisdiction in quarantine occasionally arise. ${ }^{34}$ First it must be remembered that the authority of Congress, and consequently of federal officers and employees, is found in the power to regulate interstate and foreign commerce. "Disease, pestilence, and pauperism are not subjects of commerce, although among its attendant evils. They are not things to be regulated and trafficked in, but to be prevented, as far as human foresight or human means can guard against them." ${ }^{35}$ Therefore "Congress has not only the right to pass laws regulating legitimate commerce among the states and with foreign nations, but also it has full power to bar from the channels of such commerce illicit and harmful articles." 36 The federal government thus has power under the commerce clause to maintain such inspection and quarantine as may be necessary to prevent the introduction of infectious diseases or their germs from foreign countries, or into one state from another. Ordinarily the individual states may do nothing which would interfere with the federal control over interstate

33 Public Health, 407.

34 Public Health, 408.

35 License Cases, Thurlow v. Mass; Fleteher v. Rhode Island;
Peirce v. New Hampshire, 5 How. 504.

$36 \mathrm{McDermott} v$. Wisconsin, 228 U. S. 115. 
traffic, and the authority of the nation begins with the shipment of the goods, and only ends when the goods are sold, or mixed with the property of the state. $^{37} \mathrm{~A}$ shipment from one point in a state to another point in the same state, but where the goods pass through a point in another state, is interstate commerce. ${ }^{38}$ "Although, from the nature and subject of the power to regulate commerce, it must be exercised by the national government exclusively, this has not been held to be so where in relation to the subject matter different rules might be suitable in different localities. At the same time, Congress could by affirmative act displace the local laws, and substitute laws of its own, and thus correct any unjustifiable and oppressive exercise of power by state legislation." ${ }_{39}$ While, therefore, even in such cases Congress still has power to act, in matters pertaining to localized conditions and dangers Congress has elected to let the several states regulate the matter of protecting the public health as to themselves seemed best. ${ }^{40}$ Because disease is not a fit subject of commerce, state officers have maintained quarantine at their borders, although the subjects of the quarantine had already been passed by federal officers of health, and the federal courts have denied their own right to interfere by an injunction; and the costs and charges of such quarantine inspection under state laws may be lawfully im-

37 Brown v. Maryland, 12 Wheat. 419.

38 Hanley v. Kansas City S. Ry. Co., 187 U. S. 617 ; State v. St. P., M. \& O. Railroad Co., 40 Minn. 267; Sternberger v. Cape
Fear \& Y. V. R. R., 29 S. C. 510.

39 Louisiana v. Texas, $176 \mathrm{U}$. S. 1.

40 Bartlett v. Lockwood, 160 U. S. 357 . 
posed upon the carrier which brings the persons or animals into the state, as being incident to the business in which it is engaged. ${ }^{41}$ The authority of the individual states to enact such laws is beyond question, even where their operation interferes with interstate or foreign commerce, but this authority cannot be made to cover discriminations and arbitrary enactments. ${ }^{42}$

Primarily the authority of quarantine, being derived from police power, resides in the state; and cities, villages, towns, counties or other districts have only such power as has been given to them by the state in which they are located. Thus, under the power given by the state a county in Kentucky might establish and maintain quarantine against other parts of the same state, but it could not establish a quarantine against another state, nor against any part thereof, unless that power be distinctly given by the act of the state legislature. ${ }^{43}$ "Cities are no longer enclosed by stone walls and separate and apart from the balance of the state. The sanitary condition existing in any one city of the state is of vast importance to all the people of the state, for if one city is permitted to maintain insanitary conditions that will breed contagious and infections diseases, its business and social relation with all other parts of the state will necessarily expose other citizens

11 Minn., St. Paul \& S. S. M. Ry. Co. v. Milner, 57 Fed. 276.

42 Simpson v. Shepard, (U. S.) 33 Sup. Ct. 729 ; Hannibal, etc., R. Co. v. Husen, 5 Otto, 465; Hurst v. Warner, 102
Mich. 238; Salzenstein v. Mavis, 91 Ill. 391 ; C. \& A. R. R. Co. v. Erickson, 91 Ill. 613; Jarvis v. Riggin, 94 Ill. 164.

43 Allison v. Cash, $143 \mathrm{Ky}$. 679,137 S. W. 245. 
to the same diseases." 44 The state does not surrender quarantine authority to its component parts by such permissions, and its power and authority to establish quarantine within its limits is not today questioned. ${ }^{45}$ A statute delegating to a city the power to make quarantine regulations is not unconstitutional, ${ }^{46}$ but "A municipality has no implied power to establish quarantine regulations, and is not liable for the compensation of an officer employed to enforce quarantine regulations against a neighboring town in which an epidemic occurs." 47 In such a case the officer employing such guardian, having exceeded his lawful authority, and being the officer of an incorporated city, may be possibly held individually liable for his pay. Even where authority has been delegated by the state to a city or county to establish and maintain quarantine, its ordinance will be declared void if it conflicts with state quarantine laws. ${ }^{48}$

110. Quarantine Versus Commerce. Properly considered, quarantine is an aid to commerce, and not a restriction of commerce. ${ }^{49}$ By preventing the transportation of infectious materials commerce in legitimate articles is facilitated and made more safe. But laws passed under the guise of quarantine regulations, which are not such in fact, but are really commercial restrictions, will not be sustained. ${ }^{50}$ The Idaho sheep law of 1897 made it

44 State Board of Health v. Greenville, 86 Ohio, 1.

45 State ex rel. Adams v. Burdge, 95 Wis. 390,70 N. W. 347, 37 L. R. A. 157.

46 Metcalf v. St. Louis, 11 Mo. 102.
47 New Decatur v. Berry, 90 Ala. 432.

48 People v. Roff, 3 Park. Crim. Cas. 216.

49 Public Health, 409.

50 Hannibal, etc., R. Co. v. Husen, 5 Otto, 465; Salzenstein 
unlawful to bring sheep into the state without having them dipped. This was to prevent the introduction of certain infectious diseases, but as the statute was worded the dipping had no necessary connection with the presence of disease. All sheep must be dipped, and the dipping of sheep which were not infected would increase the cost of the importation. By thus increasing the cost of importation, the value of the sheep already within the state would be increased. This law was therefore considered as not strictly a quarantine regulation, but as a restriction upon interstate and foreign commerce, and therefore as an infringement upon the Constitutional authority of Congress. ${ }^{51}$ On the other hand, where the act clearly related to quarantine, as where it put restrictions upon cattle coming from infected districts, ${ }^{52}$ or where it required an inspection of sheep before permitting them upon the public highways, ${ }^{53}$ it was upheld. The Idaho law of 1899 provided for the establishment of a sheep quarantine upon proclamation of the Governor. Acting under this law the Governor issued a proclamation for the quarantine of sheep on account of scab. The court, however, held that this was really a restriction of commerce, because in fact there was no disease epidemic. ${ }^{54}$

It is evident that the establishment and maintenance of quarantine may restrict the commer-

v. Mavis, 91 Ill. 391 ; Jarvis v. Riggin, 94 Ill. 164.

51 State v. Duckworth, 5 Ida. 642, 51 Pac. 456.

52 Smith v. St. L. \& S. W. R. Co., 181 U. S. 248.
53 Rasmussen v. State of Idaho, 181 U. S. 198.

54 Smith v. Lowe, 121 Fed. 753. 
cial relations of those thus restrained; and that this restriction may work financial injury to certain persons. A health official, acting within his legal authority, is not liable for such injuries resulting from reasonable and customary measures as he may, in good faith, adopt or order for that purpose with regard to persons or matters within his jurisdiction. ${ }^{55}$ But if it shall be shown that his act has been unreasonable, and not in accord with scientific knowledge, or that he otherwise has exceeded his authority, he may be held in civil damages for such injury as may appear. ${ }^{56}$

111. Destruction of Property. Property destroyed under police power requires no compensation according to the common law. ${ }^{57}$ ( $\left.\$ \S 15-22\right)$ In this it differs from the taking of property under the power of eminent domain. In eminent domain the property is taken for the use of the public. Under police power the property is taken and destroyed because it is harmful, and "the property itself is the cause of the public detriment." "58 But it is necessary that the property destroyed be in fact a nuisance, and ex parte condemnations of property are not conclusive. ${ }^{59}$

112. Personal Liability for Infectious Disease. The owner of a flock of sheep infected with scab

55 Allison v. Cash, $143 \mathrm{Ky}$. 679; 21 Cyc. 405; Seavey v. Preble, 64 Mo. 120; Whidden v. Cheever, 69 N. H. 142, 44 Atl. 908; Beeks v. Dickinson Co., 131 Iowa, 244.

56 Lowe v. Conroy, 120 Wis. 151, 97 N. W. 942.

57 Freund, Police Power, 517.
58 Davidson v. New Orleans, 96 U. S. 97.

59 Salem v. Eastern R. Co., 98 Mass. 431; Shipman v. State Live Stock Commrs, 115 Mich. 488; Lowe v. Conroy, 120 Wis. 151; Waye v. Thompson, $15 \mathrm{~L}$. R. Q. B. D. 342; Miller v. Horton, 152 Mass. 540. 
which broke through a fence which it was his duty to maintain, and infected a neighbor's sheep, was held liable for damages. ${ }^{60}$ In another case the owner of the infecting sheep pleaded "the act of God" in that his sheep escaped during a severe storm, and also that the owners of the other flock permitted his sheep to mingle with their own. The court nevertheless held the owner of the first flock liable because it was not shown that the storm was of such an unusual character that he could not reasonably liave anticipated it, and guarded against it; and it further held that the owners of the second flock were not guilty of contributory negligence, because the fact that the first flock were infected was not at first apparent. ${ }^{61}$ If the circumstances create a suspicion that a dog may have hydrophobia, the owner must use special care to prevent his spreading the infection, and if injury results through his negligence he will be held liable. ${ }^{62}$

The keeping of an animal having an infections disease is not per se culpable, and it will not give a right of action for damages sustained in consequence of the disease being communicated to other animals unless the owner of the diseased animal knew that it was diseased, and was guilty of some negligence in the manner of keeping it. In an action against a stockyards company for death of cattle from Texas cattle fever, alleged to have been communicated to them by ticks which

60 Herrick v. Gary, 65 Ill. 101. 61 Mesa De Mayo Land and Live Stock Co. v. Hoyt, 24 Colo. App. 279, 133 Pac. 471. 
had dropped in pens of the stockyards company, the plaintiff is bound to show that the cattle alleged to have dropped the ticks were in the pens, and that they contaminated the same, and that the company did not disinfect the pens. It will be presumed that the stockyards company did its duty in the absence of evidence to the contrary. A purchaser who bought cattle subsequent to infection, has no right of action for the negligence to which the disease is due, in the absence of evidence that the company knew, at the time of sale, that the cattle were infected. ${ }^{63}$

A plaintiff rented a barn to defendant company, in which to house horses injured or temporarily incapacitated while performing certain work. The fact that defendant innocently housed a glandered horse in the barn, resulting in its destruction by the public authorities, did not constitute a trespass, and the defendant was not liable for the value of the barn. ${ }^{64} \quad(\S 211$.

113. Law Versus Policy. Although, as we have stated, property which is taken and destroyed for the public good under police power differs from that taken under the power of eminent domain in that its confiscation imposes no legal obligation for payment, this is an extreme use of the power. "Where it is proposed to exercise such an authority the constitutional right of private property must be weighed against the demands of the public welfare, and it is obvious that a public interest

63 Eshleman v. Union Stockyards Co. $222 \mathrm{~Pa}$. 20, 70 Atl. 899.

64 Farrar v. Andrew Peterson
\& Co., 72 Wash. 482, 130 Pac. 753, 44 L. R. A. (N. S.) 1092. Affirmed on rehearing, 72 Wash. 482, 133 Pac. 594. 
which is strong enough to justify regulation may not be strong enough to justify destruction or confiscation without compensation." 65 The destruction of sound property without compensation would be unconstitutional. ${ }^{66}$ Dead animals and garbage may have a property value, yet the rights of property of the individual have been held subordinate to the general good, and the confiscation and destruction of such property without compensation to the individual owner has been repeatedly upheld..$^{6 \pi}$ Milk which has not been produced in accordance with the requirements of a city still has commercial value. Nevertheless, when an attempt has been made to bring such milk into the city it has been repeatedly held that the city is justified in seizing the milk and destroying it. ${ }^{68}$

Animals afflicted with infectious diseases are nuisances. The disease germ is a nuisance per se and as such the community demands its extermination. Unfortunately it is so intimately associated with the animal which has a property value that its extermination may involve the destruction of the animal, as in the case of anthrax, according to our present knowledge. The animal infected with the disease is a nuisance in esse, and as such is subject to such reasonable restriction

65 Freund, Police Power, 517.

66 Pearson v. Zehr, 138 Ill. 4S; Miller v. Horton, 152 Mass. 540 .

67 California Red. Co. v. Sanitary Red. Works, 199 U. S. 306; Gardner v. Mich., 199 U. S. 325; McGehee, Due Process of Law, 236; Public Health, 450 .
68 Blazier v. Miller, $10 \mathrm{Hun}$, 435; Deems v. Mayor, 80 Md. 164; Shivers v. Newton, $45 \mathrm{~N}$. J. L. 469 ; Nelson v. Minneapolis, 112 Minn. 16; Adams v Milwaukee, 144 Wis. 371, 129 N. W. 518; Adlams v. Milwaukee, 228 U. S. 572. 
as seems to be required for the general good. The animal infected with anthrax has no property valne, no matter how very valuable it might have been previous to infection, for the dangerons germ is so intimately associated with the tissues as to render them dangerous even after they have been cured by various processes, such as in the tanning of hides. Since there is no property value there is no moral, as well as no legal, obligation on the part of the community to pay for such animals when destroyed.

An animal infected with tuberculosis may be considered in a very different light. Here, too, the bacillus is a nuisance per se, and the animal is a nuisance in esse. However, the animal may have still considerable value. Her milk may be sterilized and used for food for other animals; or it may be used in certain manufacturing enterprises. If killed, not infrequently the entire carcass can be used for ordinary purposes, with very slight exceptions. The animal may be very valuable for breeding purposes, begetting healthy stock of a strain showing many generations of careful selection in breeding. The destruction of this animal may be a serious detriment to the animal industry. Since the disease cannot be separated from the animal, according to present knowledge, and it will eventually prove fatal, and its presence creates a constant danger to other animals, including man, the right of the state to take the animal and destroy it should not be legally doubted. On the other hand, the taking of such animals without compensation begets a feeling of injustice in the minds of the property owners thus 
harmed, and incites them to keep the existence of the disease secret so long as possible. Policy therefore dictates that the community share with the owner his loss, by paying to him a portion of the value of the animal.

When the disease is one from which the majority of the patients will recover, while there can be no question as to the right of the community to institute a strict quarantine, there may be considerable doubt as to its right to destroy the stock without compensation, and this compensation may be much closer to the original value of the stock. Although the keeping of an animal afflicted with an infectious disease is not per se culpable, still under police power the owner might be compelled to bear the expense of such reasonable quarantine as might be ordered. Under police power we sometimes require high licenses, to help pay for the supervision of the business, and we require owners of dairies to go to the expense of erecting sanitary barns, and milkhouses equipped with expensive machinery. On the other hand, if the owner of the diseased animal shall be so negligent as to permit the spread of the disease to the stock of others he will be held liable for the injury thus sustained. ( $\S 112,211$.$) Through the negligence$ of one man an entire community may be seriously damaged. Under police power the community may demand that the man who insists upon keeping his diseased animals must insure the community against possible damage. It would therefore seem that the community would have a perfect right, by means of proper legislative action, to require that the owner of stock which was 
afflicted with an infectious disease must file an indemnity bond, of appropriate amount, with certain public officers for the benefit of the community. In addition, where the amount of supervision will be considerable, and where the care required will be unusual, as compared with temporary infections, the community should insist upon the owner of the stock paying for the necessary expense of quarantine. Rather than do these things, many owners of stock will willingly surrender their stock for destruction, on receiving a portion of their value. This method would destroy the less valuable stock, would provide for the preservation of the valuable animals under legitimate conditions, and would furnish the most favorable conditions under which to make further studies which might lead to the conquering of the malady.

114. Appraisement. Where the statutes provide for the payment of money for animals destroyed, they also specify under what conditions such appraisement shall be made, and by whom. Unfortunately, too often appraisements are the merest guesses, or they represent a form of graft. Because they offer themselves so readily for graft they are highly objectionable, and such settlement should be avoided if possible. It would be far better if the statute providing for compensation should provide a flat rate for animals of the same species and disease, in lieu of which the owner might execute bonds as suggested in the previous section. Thus, for a cow afflicted with anthrax no compensation should be given, while for one suffering from tuberculosis the community might 
agree to pay fifty dollars in a section where the ordinary price for such an animal in health would be from $\$ 75.00$ to $\$ 100.00$ or mole. The flat rate would afford less opportunity for graft.

There can be no property right in a nuisance per se. Where the nuisance disease has become so closely associated with the tissues of an animal as to be practically inseparable, and where, in consequence, the animal has become a danger to the community, the animal itself may be also considered a nuisance per se. When, therefore, the animal becomes infected with anthrax the owner has thereby lost his property right in the animal. If he has no property right, there can be no legal excuse for paying him for his beast. There would be more justice in requiring him to bear the expense of the destruction of the animal, for so long as the animal lives it will be a source of expense, and will expose the owner to liability for damages through spread of the disease. ( $\$ 1112,211$.

In a disease like that of cattle affecting the feet and mouth, conditions are very different. An appraisement of such a herd will involve several items. Starting with the original value of the stock before becoming infected, the appraiser should deduct the following items:

(1) Value of proportion which would probably die.

(2) Cost of care of herd until free from disease (plus possible earnings).

(3) Depreciation in value of stock after the disease.

(4) Possibly, the cost of quarantine supervision.

(5) In some cases, the amount which the owner may recover from the carcasses. 
115. State and National Officers, at Same Time. Because of the conflict of jurisdiction in matters pertaining to health, between state and national officers, and the consequent complication which may arise; and also sometimes in order to gain the advantage of the experience of those of wide observation, it is sometimes arranged to make national officers deputy state officials (or less frequently, perhaps, to give a state officer the position of a deputy of the federal official). In such cases it must be remembered that in maintaining a quarantine within a state, or in enforcing local measures for the stamping out of a disease, the officer is really working as a state officer. It would seem proper, therefore, that all legal actions begun by or prosecuted against an officer so working should be in state courts. Owing to the presence of plague in New Orleans an ordinance was passed requiring the rat-proofing of the entire city. Assistant Surgeon General Rucker of the U. S. Public Health Service, a man with a wide experience in this line of work, took charge of the work of extermination. Action was brought against him by certain citizens, alleging that he was overzealous, arbitrary and unreasonable in his enforcement of the rat-proofing ordinance; and an injunction was asked to restrain his activity. The U. S. District Court, before whom the matter was brought, claimed jurisdiction on the ground that he was a federal officer. With due humility we are forced to differ with the learned court, although it is a duty of federal officers, according to the Statutes of the United States, to assist in the enforcement of state quarantine 
measures. The ordinance was enacted under the authority of the state, and it is almost universal practice to recognize in such matters the authority of the state courts. ${ }^{69}$ Though in this matter the act was being enforced by one who held office under the national government, strictly we do not believe that in this he should be regarded as such. The court did not issue the injunction asked, ${ }^{70}$ and the Louisiana supreme court later passed upon the validity of the ordinance. ${ }^{71}$ If the federal court did not have jurisdiction over the substance of the ordinance it was apparently incompetent to pass upon the enforcement of the same.

By the Act of March 3, 1905,72 "'The Secretary of Agriculture is authorized and directed to quarantine any state or territory or the District of Columbia, and any portion of any state or territory or the District of Columbia, when he shall determine the facts that cattle or other live stock in such state or territory or District of Columbia are affected with any contagious, infections or communicable disease." But the expression "any portion of any state," etc., does not give authority to establish a quarantine within a state, but against a portion of a state. This is apparent from sections 2, 3 and 4 of this act, wherein it is specially mentioned that shipment from the quarantined portions of states into other states and territories is prohibited. The power of Congress

69 Public Health, 139.

70 Mrs. Wid. John G. Kuhlman et als. v. Rucker, Mch. 15, 1915, 30 U. S. Public Health Reports, 1033.
71 City of New Orleans $v$. Sanford, 69 So. 35.

7233 Stat. 1264. 
is over interstate commerce, not intrastate, and when it is practicable to quarantine against a portion of a state, rather than against an entire state, the Secretary of Agriculture has that authority. The federal local inspector, in so far as he is enforcing interstate quarantine is a federal officer; but his federal authority does not cover services in maintaining intrastate quarantine. Since his authority does not cover such work, neither should he be considered as under the protection of the federal courts in matters outside of his authority, unless, possibly, there be an attempt on the part of the state government to personally restrain him from the performance of his real official duties. 


\section{CHAPTER VII.}

\section{GOVERNMENTAL INSPECTION.}

$\$ 120$. Work of Veterinarians.

$\S 121$. Methods of Governmental Control.

DAIRY BUSINESS

$\S 122$. Quality of Goods.

$\S 123$. Dairy Inspection.

$\S 124$. Confiseation.

$\S 125$. Veterinary Authority in Milk Industry.

§126. Dairy Products.

\section{MEAT INDUSTRY}

$\S 127$. Transportation of Live Stock.

$\S 128$. Departmental Veterinarians.

§199. General Quarantine Regulations.

$\S 130$. Texas Cattle Ferer.

$\S 131$. Protection of Inspectors.

$\$ 132$. Liability of the Department.

$\S 133$. Seabies.

$\S 134$. Hog Cholera and Swine Plague.

$\S 135$. Dourine.

$\$ 136$. Lip and Leg Ulceration (Necrobacilliosis).

\$ 137. Glanders.

$\S 138$. Tubereulosis.
$\S 139$. Foot and Mouth Disease.

\$140. Imported Animals.

$\S 141$. Importations from North America.

$\S 142$. Federal Supervision at Slaughterhouses.

$\S 143$. Antemortem Examination.

$\S 144$. Postmortem Examination.

$\$ 145$. Condemnations.

$\$ 146$. Sterilization.

$\S 147$. Disobeying Orders.

\$ 148. Arbitrariness.

$\S 149$. Appeal.

$\S 150$. Prosecutions.

$\S 151$. Statutes.

$\S 15$. Meat Inspection.

$\S 153$. Intrastate Meat Industries.

\$ 154. Municipal Control.

$\S 155$. State Regulation.

\$156. Common Law Regulation.

\section{BIOLOGIC SUPERVISION}

\$157. Biologic Products.

§ 158. Governmental Responsibility.

\$ 159. Evidence of Infection. 
120. Work of Veterinarians. In various phases of the governmental work of the city, state and nation the services of veterinarians are required for inspection service. In the supervision of dairies and their products veterinarians are needed to assure the healthfulness of the cattle, or goats, and as a portion of their duty they must be depended upon to give tuberculin tests whenever required. In the matter of meat production veterinarians are required to make inspections before and after slaughtering, to detect diseases among animals, and to exclude such meats as may show conditions which would endanger human life were they consumed. In the dairy industries the veterinarians are thus used by cities, states and the national government. In the meat industry their most important service is under the federal laws, and to a less extensive, but not less important degree, they may be employed in some cities and states. Veterinarians also find occupation in the detection and restriction of animal diseases. Their services are also required by the national government in the supervision of the manufacture of biologic products.

121. Methods of Governmental Control. There are three methods possible in governmental control over industries which concern the people generally. First, governmental ownership, which while especially applicable in such a matter as water supply, and though it has been recommended or suggested for milk supply, ${ }^{1}$ would

1 Jethro Brown, Underlying Principles of Modern Legislation, p. 202. 
not at present seem to be ordinarily either advisable or acceptable for American cities. Under this method the municipality would own and operate its own dairy business. It is true that to a limited extent municipalities have tried to manage the sale of milk, but so far as the writer is aware they have not attempted to own and operate milk farms. On the other hand, public slaughterhouses have been maintained, but generally as purely commercial concerns, and not for health supervision.

The second method, much in vogue among English governments both in the British Isles, and in the colonies, is through the use of the courts, making dealers liable for any injuries sustained by their patrons. According to this system civil actions in damages are brought against offenders by those injured, without statutory enactment, and under the usages of the common law. ( $\S 13$.) This efficient aid in sanitation has been too much neglected in the United States. A dairyman, or dealer in animal foods, frequently runs the risk of such harm as may result from his lack of care. He may ignore statutes, in the hope that he will not be caught, or with a calculation of the relative financial adrantage of paying occasional fines, rather than to bear the cost of expensive equipment and operation. He may ignore the orders of a health department, and when prosecuted he not seldom sets up the cry that he is being persecuted, rather than prosecuted, and he thereby gains the sympathy of the jury. If fined, he still may be able to convince his customers that it was for some technical and non-essential point. But 
when action is brought against him for typhoid fever, or for scarlet fever which has been communicated through the agency of the milk, the sympathy of the jury is against the dairyman, and the moral effect in the community of an adverse decision is strong. A fine imposed through a prosecution of the health department has little deterrent effect; but damages assessed for harm done by infected milk is injurious to his business. A single damage suit, therefore, will have a powerful deterrent effect, to prevent his future lack of care; and it will influence all the dairymen of the vicinity more than much inspection and many prosecutions. This method, besides being more effective, has the advantage that it is less expensive for the government, and it does not require the enactment of special ordinances, or the issuance of special regulations. While one weakness of ordinances lies in the fact that adjacent cities or villages may adopt different, and even conflicting, regulations, the weakness of this method consists in the fact that it must wait for its operation until harm has actually occurred, and this injury must often result in much sickness and many deaths in the community before the proof is sufficiently strong to warrant action. This method, therefore, must be used chiefly as supplemental to the third method.

The third method, and the one universally adopted in America, consists in governmental supervision. Statutes and ordinances are enacted, generally requiring the issuance of licenses, and specifying under what conditions the business may be conducted. These licenses are issued 
under police power, and they include governmental inspection to see that the rules and regulations are being properly observed. The weakness of this method consists in the expense of supervision, and the consequent opportunity for frequent evasions of the rules when the inspector is not present. Much depends upon the natural, as well as educational, qualifications of the inspector to detect vital defects, rather than unimportant violations.

\section{DAIRY BUSINESS.}

122. Quality of Goods. Both the national and state governments, as well as cities under permission from the state legislatures, have frequently enacted statutes fixing certain standards of purity for articles of food. While such regulations pertain more to the work of food inspectors, rather than to that of veterinarians, they may also be of incidental interest to veterinarians. A statute fixing 12 per cent of butter fat for ice cream was upheld in Iowa; the court permitting the sale of an article containing a smaller amount, but not as ice cream. ${ }^{2}$ A city may, under the general welfare clause, by ordinance regulate the conduct of the milk business, but it cannot arbitrarily prescribe that ice cream containing less than a certain percentage of butter fat shall not be sold at all. ${ }^{3}$ Neither has a city the right, or an implied power, to license milk dealers where the state has attempted to regulate the business, and has re-

2 State v. Hutchinson Ice Cream Co., 147 N. W. 195.
3 Rigbers v. City of Atlanta, 7 Ga. App. 411, 66 S. E. 991. 
quired a license of all dealers. ${ }^{4}$ A dealer may be required to know the quality of goods which he sells. $^{5}$ A Minnesota ordinance prohibiting the sale of cream with a less percentage of butter fat than 20 was upheld, ${ }^{6}$ and one in the city of Washington which required three and one-half per cent of butter fat was pronounced reasonable, although it did presume an unusual care in the selection and feed of the cattle. ${ }^{7}$ The selection of the cattle must include inspection to insure the healthfulness of the animals, and such care in breeding that in obtaining the good points evil tendencies may not be intensified. In each of these fields the veterinarians have occupation as the employees of the farmers. Intelligent breeding requires careful technical training such as farmers seldom have had. Many other provisions relative to the composition of the product have been attempted, generally with approval.s

123. Dairy Inspection. It is generally agreed that the governments have the right to regulate the milk and dairy business, and to require licenses for which fees are charged. ${ }^{9}$ A board has, or may be given, power to withhold license for insanitary conditions. ${ }^{10}$ When a city has the power to regulate the business by issuing licenses,

4 Bear v. City of Cedar Rapids, 147 Iowa, 341,126 N. W. 324,27 L. R. A. (N. S.) 1150.

5 Dist. of Columbia v. Lynham, 16 App. D. C. 85; Commonwealth $\nabla$. Wheeler, 205 Mass. 384, 91 N. E. 415.

6 State $\nabla$. Crescent Creamery Co., 83 Minn. 284, 54 L. R. A. 466 .
7 Weigand v. Dist. of Columbia, 22 App. D. C. 559.

8 PUBlic Health, 466-469.

9 State ex rel. Niles v. Smith, 62 Fla. 93, 57 So. 426.

10 State ex rel. Niles v. Smith, 62 Fla. 93, 57 So. 426. 
it has also the power to revoke a license, without notice, and summarily. ${ }^{11}$ The city of Asherille, $\mathrm{N}$. C., passed an ordinance requiring milk dealers to take out licenses, for which they. were to pay one dollar per cow. One Nettles refused to take out the license on the grounds that his herd was outside the limits of the city; that the fee was excessive; and that he sold only to one customer, a creamery. But the necessity for inspection of the dairy is not less because the herd is outside of the city, and the expense thereof may be greater. It is not presumed that the cattle will be held in the city. It is not sufficient safeguard to depend only on examinations of the milk itself. Dangerous infections might thus be overlooked. The only way in which the municipality can protect its citizens is by requiring license issued under certain restrictions, and accompanied by an inspection of the business from start to finish. Neither is the fact that the milk was sold directly only to one customer a reason for laxity in supervision, especially when that one customer is a creamery. The ordinance was upheld. ${ }^{12}$ Where the dairy is within the territorial jurisdiction of the municipality certain methods may be used which are inapplicable in extraterritorial jurisdictions. The city is therefore forced to depend upon its commercial jurisdiction in the latter case, and enforce it through licenses in the form of a modified contract. The dairyman agrees to do certain things, in return for which the city gives him a right to sell his product within the eity. In the

11 State v. Milwaukee, $121 \mathrm{~N}$. W. 658,140 Wis. 38 .
12 Asheville v. Nettles, 164 N. C. 315,80 S. E. 236 . 
city he could be punished in the police court should he refuse to do the reasonable things specified by ordinances. It therefore happens that we may find in the ordinances relating to such occupations as the milk business a distinction made between dairies within and without the city. An ordinance recognizing the difference between dairies outside and inside the municipal jurisdic tion, and requiring a difference in the management of the two, is therefore reasonable. ${ }^{13}$ But "Necessary restriction cannot sanction or cover arbitrary discrimination." 14 When a health department is convinced that the conditions under which the milk is produced make it unsafe for consumption it is the duty of the department to stop the sale of the product within its limits. ${ }^{15}$ This does not mean that harm will necessarily result from the use of such milk, but that harm is likely to follow. In this Bellows case the court said: "It is unreasonable to say that the department of health, in exercising such power, renders itself amenable to the charge of exercising extraterritorial jurisdiction. In notifying the creamery company not to include the plaintiff's milk in its shipments to the city, it was acting for the protection of the inhabitants of the city of $\mathrm{New}$ York, and therefore for local interests. There was no interference with the plaintiff's conduct of his farm or business, except as he proposed to supply milk to the city of New York; there was simply an embargo laid on the introduction, within the

13 Adams v. Milwaukee, 144 Wis. 371,129 N. W. 518 ; also, 228 U. S. 572.
14 Freund, Police Power, 640. 15 Bellows v. Raynor, $207 \mathrm{~N}$. Y. 389, 101 N. E. 181. 
city of New York, of milk not produced by him under conditions specified by the department. It had the right to exact from all shippers of milk a compliance with such conditions as would reasonably tend to a pure product for the use of the citizens as a condition for permitting its sale in the city of New York."

An ordinance forbidding the feeding of cattle on distillery slops, and prohibiting the sale of the milk of cattle so fed was upheld as a proper use of police power. ${ }^{16}$

Modern sociologic and commercial conditions have very materially changed the relationship of the milk industry to public health. Formerly the milk was delivered to the customer within a few hours at the most after milking; the cows were generally within easy inspection by the customer; and an infected pail of milk conld endanger few persons. Now the milk for our large cities must be transported from large areas, often outside of the state in which it is consumed. The customer does not even know, as a rule, from what state his supply comes. A pail of milk which is infected at the milking may infect several carloads at a bottling plant, and the time between milking and delivery is such that there may be a great multiplication of a few bacteria. A strict supervision of the industry is therefore an urgent governmental responsibility.

It is now generally recognized that bovine tuberculosis may be the cause of much of the disease in the human being, though this was formerly

\footnotetext{
16 Johnson v. Simonton, 43

Cal. 242.
} 
disputed. It therefore becomes necessary to thoroughly examine the cattle, not only for tuberculosis, but for other debilitating, or infecting diseases. A cow well advanced in tuberculosis betrays her condition on inspection without special tests, but in the earlier stages the most careful physical examination may fail to discover the infection. In these early cases science demands that the tuberculin test be made, and that it be repeated from time to time. Since this necessity is recognized in science as a most reliable, though not infallible test, ordinances and legal regulations requiring that the test be made are generally upheld. ${ }^{17}$ It is a question for the legislative (or sometimes executive) branch of the government to decide whether or not this test shall be required, and it is not for the court to declare an ordinance unconstitutional or void because some other method, such as pasteurization may appear better. ${ }^{18}$ The early detection of infected animals is really for the interest of the farmers, as well as the consumers of the milk, but Illinois farmers had been purchasing infected cattle from other states to such a degree that they opposed the enforcement of such a rule by the city of Chicago, and under the leadership of Shurtleff secured the passage of a statute in Illinois forbidding cities from making such a requirement. ${ }^{19}$ The legislature had an unquestioned authority to enact such

17 Borden v. Board of Health, Montelair, 81 N. J. L. 218, 80 Atl. 30 ; Adams v. Milwaukee, 144 Wis. 371, 129 N. W. 518; sustained, 228 U. S. 572; Nelson v. Minneapolis, 112 Minn.
16; Hawkins v. Hoye (Miss.), 66 So. 741.

18 Nelson $\nabla$. Minneapolis, 11: Minn. 16.

19 Session Laws, Illinois, 1911, p. 6 . 
a statute inimical to the public weal, and its prohibition was binding upon the state. The legislature which passed it, the leader who engineered it and the governor who failed to veto it, are conjointly entitled to the discredit of the enactment.

Since such requirements as the making of the tuberculin test depend for their trustworthiness upon the careful technique of the operation, to remove as much as possible the danger of unprofessional carelessness or dishonesty of unregulated practitioners, such ordinances or statutes should require that the test be made only by official veterinarians.

Since milk infections are generally bacterial, condemnations of milk are frequently made, and sustained in court, because of the large number of bacteria contained, though none may be proven dangerous to health. The presence of such abnormally large numbers indicates a lack of care in the handling of the product. To guard against infection, and to assist in tracing responsibility, various regulations have been sustained, such as, requiring users to wash the milk bottles, prohibiting the use of milk containers for other purposes, or the having in possession by milkmen of bottles which had not been washed. ${ }^{20}$ The Massachusetts court refused sanction to an ordinance which prohibited the sale of "open" milk, ${ }^{21}$ but the necessity for such prohibition is now so generally recognized that it would probably be sustained. The city of Covington prohibited the sale of less

20 People v. Frudenberg, 140 N. Y. Supp. 17; Polinsky v. People, 73 N. Y. 65.
21 Commonwealth v. Drew, 208 Mass. 493. 
than one gallon in any but transparent receptacles, and the ordinance was sustained. ${ }^{22}$ The Chicago ordinance requiring the name of the dealer to be blown or stamped on the bottle was upheld. ${ }^{23}$

While condemnation of milk on account of bacterial evidence generally depends upon a large content, this is not always so. The presence of the colon bacillus is of itself conclusive evidence of fecal infection, and its presence is therefore sufficient for condemnation. ${ }^{24}$ In a like manner, exposure to a liability of infection with the germs of such diseases as typhoid or scarlet fever, or of diphtheria, or the finding of tubercle bacilli in the milk should be held as sufficient warrant for the prohibition of sale from that source until danger had passed.

124. Confiscation. Milk is not an article which may be impounded and preserved without unnecessary expense. The fact that it has been offered for sale, or that an attempt to ship it contrary to law has been made, is sufficient justification for its confiscation and destruction. ${ }^{25}$ To simply refuse such milk admission to the city would leave the violator free to attempt another

22 Covington v. Kollman, 156 Ky. 351, 160 S. W. 1052.

23 Chicago v. Bowman Dairy Co.. 234 Ill. 294. The Ohio statute providing for the seizure and confiscation of bottles bearing a distinctive name, blown or marked in them, when found in the possession of others was declared unconstitutional, because more extensive than title implied. State v. Schmuck, 77 Ohio, 438, 83 N. E. 797.
24 Dade r. United States, 40 App. D. C. 94.

25 Adams v. Milwaukee, 144 Wis. 371,129 N. W. 518 ; sustained, 228 U. S. 572; Nelson v. Minneapolis, 112 Minn. 16; Blazier v. Miller, $10 \mathrm{Hun}, 435$; Deems v. Mayor, 80 Md. 164; Shivers v. Newton. 45 N. J. L. 469. 
evasion of the law, and get his product into consumption in some other place or way.

125. Veterinary Authority in Milk Industry. A veterinarian's governmental authority cannot extend beyond the limits of the authority of the body under whom he has been appointed. (\$99.) The foregoing outline shows that the authority of a veterinarian in the conduct of the milk business is very slight and inconspicuous, as compared with that of other inspectors. As a city employee he has no authority outside of the city by which he has been appointed, and in the dairy district he acts in an advisory capacity. Of course his advice as to the condition of a dairy may cause the city to refuse the product of the dairy. A state veterinarian has authority within his own state, and his advice may enable the state officers to exclude milk from certain outside territory. The veterinarian employed by the federal government has no authority except with regard to products intended for interstate or foreign shipment.

126. Dairy Products. It is now known that the germs of tuberculosis and typhoid fever may remain viable for a time in butter and cheese. The aging of cheese before sale tends to lessen the langer in that article from those bacteria, but it is liable to another infection with a highly poisonous germ-tyrotoxicon. These dairy products are frequent and extensive subjects of interstate commerce, and to a smaller degree they enter foreign commerce. It is practically impossible to efficiently supervise the commerce without attention to the manufacture. It is entirely within the authority of Congress to enact reasonable statutes 
which would safeguard the manufacture and interstate or foreign sale of the products. Because this trade is so largely within the province of Congress, in order to harmonize methods, and to increase efficiency, Congressional action is preferable to the leaving of the regulation to individual states. A state whose product is largely shipped out of its limits is not likely to put efficient restrictions upon the business.

\section{THE MEAT INDUSTRY.}

\section{Transportation of Live Stock. Congress} having authority over interstate and foreign commerce has placed the supervision of the transportation of live stock under the supervision of the Department of Agriculture, under which the Bureau of Animal Industry takes immediate charge and supervision. Having charge of interstate commerce means also that it has supervision over the means used for transportation, and this includes the railways and steamboat lines, including cars used in the business and the pens in which the animals are collected for shipment, or are unloaded, either for feeding or for sale. A single cow, infected with the Texas cattle ticks, thomgh only intended for shipment within the state, must be under the general supervision of this bureau, for she may infect pens and cars used in the interstate business; and to permit this one animal to be transported within a state without inspection would endanger the wider traffic. Much harm might be done before the possibility of danger would be realized. Incidentally, therefore, the con- 
trol over the interstate traffic includes also an authority over the strictly intrastate transportation.

128. Departmental Veterinarians. Inspectors are appointed by the department after a civil service examination, to which are admitted only the graduates of veterinary schools of approved standing, having courses of at least three years before a degree is conferred. These inspectors supervise the shipment and inspection of the cattle, and their final slaughter for interstate and foreign commerce, and make the necessary post mortem examination.

129. General Quarantine Regulations. Under the acts of 1884, 1903 and 1905, whenever the Secretary of Agriculture shall determine that the live stock of any section are infected with a contagious or infectious disease, it becomes his duty to declare a quarantine, either upon the entire state, or upon such portion as may seem advisable. In so far as the state quarantine area seems sufficiently protective it is the custom of the Department to adopt the same. The transportation or driving of quarantined animals from the quarantine area, or the permitting them to drift, is strictly prohibited, except under regulations approved by the department. All pens, or means of conveyance, which have been used by infected animals, or by those exposed to infection, must be thoroughly disinfected by approved methods before they are used for other animals. This includes also feeding pens, stockyards, chutes and alleys used by infected or exposed animals. When deemed necessary, the interstate shipments of live stock will be stopped 
for inspection and disposition, and all persons having the animals in charge must submit to the inspection of the stock. Whenever in order to prevent the spread of a disease it becomes necessary to slaughter any diseased or exposed stock the United States is authorized by law to purchase such live stock, and the compensation is either by private agreement with the owner, or by an appraisement in the manner provided by the law of the state in which the owner has his legal residence. In practice it is customary for the state and the nation to share in this compensation. Inspections are made by inspector's of the Department, in the Bureau of Animal Industry, and such inspection and certification as may be required will be performed without the payment of inspection fees. Shipments from a quarantined area, not accompanied with a certificate of an inspector showing freedom from disease or exposure thereto, are not permitted to be diverted for feeding, stocking, or breeding purposes, unless first inspected and certified by an inspector of the bureau. Certificates of inspection and treatment must accompany the stock to the destination, and they then become the property of the transportation company and must be filed for reference.

No dead animal may be shipped, or offered for shipment, interstate, in the same car with live animals from the original point of shipment in any state, territory, or the District of Columbia.

130. Texas Cattle Fever. The quarantine against certain areas for the splenic, or Texas cattle, fever is in force throughout the year. Interstate shipments of cattle from the quarantined 
area may be made at any time by boat or rail for immediate slaughter, provided that the permission has first been obtained from the proper official of the state (or District of Columbia), at the place of destination, under certain strict regulations. They must not be handled over platforms, chutes or alleys used for horses, mules or asses, nor for cattle from noninfected areas. The construction of the alleys, chutes, pens, etc., is strictly regulated to prevent any possible contact with other animals, and the pens must be plainly marked with signs, "QUARANTINED YARDS," or "QUARANTINED PENS." Any cattle driven into these specially reserved pens must be treated as if exposed. Cars or boats used in the transportation of such animals must be conspicuously marked. Cattle from noninfected areas, needing to be unloaded for feed and water, within the infected territory, can only be so handled in specially reserved pens, properly labeled "NONINFECTIOUS PENS," and kept free from possible infection. Cattle from noninfectious areas, infested with the tick, Margaropus annulatus, must be regarded as infected cattle, and subject to the regulations therefor. Cattle from infected areas, or other cattle infected with the ticks, after having been properly dipped twice, at intervals of from 5 to 12 days, by the approved method, may be certified as free from infection with splenic fever, and may be moved interstate for any purpose. If dipped once they may be shipped as "dipped ticky cattle," and if examined and found free in a market centre provided with proper dipping facilities, and there dipped by an inspector within from 5 to 12 days 
from previous treatment, they may be shipped interstate for any purpose, under regulations. Cattle located in areas where tick eradication is being conducted by the bureau in coöperation with the state authorities, and which are on premises known by the inspectors to be free from ticks, may, upon inspection and certification at a suitable season be moved interstate for any purpose, without dipping, provided that they can be moved to the transportation line, or free area without exposure to infection.

Horses, mules or asses which are infested with the ticks must receive the same treatment as is provided for the cattle.

Before accepting a shipment of cattle from a quarantined area to an unquarantined point in another state, the transportation company must obtain from the shipper a signed statement showing the purpose for which the cattle are shipped.

The dipping of cattle by a railroad company transporting them, under quarantine regulations prescribed by law, is so intimately connected with the matter of transportation, that the charges may be fixed at a reasonable sum to be paid by the shippers; and the matter of fixing the charges may properly be made by the Corporation Commission, in Oklahoma. ${ }^{26}$

Cattle must not be transported, driven, nor allowed to drift, from a quarantined area to another portion of the same state outside of the quarantined area. This important rule of the

${ }^{20}$ Midland Valley R. R. Co. v. State, 35 Okla. 672, 130 Pac. 803. 
Department the nation has no legal authority to directly enforce; but what it cannot do directly it may do indirectly. If a single county be quarantined in a state, and the state supervision and enforcement of regulations is so lax that a cow is permitted to go outside of the quarantined area, it becomes the duty of the Secretary to so extend the area under federal quarantine that danger would be eliminated. In the place of a single county he might quarantine the whole state.

131. Protection of Inspectors. A shipment of cattle from the far southrest was about to be made. The cattlemen were impatient to be relieved of their responsibility, and to have a good time. The inspection was almost finished when the comparatively young tenderfoot, called officially an inspector, found one of the ticks. He ordered the entire bunch held for dipping. The result may be imagined, though fortunately no serious harm resulted. The inspector held firm. Realizing the necessity for special precautions Congress inserted the following paragraph into the act of 1905.

"Sec. 5. That every person who forcibly assaults, resists, opposes, prevents, impedes, or interferes with any officer or employee of the Bureau of Animal Industry of the United States Department of Agriculture in the execution of his duties, or on account of the execution of his duties, shall be fined not less than one hundred dollars nor more than one thousand dollars, or be imprisoned not less than one month or more than one year, or by both the fine and imprisonment; and every person who discharges any deadly weapon at any officer 
or employee of the Bureau of Animal Industry of the United States Department of Agriculture, or uses any dangerous or deadly weapon in resisting him in the execution of his duties, with intent to commit a bodily injury upon him, or to deter or prevent him from discharging his duties, or on account of the performance of his duties, shall, upon conviction, be imprisoned at hard labor for a term not more than five years, or fined not to exceed one thousand dollars." (The words "or both fine and imprisonment" should have been added to this paragraph.)

In this connection it is necessary to remember that there may be two or more distinct criminal acts involved in a single physical deed. The section of law quoted above related not to a resistance offered to, nor to an assault upon, a man, but upon an officer or employee of the bureau; and with relation to his work under the authority of that bureau. For this the offender would be tried before a United States Court; but he would also be subject to trial under the laws, and before the courts of the state in which the act was committed for his opposition to, or attack upon the man. His influence in state politics might sometimes give an intending obstructor a degree of confidence, but the strength of the nation may not be lightly put aside.

132. Liability of the Department. The Department of Agriculture does not assume any liability as to loss of stock in treatment. It is the duty of shippers to see that their animals are free from infections disease before they are offered for shipment. Shippers of animals infected with disease 
subject to quarantine expose themselves to prosecution for violations of laws, and to actions in damages for such injury as may be shown. The dipping of animals, or other treatment to remove danger of the spread of infection, when done under the supervision of the bureau, is a strictly governmental action, and for general protection. The State (and that term means nation as well as state), cannot be sued in tort ( $\$ 96)$, and any injury suffered, or loss sustained by a citizen through such governmental operations must be borne without recourse.

133. Scabies. The regulations relative to scabies in cattle or sheep are practically the same as for splenic fever, though the disinfectants used in the dip are different.

134. Hog Cholera and Swine Plague. No swine which are afflicted with hog cholera or swine plague may be lawfully transported, trailed, drifted, or driven from one state to another. Diseased swine in the stockyards must be condemned and slaughtered. Exposed healthy swine may be shipped to a slaughtering centre for immediate slaughter, in cars properly marked. Swine intended for other purposes than immediate slaughter may be shipped from stockyards, subject to the requirements of the state of destination, after being examined and found free from contagious or infectious disease, and after treatment by approved methods by competent veterinarians.

135. Dourine. Horses, jacks, and mules intended for interstate shipment must be examined by an inspector and found free from dourine. Horses and jacks are mentioned in the B. A. I. Order 210, effective July 1, 1914; but the fact hav- 
ing been demonstrated by the work of the hygienic laboratory of the Canal Zone that the disease is transmitted by flies in many instances, and that mules are also liable to the infection, mules also must be included in the inspection, at least during the summer months. Where there has been a possible exposure to infection within eighteen months all interstate shipments are prohibited. Diseased animals are generally condemned and killed. The Department of Agriculture coöperates with state governments, and assumes one half of the appraised valuation of the animal condemned, provided, that the diagnosis has been made by approved laboratory methods; that the owner agrees, and signs a receipt in full; and that the Department's portion of the valuation does not exceed one hundred dollars. In view of the curative and preventive results produced in the work of the hygienic laboratory of the Canal Zone, it is not impossible, should the results be proven reliable, that the killing of such animals may be discontinued.

136. Lip and Leg Ulceration (Necrobacilliosis). Animals showing the disease in more than one tissue, or with pus formation, may not be moved interstate; but mild or inactive cases, treated by veterinarians of the Department, may be so moved.

137. Glanders. Horses, mules, or asses, showing glanders by physical examination or by the mallein test, may not be moved interstate.

138. Tuberculosis. Cattle or swine afflicted with tuberculosis, as disclosed by physical examination or by the tuberculin test, may not be moved interstate. Cattle may not be moved from an area 
quarantined for tuberculosis, except for immediate slaughter, unless found free from the disease by the tuberculin test, and accompanied by their tuberculin test chart. Cattle originating in premises which have been cleaned of tuberculosis under the supervision of an inspector of the bureau, or a coöperating state inspector may be moved interstate for any purpose (subject to a re-examination should the premises later show infection). Cattle within the quarantined area, not visibly diseased or known to be so affected, and which are intended for feeding or grazing purposes, may, on permit issued by an inspector of the bureau, be shipped interstate, subject to such restrictions as may be imposed by the state of destination. Cattle from areas quarantined for tuberculosis which are not visibly diseased, may be shipped interstate for immediate slaughter in car's so marked.

139. Foot and Mouth Disease. For various reasons, the regulations used for the restriction of the foot and mouth disease are less permanent in character than those for the other infectious diseases. The nature of the germ, and its manner of communication, are less definitely known. In consequence the regulations must of necessity show an element of experimental uncertainty. Infected animals cannot be shipped. Other animals when shipped must bear with them certificates or affidavits of owners showing that they have been in the district from which shipped for sixty days before shipment, and that they have not recently been in a public stock yard. The quarantined area is divided, by the last orders issued, into four sub-areas. (1) Closed area; into which cattle, 
sheep and other ruminants, and swine can only be shipped for immediate slaughter; and from which interstate and foreign movement of such animals is prohibited; and the movements of dressed carcasses of such animals, the hides, skins, wool, horns, or hoofs of such animals, or of hay, straw, similar fodder, manure, litter, or bags or similar containers which have been used for stock feed is restricted.

(2) Exposed area: Into which cattle, and other ruminants, and swine, may be moved for any purpose; and from which those animals may be moved for immediate slaughter after examination certification; and from which the movements of dressed carcasses, hides, etc., and fodder is restricted.

(3) Modified area: From which interstate movement of ruminants and swine is permitted for immediate slaughter, without previous inspection, to points in the quarantined area; into which such animals may be moved for any purpose; and from which movements of dressed carcasses, hides, fodder, etc., is permitted without restriction other than usual.

(4) Restricted area: From which cattle and other ruminants and swine are permitted to move for immediate slaughter to points in free or closed areas; or for any purpose to any point in the quarantined area other than closed sections; and into which animals may be moved for any purpose whatever; and from which dressed carcasses, etc., may be moved without other than ordinary restrictions.

A free area is one outside of the quarantined districts. 
140. Imported Animals. With the approval of the Secretary of the Treasury, certain ports are named by the Secretary of Agriculture for the reception of animals imported from other lands. There are certain general regulations as to their reception. Horses, imported from points outside North America, must be accompanied with certificates from competent veterinarians stating that the horses have been examined and found free from dourine or other infectious diseases; and affidavits must be made slowing that they have not recently been exposed to infectious disease. They must then be examined by an inspector of the Bureau of Animal Industry. Infected animals may be excluded or quarantined. No hay or other forage, or straw, accompanying horses from the continent of Europe may be landed until it has been disinfected as the inspector may prescribe. All horses imported, aside from points in North America, are subject to quarantine.

Ruminants and swine must be accompanied by affidavits showing that the animals have been continuously in the district from which shipped for the preceding six months, and that no infectious disease exists there among such animals. This does not apply to animals from North America. Cattle, or other ruminants, or swine from continental Europe must be shipped from certain designated points.

Cattle imported from any point except from North America, Great Britain, Ireland, and the Chamnel Islands, are subject to a quarantine of not less than 90 days from date of clearance of ship. Sheep and other ruminants and swine are 
subject to a quarantine of not less than 15 days; and the period of quarantine for cattle from Great Britain, Ireland and the Channel Islands must be not less than 30 days; but cattle and sheep intended for immediate slaughter may be landed, under certain restrictions, without quarantine. All cattle six months old or over, imported from Great Britain, Ireland, and the Channel Islands, and which are subject to quarantine, must be tested with tuberculin by an inspector of the bureau, either before shipment, or after arrival at the quarantine station. Other cattle are tested in this country.

A person desiring to import ruminants or swine from any point outside of North America must obtain two permits, stating the number, and the kind of animals to be imported; one giving the date and the port of shipment, for the consul at that port; and the other stating the port, and probable date of arrival. After three weeks from dates set, the permits are void.

Dogs, except those classed as house dogs, may be quarantined by the inspector for two weeks to determine the presence or absence of tapeworms. If found infected they must remain in quarantine under treatment.

141. Importations from North America. Animals admitted in bond for shipment in export are subject to inspection at point of entry. Animals for immediate slaughter must be consigned to some recognized slaughtering centre, and must be slaughtered within two weeks from date of entry. Animals imported from Canada must either be accompanied by satisfactory evidence of freedom 
from infectious disease, or quarantined under the supervision of an inspector of the bureau; but horses driven or ridden in for a period of not more than three days, or when returning after an absence in Canada of not more than three days, are not subject to such restrictions. Horses belonging to Indian tribes, settlers and immigrants, or in connection with stock raising or mining, and those intended for temporary stay not to exceed two weeks, may be admitted without inspection upon written permission of the Secretary of Agriculture; otherwise they must be inspected at point of entry.

The importation of tick infested horses from Mexico is generally prohibited until after satisfactory treatment. All ruminants, swine or horses imported from Mexico must be free from infectious disease, but tick infested cattle may be shipped for immediate slaughter to points in Texas. Unless accompanied by satisfactory evidence of freedom from exposure to infectious disease the animals will be quarantined.

\section{Federal Supervision at Slaughterhouses.} The federal control over interstate and foreign transportation of animals is exclusive, and incidentally this practically includes intrastate movements as well. In supervision of the slanghtering industry the federal supervision is distinct from that which should be used over the intrastate industry. Here also the supervision is "under the care of the Bureau of Animal Industry; but in many states the local business is practically free from supervision, and animals condemned by bureau inspectors may sometimes, and those which 
have been withheld from federal inspection because of suspicious indications generally do, gain access to the local trade in such free states. The following paragraphs relate only to the supervision by the bureau.

143. Antemortem Examination. Upon the presentation of satisfactory evidence with an application for the admission of the products of a slaughtering establishment into the interstate and foreign commerce, an inspector from the bureau is assigned to take supervision of the establishment, with needed assistants. All animals designated for slaughter must be first inspected antemortem. Those found diseased are condemned, so marked, and tanked without the removal of the tag. "Suspects" may be retained for further examination, or disposed of according to circumstances. But suspects must be slaughtered at the establishment where inspected, unless released for pregnancy, or similar temporary disability. Neither suspects nor condemned animals are to be slaughtered with those which have passed examination. So far as possible where hogs have been condemned as suspects, other hogs of the same lot must be slaughtered separately from those passed antemortem. Animals showing suspicious symptoms of rabies, tetanus, milk fever, or railroad sickness, or presented for antemortem examination in a dying condition, must be marked "condemned," and so disposed of.

144. Postmortem Examination. All carcasses are carefully inspected, postmortem, for evidence of disease; and for this purpose all parts of a slaughtered animal must be kept together, and 
easily identified, until the condition is finally determined. Condemned carcasses, or condemned parts must be disposed of according to the rulings of the inspector. The inspector must be satisfied that all carcasses or parts accepted are safe, and that parts condemned are so disposed of that they will do no harm.

145. Condemnations. Parts of carcasses held for examination are marked "retained," and all diseased parts must be removed before tilat tag is removed. Carcasses or parts may sometimes be held for sterilization, and so marked. Carcasses condemned are so marked, removed to a locked room, and there kept until disposed of.

Every part of the body of an animal suffering from anthrax must be burned, and the killing bed thoroughly disinfected.

Tuberculosis. The entire body must be condemned if at the antemortem examination it was suffering with fever, cachexia, anaemia, or emaciation; also if the tuberculous lesions are found generalized, or in the muscles, intermuscular tissue, bones or joints; or if there are extensive lesions in one or more of the body cavities; or where the lesions are multiple or acute. Parts must be condemned when they contain tuberculous lesions, or when adjacent to tuberculous lesions, or when contaminated by coming in contact with the floor or a knife soiled with tuberculous lesions. An organ must be condemned when the corresponding lymph glands show infection. But carcasses may be passed when the lesions are slight, localized, calcified or encapsulated, or when they are limited, and with no evidence of recent invasion of the 
bacilli into the systemic circulation. Carcasses revealing lesions more severe or more numerous may be rendered into lard or tallow if the distribution is such that the tuberculous lesions can be removed.

Hog cholera or swine plague. Carcasses of hogs marked as suspicious in antemortem examination must be carefully examined post mortem, and if found afflicted with acute hog cholera or with swine plague they must be condemned. But if the carcass shows no indications of either of these diseases except in the kidneys or lymph glands it may be passed for food. If it shows lesions shight in extent in other organs it may be passed for sterilization.

Actinomycosis. Carcasses showing general actinomycosis must be condemned. Those well nourished, and showing uncomplicated localized actinomycosis may be passed after removal of diseased parts. Heads so affected must be condemned except perhaps in cases where the lesion is slight, and strictly localized.

General Diseases. Carcasses must be condemned for the following diseases or conditions:

Blackleg, Hemorraghic septicemia, Pyemia, Septicemia, Texas fever, Malignant epizoötic catarrh, Unhealed vaccine lesions, Parasitic icterohematuria in sheep, Generalized melanosis, Psendoleukemia, and the like; Acute inflammation of the lungs, pleura, pericardium, peritoneum, or meninges; Septicemia or pyemia, whether puerperal, traumatic, or without evident cause; Gangrenous or severe hemorrhagic enteritis, or gastritis; Diffuse metritis or mammitis; Polyarthritis; 
Phlebitis of the umbilical veins; Traumatic pericarditis; Any acute inflammation, abscess or suppurating sore, if associated with acute nephritis, fatty and degenerated liver, swollen and soft spleen, marked pulmonary hyperemia, general swelling of lymph glands, or diffuse redness of the skin.

Carcinoma. An organ affected with carcinoma or sarcoma must be condemned, but the carcass may be passed unless the disease affects any internal organ to a marked extent, or affects the muscles, skeleton or body lympl glands, or the body shows secondary changes in the muscles.

Localized conditions. All slight, well limited abrasions on the tongue and inner surface of the lips (without lymphatic involvement), suppurating sores, abscesses, bruised tissue, or parts affected by a tumor, must be removed, and in the absence of other indication the carcass may be passed.

Necrobacilliosis. Localized lesions may be removed and the carcass passed, unless there is evidence of a generalized infection, when the carcass must be condemned.

Caseous lymphadenitis. Where the lesions are distinctly local, and superficial, or confined to a few nodules in an organ the carcass may be passed after removal of diseased parts; but where the disease is more extensive the entire carcass must be condemned.

Icterus. Carcasses showing icterus must be generally condemned; but where there is no parenchymatous degeneration of organs, such parts as lose their coloration on chilling may be preserved, 
providing that no part shall be kept for food or sterilization unless the final inspection has been made by natural light.

Carcasses giving off the odor of urine or a sexual odor must be condemned. If the final decision is made after chilling the disposal must be made by the heating test.

Mange or scab. Carcasses showing advanced mange or scab, or with emaciation, or extension of inflammation are condemned. Slight lesions may be removed and the carcass passed.

Carcasses of hogs, otherwise fit for food, may be passed after excising parts affected with urticaria, Tinea tonsurans, Demodex folliculorum, or erythema.

Tapeworm. Carcasses of cattle infested with Cysticercus bovis must be condemned if the infestation is general, or if the meat is watery or discolored. Carcasses showing slight infestation may be passed after removing infested parts. Carcasses showing moderate infestation may be passed for sterilization. Fats of animals passed, or passed for sterilization, may be passed for food provided that they are heated to a temperature of not less than $140^{\circ} \mathrm{F}$. Inspection for Cysticercus bovis may be omitted in case of calves less than six weeks old.

Carcasses of hogs affected with tapeworm cysts (Cysticercus cellulosae) may be passed for sterilization unless the infestation be excessive, when they must be condemned.

Parasites Not Affecting Man. Where animals are affected by parasites which do not affect man, the entire body may be nevertheless condemned if 
the infection be found general. If localized to one organ or part of the body the edible portions of the remainder may be passed after the removal of infected portions. Where limited to a small portion of an edible part of the body the remainder of that organ may be passed.

Carcasses of sheep infested with the Cysticercus ovis after removal of condemned portions must be held for final inspection, and if the total number of cysts found embedded in, or in close relation with, muscle exceeds five the entire carcass must be condemned.

Carcasses of animals showing the presence of gid bladder worms may be passed after removal of the affected brain and spinal cord.

Organs or parts of carcasses infested with Lydatid cysts (Echinococcus) must be condemned.

Livers infected with flukes must be condemned.

Pregnancy. Carcasses in advanced stages of pregnancy, or which have given birth within ten days, may be passed for sterilization, provided there is no evidence of septic infection. In that case the entire body must be condemned.

Degeneration. Animals too emaciated for food, or which show slimy degeneration of fat, or serous infiltration of muscles must be condemned.

Too young. All stillborn or unborn animals, and those too immature to make good meat must be condemned.

IJogs which have entered the scalding vat alive, or which have been suffocated in any way, must be condemned.

Chicken feed. Meat and organs condemned on account of parasitic infection, the flesh of imma- 
ture or emaciated animals, and those condemned on account of parturition may be utilized for the manufacture of chicken feed, after being thoroughly sterilized by an approved process, in official establishments for that purpose, removed from those used for food products for human beings.

146. Sterilization. Every portion of the work of the slaughterhouse must be under the supervision of the inspectors of the bureau. This includes such side work as rendering, preserving and canning. In each instance the Department specifies how the process is to be performed.

147. Disobeying Orders. As previously stated, the supervision of the government in this industry is in the nature of a contract. Should the owner of the slaughterhouse break this contract by disobeying orders it would terminate his right to ship his products, either directly or indirectly, through the interstate or foreign commerce. While he may not be subject to a fine or other punishment, nor liable to an action in tort, this threatened loss of trade acts as a potent force for the maintenance of discipline.

148. Arbitrariness. It must not be presumed that the inspector has arbitrary authority. According to the American system of government no officer of civil government is permitted to exercise arbitrary authority or power $(\S 8)$. All actions of the inspector must be based upon enacted statutes, and with a reasonable interpretation. The statutes are made applicable through Departmental regulations. The final decision is made through the operation of executive decision. 
149. Appeal. The courts have no appellate power over matters properly within the jurisdiction of the inspectors. ${ }^{27}$ If it be a question whether the inspector has authority over certain matters, this is a question of law for the courts to decide. If objection be made because the inspector has been mistaken in his judgment, the courts have no jurisdiction. On the other hand, appeal is possible within the department. It must be remembered that the govermment and the manufacturer are working together, and that the manufacturer reaps the benefit.

150. Prosecutions. It is seldom necessary to prosecute offenders against the orders of inspectors, as such. Prosecutions are generally based upon violation of the statutes regulating interstate commerce, and as such are brought before federal courts.

151. Statutes. The foregoing regulations are made under the authority of and for the carrying out of the provisions of the following federal statutes.

Animal Inspection and Quarantine. ${ }^{28}$ The Act of May 29, 1884, provides for the establishment of the Bureau of Animal Industry in the Department of Agriculture; for the investigation of animal diseases; for the facilitating of animal industry through restriction of infectious diseases, and inspection of cattle for shipment interstate, or foreign.

The Act of Feb. 3, 1903, ${ }^{29}$ increases the authority of the Bureau by transferring certain powers

27 Public HeAlti, 141. 2932 Stat. 791.

2823 Stat. 31. 
formerly conferred upon the Secretary of the Treasury to the Secretary of Agriculture.

The Act of March 3, 1905, ${ }^{30}$ enables the Secretary of Agriculture to establish quarantine districts for different diseases, and to regulate the movements of animals therefrom, and more fully to control the spread of infectious diseases of animals.

The Acts of June 29, 1906, ${ }^{31}$ and of March 4, $1913,{ }^{312}$ are for the prevention of cruelty to animals during shipment, and for the regulation of transportation.

The Act of appropriation, of March 4, 1911,32 provides under certain conditions, for the importation of tick infested cattle from Mexico into that part of Texas below the southern cattle quarantine line.

152. Meat Inspection. The Act of August 30, 1890,33 provides for the inspection of meats for exportation, and prohibits the importation of adulterated articles of food or drink. ${ }^{34}$

The Acts of June 30, 1906, ${ }^{35}$ and March 4, 1907, ${ }^{36}$

3033 Stat. 1264.

3134 Stat. 260.

31a 37 Stat. 831.

32 Public, No. 478.

3326 Stat. 414.

34 Cove oysters are adulterated when they contain an excessive amount of water. Food and Drugs act, judgments 2583 , 2584. Misleading addition of colnring matter may be pro. hibited, such as the addition of annatto to milk (St. Louis v. Polinsky, 190 Mo. 516; St. Louis v. Jud, 236 Mo. 1, 139
S. W. 441), or coloring to dis. tilled vinegar, so that it will represent cider vinegar (People v. William Henning Co., 260 Ill. 554, 103 N. E. 530 ), or the coloring of oleomargarine to represent butter (People v. Arensberg, 105 N. Y. 123; PUBLIC HEALTH, 465). Milk, oysters, and other articles of food are frequently condemned as adulterated on account of the presence of bacteria.

3534 Stat. 674.

3634 Stat. 1200. 
provide for systematic supervision of the meat production by the Department of Agriculture; provides for post mortem examination by inspectors of the Department, and the exclusion from interstate or foreign commerce of such meats or meat products as show evidences of disease, preservatives, coloring matter or disease producing substances.

The Act of October 3, 1913, ${ }^{37}$ provides for the importation of certain articles free of duty, but subjects imported meats to examination.

The Food and Drugs Act of June 30, 1906, ${ }^{38}$ provides for the exclusion of articles from interstate or foreign commerce on account of mislabeling, or for adulteration. The administration of this act is in charge of the Bureau of Chemistry of the Department of Agriculture.

153. Intrastate Meat Industries. Only a little over one half of the animals slaughtered in the United States are slaughtered under federal supervision. In 1907 it was estimated that approximately 5,000,000 cattle, 8,000,000 sheep, and over $10,000,000$ hogs and 3,000,000 calves were slaughtered by butchers in this country without federal supervision, and most of them without any efficient supervision at all. Added to these should be $1,500,000$ cattle, $1,000,000$ sheep, and $16,500,000$ hogs slaughtered by farmers. Approximately two per cent of carcasses examined by federal officers are condemned, and it may easily be seen that the percentage of animals slaughtered for intrastate consumption which should be condemned would be much greater. The federal government is with- 
out authority in the matter of animals slaughtered for consumption within the state where slaughtered. Many of these local establishments are unsanitary in construction, and arrangement, and facilities for satisfactory examinations are almost totally lacking. The result is that the intrastate meat industries are conducted in a most unsatisfactory manner, and their products are lacking in governmental endorsement. Because they are conducted in a cheap manner, lacking in sanitary precautions, and also because there is less loss through rejection of unfit carcasses, these uncontrolled establishments can undersell the reliable products. Because they sell cheap meats local interests frequently oppose regulation of the trade.

154. Municipal Control. Ordinances regulating the location and operation of slaughterhouses, and regulating the sale of meat products, are frequently enacted by municipalities, under the general provisions of charters and state statutes. Such ordinances are only partially effective, and they may be void because of unjust discriminations and restrictions of trade. ${ }^{39}$ They may be set aside as unnecessarily onerous on account of the fees charged, and because not strictly health regulations. ${ }^{40}$

Such municipal ordinances are only justifiable in the absence of state regulation of the industry. They are generally inefficient, and the requirements of adjoining municipalities may be conflicting.

39 Armour \& Co. v. City of Augusta, 134 Ga. 178, 67 S. E. 417.
40 Brimmer v. Rebman, 133 U. S. 78 . 
155. State regulation. Efficient regulations should be made in every state by statutory enactment, providing for a strict supervision of all intrastate meat industries, on the same general plan as that maintained by the federal government. But state laws requiring the inspection of animals within the state before slaughter will be considered as an unconstitutional interference with interstate commerce in the matter of meats shipped in under supervision of the federal government. ${ }^{41}$ Such laws may be enforced only with regard to meat slaughtered within the state.

156. Common Law Regulation. By the common law one who sells articles of food does so on the implied warranty that they are wholesome; and if they be not so an action lies for such damages as may be shown. ${ }^{42}$ Under this common law principle a dealer may be assessed damages for the sale of unwholesome food, for the offering of it for sale is an implied warranty of its goodness. ${ }^{43}$ But such warranty does not operate where the purchaser selects the article, and no artifice has beell used to hide defects. ${ }^{44}$ Where the injurious articles are not subject to previous inspection, as in canned goods, the seller, or the manufacturer may be held for the damage suffered. ${ }^{45}$

41 Minnesota $\vee$. Barber, 136 U. S. 313 ; Brimmer v. Rebman, 138 U. S. 78.

42 Blackstone, III, 165.

43 Winsor v. Lombard, 18 Pick. 57; French v. Vining, 102 Mass. 132, 3 Am. R. 440.
44 Farrell v. Manhattan Market Co., 198 Mass. 271, 84 ‥ E. 481,15 I. R. A. (N. S.) $8 S 4$. 45 Mazetti v. Armour \& Co., 75 Wash. 622, 135 Pac. 633; Bigelow v. Maine Central R. R. Co., 110 Me. 105, 85 Atl. 396. 
BIOLOGIC SUPERVISION.

157. Biologic Products. In modern therapeusis and prophylaxis, both for man and beast, various biologic products have become of very great importance. The peculiar nature of these substances readily offers itself as a means for working great harm, as well as great good. Through accidental infections they have already caused many deaths of human beings, and have caused the nation tremendous financial losses by the introduction and spread of animal diseases. To safeguard the public as much as possible the federal govermment has seen fit to exact licenses from all those engaged in the manufacture of such articles designed for interstate traffic, and under the license system to supervise the processes of manufacture. This is in charge of the Public Health Service of the Treasury Department, but the services of veterinarians is required in the examination of animals used for this purpose. The manufacture is conducted under the strictest surgical technique, and every operation is safeguarded as much as possible.

158. Governmental Responsibility. The govermment does not guarantee the purity of the product. Neither did the label "Guaranteed under the U. S. Pure Food and Drug.s Act" mean that the government guaranteed the contents of the package. That label simply meant that under the provisions of that act the maker guaranteed the genuineness of his product as marked. In point of fact many manufacturers and dealers have been prosecuted by the government because they attempted 
to use this method for misleading the public. Though the national government thus tries to protect the citizens in their lives and property, it does not in the least relieve the manufacturers and dealers from their responsibility and liability. It is the part of the government supervisors to check any suspicious tendencies, but the real liability rests with the manufacturing company. Some companies have learned this lesson, but some others still seem at times willing to take risks which should not be run. There should be no diphtheria antitoxin sent out where there is a possibility of there being tetanus infection in the serum; nor hog cholera serum until tests have shown the absence of the foot and mouth disease virus. One serious outbreak of tetanus occurred through virus manufactured under a municipal health department, "to save money," and not under federal supervision. This is not a business for non-experts to engage in. So long as the highest degree of care and diligence is used the manufacturer will be protected by the courts; but if, to reduce expense, or because of commercial pressure, it be shown that he "runs the risk" and harm results, he should be prosecuted criminally, and he should also be forced to pay full damages for the harm done. A firm manufacturing vaccine virus rented calves for that purpose. After collecting the vaccine serum the calves were returned to the renters, sold and shipped to distant parts, infected with the foot and mouth disease virus through vaccination. Under the present orders of the Public Health Service such an accident is less likely to recur, because in addition to testing 
each lot of virus the calves are now slaughtered under governmental supervision, and subjected to careful scrutiny.

If a governmental inspector or supervisor, either through unworthy motives, and incentives, or because of carelessness, shall be shown to be negligent in the matter, and permit practices in connection with the business whereby accidental infection to the biologic products enter, and in consequence harm results, such governmental officer or employee may be personally liable for the harm resulting; but the holding of such officer by no means reduces the responsibility of the manufacturer. He may still be prosecuted criminally and civilly. It may be that the damages may be assessed against the manufacturer and the negligent official conjointly.

159. Evidence of Infection. Where infection has occurred, the duty of ferreting out the evidence may, and probably would, devolve largely upon veterinarians. First, it should be detected in those used for the manufacture, either before or after slaughter. Secondly, should it not be detected at the start it must frequently be traced among the subjects upon which the product is used. This, in a large proportion of the cases, will be among the lower animals treated by veterinarians. In these cases, the work of the official veterinarians would be greatly facilitated by certain possible records made by private practitioners.

Where, as in protection against hog cholera, a large amount of serum is used, the veterinarian should make such a record that he can trace the serum used on any particular lot. This is required 


\section{ESSENTIALS OF VETERINARY LAW}

in the case of serum supplied by many states. It is well to use serum from two or more lots at the same time, and when this is practiced they should not be used indiscriminately. When so used it would be practically impossible to trace the infection should harm result. On the other hand, a "control" test may offer efficient aid. For example: Suppose a veterinarian has lots of $\mathrm{X}$ and $\mathrm{Y}$ serum, enough to treat herds of $A$. and $B$. If he used the lots of serum indiscriminately, and disease broke out soon after, there would be little to show that the disease was due to the use of either lot. If $\mathrm{X}$ were used only on the $\mathrm{A}$ herd, and $\mathrm{Y}$ on the $\mathrm{B}$ hogs, the occurrence of foot and mouth disease in the $\mathrm{A}$ herd would point to the $\mathrm{X}$ serum as a possible source. But if $\mathrm{X}$ were used on the $A$ herd except two or three animals, on which $\mathrm{Y}$ was used; and $\mathrm{Y}$ were used on the $\mathrm{B}$ herd, except a few on which $X$ were used; then if the disease occurred only among the A herd, irrespective of the serum used, it wonld indicate that the disease was not due to the serum; but if it shorred first in the $\mathrm{X}$ animals of each herd it would be strong evidence of infection in the $\mathrm{X}$ serum. In such use of two lots the exceptional animals in each herd must be clearly and surely indicated in the record.

If in addition the veterinarian made a practice of reserving one package from each lot used, for a period of from fifteen to thirty days, there would be a possibility of surely demonstrating the quality of the article. There is another, and a selfish reason for the reterinarian adopting this practice. If after the use of serum, septicaemia breaks out 
among the animals, he may be morally certain that it was due to the serum used; but the company will be just as sure that it was due to the operator's lack of care. A reserved package, kept properly cold, will be the means of demonstrating the truth. Without that evidence his own reputation as a veterinarian may be lost, and he may be held in civil damages for the harm done through his alleged malpractice. This was the defense of one manufacturing concern in a suit for damages, and the court found the company not liable. 


\section{CHAPTER VIII.}

EXECUTIVE ORGANIZATION.

§165. American Executive §172. License Appeals.

System Unsatisfactory. $\$ 173$. Health Preservation a

\$ 166. Executive Boards.

\$167. A Trained Executive.

\& 168. Paid Executires.

8169 . Permanency of Office.

$\$ 170$. Veterinary Science and the Medical Profession.

Function of the State.

$\S 174$. Organization of a Health

Department-State.

$\S 175$. Local Organization.

$\S 176$. Records.

$\S 177$. Reports.

$\S 178$. Guidance of Legislation.

\$171. License Examiners.

\section{American Executive System Unsatisfac-} tory. Although Americans have the reputation of being highly efficient in business, they fail to show evidences of such a character in the executive departments of state and municipal governments. There are several reasons for this. One is that the people generally have not amakened to the fact that governmental business, like commercial enterprises, requires special training and experience for each branch of the work. Americans show a certain egotistical conceit in thinking that any one can serve in any kind of an office, and that each citizen has a sort of right to a chance at the public treasury. The "spoils" system, with the frequent changes of the occupants of office, is emphatically hostile to efficiency. What business house could survive if every two or three years it 
discharged a majority of its employees, and put in raw talent? In ordinary manufacturing or commercial business those at the head are selected from those who have spent years in working up from the bottom of the ladder. The head positions are rightly regarded as the important ones. In American governments it is the custom to appoint men to the responsible positions who have never had any experience in the government. For a time even the subordinates who are retained are demoralized, and work is paralyzed. Before those in the higher positions have really learned their work they give place to others, and the process of adjustment begins again. With such a system efficiency is a practical impossibility. ${ }^{1}$

166. Executive Boards. Another serious drawback to efficiency is found in the existence of executive boards. Absolutely nothing can be said in defense of the idea. Executives have no legislative authority. It is the business of executives to act, and to administer the laws as found. A board is very different from an executive council, in which the chief calls his subordinates together for an interchange of ideas, and to harmonize the work in different portions of the department. Such councils are often necessary for purpose of efficient orientation as to conditions. A board is composed of members equal in authority and responsibility. It is true that for parliamentary practice they may elect a chairman or president, and a secretary to whom may be intrusted special duties and responsibilities; and they may have an executive, who

1 See Public Health, Chaptor IV. 
may be specially fitted for his position; but essentially the members are enclowed with, not only equal power, but also equal irresponsibility and equal lack of authority. In consequence, the work of boards shows a lack of vigor, expedition, and certainty of action, which are necessary for efficiency in executive performance.

Added to these inherent objections to the idea, a board is generally composed of citizens who devote only a portion of their time to their official duties, often without pay, and they are generally also without special training or education which would fit them for their special service. What is worth having is always worth paying for. It is puerile to expect a man to neglect his private affairs to attend to business which others can do as well as he, and for which others have quite as much legal responsibility. In consequence, though the members may be punctual in attending to the meetings of the boards, they come unprepared for the work before them, and waste much time in talking over matters upon which none of the board is posted.

Every one knows that for a well posted man to be obliged to consult one less informed before action must impede efficient administration; yet that is the essence of the American and English "board" idea. Every member of a board is an obstructionist in executive efficiency in proportion as he is less competent than the one most competent.

An attempt is made, especially in English boards, to obviate this weakness by employing or appointing a competent executive, but under this 
plan the competent man is made subject to the untrained board. An illustration of this employment of trained specialists is the veterinary inspector, frequently a part-time official, "who must be appointed by the county councils, the City Corporation, and the councils of boroughs with a population exceeding 10,000 at the census of 1881, and the Hove urban authority, who are the authorities under the Diseases of Animals Act, 1894." ${ }_{2}$ Although the English system has been greatly simplified within the past three decades, the machinery is still complicated and cumbrous, taking time for its operation. There was a time when there was "one authority for every privy and another for every pigstye; but with regard to the privy, one authority is expected to prevent it being a nuisance and the other to require it to be put to rights if it be a nuisance." 3 Still, with the multiplication of boards, more or less conflicting in authority, and with an attempt to delegate the authority to committees which can be called together more easily than the boards, even the appointment or employment of trained specialists fails to create efficiency.

The executive has no authority in himself. Where the use of judgment is required a board cannot lawfully delegate its power to such an executive, even if he be one of the members of the board. ${ }^{4}$ If a question comes up for the executive when the board is not in session he should legally

2 Bannington, English Public Health Administration, p. 101.

3 Quoted by Bannington, Op.
4 PUblic Health, 272; also see $\$ 9$. eit. p. 9. 
postpone all action until the board meets. $\mathrm{He}$ cannot even take the consensus of the members. They must meet to act. ${ }^{5}$ If he takes the responsibility of action be may do so only at his peril, and if harm or injury results to any one through such illegal though possibly advisable action, he may be held personally liable, if after the board meets they fail to support him in his act, and take the responsibility upon themselves. ${ }^{6}$

Modern business methods demand that responsibility be definite with each person engaged in its operation for some particular portion of the work, and that there be no portion of the work which is not clearly the duty of some one person to perform. It would be just as advisable and practical to entrust the operation of a pumping station to a board of amateur engineers, or so to construct an automobile that each occupant would have an equal control over its movements, as it is to expect a board to be efficient in governmental administration.

167. A Trained Executive. Another serious fault in American executive administration is the failure to recognize the necessity for special education and training previous to appointment to office. This is particularly true of positions requiring special technical knowledge. 'To some degree this is recognized in certain lines of work. For example, it is customary to make a knowledge of the law requisite for appointment or election to the judicial bench. Some knowledge of the law

5 Public Health, 295.

- Public Health, 360, 365, 366. 
is far more general than the knowledge of such a science as that of the veterinarian, or the sanitarian. The mere fact that a physician or a veterinarian has to do with diseases is no indication that he has a personal fitness, or professional knowledge which would fit him for the supervision of public health protection, either for man or beast. It is a special line of work for which there is little scope today except in governmental administration.

Although public health is more generally taught in veterinary schools than in the schools for the education of ordinary physicians, the private practice is diametrically opposed to that of health protection. The private practitioner does not get lis chance for employment until health protection has failed. In consequence there is a distinct difference in the line of thought and action of the health defender from that of the treater of disease. Though the persons may be on the most friendly and sympathetic terms, the two sciences are opposing in essence. Though in subordinate positions it may sometimes be advisable to employ the part time services of those otherwise engaged, the head of the department should be a full time governmental executive.

168. Paid Executives. If efficiency demands the full time of a specially trained and educated man, it follows that he should be paid enough to make it an inducement for him to serve the public generally, rather than to depend upon private patronage. The government is continually losing the services of men who have proved their efficiency because private interests frankly acknowl- 
edge the fact that a good man is better worth his salary though large, than the poorly equipped man is his pittance. The penny-wise legislators are inclined to believe that so long as any one can be induced to take an office for small pay, the pay should not be raised. The consequence is that the office must be filled with incompetent men or those who seek to make up the deficiency through doubtful means. There are many ways of using a free office for the personal advantage of the holder, and low salaries in govermmental work always put a premium npon dishonesty.

169. Permanency of Office. Since governmental work demands qualifications for which there are small demands in private life, it follows that a competent departmental executive should hold his office so long as he proves efficient. He should not be subject to removal with every change in administration-that tends to attract his attention from his executive business to politics. It often perverts his administration in order to secure or hold political support. A Canadian judge is not even permitted to vote at an election, in order thus to keep him clear of political entanglements. There should be no admixture of health administration with political party contests. It is true that sometimes a party may very properly make public health one of its party planks, but the man who holds an executive position in the government should be permitted to devote his full attention to health protection, if that be his particular field of operation.

170. Veterinary Science and the Medical Profession. The members of the general medical and 
the veterinarian professions fail to realize commonly that they are all really engaged in the same work. Formerly veterinarians came from the ranks of the blacksmiths or farriers, just as surgeons were formerly the barbers. Both were formerly regarded as on a lower plane than physicians, but time has shown the intimate relationship which exists between the three. There is less real difference between the work of the human practitioner and the veterinarian than there is in the scope of the veterinarian's work. The veterinarian is called upon to treat canary birds and elephants, and his treatment must vary in consequence. Bacteriology and surgery are essentially one for human beings and for the lower animals, and drug dosage must vary with the species of the patient.

Besides this, in health protection human beings are as much interested in disease prevention among certain animals as they are among human beings, even when the object is solely for the defense of mankind. It is for this purpose that veterinarians are employed for the inspection of the meat industry. Doctor's who have only studied human beings are not competent to pass upon the liealth of cattle, sheep and hogs, nor to detect any but gross lesions in meat carcasses. On the other hand, the study of human epidemiology has opened a new field for the veterinarian to explore among animal diseases. There is an essential oneness between the two fields of endeavor which must be recognized in practice. In this connection it may be interesting to note that in law digests the two professions are today considered and treated as 
one, and to look up a point in veterinary law one must turn to the heading "Physicians and Surgeons."

Because of the essential oneness of these two fields of work, and to reduce duplication in work and equipment, efficiency demands that the two must be under one administration. This does not mean that the human physicians must be subject to veterinarians; nor that veterinarians must be under the supervision of those who deal with human beings. The head of the department should be one who is most familiar and efficient as an administrator in the entire field of health protection. He should not be a physician, nor a veterinarian, nor an engineer, as such, but he should be selected for his knowledge and ability in all the fields, in general. The particular questions arising in some special field he should be able to settle if given the time; but in practice he will depend upon those specially chosen for their knowledge of the particular field. For example, whether he be an engineer, a physician, or a veterinarian, and a question arises pertaining to veterinary practice he will leave it to the veterinarian in charge of that department except in so far as other departments may be involved. If it refers to both human and animal diseases he will leave it for the separate decisions of the two, and with those heads he will act as a harmonizer.

171. License Examiners. Though it is true that efficiency cannot generally be obtained by board organization, there come special questions which must depend for just decision upon the consensus of the minds of several. Much depends in the pro- 
tection of the health and lives of animals and men upon the competency of the practitioners of both classes. The determination of this fitness is therefore a normal portion of the work of a health department. This is generally determined either by the registering of a diploma from a recognized school, or by an examination before a board. When it is simply a registration of a diploma it is a purely executive act, and needs no special organization. An examination is a quasi-judicial act, though performed in an executive department. Competent examiners are not generally such men as are fitted for ordinary executive business. It happens, therefore, that examiners are generally chosen from the ranks of the profession into which the applicant seeks admission. They must each be a man of judicial temperament, and specially qualified according to the most advanced knowledge of some particular portion of professional knowledge. A board of surgeons is not competent to examine a man's knowledge of medicine; nor one of eye specialists to decide as to a man's competency in obstetrics. The board should therefore be made up so that each field of the practice will be covered by some member who is well edueated in that field. ( $\$ \S 30-38$.

Examiners should not be connected, either directly or indirectly, with an educational institution granting diplomas in that profession. Such men, even when honest in intention, are inclined to unduly favor certain schools.

Examiners should be paid for their work for the public good. This does not mean that they should be paid large fees, but that they should 
be so paid that they will not lose too much in attending to the public business. Neither should they be compensated in fees, for that will block efficiency ofttimes by making it an inducement, when reciprocity of license is possible, for them to be easy in their tests, in order to attract candidates for examination who will later take reciprocal licenses in another state. Tests for license must be based upon the law of supply and demand: that is, the public should be entitled to a full supply of the most competent. In a section where there are very few really competent veterinarians the standard should not be so high as where the profession is already crowded.

Licenses should not be issued by the board of examiners, but in the name of the head of the department, to whom the board should report. In this way, the only dealings of the members of the board of examiners with the applicant would be in the examination itself.

172. License Appeals. It sometimes happens that a candidate feels that he has been unjustly treated in an examination. Instances have been known where the evidence showed at least a very strong presumption that the claim was well founded, and that the results were influenced by corrupt motives on the part of one or more of the examiners. Such applicants should have an opportunity of appeal to some one competent to decide the matter. The courts have no jurisdiction, unless a question of law be involved; and a governor having no scientific knowledge of the subject is therefore unfitted to make a decision. With such an arrangement as here proposed there is provi- 
sion for appeal, either to the head of the department, or to a special board composed of the heads of the various examining boards of the department, presided over by the chief executive of the department.

173. Health Preservation a Function of the State. The matter of health protection is strictly a governmental problem, and as such it is the function of the state. Even when it is in the care of city officials it is not municipal business, but it is work entrusted to the city to do for the state. So far as possible, therefore, it is necessary for efficiency that the local administration be supervised by the state office.

Not only is the preservation of the public health an affair and function of the state, but the citizens in distant parts are often quite as much interested in proper local sanitation as the citizens of the immediate community. If there be scarlet fever in a dairy district the neighbors know it, and may guard against the infection; but the residents of the city where the milk is used are unable to protect themselves fully. It is therefore more important to the city residents, in this case, than for the farmers in the dairy community, that there should be an efficient governmental supervision of the matters possibly endangering the public health. On the other hand, the city which discharges its sewage improperly into a stream may thus endanger the farming community further down the stream, and the farmers are therefore especially interested in a proper sanitary administration of the city.

There are many things which might be said in 


\section{ESSENTIALS OF VETERINARY LAW}

favor of our adoption of some modification of a plan used in England to assist in securing good service. There is in London a body called the "Local Government Board." It was created by Parliament to look after matters specially pertaining to localities. Health administration is under its control. Realizing that the smaller communities cannot afford to pay for the services of a competent sanitarian, the Local Government Board agrees to pay one-half of the salaries of certain officers of health and inspectors. It leaves the appointment of these officials to the local authorities, but it stipulates that no officer partly supported by the Local Government Board shall be appointed or removed without the consent of the Local Goverument Board, and it further requires that appointees must present evidence that they are qualified for the position, and that they will devote full time to the service.

The English experience is emphatically to the effect that practitioner's engaged in private work are inefficient public officer's. The Local Government Board therefore makes the requirement emphatic that the appointee shall not be engaged in private practice. In small communities, in order to make it possible to secure such whole-time officers, it suggests that the office be combined with that of medical inspection of schools, or some similar position. Sometimes it arranges a combination of territory, so that one officer may look after a more extended area.

It does not appear that reterinary inspectors are thus partially supported by the state, while holling their positions as local officers. It is true 
that many veterinary inspectors are practitioners, engaged in private practice, and devoting only part time to the governmental duties. At present this is probably unavoidable to some degree; but the same arguments which show the inefficiency of a medical officer of health who is also engaged in private practice must also prove the inadvisibility of part-time govermmental veterinarians where the arrangement can well be avoided.

"No progress at all can be made towards obtaining a skilled democracy, unless the democracy are willing that the work which requires skill should be done by those who possess it." ?

174. Organization of a Health DepartmentState. Copying the methods which have proven successful in efficient commercial organization, the head of the department should be responsible for every portion of the work, and for the efficiency of every sub-officer, and employee. The work should be divided into several bureaus, each of which should have at its head a man specially qualified in that branch. He may be assisted by sub-heads, each responsible for a portion of the work. The division may be made according to subject or to territory, and it should be so arranged as to reduce duplication of labor to a minimum. The same bacteriological laboratory will serve for the investigation of animal and human diseases, for the same principles govern. The department should be interested in study as well as administration, and a very important portion of its scope should be found in education, particu-

i Nill, Representative Gov-

ernment, 248. 
larly by publications and exhibits. The following outline of organization is suggestive:

\section{State Commissioner of Health.}

Assistant Commissioner.

Administrative Assistants.

Infectious Disease Inspector (Human).

Assistants.

County and Local Officers.

State Veterinarian.

Deputy Veterinarians.

Occupational Disease Investigator.

Assistant Investigators.

Lodging House Inspector.

Assistant Inspectors.

Dairy Inspector.

Assistants.

Laboratory Chief.

Chemists.

Bacteriologists.

Pharmacists.

Water Analysts.

Food and Drug Inspectors.

Recorder of Vital Statistics.

Assistants (including provision for collecting statistics relative to animal diseases).

Local Registrars.

Chief Clerk.

Correspondence Clerks.

Accountants.

Librarian.

Records Assistant.

Library Assistant. 


\section{Editor.}

License Council, consisting of one member from each of the license examiners boards, and presided over by the Commissioner.

Examining Board for

Physicians, Surgeons, Midwives, Embalmers, Nurses (and Barbers?).

Pharmacists.

Dentists.

Veterinarians.

Entomologist.

Field Assistants. Sanitary Engineer.

Such an organization would do much to harmonize conflicting interests, would reduce duplication of work, and would increase certainty and definiteness of action. Every possible subject would thus come under the personal responsibility of some one individual, and under the final supervision of the Commissioner.

175. Local Organization. Except in the larger cities the local organization would normally be much more simple. Generally a single full time commissioner, with the aid of a clerk, and a part time bacteriologist, would be able to look after the work properly. For veterinary services such a department would naturally depend upon a deputy state veterinarian. If more be needed he will employ a local practitioner.

The organization in a large city will naturally be upon similar lines to that of the state. The veterinarian department should be distinct within 
the large organization, and the rank of the chief should be next to the Commissioner, or to his assistant.

For efficiency in operation, even when appointed by the municipality, and paid by the same, the local commissioner should be a deputy of the state commissioner, and the local veterinarian should be also a state deputy. It would be better if no local commissioner of health be appointed without the previous approval of the state commissioner, and that no local veterinarian be appointed without the approval of the state veterinarian.

According to a plan tried out in Massachusetts under the supervision of Professor Phelps, several neighboring communities united to establish a joint health office, employing the services of three or more persons. To aroid possible legal questions one may be the officer of one community, and another that of another town, but in actual work one may be the practical chief, another may look after dairy and bakery inspection, another be the veterinarian, and another the bacteriologist. A similar plan has been tried at LaSalle, Illinois, and in both it has worked well. It enables each community to have the services of a whole time specialist in each department, and the expense is reduced by decrease in number of laboratories, etc. It would be well if the statutes made definite provision for such establishments, for they are an evident improvement upon the present administration in most country communities. A somewhat similar scheme was contemplated in suggestions made some time ago to the effect that the health officer of the county seat be the officer for 
the county, at least in counties having less than 15,000 inhabitants outside of the county seat. Such an office should be supported at least in part by the county.

Whether such combination be made or not in the general health administration of rural districts, it is quite possible, and an evident advantage, for neighboring cities and villages to employ the services of the same veterinarian. Thus it would be more easy to have the full time officer, who may thus devote his entire attention to prevention of disease, rather than a part of the time of one whose real interest is in another field of study.

The man whose living depends upon his treatment of either human or animal diseases finds that his private business is most urgent, just when his official duties are most pressing-during epidemics. Self-interest compels him to neglect his public work.

176. Records. Records of the offices should be so kept that at any time those responsible will be able to tell the exact condition of affairs undel their supervision. The local commissioner should know just how many cases there may be of infectious disease in his jurisdiction, and where located; and by means of his reports similar information should be obtainable in the state office.

177. Reports. The outbreak of any infectious disease in a locality should be at once announced to the state office, those for animal diseases going to the state veterinarian. There should, in addition be weekly reports showing the number of new cases, number recovered, and number deceased. 
In case of the removal of a case of infectious disease to another locality, or of suspicion that a local case arose through infection from another jurisdiction, immediate reports should be made to the state office and to the other locality interested. Also, where infectious disease is found in a dairy district, even when unassociated, so far as known, with the dairy business, notice should be sent to the officials in charge of the jurisdiction where the milk is sold.

178. Guidance of Legislation. It is the business of the executive to administer, not to enact the laws, but he also has a most important legislative duty, and a duty which is especially important in such matters as the prevention of disease. It is the executive who first meets with the problems, and he is peculiarly able to decide how they should be met. Our governmental system does not permit him to enact laws, but often he may accomplish the same end by orders based upon laws already enacted. The advantage of these special regulations and orders is that they can be easily modified to meet changing conditions.

According to the laws of many states it is the duty of certain executives to recommend certain legislative changes. It is thus his duty, whether so ordered by law, or only by common sense, to make occasional reports which will set forth clearly and concisely the reasons why an enactment should be made, and what law should be passed. It is not the right of the executive to demand the legislation, but to report the needs, and the suggestive form. The legislative responsibility rests 
with the legislature of the state (or the council of a city). This fact must be fully recognized by the executive.

The executive should also keep posted as to any changes in the laws contemplated by the legislature, which might affect his peculiar field of interest. If he detect faults, he should first try to convince the legislators of the fact. Failing in that he might possibly be justified in publishing his criticism. He should not be a lobbyist, nor a $\log$ roller. 



\section{PART IV PERTAINING TO ANIMALS GENERALLY}





\section{CHAPTER IS. \\ OIINERSHIP OF ANIMALS.}

$\S 185$. Wild or Domestic Animals.

\$186. Animals Ferue Naturae. $\S 187$. Dead Animals.

\$188. Qualifications.

$\S 189$. Dogs.

$\S 190$. Ownership of AnimalsHow Obtained.

$\S 191$. Estrays.

$\$ 192$. Sale of Animals.

$\S 193$. Warranty of Soundness.

$\S 194$. Illustratice Cases of Unsoundness.

$\S 195$. Warranty of Character. $\S 196$. Bill of Sale.

$\S 197$. Ownership of Increase.

$\S 198$. Proof of Ownership.

\$ 199. Marks and Brands.

$\S 200$. Sale of Brand.

$\S 201$. Altering of Brand.
8 202. Wrongful Branding.

$\S 203$. Driving from liange.

$\$ 204$. Breeding.

$\S 205$. Service Fees.

$\S 206$. Warranty of Sound Heredity.

$\S 207$. Insurance of Get.

$\S 208$. Liens for Service.

$\S 209$. Liability of Owner of Stallion.

$\S 210$. Gelding a Stallion.

$\S 211$. Liability of Owners of Animals.

8212. Obligation to Restrain Animals.

§213. Barbed Wire Fences.

$\S 214$. Frightening Animals.

$\S 215$. Liability for Injuries on the Public Highway.

175. Wild or Domestic Animals. In law a distinction is made in the ownership of different kinds of animals. One may have an absolute ownership in such domestic animals as the horse, cow, sheep, and hog. The law gives him full protection in such ownership. The ownership of dogs is different. Dogs are called qualified property in the common law, under the idea that they are normally animals ferae naturae, that is wild animals, which have been captured and tamed. By the laws of many states dogs are made property; but 
we have very many decisions which insist that a dog is property only while within the provisions of the law. Thus, when the law says that a dog must be licensed, or must wear a collar, or must wear a muzzle, if the thing required by law is omitted by the owner in the care of his dog, the animal will not be considered within the protection of the law. ${ }^{1}$ When the owner fails to comply with the law as to how the animal shall be kept, the law may provide for the summary destruction of the animal. ${ }^{2}$ The Vermont statute provided that dogs must be licensed and wear collars. A dog not wearing a collar was pursuing deer, and the owner of the place shot the dog. It was shown that ordinarily the dog did wear a collar and that he was licensed. The court held that the statutes having required the license and collar, the landholder was justified in shooting and killing the dog, and that no form of judicial proceedings was necessary. Further, that the motive of the killer was immaterial. ${ }^{3}$ On the other hand, no owner of property has an ownership or property right in the deer on the place during the closed season. A beagle hound does not pursue deer, and the fact that a beagle hound was in the deer preserve wonld not justify killing him under provisions for the protection of deer. ${ }^{4}$

1 Sentell v. New Orleans, etc. R. Co., 166 U. S. 698; Cranston v. Mayor of Augusta, $61 \mathrm{Ga}$. 572.

2 Campau v. Langley, 39 Nich. 451; Blair v. Forehand, 100 Mass. 136.
3 McDerment $\nabla$. Taft, $83 \mathrm{Vt}$. 249, 75 Atl. 276.

4 Zanetta v. Bolles, 80 Vt. 345, 67 Atl. 818 . 
186. Animals Ferae Naturae. Wild animals are called in law, "animals ferae naturae." As such they are not subject to ownership. When captured and confined, or when tamed, they are regarded as qualified property. "No one can acquire an absolute property in animals ferae naturae, but the ownership of such animals is at most a qualified one, and belongs to all the people of the state in common." 5 The state may therefore protect such animals by statutes, prescribing the times and manner for their killing; ${ }^{6}$ and it may prohibit the killing of certain animals, or killing them during certain months; and such prohibition includes such game raised artificially in captivity. ${ }^{7}$

187. Dead Animals. Animals ferae naturae may be made property by killing. They thus become the property of the hunter, and by him may be sold, if the law does not forbid such transfer of property right. In some states each hunter is limited to a certain number in the killing of game, and he may not sell game to any one. Property cannot be created contrary to law. ${ }^{8}$ The possession of game in the closed season has therefore been held to be illegal, ${ }^{9}$ even when the property right was established by killing in the open season. This is also true where the game has been shipped in from another state, ${ }^{10}$ but the New

S State v. Niles, 78 Vt. 266 , 62 Atl. 795, 112 Am. St. R. 917.

6 Geer v. Connecticut, $161 \mathrm{U}$. S. 519 .

7 Commonwealth v. Gilbert, 160 Mass. 157.

8 P U B I C H E A T H, 187 ; Frennd, Police Power, 528.

9 Phelps v. Racey, $60 \mathrm{~N}$. Y.
10; Smith v. State, 155 Ind. 611 ; 58 N. E. 1044 , 51 L. R. $\Lambda$. 404 ; State v. Rodman, 58 Minn. 393, 59 N. W. 1098.

10 Merritt v. People, $169 \mathrm{Ill}$. 218, 48 N. E. 325; Ex Parte, Maier, 103 Cal. 476, 37: Pac. 402, 42 Am. St. R. 129. 
York court held such a law unconstitutional, as being an interference with the power of Congress over interstate traffic. ${ }^{11}$

But death of a domestic animal does not terminate the owner's property right in it, and while it may be required that the carcass be so disposed of that it will not become a nuisance the municipal authorities cannot arbitrarily deprive him of his property by giving it to another. ${ }^{12}$ These were both cases relating to dead dogs.

188. Qualifications. Cats, birds, and wild animals are regarded in the same class, though special statutes have been passed, as in Wisconsin, making such animals subjects of larceny. According to the English law, game animals on a preserve are recognized as qualified property of the owner of the land, but that custom has not been prevalent in this country. However, the killing of game upon private property may be regarded as trespass and punished accordingly. Where the game has been captured and kept in captivity the property right would be recognized; but if the animal escaped from confinement property right would probably be considered as doubtful.

189. Dogs. The legal decisions relative to the right of property in dog's in this country show a gradual development. In the earlier decisions we were told that property in a dog was base property, regarded as property for certain purposes only, and entitled to less consideration and protec-

11 People v. Buffalo Fish Co., 164 N. Y. 93,58 N. E. 34.

12 Campbell v. District of Columbia, 19 App. D. C. 131;
Vantreese v. MeGee, 26 Ind. Аpp. 525, 60 N. E. 318. PuBidC Health, 450. 
tion than other domestic animals. ${ }^{13}$ Then it was said that it is not necessary that a dog have real pecuniary value in order to render him subject to ownership. ${ }^{14}$ Gradually it came to be recognized that a $\operatorname{dog}$ is personal property with a value..$^{15}$ Today the character of the $\operatorname{dog}$ as property is acknowledged by statutes and practice.

Under the old idea, to the effect that a dog was only property while being kept strictly according to the law, it was nevertheless held, that a provision in a statute that any person may kill a dog found without a collar does not make the lack of a collar such evidence that the dog has no owner as will authorize a person to convert such dog to his own use. ${ }^{16}$

Though dogs are only qualified property they are recognized as property in so far as that the owner may be held liable for injuries inflicted. A knowledge of previous bitings is sufficient to require of the owner that he take special care; ${ }^{17}$ and if there be any suspicion that the animal may have hydrophobia he should take particular care to prevent bitings. ${ }^{18}$ If it be shown that the owner has not exercised due care under the circumstances, he will be held in civil damages for the

13 Maclin's Case, 3 Leigh, 809; Woolf v. Chalker, 31 Conn. 121, 81 Am. Dec. 175; Davis v. Commonwealth, 17 Grat. 617; Cole v. Hall, 103 III. 30 .

14 Parker $\nabla$. Mise, 27 Ala. 480, 62 Am. Dec. 776.

15 Anson v. Dwight, 18 Iowa 241; Heisrodt v. Hackett, 34
Mich. 283, 22 Am. S. Rep. 529; Nehr v. State, 35 Neb. 638, 53 N. W. 589, 17 L. R. A. 771.

16 Cummings v. Perham, 42 Mass. 555.

17 Mayer v. Kloepfer, 69 Atl. 182.

18 Buck v. Brady, 110 Md. 568, 73 Atl. 277. 
full amount of the injuries inflicted. Where a small dog joined with a hound in chasing sheep, and participated throughout to the best of his ability, his owner was liable, though the hound reached the sheep first and inflicted the more serious wounds. ${ }^{19}$ Any one may kill a mad dog, or one supposed to be mad, or exposed to the infection, ${ }^{20}$ but there must be good and sufficient reason for so considering the animal. This rule would not justify the killing of a dog just because he may possibly have been exposed to the danger, or because he may have chanced to bite a person or another animal. There is no universal rule which will hold the owner of a dog liable for biting either person or other animal. ${ }^{21}$ The dog may have been worried, or it may have been moved with some sudden and unexpected emotion, though habitually quiet and good natured. Or the animal may have been within his legal rights, as where a dog kept to protect an automobile bites a person attempting to get into the rig, or to take something from it, or when a watch dog bites a trespasser upon property.

190. Ownership of Animals-How Obtained. A property right in animals may be acquired by purchase, by gift, by inheritance, by finding and capture, or by natural increase. Animals ferae naturae may become property by capture and subjugation, including killing. Property acquired by inheritance is a matter of record in probate pro-

19 Johnson v. Lewis, 151 Wis. 21 Kelley ₹. Tillourey, 81 615,139 N. W. 377. Conn. 320, 70 Atl. 1031.

20 Brent v. Kimball, 60 Ill. 211. 
ceedings. A gift implies the existence of a donor, and his will to transfer ownership, a thing to be transferred, a receiver of the gift and his acceptance of the same. The gift may be annulled at any time up to that at which it has been accepted. The fact that the giver has presented it, either formally in person, or in writing, does not transfer ownership. The gift must be accepted, and in a question of doubt this acceptance should be shown by some act or record. The acceptance by the natural guardians of an infant may be suffcient for his protection of a gift. For a parent to say to his son "you may call that colt yours" may not be sufficient for the transfer of ownership. In case of question the parent must be able to show that the colt was in fact regarded as the property of the son, and that it was so regarded universally in the family. In as much as such questions are very liable to come to the surface when some attachment or levy has been made on account of the parent, and such a claim then gives rise to suspicion; and because of the possible question of right of ownership in animals sometimes becomes serious; it would seem that every such gift should be a matter of record, and that the record should be preserved by the person to whom the animal is given. This record may be an entry in the books of a parent presenting the animal to his child, and describing the animal so that others could identify it; or it may be better made in a note which can be handed to the child, or preserved for him, and after describing the animal or animals given, further state the terms of a gift. Does the parent intend to give only the animal, and let the child 
pay for its pasturage and barn feed, or does the parent also give these items until such time as he shall give formal notice of the withdrawal of such privileges?

Sometimes an animal is turned over to a friend to be kept and used as his own, subject to future taking back. Such an animal may acquire a reputation in the community as the property of the friend. Possibly the friend may honestly understand that the animal was a gift, whereas the donor only intended to confer the use of the animal. Perhaps the animal loaned might be a valuable mare, temporarily out of commission for the owner's use, and in the time she was in the care of the friend she gave birth to a valuable colt. The ownership of that colt might be much more valuable than that of the dam, and when the question is raised neither conld tell surely the terms under which the friend took the mare; and the memory of the two persons interested might differ. To prevent possible misunderstandings and possible unnecessary expense of litigation, the gift of an animal to another should always be accompanied by a statement in writing; and the acceptance of an animal in trust for more than a temporary period should be marked by a receipt given by the bailee, and telling the terms under which it is accepted. (See Chapter X.)

191. Estrays. The finder of property has an ownership right in the thing found as against every one but the lawful owner. Since cattle and other animals are liable to escape and become lost, it is customary for the different state legislatures to prescribe how such property shall be retumed 
to its rightful owner. In general these laws prescribe a public advertising of the animal taken, and if the owner is known a notice must be sent to him of the fact of finding. Since such an animal must be fed and cared for, the owner is under obligation to pay for the keep and other necessary expenses before regaining full possession. If no one is able to prove ownership, the animal may become the property of the finder if he so wishes. Should the owner refuse to regain possession his refusal may be taken as a gift of the animal to the finder.

If the finder shall have been a party to the escape of the animal, as by leaving a gate open to a pasture, or by driving off animals on a range, or by enticing' a dog from home, he will acquire no rights whatever in the finding, nor for the care of the animal. Where a dog has followed one not his owner away from his home, and has lived with that person until an attachment has been formed for the dog, if the owner has advertised the loss where the finder might reasonably have seen the advertisement, and sought diligently for his animal, whereas the finder has neglected to advertise the taking up of the animal, he will acquire no rights in the finding, nor for his care of the animal while in his possession.

192. Sale of Animals. No animal should be purchased without some writing from the seller to the purchaser. In the case of animals of small value an ordinary bill, receipted, describing the animals sold, may be quite sufficient. In proportion as the property sold is of value this is not sufficient, but a regular bill of sale is to be preferred. According to the old common law "an implied warranty was 
annexed to every sale, in respect to the title of the vendor; and so too in our law, a purchaser of goods and chattels may have a satisfaction from the seller, if he sells them as his own and the title proves deficient, without any express warranty for that purpose. But with regard to the goodness of the wares so purchased, the vendor is not bound to answer; unless he expressly warrants them to be sound and good, or unless he knew them to be otherwise, and hath used any art to disguise them, or unless they turn out to be different from what he represented them to the buyer." 22 The note added to the above quotation is so clear and applicable in the present discussion that it is here added. "Mr. Christian observes, that the following distinctions seem peculiarly referable to the sale of horses. If the purchaser gives what is called a sound price, that is, such as from the appearance and nature of the horse would be a fair and full price for it, if it were in fact free from blemish and vice, and he afterwards discover's it to be unsound or vicious, and he returns it in a reasonable time, he may recover back the price he has paid, in an action against the seller for so much money had and received to his use, provided he can prove the seller knew of the unsoundness or vice at the time of the sale; for the concealment of such a material circumstance is a fraud, which vacates the contract. But if a horse is sold with an express warranty by the seller that it is sound and free from vice, the buyer may maintain an action upon this warranty of special con-

22 Chitty's Blackstone, II, 451. 
tract, without retuming the horse to the seller, or without even giving lim notice of the unsoundness or viciousness of the horse; yet it will raise a prejudice against the buyer's evidence, if he does not give notice within a reasonable time that he has reasons to be dissatisfied with his bargain." ${ }_{23}$ It has often been held that the implied warranty does not bind in respect of obvious and patent defects. ${ }^{24}$

193. Warranty of Soundness. There is an old doctrine of the common law which applies especially to the sale of animals- "Caveat emptor," that is "let the buyer beware." It may be said that the basis of the doctrine, as applied to the sale of animals, is to be found in the idea that men are equally learned and equally ignorant relative to animals. Unless there has been an evident attempt to conceal a defect, or there has been made an express warranty as to character and soundness, there has generally been an agreement in the decisions to the effect that the purchaser of animals must run his own risks. Sometimes the principle has been overworked to a ridiculous degree. The selling of a glandered horse was not considered an illegal act at the common law, even when the seller knew the condition. ${ }^{24 a}$ Where a trade has been made, and one of the parties thus got rid of a glandered animal, it was held that in so doing he was not guilty of such fraudulent act as would require surrender on replevin of the

\footnotetext{
23 Chitty's Blackstone, II, 24a Hill v. Ball, 2 H. \& N. 451 , note 22. 298.

24 Chitty's Blackstone, II, 451, note 22, citing cases.
} 
horse received in trade. ${ }^{25}$ However, the bringing of an animal afflicted with such an infectious disease as glanders into a public place is an indictable offense at the common law, even though the defendant was not aware of the full extent of the contagiousness of the ailment. ${ }^{26}$ Although it was held that the bringing of animals afflicted with an infectious disease into a market, in spite of the prohibition of such bringing of them in, did not constitute a warranty of their soundness, ${ }^{27}$ this doctrine was later very properly reversed by Lord Blackburn, ${ }^{28}$ who held that such offering of the animal for sale in a public place was a practical statement that so far as the owner knew the animal was not so suffering from an infectious disease. It has also been held, we believe wrongfully, that the fraudulent selling of a glandered horse to one ignorant of the fact will not make the seller liable for the death of a person who contracted the disease by coming into contact with the horse. ${ }^{29}$ The court was influenced in this case by the relative infrequency of the accidental occurrence of glanders in human beings, but such a decision would have the effect to increase the frequency. Experience shows, also, that glanders in human beings is frequently unrecognized by attending physicians who have not had special experience with this disease. Cases are diagnosticated per190.

25 Harey v. Petrie, 100 Mich.

${ }^{28}$ Reg. v. Henson, Dears, C. C. 24 .

27 Ward v. Hobbs, 4 App.
28 Bodger r. Nicholls, 28 L.

T. N. S. 441.

29 State v. Fox, 79 I․ 514. Cas. 13. 
haps as tuberculosis, until bacteriologic examination shows the presence of the Bacillus mallei. Human cases are frequently discovered first by veterinarians who have been called to treat animals on the place, and accidentally learn of the human patients.

A glandered horse is today recognized as a danger to the community, and as such the authorities generally order its destruction. It may therefore be regarded as practically worthless for any purpose. It was held in one case that where a horse is worthless for any purpose there is a total lack of consideration, and the trade is therefore voidable, irrespective of the matter of warranty. ${ }^{30}$ "Under the Iowa code, the fact that the buyer of sheep knew that they were afflicted with a contagious disease will not prevent the sale from being invalid; but it is otherwise where the seller did not know." 31 Where the seller of a diseased animal had no special cause for suspicion of the infectious character of the ailment, it was held that the doctrine of Caveat emptor applied. ${ }^{32}$ Where a seller of diseased animals knowingly warranted them free from infectious disease, he has been held liable for the injury to other animals, ${ }^{33}$ even though he did not know that the purchaser

30 Danforth \& Co. v. Crookshanks, 68 Mo. App. 311.

31 Ingham, The Law of Animals, 88, citing Caldwell v. Bridal, 48 Iowa 15.

32 Rothwell v. Milner, 8 Manitoba 472; cited by Ingham, s8.
33 Smith v. Green, 1 C. P. D. 92; Mullett v. Mason, H. \& R. 779 ; Stevens v. Bradley, 89 Iowa 174; Joy v. Bitzer, 77 Iowa 73 ; Faris v. Lewis, $2 \mathrm{~B}$. Mon. 375 ; Jeffrey v. Bigelow, 13 Wend. 518. 
had other animals. ${ }^{34}$ ( $\S 13,112$.) Where the price and charges for delivery were paid, but no delivery was made, it was held that the purchaser could recover the money paid, and the death of the animal after the time for delivery was no defense. $^{35}$

The general rule as to unsoundness, at present accepted, in spite of some few decisions to the contrary in the past, is that laid down by Lord Ellenborough: "To constitute unsoundness, it is not essential that the infirmity should be of a permanent nature; it is sufficient if it render the animal for the time unfit for service, as, for instance, a cough, which for the present renders it less useful, and may ultimately prove fatal. Any infirmity which renders a horse less fit for present use and convenience is an unsoundness." 36

194. Illustrative Cases of Unsoundness. Fraud and deceit are not countenanced by law. An act done in order to hide a defect, and make its detection less likely, is fraudulent in character. A "nerved" horse is particularly unsound, not only because of the foot disease which is thus covered up, but because the cutting of the nerve in the leg is performed in order that the animal may not show tenderness of the foot when it exists. ${ }^{37}$ Bone spavin, even when not accompanied with lameness, is unsoundness. ${ }^{38}$ Crib biting may be only

34 Sherrod v. Langdon, 21 Iowa 518; Packard v. Slack, 32 Vt. 9.

452.

35 Winn v. Morris, $94 \mathrm{Ga}$.

36 Elton v. Jordan, 1 Stark. 127 ; Elton v. Brogden, 4 Camp.
37 Best г. Osborne, Ry. \& Mo, 290.

38 Watson $\nabla$. Denton, 7 C. \& P. 85, Hoffman v. Oates, 77 Ga. 701 . 
a vice; but where it is associated with some physical defect that defect may be an unsoundness, either caused by, or causing, the habit. ${ }^{39}$

Although it is customary to castrate mule colts, the absence of castration will not be considered unsoundness, ${ }^{40}$ though it might be considered as a deficiency, just as an unbroken colt is deficient as compared with one which has been trained for driving. Similarly, though pregnancy may interfere with a mare's usefulness for many purposes, it is not an unsoundness. ${ }^{41}$ Roaring may be a habit. It is not unsoundness, but it may be an evidence of unsoundness, when caused by disease or organic defect.42 The distinction between symptom and the disease is not sufficiently recognized by many judges. A cough is a symptom or evidence of unsoundness, not unsoundness itself. Lameness is not unsoundness, but the evidence of a defect which is unsoundness. While in most cases this distinction may not be essential, in such cases as cribbing, or roaring, the distinction is essential. The older witers made no distinction between roaring and whistling. In practice today a distinction is made, and according to present knowledge roaring is always a sympton of a physical defect-a paralysis of the vocal cord. The symptom may be removed by excision of the defective cord; but though the animal may be

39 Washburn r. Cuddihy, 8 Gray 430; Walker v. Hoisington, 43 Vt. 608; Hunt v. Gray, 35 N. J. L. 227.

to Duckworth v. Walker, 46 N. C. 507 .
41 Whitney v. Taylor, 54 Barb. 536. 523 . 
quite serviceable for an indefinite period, he is still unsound.

A lameness which interferes with usefulness is unsoundness, even temporarily; ${ }^{43}$ and a horse is unsound when one leg is weaker than the others. ${ }^{44}$

195. Warranty of Character. "If a man sells a horse generally he warrants no more than it is a horse; the buyer asks no question and perhaps gets the animal the cheaper. But if he asks for a carriage horse or a horse to carry a female or a timid and infirm rider, he who knows the qualities of the animal and sells, undertakes on every principle of honesty that it is fit for the purpose indicated. The selling upon a demand for a horse with particular qualities is an affirmation that he possesses those qualities." 45

The sale of a stallion or bull for breeding purposes is not necessarily a guaranty of his ability in that direction, especially in the absence of definite information upon that subject. ${ }^{46}$ But where producers and dealers in horses for breeding purposes sell a stallion to one who, to their knowledge, wishes to use him for that purpose, there is an implied warranty that he is reasonably fit for such purpose, ${ }^{47}$ and that he is not prevented by illness, weakness, or any other infirmity from

43 Elton v. Brogden, 4 Camp. 281.

44 Elton v. Jordan, 1 Stark 127.

45 Jones v. Bright, 5 Bing. 533. (Per Best, C. J.) Also, Smith v. Justice, 13 Wis. 600; Danforth v. Crookshanks, 68 Mo. App. 311.
46 Glidden v. Pooler, 50 Ill. App. 36; Taylor v. Gardiner, 8 Manitoba 310; Scott v. Ren. ick, 1 B. Mon. 63; MeQuaid v. Ross, 85 Wis. 492; White v. Stelloh, 74 Wis. 435.

47 Merch. \& Mech. Sav. Bank v. Fraze, 9 Ind. App. 161. 
being able to exercise his breeding qualities. ${ }^{4 s}$ So where the seller of a bull knew that he was without the power of propagation, but did not disclose the fact, it was held that he was liable in an action for his deceit. ${ }^{49}$ A stallion sold with a warranty as "a foal getter" was held not to fulfill the terms of the guaranty when only eight out of fifty-five mares served were with foal.50 A bill of sale guaranteeing a stallion as a breeder does not imply a guarantee that he is pure-bred. ${ }^{51}$

In regard to the character of the animal it must be remembered that an animal which is gentle and reliable in the handling of one person may be quite the reverse with another, possibly without any apparent reason.

It is very evident from the foregoing that it is for the decided advantage of the buyer that the bill of sale state that the animal is sound, and free from vicious traits; but it is of such decided disadvantage to. the seller that he should not insert such a statement unless he is willing to assume the added responsibility in the matter.

The bill of sale should describe the animal, or animals sold, with as much definiteness as is conveniently possible. Of a horse it should give his age, color and sex, with special marks. Of a flock of sheep it should give the number, breed, number of sheep in each class (ewes, rams, etc.), with special marks. Of cattle on the range, in addition

48 Budd $\nabla$. McLaughlin, 10 Nanitoba 75 .

49 Maynard v. Maynard, 49 Vt. 297.

50 McCorkell v. Karhoff, 90
Iowa, 545; Brown v. Doyle, 69 Minn. 543.

51 First National Bank v. Hughes, 5 Cal. U. C. 454,46 Pac. 272. 
to such points as are indicated for sheep in pasture it should tell where the cattle are running.

All encumbrances upon the title to the animals, including possible liens, should be stated in the warranty which the bill of sale is. If an animal has a name, as of a horse, it should be given.

196. Bill of Sale. The following is a convenient form for a bill of sale:

Know all men by these presents that I, ......., of........., in the county of........., and state of........., in consideration of......... dollars to me paid by.........., of.........., in the county of........., state of........., the receipt whereof is hereby acknowledged, do hereby grant, sell, transfer and deliver unto the said.........the following animals, namely:... .............. to have and to hold, all and singular of such described animals to the said .........., and his executors, administrators, and assigns, to their own use and behoof forever.

And I hereby covenant with the grantee that I am the lawful owner of the said animals; that they are free from encumbrance except as herein stated.........; that I have good right to sell the same as aforesaid; and that I will warrant and defend the same as against the lawful claims and demands of all persons.

In witness whereof $I$, the said........., hereunto set my hand and seal, this, the....... day of ......., 19..., in the....... of ......., county of........, and state of.........

(Signed) 
A defendant who sold a horse, giving false pedigree, showed that he could not read, and he believed that the pedigree made out by others was true. The horse had passed through several hands, and there were many horses of that pedigree in the neighborhood. A verdict was returned that he was not guilty of fraud. ${ }^{52}$ The Revised Statutes of Maine prohibited the sale of animals infected with tuberculosis. A sold oxen to B, taking B's note therefor. The oxen died of tuberculosis. A sued for the collection of the note, but the court held that he could not recover if the cattle were infected when they were sold. ${ }^{53}$

An executory contract for the future delivery of cattle of which the seller is not then the owner is not void as a wagering of contract, where the parties intend an actual delivery and acceptance. ${ }^{54}$

197. Ownership of Increase. According to the common law the ownership of the increase belongs to the owner of the mother, ${ }^{55}$ in the absence of contract or agreement to the contrary ${ }^{56}$ (except in the case of swans, etc.). Thus, in the replevin of a mare and three colts, the ownership of the mare was held to carry with it the ownership of the colts which were conceded to be her offspring. ${ }^{57}$ The fact that one paid taxes on the mare, and paid service fees, and expenses of rearing her colts,

52 People v. Umlauf, 88 Mich. 274,50 N. W. 251.

53 Church v. Knowles, 101 Me. 264, 63 Atl. 1042.

54 Fletcher v. Jacob Dold Packing Co., 58 N. Y. S. 612; affirmed 169 N. Y. $571,61 \mathrm{~N}$. E. 1129 .
55 Stanfield v. Stiltz, 93 Ind. 249 ; Arkansas Val. L., etc., Co. v. Mann, 130 U. S. 69.

50 First Nat. Bank v. Eichmeier, 153 Iowa 154, 133 N. W. 454.

57 Dunning v. Crofutt, 81 Conn. 101, 70 Atl. 630 . 
with the consent of her owner, was held not to give him a title to the colts. The fact that one owned the mare when the colts were born was competent evidence for jury on an issue of ownership of the colts. ${ }^{58}$ This question would have been answered if the party caring for the mare had made a written contract with the owner. Where one hires a mare for use in breeding, the increase of the animal belongs to the hirer. ${ }^{59}$ The progeny of a mare which is the separate property of a wife is also her separate property; ${ }^{60}$ but the ownership of the mare by the wife should be capable of proof by documentary evidence, though not necessarily so.

Putting a mare in pasture in consideration of her services does not entitle the owner of the pasture to the increase. ${ }^{61}$ When stock is loaned the ownership of the increase is in the loaner. ${ }^{.2}$ But if the stock be hired for a definite period the ownership of the increase belongs to the usufructuary, ${ }^{63}$ for at that time he has an ownership in the dam. ${ }^{64}$ A colt born to a mortgaged mare is held also under the mortgage. ${ }^{65} \mathrm{~A}$ colt foaled after

58 Morse v. Patterson, 1 Kas. App. 577, 42 Pac. 255.

59 MeCarty v. Blevins, 13 Tenn. 195, 26 Am. Dec. 262. 60 Kelley v. Grundy, $20 \mathrm{Ky}$. L. 1081,45 S. W. 100 . 61 Allen v. Allen, 2 P. \& W. 166.

62 Orser v. Storms, 9 Cow. 687.

632 Kent 360.

64 Garth v. Everett, $16 \mathrm{Mo}$. 490; Stewart v. Ball, 33 Mo.
154; Putnam v. Wyley, 8 Johns. 432; Concklin v. Havens, 12 Johns. 314; Wood v. Ash, (Eng.) Owen 139; August Brandt \& Co. v. Verhagen, 152 N. W. 448.

65 Kellogg v. Loveley, 46 Mich. 131, 8 N. W. 699, 41 Am. R. 151; Stewart v. Ball, 33 Mo. 154; Sawyer v. Gerrish, 70 Me. 254, Am. Eng. Enc. of Law, 349 . 
a levy on the dam is also held on the levy. ${ }^{66}$

In an action brought for the conversion of an animal with foal, as by unauthorized sale, if the mare gives birth to the colt the fact must be brought to the knowledge of the jury, or there will be no future redress in the matter. ${ }^{67}$

The unborn colt may be the subject of a transfer of ownership. A promise to deliver the increase of animals is a good consideration for their use. ${ }^{68}$ An agreement for valuable consideration to deliver the first female colt of a certain mare was a valid sale, though the colt was not then in existence. ${ }^{69}$ Two persons, one the owner of the horse, and the other the owner of the mare, made a contract that a third party, an infant, should have the increase. This was held valid as against the claims of ownership through the mare. ${ }^{i 0} \mathrm{~A}$ told his minor son B that if he would take a mare belonging to $A$ to horse, and pay for the same, the colt should be his. It was held that B had ownership in the colt as against the creditors of $A .^{71}$ Where a mare is sold on conditions, the seller retains ownership in the colts until the fulfillment of the conditions. ${ }^{72}$

198. Proof of Ownership. A properly executed bill of sale is the best possible evidence of owner66 Talbot $\nabla$. Magee, $59 \mathrm{Mo}$. App. 347.

67 Garth v. Everett, $16 \mathrm{Mo}$. 490.

68 Putnam v. Wyley, 8 Johns. 432, 5 Am. Dec. 346.

69 Fonville v. Casey, 1 Murph. (N. C.) 389 .

7o MeCarty v. Blevins, 5 Yerg. (13 Tenn.) 195, 26 Am.
Dec. 262; Hull v. Hull, 48 Conn. 250, 40 Am. R. 165.

71 Linnendoll v. Doe, 14 Johns. 221.

72 Buckmaster v. Smith, 22 Vt. 203; Elmore v. Fitzpatrick, 56 Ala. 400; Faith v. State, 32 Tex. 373 ; Espy v. State, 32 Tex. 375 . 
ship. By a statute in Texas it was provided that for the sale of live stock running at large on a range a bill of sale was required, and possession without a bill of sale was considered as prima facie evidence of illegality. ${ }^{73}$ Such a law is not retroactive, as to cattle in possession before its enactment. ${ }^{74}$ The bill must be executed at the time of sale. and delivery. ${ }^{75}$ The statute is constitutional. ${ }^{75 a}$ But the presumption that possession is illegal may be rebutted by evidence that it is legal. ${ }^{76}$

199. Marks and Brands. A common method of designating ownership is by the use of brands or marks. This form of evidence is especially necessary where the animals are upon a range, where the herd of one stockman may become mixed with that of another. For this reason, especially in the westem states, it is quite customary that legislatures make special provisions governing the use of brands.

For greatest value, and for the protection of the person making the brand, it is necessary that the mark be recorded; and statutes so provide. The brand should be recorded in the county where the stock runs, but it need not be recorded in every county in which they run. ${ }^{77}$ It may be recorded in as many counties as the owner may wish, ${ }^{\text {is }}$

73 Black v. Vaughan, 70 Tex. 47,7 S. W. 604.

74 Espy v. State, 32 Tex. 375.

75 Houston v. State, 13 Tex. App. 595.

75a Faith v. State, 32 Tex. 373.

76 Black v. Vaughan, 70 Tex.
47,7 S. W. 604 ; Wells v. Littlefield, 59 Tex. 556; Florey $v$. State, 13 Tex. App. 665.

77 Thompson r. State, „6 Tex. App. 466.

is Atterberry v. State, 19 Tex. App. 401. 
and it is wise to record in each county in which the stock are likely to be found in large numbers. Where the statute provides that no brand shall be recorded unless the record also states the part of the animal branded, it was held that a record of a brand "on the shoulder or side" was prohibited. $^{79}$ In other words, the brand should always be placed upon the same part of the animal, and the place selected should be one which is convenient for identification with the least trouble. Unless the statute requires that the kind of animal upon which the brand is used be recorded, that need not be stated. ${ }^{80}$ It has sometimes been a practice that the stock owner have one brand for his cattle, and another for his horses. This practice is objectionable.

An unrecorded mark may be an evidence of ownership, ${ }^{81}$ and it may be used as an evidence of the identity of an animal. ${ }^{82}$ A statute providing that a party shall have but one mark does not prohibit the owner from changing his mark." In Oregon it was held that the record of a brand of stock in the office of the clerk of the county court is not constructive evidence that an animal so branded belong's to the owner of the brand. ${ }^{84}$ On the other hand, in Texas it was held that a registered cattle brand is prima facie proof of

79 Reese $\nabla$. State, 43 Tex. Cr. 539,67 S. W. 325.

80 Ledbetter v. State, 35

Tex. Crim. 195, 32 S. W. 903.

81 Dixon v. State, 19 Tex.

134; Love $\nabla$. State, 15 Tex. App. 563.

\&2 Brooke r. People, $23 \mathrm{Col}$.
375, 48 Pac. 502; State v. Cardelli, 19 Nev. 319, 10 Pac. 433 ; Poage r. State, 43 Tex. 454. 83 MeClure v. Sheek, 68 Tex. 426,4 S. W. 552.

84 Stewart v. Hunter, 16 Ore. 62, 16 Pac. $876,8 \mathrm{Am}$. St. R. 267. 
ownership of cattle so branded. ${ }^{85}$ It was also held that a mark or brand constitutes of itself no evidence of ownership unless the mark or brand has been recorded. ${ }^{86}$ A statute making a recorded brand evidence of ownership does not exclude other evidence to show ownership. ${ }^{87}$

A judgment foreclosing a mortgage on cattle which were designated by brands given in the mortgage will not be set aside on the ground that the mortgage did not cover the increase, in the absence of evidence that the increase of the cattle were branded with the brands descriptive of the stock covered in the mortgage. ${ }^{88}$ Where the defendant, in replevin for horses, relies solely on a certain brand on horses as evidence of ownership, evidence of the sale of horses so branded to the defendant is incompetent without proof that such brand has been recorded by the grantor. ${ }^{89}$

200. Sale of Brand. Where the law permits an assignment of brand, but does not specify how, it is proper to admit parole evidence of such assignment made before the passage of the law requiring recording: ${ }^{90}$ Under a contract whereby defendant sold his brand to plaintiff, defendant to have his horses on the range, plaintiff to be the

85 De Garca v. Galvin, 55 Tex. 53; Beyman v. Black, 47 Tex. 558.

86 Herber v. State, 7 Tex. 69 ; Poag v. State, 40 Tex. 151; Corn v. State, 41 Tex. 301; Allen v. State, 42 Tex. 517; Elsner v. State, 22 Tex. App. 687, 3 S. W. 474 ; State v. Cardelli, 19 Nev. 319, 10 Pac. 433.

87 Love v. State, 15 Tex. App.
563; Hutton v. State, 7 Tex. Cr. App. 44; State r. Cardelli, 19 Nev. 319, 10 Pac. 433; Johnson v. State, 1 Tex. App. 333. 88 Edwards v. Osman, 84 Tex. 656, 19 S. W. 868 . 89 Murray v. Trinidad Nat. Bank, 5 Col. 359, 38 Pac. 615. 90 Chestnut v. People, $21 \mathrm{Col}$. 512, 42 Pac. 656. 
judge, plaintiff could not arbitrarily determine that an animal belonging to defendant was not his. ${ }^{91}$

201. Altering of Brand. Anything which makes proof of property more difficult is considered as altering a brand. ${ }^{92}$ The offense may be committed by merely clipping the hair at the original brand. ${ }^{93}$ Putting on a new brand is altering a brand. ${ }^{94}$

Altering a brand is not a felony unless it is clone with intent to steal, or convert the animal to the use of the person so doing it. ${ }^{95}$

In Texas, as a further protection to stock omners, it is provided that if a butcher kills unmarked cattle for market, or purchases and kills any animal without a written transfer from the vendor he shall be fined. Under this statute it was held that a butcher who slaughtered two unmarked cattle for a stranger, and then bought and sold them, was properly convicted. ${ }^{96}$ The statute also provides for the reporting of cattle slaughtered to the county conmissioners' court. A butcher cannot excuse himself for failure to report to the county commissioners' court at each term the number and description of the animals slaughtered by him, by producing a report for said term, sworn to and filed at a later term. ${ }^{97}$

91 Belknap v. Belknap, 20 S.

Dak. 482, 107 N. W. 692.

92 State $\nabla$. Davis, 24 N. C. 153.

93 Slaughter v. State, 7 Tex. App. 123.

94 Atzroth v. State, $10 \mathrm{Fla}$. 207; Linney v. State, 6 Tex. 1, $55 \mathrm{Am}$. Dec. 756 .
95 State v. Matthews, 20 Mo. 55.

96 Hunt r. State, 33 Tex. Crim. 93, 25 S. W. 127.

97 Bruns r. State, 33 Tex. Cr. 415, 26 S. W. 722. 
202. Wrongful Branding. Intent to defraud is an essential ingredient of the offense of illegally marking and branding an animal. ${ }^{98}$ The unlawful branding of a colt, the ownership of which is unknown, is an indictable offense.99 But, where the defendant, as soon as he discovered that he had branded a colt which did not belong to him, went to the owner and explained the circumstances, and bought and paid for the colt, he was not liable to indictment for wrongfully branding. ${ }^{1}$

203. Driving from Range. The Colorado act relative to the driving away of cattle, making the same larceny, is not intended to take it out of the general act, but to make it indictable under either. ${ }^{2}$ The act will not be pronounced felonious where, in good faith, the animal appears to have no owner. ${ }^{3}$ To recover for the unlawful driving away of cattle it is necessary to prove some knowledge on the part of the defendant that the domestic animal of another had entered his herd. ${ }^{4}$ Under the Texas Penal Code an offense is complete as soon as the cattle are driven across the county line, and may be prosecuted in either county. ${ }^{5}$ "Wilfully" means with evil intent. ${ }^{6}$ But one in charge of pasture is not guilty of "wilfully driving cattle not his own from their accustomed range," for driving away from pasture cattle

98 Fossett v. State, 11 Tex. App. 40.

99 State v. Haws, 41 Tex. 161.

1 Taylor v. State, 35 Tex. 496.

2 Kollenberger v. People, 9 Col. 233, 11 Pac. 101.

3 State v. Swayze, 11 Ore. 357, 3 Pac. 574.

\footnotetext{
* Chamberlain r. Gage, 20 Iowa, 303.

5 Rogers r. State, 9 Tex. App 43.

- Yoakum v. State, 21 Tex. App. 260, 17 S. W. 254.
} 
turned in without permission. ${ }^{7}$ Neither is one guilty for turning horses out, especially when he notifies the owner. ${ }^{8}$

204. Breeding. There are many legal questions which may arise relative to the breeding of stock. Some of them depend upon statutory enactment, and others arise through the application of the common law. Under the old Kentucky statute which prohibited the standing of a stallion or jack without a license, it was held that a person not the owner was properly convicted. ${ }^{9}$ Under a contract that he might have mules for less than value, a conviction was sustained for standing without license. ${ }^{10}$

205. Service Fees. An act providing for publication by the owner of a stallion of terms for service does not prohibit a contract for different terms. ${ }^{11}$ In Maine it was held that the price of service of a stallion which has not been registered may be recovered when the animal has not been advertised or held ont for public use. ${ }^{12}$ In a later case it was held that the owner of a stallion could not recover when he failed to file the pedigree as required by statute. ${ }^{13}$ There is no recovery for the services of an unlicensed stallion in Kentucky. ${ }^{14}$ Under a contract for the services of a

7 Wells v. State, 13 S. W. 889, Tex.

8 Mahle v. State, 13 S. W. 999, Tex.

9 Commonwealth v. Brandon, $43 \mathrm{Ky} .2$.

10 Commonwealth v. Harris, $47 \mathrm{Ky} .373$.

11 Sturgeon v. Merritt, 49 Mo. App. 160.
12 Briggs v. Hunton, $87 \mathrm{Mf}$. 145, 32 Atl. 794, 47 Am. St. R. 318.

13 Davis v. Randall, $97 \mathrm{Me}$. 36, 53 Atl. 835 .

14 Smith v. Robertson, 106 Ky. 472, 50 S. W. 852, $20 \mathrm{Ky}$. Law, 1959,45 L. R. A. 510. 
jack to continue until July, the owner of the jack to receive five dollars for each colt, or pay at the rate of twenty dollars a month, when the contract was cancelled by agreement in May it was held that on the failure of the plaintiff to elect the method of payment the defendant might do so. ${ }^{15}$ A contract to pay fifty dollars for the colts of five mares to be put to a jack, colts or no colts, was held not payable until the usual weaning time of the colts, unless there be express agreements to the contrary. ${ }^{16}$

206. Warranty of Sound Heredity. Although it was stated in one case ${ }^{17}$ that there is no implied warranty in the contract for the services of a stallion that the animal is free from disease which may be transmitted to offspring, this general conclusion should not be drawn from the case in question. So far as is known today in science, the transmission of disease directly from father to child is extremely improbable. The father may, by direct contact, communicate a disease to the mother; and similarly the mother may communicate it to the child; but these are cases of contagion, not of heredity. But by heredity parents do become reproduced as to structure in the offspring. Certain structural forms predispose the animal to definite reaknesses. Thus, with certain conformation of the limbs an animal is predisposed toward the development of a spavin, whenever the joint is put upon strain. The colt inherits

15 Conwell v. Smith, 8 Ind. 530 .

17 Briggs v. Hunton, $87 \mathrm{Me}$. 145, 32 Atl. 794.

16 Brown v. Mattingly, $42 \mathrm{Ky}$. 592. 
the structural form of joint predisposing to the spavin, but does not inherit the spavin. The form of joint is apparent to any horseman who inspects the animal. It is possible that the stallion might beget many colts without having one which developed a spavin. The form of the animal is one of the points which the owner of a mare must consider in making a selection of a sire for his colts. On the other hand, owners of stock who knowingly expose other animals to a danger of disease contracted from their stock are, and should be, held liable for the damage thus caused. (\$211.) A horse afflicted with dourine might transmit the disease to the mare, and from her it might infect the colt, causing its intrauterine death. A stallion, being kept for special purposes, and under special conditions, should not be classed with animals in general. It seems to us that the owner may reasonably be charged with a higher degree of care than animal owners generally, to insure the healthfulness of his horse; and if he be negligent, he should be held liable.

207. Insurance of Get. By contract the service fee was due at the time of service, with the privilege of next season in case of failure. Before the next season the horse died, but the court held that the owner was entitled to the fee; ${ }^{18}$ but the contrary decision was given in a Maine case. ${ }^{19}$ In a case of contract for service, insured, the mare was sold, not with foal. It was held that the fee was 42.

18 Price v. Pepper, $76 \mathrm{Ky}$.

10 Pinkham v. Libhy, 93 Me.
575,45 Atl. 823,49 L. R. A. 693. 
collectable. ${ }^{20}$ Where the contract for the service of a jack called for the purchase of a mule colt for ten dollars; otherwise the owner was to receive nothing, it was held that there was no insurance. ${ }^{21}$

208. Liens for Service. A lien on the mare or her colt, or both, may be established by statute or by contract, for the payment of service fees; and a similar lien is recognized in the common law so long as the mare remains with the owner of the stallion. $^{22}$ A's mare was served by B's stallion, whereupon $A$ agreed in writing to pay $B$ twenty dollars, twelve months from date, if his mare proved with foal, "colt holden for payment." It was held that this was a contract in the nature of a mortgage attached to the colt when born. ${ }^{23}$

The lien for the service of a stallion, provided by the New York statute of 1887, exists from time of service, and one who purchases a mare after selvice, but before filing of the notice of lien, and before expiration of time, takes her subject to the existing lien. ${ }^{24}$ So, also, in Tennessee it was held that the lien established by the law of 1879 is paramount to the right of a mortgage of a mare while in foal, although the mortgage was registered before the foal was dropped. ${ }^{25}$ A judgment mnder the statutory lien, where the mare is sold, applies not on the new owner, but as a lien on

20 Pitcheock v. Domnahoo, 70 Ark. 68, 66 S. W. 145.

21 Aubuchon v. Pohlman, 1 Mo. App. 298.

22 Scarfe v. Morgan, 4 M. \& W. 270; Grinnell v. Cook, 3 Hill 485, 38 Am. Dec. 663; Jackson v. Holland, 31 Ga. 339.
23 Sawyer v. Gerrish, $70 \mathrm{Me}$ 254, 35 Am. Rep. 323.

24 Tuttle $v$. Dennis, 58 Hun, 35,11 N. Y. Sup. 600.

25 Sims v. Bradford, 80 Tenn. 434. 
the colt. ${ }^{26}$ A contrary view was expressed in an Arkansas case. ${ }^{27}$

209. Liability of Owner of Stallion. The owner of a stallion is liable for injuries to a mare while being served, due to the negligence of such owner. ${ }^{2 s}$ Wrong entry is evidence of negligence. ${ }^{29}$

210. Gelding a Stallion. Where a stallion was not kept for breeding purposes as provided by the code, or defendants did not have knowledge of such fact, and they found him running at large out of the enclosed grounds of the owner in any month from March to November, they had the right under the Oregon statute to geld him, without first taking the animal to the owner twice. ${ }^{30}$ One C. A. L. Loomis had a colt running in the pasture of W. H. Loomis, with other horses, among which was a valuable standard bred stallion colt belonging to W. H. Loomis. C. A. L. lived in town. He engaged a veterinarian to geld his colt, but said that his son would take the veterinarian to the pasture and show him the colt. Whereupon the veterinarian found the boy and told him that he was to geld "Loomis's colt." The boy misunderstood, and assisted in catching the colt of W. H. which was then operated upon. The veterinarian was held for damages, and the measure of damages was to be the value of the colt immedi-

26 Harby v. Wells, 52 S. C. 156,29 S. E. 563.

27 Easter v. Goyne, 51 Ark. 222.

28 Cavender v. Fair, 40 Kas. 182, 19 Pac. 638.

29 Medsker v. Pogue, 1 Ind.
App. 197, 27 N. E. 432 ; Scott v. Hogan, 72 Iowa, 614, $34 \mathrm{~N}$. W. 444; Peer v. Ryan, 54 Mich. 224, 19 N. W. 961.

30 Tucker v. Constable, 16 Ore. 407, 19 Pac. 13. 
ately after castration deducted from the value immediately before the operation. ${ }^{31}$

211. Liability of Owners of Animals. Where the statutes do not prohibit, the owner of infected animals may pasture them upon his own land, ${ }^{32}$ but he must use due care to prevent the spread of infection. $^{33}$ If, through the negligence of the owner or his servants, the infection spreads to other animals the owner will be held liable for the injury done. ${ }^{34}$ Infected animals must not be watered at a public trough. ${ }^{35}$ The bringing of a glandered horse into a public place is a common law offense. ${ }^{36}$ The owner of animals agisted is liable for any harm which may be caused by them, ${ }^{37}$ though the agister may be liable to the owners of other animals which may be injured through the agency of the infected or vicious stock. ${ }^{38}$

The owner is liable for injury inflicted by a vicious animal, provided that he had previous knowledge of the animal's character, and had not taken due care to prevent accident. ${ }^{39}$ The knowl-

31 Loomis v. Beese, 148 Wis. 647,135 N. W. 123.

32 Fisher v. Clark, 41 Barb. 329.

33 Mills v. N. Y. etc. Ry. Co., 2 Rob. (N. Y.) 326; Clarendon I,and, etc. Co. v. McClelland, 89 Tex. 483,34 S. W. 98,35 S. W. 474.

34 Herrick v. Gary, 83 Ill. 85; Grayson v. Lynch, 163 U. S. 468; Mesa de Mayo L. \& L. S. Co. v. Hoyt, 24 Colo. App. 279 , 133 Pac. 471.
35 Mills v. N. Y. etc. Ry. Co.,

2 Rob. 346.

36 Reg. v. Henson, 1 Dears, 24.

37 Sheridan v. Bean, 8 Mete. 284.

38 Schroeder v. Faires, 49 MIo. 470; Costello v. Van Eyck, 86 Mich. 348,49 N. W. 152 ; Haltey v. Markel, 44 Ill. 225.

39 Nayer $\nabla$. Kloepfer, 69 Atl. 182 ; Robbins v. Magoon \& Kimball Co., 153 N. W. 13. 
edge of the teamster and barnman that the mule was vicious was sufficient to charge the owner with legally knowing the fact in a case where a servant was killed by the kick of a mule, and the owner was held liable. ${ }^{40}$ A person violating the public statutes enacted for the protection of individuals is liable for any injury resulting proximately therefrom. ${ }^{41}$ So where the defendant allowed his horses to trespass on plaintiff's land, and one of the plaintiff's animals playing with them at a fence was injured, it was held that the defendant's negligence was the proximate cause of the injury. ${ }^{42}$ An owner is liable for the damage done by his animals when he drives them upon the land of another. ${ }^{43}$ Where one landholder has waived the duty of a neighbor from keeping up a fence he is estopped, in a claim for damages. from denying his own duty to keep up his cattle. ${ }^{44}$

The keeper of domestic animals is only bound to use reasonable care to prevent injury being done by them. If the animal is rightfully in the place where the injury is done, there is no liability, unless the animal is vicious, and the owner knew it. There could be no recovery for the bite of a dog if the person be bitten as result of his own negligence, or misconduct. Where a horse attached to a wagon jumped onto a sidewalk and bit the plaintiff, the plaintiff is not excused from proving viciousness simply because the horse had

40 Robbins v. Magoon \& Kimball Co., 153 N. W. 13.

41 Schaar v. Comforth (Minn.), 151 N. W. 275.

42 Houska v. Hrabe (S.

Dak.), 151 N. W. 1021 .
43 Angus Cattle Co. v. MeLeod, 152 N. W. 322.

44 Milligan v. Wehinger, 68 Pa. St. 235. 
no right to be on the sidewalk.45 But evidence that a dog had previously bitten a person is inadmissible unless the claim be made that the dog is vicious. ${ }^{46}$

Plaintiff rented a barn to a construction company for the accommodation of horses injured, or sick on the job. One horse so housed was afflicterl with glanders, and the authorities ordered the destruction of the barn. Plaintiff sued the company for the loss of the barn; but it was held that in the absence of evidence of previous knowledge by the company that the horse had that disease, their act did not constitute a trespass, and the defendant company was not liable for the loss of the barn. ${ }^{47}$

212. Obligation to Restrain Animals. In order to get a clear idea of the relative rights of land holders and the owners of animals it is necessary to remember two fundamental common law principles. It is the duty of the owner of animals, and this is included in the basis of his ownership, to restrain his own animals. That means ordinarily that he must keep them within his own property by means of fences, or by tethering; and that when taken upon priblic land they should be under such general control as ordinary care would demand.

Secondly; the public highway is for the use of the public generally, not only for the passage of

45 Dix v. Sommerset Coal Co., \& Co., 72 Wash. 482, 130 Pac. 217 Mass. 146, 104 N. E. $433 . \quad 753,44$ I. R. A. (N. S.) 1092.

46 Keybolte v. Buffon (Ohio), Affirmed on rehearing, 72 Wash. 105 N. E. 192.

47 Farrar v. Andrew Peterson 482, 133 Pac. 594, 44 L. R. A. (N. S.) 1094 . 
persons from place to place, but also for such traffic as commercial conditions may require. It is therefore presumed that from time to time cattle of various kinds and sizes may be driven from place to place along the highway. The road is therefore public property, and to be used by individuals for the common good. The owner of adjacent land has no special rights in the road which runs by his place. The highway is for purposes of going, not for uses purely local. While the tethering of animals along the side of the road for grazing purposes might be ignored, still such use of the public land is essentially a trespass, and the owner would be held liable for any damage which might result; such, for example, as the frightening of a horse, causing a runaway, with the possible death of the driver; or, the tripping and injury of a horse passing properly along the road, by a rope fastened on one side of the track to a post or stake, and with a cow attached to the other end.

In general, therefore, it is the duty of every owner of animals to fence his own land so that his own animals will be restrained from wandering; and it is the duty of every land owner to protect his property by proper fences against the possible inroads of animals properly passing in the public highway. This means that the fences along: the highway are to keep animals either in or out, while those away from the highway are to keep the animals in. Cattle or sheep confined within a pasture have abundant time and opportunity for finding any possible weak place in the fence. This means that a pasture fence must be very 
much stronger than that dividing two meadows. On the other hand, animals simply driven along the highway have neither time nor opportunity for discovering any but very apparent weaknesses in the enclosing structure.

These general rules must often be altered to suit the locality or other conditions. Where cattle are permitted legally to wander upon the range, clearly every man must protect his own grain by fences. By agreement it is customary for the owners of adjacent property to unite in building line fences, or to agree that one shall keep up a certain portion, and the other another portion. This agreement should include a statement of the purposes for which it is erected. A fence which is entirely sufficient as a line fence would be improper for the restraint of animals; and a fence which would be good for horses would not restrain hogs, or if built for hogs it might not restrain cattle or horses.

A man is liable for the trespass of his animals through that portion of the line fence which it is his duty to keep up, without regard to the character of his neighbor's portion. ${ }^{48}$ But, an owner of property cannot recover for trespass when the trespass was due to his own negligence, as in a failure to keep his portion of the fence in repair. ${ }^{49}$

"Every unwarrantable entry by a person or his cattle on the land of another is a trespass, and a person is equally answerable for the trespass of his cattle as of himself." "50 Where cattle

48 Cooley, Torts, 399.

49 Carpenter v. Cook, $67 \mathrm{Vt}$. 102, 30 Atl. 998; Weide v. Thiel, 9 Ill. App. 223; Cowles v. Balzer, 47 Barb. 562; Duf-

fees v. Judd, 48 lowa, 256. $50 \mathrm{Am}$. \& Eng. Enc. of Law (2nd Ed.), 345. 
simply cross the land of another it is a trespass. ${ }^{51}$

It is a general rule that whoever may be in possession or control of animals is liable for their trespass, whether his possession be that of owner, hirer, agister, or bailee of any kind. But if an owner entrust his animals to an incompetent agister, he may be held liable on that account. ${ }^{52}$

213. Barbed Wire Fences. It must be remembered in reading decisions relative to barbed wire fences that they are of relatively recent use only. Secondly, there is a difference between a fence constructed of a few strands of the barbed wire, and one which carries with it a sufficient body to attract attention, such as a rail, or several strands together, at the top. One has no right to erect a barbed wire fence along a public highway in such a manner as to make probable injury to either persons or animals properly upon the highway. ${ }^{53}$ But the owner of the fence may not be held liable for injury to animals illegally roaming at large, ${ }^{54}$ nor where the injury was due to the contributory negligence of the owner of the animal, as where a man exercising a horse gave him so much rope that the animal ran against the barbed wire fence. ${ }^{55}$ In a Canadian case it was even held that the owner of the fence, which had no rail to give warning, was

51 Sturtevant v. Merrill, 33 Ne. 62 .

52 Ward v. Brown, 64 Ill. 307 ; Rosswell v. Cottom, $31 \mathrm{~Pa}$. St. 525; Wales v. Ford, 8 N. J. L. 267 .

s3 Elgin Road Trustees $\nabla$. Innes, 14 Rettie (Sc. Ct. Sess.) 48; Hurd v. Lacy, 93 Ala. 427;
Sisk จ. Crump, 112 Ind. 504; Foster v. Swope, 41 Mo. App. 137.

54 Galreston Land \& Imp. Co. v. Pracker, 3 Tex. Civ. App. 261, 22 S. W. 830.

55 Hoag $v$. Orange Mt. Land Co., 12 N. J. L. Jour. 243. 
not liable for the death of a colt playing by the side of its mother which was being led along the road, though the death came from the cuts inflicted by the barbs. ${ }^{56}$ Where a railroad company erected a barbed wire fence between its property and adjacent land, it was held liable for the death of sheep occasioned by the fence. ${ }^{5 \tau}$

214. Frightening Animals. The question as to the right of action against one for frightening animals is one which has resulted in an immense mass of litigation. It seems to us that it is one which must be settled largely by the special case. An automobile may properly be upon the public road, and a horse may be frightened thereby, but if the horse chances to be unusually nervous the autoist would not be liable. On the other hand, an autoist running at a high rate of speed by a horse should be held strictly liable for any damage which may result. A piece of paper accidentally blown out of a vehicle, thus frightening a passing horse, might not imply liability, while if thrown carelessly before a horse which is frightened thereby, it would probably be considered as a creation of liability.

\section{Liability for Injuries on the Public High-} way. A distinction must be made between streets and bridges which are under the control of municipalities, and those which are simply public property. Where an animal passing along a public highway is injured as a result of some defect in the road, or obstruction there placed, the person

56 Hillyard v. Grand Trunk Ry. Co., 8 Ont. 583.

57 Siglin v. Coos Bay, R. \&
E. R. \& N. Co., 35 Ore. 79,56

Pac. 1011. 
responsible for the obstruction or defect may be held liable individually, whether he hold a public office or not; but the state cannot be sued, and there is no liability on the part of the county or township which is unincorporated. ${ }^{58}$ In a city the corporation may be held liable, though not necessarily so. ${ }^{59}$

58 Public Health, 357.

59 Public Health. 358. 


\section{CHAPTER X.}

\section{BAILMENT.}

\$220. Definition.

§ 221. Bailment a Contract.

$\S 222$. Bailer May Not Be Owner.

$\S 223$. Bailment Implies Knowledge of the Bailee.

$\$ 224$. Care Required of Bailee. $\$ 225$. Ordinary Care.

$\S 226$. Duty of Bailor.

$\S 227$. Liability of Bailee.

$\S 228$. Warranty of Bailor.

$\S 229$. Bailment, Sale, or Gift. $\S 230$. Bailee's Right to Use Property Bailed.
$\S 231$. Actions for Liability of Bailee.

§ 232. Conversion.

$\$ 233$. Liens.

$\S 234$. General Liens.

$\S 235$. Agister's Lien.

$\S 236$. Trainer's Lien.

$\S 237$. Priority of Right.

$\S 238$. Right of Sale.

$\S 239$. Estrays and Trespassing Animals.

$\S 240$. Waiver of Lien.

\$ 241. Illegal Sale by Bailee.

§ 242. Lien Once Lost Can Not Be Revived.

220. Definition. The term "bailment" is held to include that large variety of cases in which the personal property of one person is left temporarily in the charge of another. The law of bailment is therefore involved in a large proportion of the cases arising in disputes over the handling and care of animals. The livery man is a bailor when he rents out one of his teams; and he is a bailee when he takes the horse of another to feed. The veterinarian is a bailee when he assumes the care of an animal sick either on the owner's premises, or in the veterinary hospital. The owner of a pasture is a bailee when he takes the stock of a neighbor to agist, and the blacksmith is a bailee when he shoes an animal. The owner of a stallion 
is a bailee of mares brought to his stallion, so long as they are in his care. The butcher is the bailee of cattle which he slaughters for another, and the man who distrains cattle found trespassing upon his property, or who impounds stray animals, is a bailee. (See § 79.)

221. Bailment a Contract. Every act of bailment is under a contract, implied or expressed. If the exact terms are not fixed beforehand they must be determined by common or statutory law. There is always this one point found in bailment, namely, that the bailee agrees to return the article bailed upon the proper demand of the bailor. In the bailment of animals it is further agreed that the bailee must feed and care for the stock surrendered to his care, and that he shall use due diligence to see that they are not injured in any way. Clearly, if the stock do not need feeding while he has them in charge, he cannot be expected to do so. The man hiring a livery team for a couple of hours would not be expected to feed them in that time, but if he kept them for the entire day he would be negligent were he to neglect to give them food and water.

222. Bailor May Not Be Owner. The bailor need not, necessarily, be the owner of the thing bailed. He may himself be a bailee to whom the owner has entrusted the animal, as a servant may be sent with a horse to the smithy; or the bailor may have stolen the animal. In the case of a servant, acting for his employer, the employer may be recognized as the real bailor. It is the duty of the bailee to deliver the animals bailed to the bailor, and if he should deliver to any one else he may be 
held liable for whatever may happen until the animals are recovered.

223. Bailment Implies Knowledge of the Bailee. "An example used by many of the authors on this subject is where one, by mistake, puts his purchased articles into another's wagon in the street, and the owner, without any knowledge of their presence, drives away with them. So long as he is ignorant of having them in his possession he is under no obligation to care for them; he may lose them by the grossest carelessness upon his part, and he is not liable because he is not in any sense a bailee; but the moment he discovers the parcels, and has knowledge of the fact that he has them in his possession, from that moment he becomes a bailee, and is legally bound to care for them, and if lost, under certain circumstances would be liable to the owner." 1 So the owner of property upon which animals have wandered is not a bailee so long as he is ignorant of their presence; but if, after he knows of their presence, and while they are still upon his place, they should be injured through any act, or negligence on his part, he may be held liable to the owner for injury suffered.

224. Care Required of Bailee. The degree of care demanded of the bailee in the discharge of his obligation varies greatly according to circumstances. The decision of the question depends, first, upon the terms of the bailment. Manifestly, when the animals bailed are being kept free for the interest of the bailor the degree of care which

1 Van Zile, Bailments and Carriers, 18. 
should be demanded would be less than where the animals were loaned for the use of the bailee, free of charge. Midway between these would be the case in which the animals are hired out for the mutual benefit of both; the bailee gets the use of the animals, and the bailor receives pay for their service. Where an animal is loaned free for the use of the bailee, the liighest degree of care and diligence to insure the safe return will be demanded of the bailee in law, and if injury results because of his slight negligence he will be held strictly to account therefor. ${ }^{2}$ But when as an accommodation to the owner a man assumes the care of his stock, and expects nothing in return for his labor, and perhaps pasture, the law will presume only the exercise of a slight degree of diligence, and will hold him for damages only when they are the result of his gross carelessness or negligence. ${ }^{3}$ When the bailee either hires the use of the animals, or takes the animals to care for, the court will only expect him to use such ordinary care as he would were they his own; and will hold him responsible only for ordinary negligence.

A man driving along an open country road might permit the horse to take his own way much of the time without being negligent; but the same horse must be driven with a guiding rein through a crowded city street. A sound horse may be driven with less guidance than one which is known

2 Howard v. Babcock, 21 Ill. 259 ; Robertson v. Brown, 1 U. C. Q. B. 345 .

3 Line v. Mills, 12 Ind. App. 100,39 N. E. 870 ; Thompson v. Harlow, 31 Ga. 348; Bass v. Cantor, 123 Ind. 444, 24 N. E. 147; Wolseheid v. Thome, 76 Mich. 265, 43 N. W. 12. 
to be blind, or lame, or vicious, without lessening the degree of diligence.

225. Ordinary Care. Ordinary care means that amount of diligence which one would exercise with regard to his own like property. There can be no hard and fast rule in this regard. For example, horses accustomed to be kept in barns, if they chanced to be in a pasture when a storm came up, with sleet and snow, would suffer if left exposed. Ordinary care would mean the bringing of the horses to shelter; but ordinary care for a lot of wild horses, accustomed to exposure during winter, in the same storm would mean letting them alone.

A milch cow would be injured were she not milked at the usual time, and ordinary care requires that she be milked for her own safety. Sheep permitted to wear their winter coat of wool through the summer months would suffer, and ordinary care demands that such sheep be sheared; but if the sheep are being boarded, or agisted, in the absence of special agreement the wool would be the property of the owner of the sheep. The care of the sheep includes also the care of the wool, and if it cannot be preserved without loss to the owner, ordinary care would mean that the wool must be sold, and in the place of handing over the wool itself the agister would pass over the money received.

226. Duty of Bailor. "It is the duty of the bailor to exercise good faith toward the bailee by giving him notice of all the faults of the thing bailed, within his knowledge, that might result in exposing the bailee to danger, and if he fails to do 
so, and by reason of it the bailee is injured, the bailor will be liable. As, for example, if the bailor should loan a vicious horse, it is his duty to notify the bailee of the fact, and if by reason of the bailor's failing to give such notice the bailee should be injured, he may recover damages of the bailor." 4

If a livery man hires out a horse accustomed to run away, and fails to notify the person hiring it, he will be liable for the full amount of damages which may result from such an act. But if, having been warned of this habit, the bailee fails to exercise care and diligence proportional to the warning given, and the horse runs away, the bailee may be held liable for all damage sustained, not only by the owner of the horse, but also by other persons.

227. Liability of Bailee. A man would not use his own horse if it were sick or lame. When a horse becomes sick or lame it is therefore the duty of the bailee to abstain from using it, and if he continues he is liable for any injury resulting. ${ }^{5}$

The bailee is not liable for injuries not caused by his abuse or negligence. ${ }^{6}$ If a hired horse is taken ill and the bailee calls a farrier he is not liable for the farrier's lack of skill, but he may be held liable for gross negligence if he be not careful in the selection of a competent veterinarian. ${ }^{7}$

Every contract of letting impliedly warrants

4 Van Zile, Bailments and Carriers, 22.

5 Hawkins v. Haynes, $71 \mathrm{Ga}$. 40; Leach v. French, 69 Me. 389, 31 Am. Rep. 296; Edwards v. Carr, 13 Gray (Mass.) 234.
6 Thompson v. Harlow, 31 Ga. 348; Perham v. Coney, 117 Mass. 102.

7 Dean v. Keate, 3 Campb. 4. 
that the animals are reasonably fit and suitable for the work which they are hired to perform, if the same is known to the bailor. ${ }^{8}$ It is thus his duty to notify of vicious propensities, and he is liable for the vicious act of his horse if he failed to give notice. ${ }^{9}$ But when the bailor wamed the bailee of the horse's habit of kicking, and the bailee did not use a kicking strap, it was held that the bailor was not liable for injury sustained. ${ }^{10}$

A distinction must be recognized between negligence and fraud or deceit. The bailor makes no implied warranty that his animals are fit to do more than that for which they are hired. If a man should engage a span of horses to drive for a forenoon, and should take a span of roadsters and hitch them to a plow for the breaking of land, a purpose for which they were not fitted, and were not hired, the bailee would be held strictly liable for the full amount of damage sustained by the team, for he practiced fraud and deception in the transaction. ${ }^{11}$ No superficial technicality of words would relieve him. Were he to plead that he engaged the horses for driving, but that he did not say where he was going to drive them, or hitched to what kind of a rig, and that therefore he had not used them for a purpose otherwise than they had been hired, such a plea would doubtless be held only to indicate the greater degree of frand

8 Bass v. Cantor, 123 Ind. 444, 24 N. E. 147; Leach v. French, 69 Me. 389; Harrington v. Snyder, 3 Barb. 380.

9 Campbell v. Page, 67 Barb. 113; Mayer v. Kloepfer, 69 Atl. 182; Robbins v. Magoon \&
Kimball Co., 153 N. W. 13; Kissan v. Jones, 56 Hun, 432. 10 Ohlweiler v. Lohmann, 82 Wis. 198,52 N. W. 172.

11 Lockwood v. Bull, 1 Cow. 322. 
and deceit. Also, if a horse be hired to drive to a certain place, or for a certain time, ${ }^{12}$ and the bailee should drive much further, or use it much longer, and in consequence the horse be injured, it would be held that in addition to negligence in the care of the animal the bailee had used fraud, and he would be held strictly liable for the full amount of damage resulting from his overuse. ${ }^{13}$

It is the duty of the owner of an animal hired out and returned in a sick or injured condition, or in a condition which results in sickness, to give such animal proper care. ${ }^{14}$ If the owner simply lets his animal die he cannot recover for the loss of the animal from the bailee through whose negligence or misfeasance the illness or injury occurred. The owner can recover for the injury, and for the necessary expense of treatment, but he cannot recover for the increased loss due to his own negligence. He should employ a veterinarian that the loss be as small as possible.

228. Warranty of Bailor. Impliedly the bailor warrants that the animal let is fit and suitable for the purpose for which it is let. This warranty is not absolute, but it implies that with ordinary diligence the owner could discover no reason why it might be not suitable. To hold the bailor liable for damage resulting from the letting out of a vicious horse it was held in a comparatively recent case in Massachusetts that it is necessary to show that the owner knew that the horse was vicious,

12 Coggs v. Bernard, 2 Ld. Raym. 909.

13 Homer v. Thwing, 3 Pick. 492; Malaney v. Taft, 60 Vt.
571; Stewart v. Davis, 31 Ark. 518.

14 Graves v. Moses, 13 Minn. 335. 
or that he might reasonably have known that fact. ${ }^{13}$

229. Bailment, Sale, or Gift. It is sometimes a question whether the transaction may be a bailment, sale, or gift. The distinction is this: In a bailment the ownership remains in the possession of the original owner, to whom the bailee must return the article bailed. The bailor may sell or mortgage his property, subject to certain possible liens held by the bailee. In a sale there is an exchange of ownership for a compensation. In the gift there is an exchange of ownership without compensation. In bailment the owner cannot give possession to a possible vendee until the termination of the bailment. If the bailment is indefinite as to time it may be terminated at the will of either bailor or bailee; ${ }^{16}$ but if it be for a given term it cannot be terminated before the time set, except by the agreement of both bailor and bailee. Thus, where sheep were let for one year the court beld that there was essentially a change of ownership, and that the payment for the sheep received was to be made in a like number of sheep of the same kind one year from the date they were received. ${ }^{17}$

Though the distinction between bailment, sale and gift seems simple in the abstract, in practical application it may not be so plain. Suppose a poor man should lose his cow, and his rich neighbor should tell him: "You may take one of my cows,"

15 Copeland v. Draper, 157 Mass. 588, 19 L. R. A. 283.

10 Learned Letcher Lumber Co. v. Fowler, 109 Ala. 169, 19 So. 396 .
17 Bellows v. Denison, 9 N. H. 293; Wilson v. Finney, 13 Johns. 358. 
would it be a gift, or a loan? The question could only be answered by coördinating facts. The letting of a flock of sheep for a year is a virtual sale. A yoke of oxen hired for a month is a bailment; the same oxen must be returned.

There are so many possible questions which may arise in the bailment of animals that for mutual protection the contract should be in writing, in the form of a contract, if the bailment is to continue for some time. The contractual form is always to be preferred, but for short terms a receipt, stating terms as understood, would be sufficient. (See $\S 80$.)

230. Bailee's Right to Use Property Bailed. The right of the bailee to make use of the property bailed must depend upon the exact terms of the agreement. Where the animals are hired out to the bailee, or where he is keeping them as an accommodation for the bailor, it is understood, in the absence of any special agreement to the contrary, that the bailee may use them as if they were his own. ${ }^{18}$ When the bailee is being paid for the care of the animals, in the absence of a supplementary agreement, it is understood that he is expected to give them ordinary care, and that he will not use them. Should he make use of them he may be held liable for damages. ${ }^{19}$ Such a ruling would probably not be made for the use of the milk of a milch cow, for proper care would require the milking, and the mill is not of a nature fit for preservation. However, if the contract calls for

18 Van Zile, Op. cit. 45.

19 Collins v. Bennett, $46 \mathrm{~N}$.

Y. 490; Van Zile, Op. cit. 46. 
the delivery of the milk to the owner, clearly all of the milk should be so delivered. A horse kept in a stable must be exercised to preserve its health, and if it be driven no more than is necessary for that purpose, even though the bailee drove it for use it would not ordinarily be considered a violation of his duty as bailee; but if the contract expressly forbade such driving he would be held liable. ${ }^{20}$

231. Actions for Liability of Bailee. Where the petition in action sought to recover for the loss of certain cattle put to pasture, through the carelessness and negligence of the agister, the burden of proof was held to be on the plaintiff. ${ }^{21}$ The hirer of a horse, to avoid liability for injury, was not bound to show how the injury was received; it being sufficient to show that it was mysteriously inflicted in the night, whereupon the owner was bound to show the hirer's negligence. ${ }^{22}$ Where a horse is let on contract providing that on a day's notice the horse shall be returned in same condition as received, compliance is excused by the death of the horse without fault of the bailee. ${ }^{23}$

Under a contract to pay the value of a mare if not returned in good condition, the acceptance of the mare does not constitute a rescission of contract, or waiver of right to recover her value."-4

20 Collins v. Bennett, $46 \mathrm{~N}$. Y. 490.

21 MeCarthy v. Wolfe, 40 Mo. 520 ; Rayl v. Kreilich, 74 Mo. App. 246; Casey v. Donovan, 65 Mo. App. 521.

22 Sanford v. Kimball, 106 Me. 355,76 Atl. 890 .
23 Am. Preservers' Co. v. Drescher, 4 Mise. (N. Y.) 4S , 24 N. Y. Sup. 361.

24 Austin v. Miller, 74 N. C. 274. 
Where the contract called for the return of sheep in good marketable condition, and it was shown that the sheep were diseased when bailed, it was held that the contract be understood to mean in as good marketable condition as could reasonably be expected..$^{25}$ Where the sheep were to be returned in the same condition as they were received, and they were returned pregnant, and began dropping their lambs in winter, and in consequence some died, it was held to be no breach of contract when it was shown that they were delivered to the bailee pregnant, and dropped lambs in January and February. ${ }^{26}$

In a contract to pay a dollar a day for the use of oxen, and feed and take care of them, it was held that payment must be made for the days worked, and that the feed and care must be given for the entire time until the oxen were returned. ${ }^{27}$

232. Conversion. It is an important and essential element in a contract of bailment that the bailee shall return the article bailed to the bailor upon proper demand. Any act of the bailee which shall interfere with such return is conversion. The bailee may wrongfully sell the animal; he may wilfully or negligently kill it or he may appropriate it to his own use unlawfully. Upon any of these events the bailor may terminate the bailment and make demands for the return. If the animal be sold he may recover possession, by replevin or otherwise, and let the innocent purchaser hunt for his satisfaction from the bailee.

25 Peck v. Brewer, 49 Ill. 54. 26 Williams v. Frazier, 41 How. Pr. (N. Y.) 428.
27 Learned Letcher Lumber Co. v. Fowler, 109 Ala. 169, 19 So. 396. 
A bailee, as bailee, could give no lawful title. ${ }^{28}$ Or the bailor may recover a fair market value for the articles converted, or if they be sold for a greater price he may recover all that has been received. It has been held, relative to horses that have been hired out for driving, that a willful and intentional deviation from the ordinary line of travel is an act of conversion,,$^{29}$ entitling the owner to recover therefor in addition to the ordinary hire. On the other hand, it has been held that if an animal did not receive his injury while being driven outside the limits of the hiring, the bailee could not be held for conversion. ${ }^{30}$

233. Liens. The keeping of many articles requires no expense, and but little care. The keeping of animals implies constant care and expense. It is therefore usual that the contract provide for compensation for the care and feeding of the animals. The compensation may be in the nature of use, as where the oxen are loaned to a neighbor; or where sheep are left with a bailee for their board, under the understanding that the agister is to have the increase and the wool. When it is provided that the bailor is to pay the bailee for the keep, it is frequently provided either by special contract or by statute that the bailee shall have a lien upon the stock for the payment due. Such a right has been sometimes recognized in the common law, but present usage is not favorable to

28 Lovejoy $\nabla$. Jones, 30 N. H. 164; Calhoon v. Thompson, 56 Ala. 166; Medlin v. Wilkinson, 81 Ala. 147; Johnson v. Miller, 16 Ohio, 431; Dunham v. Lee, 24 Vt. 432.
29 Spooner v. Manchester, 133 Mass. 270.

30 Farkas v. Powell, $86 \mathrm{Ga}$. 800 ; 12 L. R. A. 397 ; Rankin v. Shepherdson, 89 Ill. 445 . 
such construction. In addition, when the stock has been left for some special service, as that of a trainer, or of a veterinarian, a lien is frequently provided for the payment of those services. (§§ 79-83.)

A lien may be created by contract. ${ }^{31}$ A contract to pay before moving stock creates a lien. ${ }^{32}$ Where the contract for the keep of stock creates a lien, it operates on all; not upon a number proportional to the amount due. ${ }^{33} \mathrm{~A}$ contracted to care for the cattle of $B$ for five months; the contract was canceled in two months by B, who claimed that the cattle were not well kept. It was held by the court that A had a lien only for the payment of the care for the two months. ${ }^{34}$

234. General Liens. A specific lien is recognized in cases where the bailee has expended labor and material for the betterment of the thing bailed. The tailor has a lien on the clothes which he made from the cloth left by the bailor, etc. The lien of veterinarians, agisters, blacksmiths, and livery keepers has frequently been recognized either in common law or statutes. In each of these cases the lien attaches to the special item, or items in the possession of the bailee, for that specific account. General liens, that is the holding of any property for the payment of an account not related to the article directly, are not favored in law, and when found they are very strictly interpreted by

31 Cummings v. Harris, 3 vt. 244, 23 Am. Dec. 206.

32 MeCoy v. Hock, 37 Ia. 436. 33 Barse Live Stock Com. Co. จ. Adams, 2 Ind. Ter. 119, 48
S. W. 1023; Yearsley v. Gray, $140 \mathrm{~Pa}$. St. 238, 21 AtI. 31S; Hensel v. Noble, 95 Pa. St. 345. 34 Powers v. Botts, $58 \mathrm{Mo.}$ App. 1. 
the courts. ${ }^{35}$ They may be established by special contract, and sometimes possibly by statute, as where the innkeeper is given a lien on the baggage of his guest. But unless clearly authorized the bailee can have no lien except upon articles directly pertaining to the one matter. Thus, a veterinarian could have a lien upon the wagon of the bailor for payment of his veterinary bill only by special contract. A veterinarian could hold the horse in his possession for his bill in that case, and probably for his professional bill as a whole, but not for the use of his pasture by the sheep of the same owner, for that would be a separate account. "It is equally clear, on principle as well as authority, that where there is an entire contract for making or repairing several articles for a gross sum, the tradesman has a lien on any one or more of the articles in his possession, not only for their proportionate part of the sum agreed upon for repairing the whole, but for such amount as he may be entitled to for labor bestowed upon all the articles embraced in the contract." ${ }_{36}$ This same rule would apply, in the absence of specific contract, for the payment of "a reasonable amount" for services; and it should be interpreted to include a general account in the same line, as for the veterinarian's services. On the other hand, where separate contracts are made, as for the pasturage of a certain number of cattle at a given rate, and another for the feeding of a given number of hogs, it might be held that the lien on the hogs would not cover the account for the cattle. Fur-

35 Taggard v. Buckmore, 42 Ne. 77 .
36 Hensel v. Noble, $95 \mathrm{~Pa}$. St. 345 . 
ther, eren in the same matter, the lien might not cover the entire account, as where a lien is waived for accounts to a certain date. ( $\$ \S 82,240$.)

235. Agister's Lien. Though in common law the agister's lien, strictly considered, is not favored, still there are statutes which provide such protection for the man who takes stock to pasture. More frequently we find a recognition of the rights of innkeepers and livery men, with more consideration for these men in the common law. At first glance it might appear strange that such a line should be drawn, granting the right of lien to the innkeeper and refusing it to the man who takes a flock of sheep to pasture, or cattle to feed; but the distinction begins in the essential nature of the case. The agister deals with men whom he knows personally, as a rule, and who reside in neighboring places probably. The customers of the innkeeper, or the livery man, are frequently strangers whose place of residence is often unknown by the bailee. If the bailor is permitted to put his horse in the stable to be cared for for a few days, and then to depart without paying, he might very likely get beyond the convenient reach of the local law, making the collection difficult for the stable keeper. So in the decisions we read "The innkeeper is not bound to deliver the horse until the owner has defrayed the charge for the horse." 37 But the agister's lien does not exist in common law. ${ }^{38}$ A lien for pasturing stock (in 67.

37 In re, The Hostler, Yelv.

88 Hickman v. Thomas, 16 Ala. 666; Lewis v. Tyler, 23

Cal. 364; Auld v. Traris, 5 Colo. App. 535, 39 Pac. 357; Wills v. Barrister, 36 Vt. 220; Tandy $r$. Elmore-Cooper L. S. 
the absence of statutory provision) must be based on a contract, expressed or implied; and in the absence of evidence showing such contract there is no authority to submit the theory of a lien to the jury. ${ }^{39}$ Where the statute provided for an agister's lien it has been held that a man who simply pastured a horse was not entitled to the lien, for he was not in the business of agisting. ${ }^{40}$ So, also, where the statute provided for a lien for livery keepers, it was held that a teamster who kept another horse in the stable with his own horses, but who is neither an innkeeper nor a livery keeper, has no right of lien on the horse. ${ }^{41}$ A person who simply furnishes a certain amount of feed for stock, has no lien. ${ }^{42}$ On the other hand, in Nebraska it was held that one who feeds and cares for stock in pursuance of a contract with the owner has a lien on such stock for such feed and care. ${ }^{43}$

The agister's lien does not cover a servant employed in the care of animals. ${ }^{44}$ A person hired as a groom for specified time has no lien on the horse for his services; but having paid for the food and shoeing he is entitled to a lien for those items, having succeeded to the farrier's rights. ${ }^{45}$

Com. Co., 87 S. W. 614, 113 Mo. App. 409.

39 Cunningham v. Hammill, 84 Mo. App. 389.

40 Seale v. MeCarty, $148 \mathrm{Cal}$. 61, 82 Pac. 845.

41 Goell v. Morse, 126 Mass. 480.

42 W. H. Howard Com. Co. v. National L. S. Bank, 93 Ill. 473.
43 Weber v. Whetstone, 53 Neb. 371,73 N. W. 695.

44 Skinner v. Caughey, 64 Minn. 375,67 N. W. 203 ; Underwood v. Birdsell, 6 Mont. 14\%, 9 Pac. 992 ; Bailey v. Davıs, 19 Ore. 217, 23 Pac. 851; Hooker v. McAllister, I' Wash. 46, 40 Pac. 617.

45 Hoover v. Epler, $52 \mathrm{~Pa}$. 522. 
A lien in favor of those who have kept an animal does not cover an isolated case of feeding. ${ }^{46}$ The owner of a farm is not entitled to a lien on the stock of a farm hand in his employ, though it was pastured on his land, and fed his grain. ${ }^{47}$ Where evidence showed that the defendant took fifty head of cattle it was held to imply that the defendant was in the business and had a lien. ${ }^{48}$

A statute is not retroactive, and gives no right of lien for accounts before it went into effect. ${ }^{49}$

236. Trainer's Lien. The right of a trainer to a lien for his services has been frequently recognized. ${ }^{50}$ The fact that the animal was to be illegally run for bets will not make the contract to train illegal. ${ }^{51}$ The trainer has a common law lien for training and a statutory lien for the keep, according to some decisions. ${ }^{52}$ In one Iowa case it was held that the Iowa law did not give trainer a lien. ${ }^{53}$ A trainer has no lien for shoeing where no charge was made against him for the work. ${ }^{54}$

237. Priority of Right. There has been an apparent disagreement as to the relative rights of an agister, with a lien, and the holder of a mortgage upon the stock. In several cases it has been

46 Conklin v. Carrer, 19 Ind. 226.

47 Wright $\nabla$. Waddell, 89 Iowa, 350,56 N. W. 650 .

48 Bunnell v. Davisson, 85 Ind. 557.

49 Allen v. Ham, 63 Me. 532.

so Bevan v. Waters, 3 C. \& P. 520, 14 E. C. L. 693 ; Jackson .. Holland, 31 Ga. 339; Scott v. Mercer, 98 Iowa, 258, 67 N. W. 108; Allen v. Ham,
63 Me. 532; Shields v. Dodge, 14 Lea, 356.

51 Harris v. Woodruff, 124 Mass. 205.

52 Towle $\nabla$. Raymond, $58 \mathrm{~N}$. H. 64; Farney $\nabla$. Kerr (Tenn.), 48 S. W. 103.

53 Scott $\nabla$. Mercer, 63 Iowa, 325.

$5 *$ Barringer $\nabla$. Burns, $108 \mathrm{~N}$.

C. 606,13 S. E. 142 . 
held that the agister's lien takes supremacy orer the mortgage. ${ }^{55}$ In one case this decision was on the ground that the mortgage was executed while the mortgagee knew that the stock was in the care of the agister. ${ }^{56}$ A mortgage recorded prior to the agistment has been given supremacy of right; ${ }^{57}$ but it has also been held that the mortgagee waives his priority right by his failure to act. ${ }^{58}$

It would seem that the agister's right must be considered as prior to the mortgage so long as the possession of the animals remained in the hands of the mortgagor; ${ }^{59}$ and that after foreclosure his lien would remain supreme against the mortgagee as the new owner.

238. Right of Sale. Either under the statutes or by special contract the agister, or other bailee, may have a right to sell the animals in his care to satisfy his demands. Otherwise his lien would sometimes be of small value; for so long as the animals remain they must be fed and cared for, and these matters imply added expense on his part. But, though he may have a lien upon all the animals agisted, his right of sale only includes so many as may be necessary to cover his claim. The sale of other animals will not be considered as roid, but as voidable. ${ }^{60} \quad(\S \S 232,241$. $) \quad$ The owner

55 Case v. Allen, 21 Kas. 217 ; Corning v. Ashley, 51 Hun, 483; Willard $v$. Whinfield, 2 Kas. App. 53.

56 Tabor $\nabla$. Salisbury, 3 Col. App. 335, 33 Pac. 190.

ธ7 Hanch v. Ripley, 127 Ind. 151,26 N. E. 70; Woodard v. Myers, 15 Ind. App. 42; Bissell v. Pearce, 28 N. Y. 252;
Wright v. Sherman, 3 S. Dak. 290, 52 N. W. 1093,17 L. R. A. 792 .

58 Woodard v. Myers, 15 Ind. App. 42,43 N. E. 573 . 59 Blain v. Manning, $36 \mathrm{Ill}$. App. 214.

60 Whitlock v. Heard, 13 Ala. 776, 48 Am. Dec. 73. 
may replevin his stock sold in excess of the claim, or he may accept the sale and recover the amount received from the bailee. If the statute provides for such sale, the terms of the statute must be strictly observed.61 "At common law the bailec cannot enforce or foreclose his lien by a sale of the property; he only has the right to hold it as security for his debt against the bailor. This has, however, been regulated in most states by statute permitting a public sale of the property, after proper notice of the time and place, to satisfy the amount of the lien." 62

239. Estrays and Trespassing Animals. A landowner finding cattle trespassing upon his premises may simply drive them off, or he may impound them, either on his own premises or in a public pound. If they have done damage upon his premises he may bring action against the owner, or he may hold them as a bailee holding a lien upon them for the damage done. If there is a law governing the matter, that law must be strictly observed. He must not injure the animals, either in his driving them off, nor in his impounding them. If in any way he misuses them he is liable to an action in trespass. ${ }^{63}$ Animals distrained, or taken as security for the damage they have done, must be captured in the act. ${ }^{4}$ They cannot be distrained after they have left the field. ${ }^{65}$ But

01 Greenawalt v. Wilson, 52

Kas. 109, 34 Pac. 403.

62 Van Zile, Bailments and Carriers, 75.

63 Wilson v. McLaughlin, 107 Mass. 587 ; Murgoo v. Cogswell,

1. E. D. Smith 359 . 64 Harriman v. Fifield, 36 Vt.
341; Lindon r. Hooper, Corp. 414.

65 Holden v. Torrey, 31 Vt. 690 ; Warring v. Cripps, 23 Wis. 460 ; MeIntyre v. Lockridge, 28 U. C. Q. B. 204; Graham v. Spettigue, 12 Ont. App. 261. 
having left the field in which they did the damage, they may still be impounded if in a different field. ${ }^{66}$ When thus distrained they must be kept strictly confined; it is not sufficient to put them in a pasture. ${ }^{67}$ The distrainer's lien is waived by the release of the stock; ${ }^{68}$ and it is extinguished by a tender of payment for damages. ${ }^{69}$ The distrainer must give such legal notice as is provided by the law. The lien may be lost by a failure to advertise, ${ }^{70}$ or by putting the animals to work. ${ }^{71}$ It is no excuse for failure to adrertise, as the law required, that the owner has identified his animals and promised to prove ownership. ${ }^{72}$ But when the owner sent word that the finder need not advertise the horse, the owner is estopped from making the failure to advertise a ground for failure to pay for the keep..$^{73}$ The taker up of animals estrayed contrary to law, or distrained for trespassing, has a lien for lawful charges. ${ }^{74}$

Where the law provides that the distrainer, or finder of an estrayed animal may sell the animal, but requires that a notice be sent to the owner

66 McKeen v. Converse, 68 N. H. 173, 39 Atl. 435.

67 Harriman v. Fifield, $36 \mathrm{Vt.}$ 341.

68 Dunbar v. DeBoer, 44 Ill. App. 615.

69 MePherson $\nabla$. James, 69

Ill. App. 337; Leavitt v. Thompson, 52 N. Y. 62.

70 Cory v. Dennis, 93 Ala. 440, 9 So. 302; MeMillan v. Andrew, 50 Ill. 282.

71 Weber $v$. Hartman, $7 \mathrm{Col}$.
13, 1 Pac. 230; Parker v. King, Ga. Dec. Pt. 1, 131.

72 Wright v. Richmond, 21 Mo. App. 76.

73 Campbell v. Headon, 89 Ill. App. 172.

74 Garabrant v. Vaughn, 2 B. Mon. 327 ; Ford $\nabla$. Ford, 3 Wis. 399 ; Mahler $v$. Holden, 20 Ill. 363 ; Logan 5. Marquess, 53 Ind. 16; Rice v. Underwood, 27 Mo. 551. 
previous to the sale, if the animal be sold without such notice the owner can recover possession without paying the lien. ${ }^{75}$

240. Waiver of Lien. As a general rule a lien is lost when the bailee parts voluntarily with possession; he abandons his lien thereby. ${ }^{76}$ But if an agister temporarily leaves the stock to be herded by another, and the stock be driven off by the owner in his absence, the lien is not lost. ${ }^{77}$ A tender of the amount really due under the lien extinguishes the lien, though the bailee may sue for the larger amount claimed. ${ }^{78}$ As previously mentioned, a lien may be lost by putting the animal to work, or by unlawful sale. The lien is also lost by refusal to deliver on some other ground, or by an agreement to give credit, or by sending word simply to come and get the animal held. (\$ 82.)

241. Illegal Sale by Bailee. The finder of an article lost has a title thereto subject only to the right of the owner; but a bailee has no real title to the things in his possession. If, therefore, the bailee should unlawfully sell animals in his possession he can give no title thereto, and the owner may recover possession from the third party, who may have been a bona fide purchaser, who may have bought in ignorance of the vendor's lack of

75 Bailey v. O'Fallon, $30 \mathrm{Col}$. 419, 70 Pac. 755.

76 Fishell v. Morris, 57 Conn. 547, 18 Atl. 717; Wright v. Waddell, 89 Iowa, 350, $56 \mathrm{~N}$. W. 650 ; Danforth v. Pratt, 42 Me. 50; McPherson First Nat. Bank v. Barse Live S. Com. Co., 61 Mo. App. 143; Powers v. Botts, 58 Mo. App. 1; Kroll $\nabla$.
Ernst, 34 Neb. 482, 51 N. W. 1032; Cardinal v. Edwards, 5 Nev. 36.

77 Willard v. Whinfield, 2 Kas. App. 53, 43 Pac. 314; Weber v. Whetstone, 53 Neb. 371,73 N. W. 695.

78 Berry v. Tilden, 70 Мo. 489 . 


\section{ESSENTIALS OF VETERINARY LAW}

title. $^{i 9}$ The innocent purchaser must get his satisfaction from the vendor or not at all.

242. Lien Once Lost Cannot Be Revived. A lien once lost cannot be revived. ${ }^{80} \quad(\S 82$.

72 Calhoun v. Thompson, 5616 Ohio, 431; Dunham v. Lee, Ala. 166; Lovejoy v. Jones, 30 24 Vt. 432.

N. H. 164; Johnson v. Miller, 80 Van Zile, Op. cit. 73. 


\section{TABLE OF CASES CITED}

Adams, (ex. rel.) v. Burdge, 95 Wis. 390,70 N. W. 347 ,

37 L. R. A. $157 \ldots \ldots \ldots 149$

Adams r. Milwaukee, 144

Wis. 371,129 N. W. 518. .....11, 154, 169, 171, 173

Adams v. Milwaukee, $228 \mathrm{U}$.

S. $572.11,154,169,171,173$

Adams (Adms.) v. Stewart,

5 Har. 144........... 93

Aiton v. Board of Medical

Examiners, 13 Ariz. 354,

114 Pac. 962 .......... 60

Allen v. Allen, 2 P. \& W.

$166 \ldots \ldots \ldots \ldots \ldots \ldots 248$

Allen v. Ham, 63 Me. 532

..............105, 285

Allen v. State, 42 Tex. 517.252

Allison v. Cash, 143 Ky. 679,

137 S. W. 245, 21 Cyc. 405.

............. 148, 151

Almond v. Nugent, 34 Iowa, 300,11 Am. R. $147 \ldots . .76$

Allopathic State Board of

Med. Exrs. v. Fowler, 50

La. Ann. 1358, 24 So. 80952

American Preservers' Co. v.

Drescher, 4 Misc. (N. Y.)

482,24 N. Y. S. $361 \ldots 278$

Angus Cattle Co. v. McLeod,

(Neb.) 152 N. W. 322...261

Anson v. Dwight, 18 Iowa,

$241 \ldots \ldots \ldots \ldots . .98,233$

A pothecaries' Co. v. Bentley,

1 C. \& P. $538 \ldots \ldots \ldots \ldots .93$
Arbuckle $\nabla$. Pflaeging, 20 Wy. 351, 123 Pac. 918... 143

Arkansas Val. L. etc. Co. v. Mann, 130 U. S. $69 \ldots . .247$

Armour \& Co. v. Augusta, 134 Ga. 178, 67 S. E. 417.199 Asheville v. Nettles, $164 \mathrm{~N}$.

C. 315,80 S. E. $236 \ldots .168$ Atterberry v. State, 19 Tex.

App. 401 ..........250

Attorney General v. Birmingham, Tame \& Rea D. Dist. L. R. C. D. (1910) $1 \mathrm{Ch}$. $48 \ldots \ldots \ldots \ldots \ldots \ldots . \ldots 38$

Attorney General v. Churchill's Veterinary Sanatorium, Ltd., 79 L. J. Ch. 714, (1910) 2 Ch. 401... 67 Attorney General v. Myddleton's Ltd. (1907) 1 J. R. $471 \ldots \ldots \ldots \ldots \ldots \ldots 67$ Atzroth v. State, 10 Fla. 207.253 Aubuchon v. Pohlman, 1 Mo.

App. 298 ..........25s August Brandt \& Co. v. Verhagen, (Wis.) $152 \mathrm{~N}$. W. $448 \ldots \ldots \ldots \ldots \ldots \ldots .248$

Auld v. Travis, 5 Co. App. 535, 39 Pac. $357 . \ldots \ldots .283$ Austin v. Miller, 74 N. C. $274 \ldots \ldots \ldots \ldots \ldots . .278$

Bacon v. Walker, 204 U. S. 311 ............... 25

Bailey v. Davis, 19 Ore. 217, 23 Pac. 881 .......... 284 
Bailey v. O'Fallon, $30 \mathrm{Col}$. 419, 70 Pac. 755 .......289

Barbour v. Martin, $62 \mathrm{Me}$. $536 \ldots \ldots \ldots \ldots \ldots . \ldots 7$

Barnes, Ex parte, and

Barnes v. State, 83 Neb. 433, 119 N. W. $662 \ldots \ldots \ldots .47$

Barney v. Pinkham, 29 Neb. 350,45 N. W. 694, 26 Am. St. R. $389 \ldots \ldots \ldots \ldots .75$

Barringer v. Burns, $108 \mathrm{~N}$.

C. 606,13 S. E. $142 \ldots \ldots 285$

Barrus v. Phaneuf, 166 Mass.

123,44 N. E. $141 \ldots .122,123$

Barse Live Stock Com. Co. v. Adams, 2 Ind. Ter. 119, 48 S. W. 1023 .........281

Bartlett v. Lockwood, 160

U. S. $357 \ldots \ldots \ldots \ldots 147$

Bass v. Cantor, 123 Ind. 444, 24 N. E. $147 \ldots \ldots .271,274$

Bassett v. Collis, 2 Camp. 523 ...............243

Batley v. Kynock, L. R. 20

Eq. Cas. 632 .........122

Bear v. Cedar Rapids, 147 Iowa, 341, 126 N. W. 324, 27 L. R. A. (N. S.) 1150.167

Beatty v. Cullingsworth, Q. B. D., 44 Cent. L. J. 153 . 89 Beck v. German Klinik, 78 Iowa, $696,43 \mathrm{~N}$. W. 617 . . 79 Becker v. Janiski, 15 N. Y. Sup. 675, 27 Abb. N. C. $45 \ldots \ldots \ldots \ldots 70,71,73$

Beeks v. Dickinson Co., 131 Iowa, 244, 108 N. W. 311, 6 L. R. A. (N. S.) $831 \ldots 151$ Belknap v. Belknap, $20 \mathrm{~S}$. Dak. 482, 107 N. W. 692..253

Bellinger v. Craigue, 31 Barb. 534 ......... 87

Bellows v. Denison, 9 N. H. 293 ...............276
Bellows v. Raynor, $207 \mathrm{~N}$. Y. 389, 101 N. E. 181...169

Bernard v. Willamette Box \& Lumber Co., 64 Ore. 233, 129 Pac. $1039 \ldots \ldots . .39$

Berry v. Tilden, 70 Mo. 489.289

Berry v. State, (Tex.) $135 \mathrm{~S}$. W. $631 \ldots \ldots \ldots 661,76$

Best v. Osborne, Ry. \& Mo. 290 ..............242

Best v. Vedder, 58 How.

Prac. 187 .......... 81

Bevan v. Waters, 3 C. \& P. 520,14 E. C. L. $693 \ldots 285$

Beyman v. Black, 47 Tex. $588 \ldots \ldots \ldots \ldots \ldots 252$

Bigelow v. Maine Cent. R. R. Co., 110 Me. 105, 85 Atl. $396 \ldots \ldots \ldots \ldots \ldots 200$

Bissell v. Pearce, 28 N. Y.

$252 \quad \ldots \ldots \ldots \ldots \ldots 286$

Black v. Vaughan, 70 Tex. 47,7 s. W. $604 \ldots \ldots 250$ Blain v. Manning, 36 Ill. App. $214 \ldots \ldots \ldots \ldots 286$ Blair v. Bartlett, $75 \mathrm{~N}$. Y. $150 \ldots \ldots \ldots \ldots \ldots .68$

Blair v. Forehand, 100 Mass. $136 \ldots \ldots \ldots \ldots \ldots 230$

Blazier v. Miller, $10 \mathrm{Hun}$ $435 \ldots \ldots \ldots \ldots .154,173$

Board of Health v. Tupper, 210 Mass. 378, 96 N. E. 1096 ............. 24

Board of Liquidation v. Mc-

Comb, 92 U. S. 531......138

Board of Medical Examiners v. Clausen, (Wash.) 146 Pac. 630 ........... 63

Board of Medical Examiners v. Eisen, 61 Ore. 492, 123 Pac. 52 ..........6 61

Board of Trade v. People, 91 Ill. $88 \ldots \ldots \ldots \ldots .54$ 
Bodger v. Nicholls, 28 L. T.

N. S. 441 ........240

Boldt v. Murray, 2 N. Y. St.

R. 232, affirmed, $113 \mathrm{~N}$. Y.

670,21 N. E. $1116 \ldots \ldots .75$

Bonham's Case, 8 Coke, 107 a 45

Boom v. Reed, 69 Hun, 426,

23 N. Y. Sup. $421 \ldots \ldots 72$

Boor v. Lowery, 103 Ind.

468, 53 Am. St. R. 519, 3

N. E. $151 \ldots \ldots \ldots$. 81

Borden v. Board of Health,

Montclaire, 81 N. J. L.

(52 Vrom.) 218, 80 Atl.

$30 \ldots \ldots \ldots \ldots \ldots 11,171$

Bower v. Smith, 8 Ga. 74.. 93

Breckenridge Co. v. McDonald, $154 \mathrm{Ky} .721,159 \mathrm{~S}$.

W. 549 .............140

Brenan v. Currint, Say. 224.104

Brent v. Kimball, 60 Ill. 211.234

Briggs v. Hunton, $87 \mathrm{Me}$. 145, 32 Atl. 794, 47 Am.

St. R. 318........255, 256

Brimmer v. Rebman, 139 U.

S. $75 \ldots \ldots \ldots \ldots 199,200$

Bronson v. Hoffman, 7 Hun, $674 \ldots \ldots \ldots \ldots \ldots . \ldots 75$

Brooke v. People, 23 Col.

375, 48 Pac: 502 .......251

Brown v. Doyle, 69 Minn.

543 ..............245

Brown v. Maryland, 12

Wheat. 419 ...........147

Brown v. Mattingly, $42 \mathrm{Ky}$. 592 .256

Brown v. Purdy, 8 N. Y. St., R. 143 .............145

Brown v. Robinson, 1 C. \& P. $264 \ldots \ldots \ldots . \ldots 93$

Browne v. Livingston Co. 126

Mich. 276 .........145

Bruns v. State, 33 Tex. Cr.

415,26 S. W. $722 \ldots .5,253$
Buchman v. State, 59 Ind. 1, 26 Am. R. 75.....122, 124

Buck v. Brady, 110 MId. 568, 73 Atl. 277.......152, 233

Buckmaster v. Smith, 22 vt., 203 .............. 249

Budd v. McLaughlin, 10 Manitoba, 75 .......245

Bunnell v. Davisson, 85 Ind. 557 ..............285

Burnham v. Jackson, 1 Col. App. $237 \ldots \ldots \ldots \ldots 77$

Burns v. Barenfield, 84 Ind. 43 ...................119

Busfield v. Wheeler, 14 AI-

len, (Mass.) $139 \ldots \ldots .110$

Bushnell v. C. B. \& Q. R. R. Co., 259 Ill. 391, $102 \mathrm{~N}$. W. 785

Caldwell v. Bridal, 48 Iowa, 15 ................241

Calhoun v. Thompson, 56 Ala. 166 .......250, 290

California Reduc. Co. v. Sanitary Red. Works, 199 U. S. 306 .............154

Campau v. Langley, 39 Mich. $451 \ldots \ldots \ldots \ldots \ldots 230$

Campbell v. District of $\mathrm{Co}$ lumbia, 19 App. D. C. 131.232 Campbell v. Headon, S9 Ill. App. 172 .........28s

Campbell v. Page, 67 Barb. 113 ..............274

Cardinal v. Edwards, 5 Neb. 36 ...........109, 289

Carpenter v. Blake, 60 Barb. $488 \ldots \ldots \ldots \ldots \ldots 75,79$

Carpenter v. Cook, 67 Vt. 102, 30 Atl. 998......264 Case v. Allen, 21 Kas. 217. .286 Casey v. Donovan, 65 Mo.

App. 521 .........278 
Carender v. Fair, 40 Kas. 182, 19 Pac. 638.......259

Chamberlain v. Gage, 20 Iowa, 303 ..........254

Chapman v. Muskegon Co., 169 Mich. 10, 134 N. W. 1025 16

Chapman, Ex rel., v. Board of Med. Exmrs., 34 Minn. 387,26 N. W. $123 \ldots \ldots 60$

Chase v. Nelson, 39 Ill. App. 53 87

Chenowith v. State Board of Med. Exrs., 57 Col. 74, 141 Pac. 132 ..........6 61

Chestnut v. People, $21 \mathrm{Col}$. 512, 42 Pac. 656.......252

Chicago v. Bowman Dairy Co., 234 IIl. 294, 84 N. E. 294 ................173

Chicago \& A. R. R. Co. v. Erickson, 91 Ill. 613, 33 Am. Rep. 70 ........5, 148 Chicago v. Weber, 246 Ill. 304, 92 N. E. $859 \ldots \ldots . .32$

Christian Co., Ex rel., v. Gordon, (Mo.) 176 S. W. 1.. 12 Church v. Knowles, $101 \mathrm{Me}$. $264 ; 63$ Atl. 1042.....247 Clarendon Land, ete. Co. v. MeClelland, 89 Tex. 483, 34 S. W. 98,35 S. W. 474.260 Cleveland v. Spier, 16 C. B. (N. S.) 399 , MeClelland, Civ. Mal. 508.......77 Coggs v. Bernard, 2 Ld. Raym. 909 .........275

Cole v. Hall, 103 Ill. $30 \ldots 233$ Collins v. Bennett, 46 N. Y. $490 \ldots \ldots \ldots \ldots 277,278$

Collins v. State, 32 S. C. R. (U. S.) 286, 223 U. S. 28849 Commonwealth v. Brandon, $43 \mathrm{Ky} .2 \ldots \ldots \ldots .255$
Commonwealth v. Drew, 208 Mass, 493, 94 N. E. 682..172 Commonwealth v. Gilbert, 160 Mass. 157, 35 N. E. 454 ..............231

Commonwealth v. Harris, 47 Ку. 373 .........255

Commonwealth v. Rice, 93 Ky. 393, 20 S. W. 431 .. 51 Commonwealth v. Spring, 19 Pick. 396 ......... 58

Commonwealth v. Wheeler, 205 Mass. 384, 91 N. E. $415 \quad \ldots \ldots \ldots \ldots \ldots .6167$

Concklin v. Havens, 12 Johns. 314 .........248

Conklin r. Carver, 19 Ind. 226 ...............285

Conkey v. Carpenter, 106 Mich. 1, 63 N. W. 990.. 92 Conner v. Winton, 8 Ind. 315, 65 Am. St. Dec. 761. 75 Conwell v. Smith, 8 Ind. 530.256 Copeland v. Draper, 157 Mass. 588, 19 L. R. A. 283, 32 N. E. 944 ........276

Corn v. State, 41 Tex. 301.252 Corning v. Ashley, 51 Hun, 483 ...............286

Cory v. Dennis, 93 Ala. 440, 9 So. $302 \ldots \ldots$.......2ss

Costello r. Ten Eyck, 86 Mich. 348, 49 N. W. 152..260

Courtney v. Henderson, ( $\mathrm{Na}$ rine Court, N. Y.) McClelland, Civ. Mal. 273 .............. 76,77

Covington Board of Health v. Kollman, $156 \mathrm{Ky} .351$, 160 S. W. 1052 ..........173

Cowles v. Balzer, 47 Barb. 562 .............264 Coyle v. Campbell, $10 \mathrm{Ga}$. $570 \ldots \ldots \ldots \ldots . . . .694$ 
Craig v. Chambers, 17 Ohio St. $253 \quad \ldots \ldots \ldots \ldots .75$

Cranston v. Mayor of Augusta, 61 Ga. 572.....2230 Cubit ז. O'Dett, 51 Mich. 347,16 N. W. $679 \ldots \ldots 133$ Cummings v. Harris, 3 Vt. 244, 23 Am. Dec. 206....281 Cummings $\nabla$. Perham, 42 Mass. 555 ........6, 233

Cunningham v. Hammill, 84 Mo. App. $389 \ldots \ldots .284$ Cunningham v. Macon R'. R. Co. 109 U. S. $446 \ldots \ldots 138$

Dade v. United States, 40 App. D. C. $94 \ldots \ldots \ldots 173$ Dale v. Donaldson Lumber Co., 48 Ark. 188, 2 S. W. 703 87

Danforth \& Co. v. Crookshanks, 68 Mo. App. 311 .............241, 244

Danforth v. Pratt, 42 Me. $50 \ldots \ldots \ldots \ldots 104,109,289$

Davidson v. New Orleans, 96 U. S. 97 .........151

Davis v. Commonwealth, 17 Grat. 617 .........233

Davis v. Randall, 97 Me. 36 , 53 Atl. 835 .........255

Dean v. Keate, 3 Camp. 4..273

Decisions 2583, 2584, Food \& Drugs Act .........197

Deems v. Mayor of Baltimore, 80 Md. 164, 30 Atl. 648, 26 L. R. A. 541...154, 173 Deeves v. Lockhart, $51 \mathrm{~N}$. Y. Super. Ct. $302 \ldots \ldots .87$

DeGarca v. Galvin, 55 Tex. 53 ..............252

Dement, Ex parte, 53 Ala. 389
Dent $\nabla$. West Virginia, 129 U. S. $114 \ldots \ldots \ldots .46,49,52$ Dickerson v. Gordy, 5 Rob. (La.) 489 ......... 93 Dills v. State, 59 Ind. 15.122 District of Columbia v. Lynham, 16 App. D. C. $85 . .167$ Dix v. Sommerset Coal Co., 217 Mass. 146, 104 N. E. 433 ...............262

Dixon v. People, 168 Ill. $179 \ldots \ldots \ldots \ldots \ldots . . . \ldots 122$

Dixon v. State, 19 Tex. 134.251 Dorion v. Jacobsen, $113 \mathrm{Ill}$. App. 563 ......... 96

Driscoll v. Commonwealth, 93 Ky. 393, 20 S. W. 431. 51 DuBoise v. Decker, $130 \mathrm{~N}$. Y. 325,29 N. E. 313,14 L. R. A. $429 \ldots \ldots \ldots \ldots 76$

Duckworth v. Walker, 1 Jones Law, (46 N. C.) 507 ...............243

Duffees v. Judd, 48 Iowa, $256 \ldots \ldots \ldots \ldots 264$

Dunbar v. Deboer, 44 Ill. App. 615 ..........28s

Dunham v. Lee, 24 Vt. 432 $.280,290$

Dunning v. Crofutt, 81 Conn. 101, 70 Atl. $630 \ldots \ldots .247$ Durgin v. Minot, 203 Mass. 26,89 N. E. $144 \ldots \ldots .40$ Dusaw v. State Veterinary Board, 157 Mich. 246, 121 N. W. $759 \ldots \ldots \ldots \ldots$... 50

Easter v. Goyne, 51 Ark. 222,11 S. W. $212 \ldots . .259$

Eastman v. State, 109 Ind. 278,10 N. E. $97 \ldots \ldots 49$

Ebner v. Mackey, 186 Ill. 297,57 N. E. $834 \ldots \ldots .71$ 
Eckhardt v. Buffalo, $156 \mathrm{~N}$. Y. 658,50 N. E. $1116 \ldots 40$

Edwards v. Carr, 13 Gray, (Mass.) 234 ........273

Edwards v. Lamb, 69 N. H. 599, 45 Atl. 480,50 L. R. A. $160 \ldots \ldots \ldots \ldots .64$

Edwards v. Osman, 84 Tex. 656,19 S. W. $868 \ldots \ldots 252$

Eichenlaub v. St. Joseph, 113 Mo. 395, 18 L. R. A. $590 \ldots \ldots \ldots \ldots . . .27$

Elgin R'oad Trustees v. Innes, 14 Rettie, (Sc. Ct.

Sess.) $48 \quad \ldots \ldots \ldots \ldots 265$

Elmore v. Fitzpatrick, 56 Ala. 400 ............249

Elsner v. State, 22 Tex. App. 687,3 S. W. $474 \ldots \ldots .252$

Elton v. Brogden, 4 Camp. $281 \ldots \ldots \ldots \ldots .242,244$

Elton v. Jordan, 1 Stark, 127 ..........242, 244

Ely v. Thompson, 3 A. K. Marsh, 70 .........138

Ely v. Wilbur, 48 N. J. L. 685

Eshleman v. Union Stockyards Co., 222 Pa. 20, 70 Atl. 899 ........136, 153

Espy v. State, 32 Tex. 375 $.249,250$

Faith v. State, 32 Tex. 373 .............249, 250

Faris v. Lewis, 2 B. Mon. 375 ................241.

Farkas v. Powell, 86 Ga. 800 , 12 L. R. A. 397,13 S. E. 200 ...............280 Farney v. Kerr, (Tenn.) 48 S. W. $103 \ldots \ldots \ldots \ldots 285$ Farrar v. Andrew Peterson \& Co., 72 Wash. 482,130 Pac. 753,44 L. R. A. (N.
S.) 1092 ; affirmed on rehearing, 133 Pac. 594, 44 L. R. A. (N. S.) 1094. . $.153,262$

Farrell v. Manhattan Market Co., 198 Mass. 271, 84 N. E. 481,15 L. R. A. (N. S.) 884 ........200

First National Bank v. Barse Live Stock Com. Co., 61 Mo. App. 143.......109, 289

First National Bank v. Eichmeier, 153 Iowa, 154, 133 N. W. $454 \ldots \ldots \ldots 247$ First National Bank v. Hughes, 5 Cal. U. C. 454, 46 Pac. 272 ........245

Fishell v. Morris, 57 Conn. 547, 18 Atl. 717,6 L. R. A. $82 \ldots \ldots \ldots$....109, 289

Fisher v. Clark, 41 Barb. 329 ..............260

Fisher v. MeGirr, 1 Gray, 1.138 Fitzgerald v. Evans, 49 Minn. 541,52 N. W. 143.120 Fletcher v. Rhode Island, 5 How. 504 ...........146 Fletcher v. Jacob Dold Packing Co., 58 N. Y. S. 612; Affd. 169 N. Y. 571, 61 N. E. $1129 \quad \ldots \ldots \ldots \ldots 247$ Flinn v. Prairie Co., 60 Ark. 204, 29 S. W. $459 \ldots \ldots .122$ Florey v. State, 13 Tex. App. 655 ...............250 Folsom v. State Veterinary Board, 158 Mich. 277, 122 N. W. $529 \ldots \ldots \ldots$... 50 Fonville v. Casey, 1 Murph. (N. C.) 389 ......2.249 Ford v. Ford, 3 Wis. $399 . .288$ Foreman v. State Board of Health, (Ky.) 162 S. W. $796 \ldots \ldots \ldots \ldots .6 .61$ 
Fort v. City of Brinkley, 87 Ark. 400, 112 S. W. 1084. 63 Fossett v. State, 11 Tex. App. 40 ..........254

Foster v. Swope, 41 Mo. App. 137 .........265

French v. Vining, 102 Mass.

132, 3 Am. St. R. 440. . .200 Fuller, Ex rel., v. Board of Med. Exmrs., 34 Minn. 391,26 N. W. $125 \ldots \ldots 60$

Gaines v. Waters, 64 Ark. 609 .............. 31

Gallaher v. Thompson, Wright, (Ohio) 466.... 92 Galveston Land \& Imp. Co. v. Pracker, 3 Tex. Civ. App. 261, 22 S. W. 830..265 Garabrant v. Vaughn, 2 B. Mon. 327 .........28 Gardner v. Michigan, 199 U.

S. $325 \quad \ldots \ldots \ldots \ldots \ldots 154$

Garth $\nabla$. Everett, 16 Mo. 490 ...........248, 249

Gates $v$. Preston, 41 N. Y. $113 \ldots \ldots \ldots \ldots \ldots . . . .87$

Geer v. Connecticut, $161 \mathrm{U}$.

S. $519 \ldots \ldots \ldots \ldots 231$

Georgia N. R. Co. v. Ingram, 114 Ga. 639,40 S. E. 708. 87 Gerken จ. Plimpton, $70 \mathrm{~N}$.

Y. Sup. $793 \ldots \ldots \ldots \ldots .72$ Glidden v. Pooler, 50 Ill.

App. 36 ..........244

Goble v. Dillon, 86 Ind. 327.87

Goell v. Morse, 126 Mass..

480 ...............284

Gore v. Brockman, 138 Mo.

App. 231, 119 S. W. 1082. 76 Graham v. Gautier, 21 Tex.

$111 \ldots \ldots \ldots \ldots .76,79$ Graham v. Spettigue, 12 Ont.

App. 261 ..........287
Gramm v. Boener, 56 Ind. $497 \ldots \ldots \ldots \ldots \ldots \ldots$

Grattop v. Rowheder, 1 Neb. 660,95 N. W. $679 \ldots \ldots .96$

Graves $\nabla$. Moses, 13 Minn. 335 ...............275

Grayson v. Lynch, 163 U. S. 468 ................260

Green v. Higenbotam, $3 \mathrm{~N}$.

J. L. $60 \ldots \ldots \ldots \ldots \ldots .94$

Greenawalt v. Wilson, 52

Kas. 109, 34 Pac. 403....257

Grinnell v. Cook, 3 Hill, 485,

38 Am. Dec. 663 .......258

Grossman v. Oakland, 36 L.

R. A. 593, 30 Ore. 478,

41 Pac. 5 ........... 30

Haag v. City of Mt. Vernon, 58 N. Y. S. 585, 41 App.

Div. 366 .......... 40

Haire v. Reese, 7 Phia. 138. 87 Halty v. Markel, 44 Ill. 225.260 Hamilton v. McLoughlin, 145 Mass. 20 ..........110

Hanch v. Ripley, 127 Ind. 151,26 N. E. $70 . \ldots \ldots 286$

Hancke v. Hooper, 7 Car. \& P. $81 \ldots \ldots \ldots \ldots .81,92$

Hanley v. Kansas City S. Ry. Co., 187 U. S. $617 \ldots 147$ Hannibal \& St. Jos. R. R. Co. v. Husen, 5 Otto, 465 .......5, 14, 139, 148, 149 Harby v. Wells, 52 S. C. 156, 29 S. E. $563 \ldots \ldots \ldots . .259$ Hargan v. Purdy, $93 \mathrm{Ky}$. 424,20 S. W. $432 \ldots . .51$ Harriman v. Fifield, 36 Vt. 341 ..........287, 288

Harrington v. Snyder, 3

Barb. 380 ..........274 Harris $\nabla$. Woman's Hosp., 14 N. Y. Supp. $881 \ldots . .70$ 
Harris v. Woodruff, 124 Mass. $205 \ldots \ldots \ldots \ldots 285$

Hart v. Vidal, 6 Cal. 56...117 Hathorn v. Richmond, $48 \mathrm{Vt}$. 557 ............. 76

Havey v. Petrie, 100 Mich. 190 ..............240

Hawker v. New York, 170

U. S. $189 \ldots \ldots \ldots 46,49,61$

Hawkins v. Haynes, 71 Ga. 40 ...............273

Hawkins v. Hoye, (Miss.) 66 So. $741 \ldots \ldots \ldots 11,171$

Heath v. Glison, 3 Ore. 64 .. 76

Heisrodt $\nabla$. Hackett, 34 Mich. 283, 22 Am. S. Rep. 529 ............. 98, 233

Helland v. Bridenstine, 55 Wash. 470, 104 Pac. 626. 85 Henderson \& Campbell $\vee$. Hall \& Hughes, 87 Ark. 1, 112 S. W. $171 \ldots \ldots \ldots . .103$

Hensel v. Noble, 95 Pa. 345 .281, 282

Herber v. State, 7 Tex. 69. .252 Herndon v. City of Springfield, 137 Mo. App. 513, 119 S. W. $467 . \ldots \ldots \ldots .102$

Herrick v. Gary, 65 Ill. 101.152 Herrick v. Gary, 83 Ill. 85.260 Hewett v. Board of Medical Examiners, 148 Cal. 590, 84 Pac. 39 ......... 59

Hewett v. Woman's Hospital Aid Assn., $73 \mathrm{~N}$. II. 556, 64 Atl. 190, 7 L. R. A. (N. S.) $496 \ldots \ldots .84$ Hibbard v. Thompson, 109 Mass. 286 ......... 88 Hickman v. McMorris, 149 Ky. 1,147 S. W. $768 . .16,139$ Hickman v. Thomas, 16 Ala. 666 .283
Highland v. Schulte, 123 Mich. 360,82 N. W. 62 . 139 Hill v. Ball, 2 H. \& N. 298.239 Hillyard v. Grand Trunk Ry. Co. 8 Ont. $583 \ldots \ldots \ldots 266$ Hine v. New Haven, 40 Conn. 478 ..............27

Hitchcock v. Burgett, 38 Mich. $501 \ldots \ldots \ldots 80,88$ Hoag v. Orange Mt. Lnd. Co., 12 N. J. L. Jour. 243 ...............265

Hoffman v. Oats, 77 Ga. 701 ...............242 Holden v. Torrey, $31 \mathrm{Vt}$. 690 ...............287

Homer v. Thwing, 3 Pick. 492 ...............275

Hooker v. MeAllister, 12 Wash. 46, 40 Pac. 617...284 Hoover v. Epler, 52 Pa. 522 ..............104, 284 Hostler, The, In re, Yelv. 67 ................283 Houska v. Hrabe, S. Dak. 151 N. W. 1021 .......261 Houston v. State, 13 Tex. App. 595 ..........250 Howard v. Babeock, $21 \mathrm{ml}$. 259 .............271

Howard Com. Co. v. National L. S. Bank, 93 Ill. App. 473 ..............284 Howell v. Smith, 108 Mich. 350,66 N. W. $218 \ldots \ldots 117$ Hoyt v. MeLoughlin, $250 \mathrm{Ill}$. 442,95 N. E. $464 \ldots \ldots \ldots .37$ Hubbard v. Allyn, 200 Mass. 166, 86 N. E. $356 \ldots \ldots . .132$ Hull v. Hull, 48 Conn. 250, 40 Am. R. $165 \ldots$......249 Humphrey v. Dunnells, 21 Cal. App. 312, 131 Pac. 761 
Hunt v. Gray, 35 N. J. L. $227 \ldots \ldots \ldots \ldots . . .243$

Hunt v. State, 33 Tex. Crim. 93,25 S. W. $127 \ldots \ldots 254$

Hurd v. Lacy, 93 Ala. 427, 9 So. $378 \ldots \ldots \ldots \ldots 265$

Hurley v. Eddingfield, 156 Ind. 416,59 N. E. 1058 , 53 L. R. A. $135 \ldots . \ldots 70$ Hurst v. Warner, 102 Mich. 238,60 N. W. $440 \ldots \ldots 148$ Hutton v. State, 7 Tex. Crim. App. 44 .........252 Hyrne v. Erwin, 23 S. C. 226 , 55 Am. R. $15 \ldots$.... so, 81

Jackson, Cook \& Co. v. Holland, 31 Ga. 339...258, 285 Jacobson v. Massachusetts, 197 U. S. $11 \ldots \ldots \ldots 46$ Jamey, Ex rel., v. Housekeeper, 70 Md. $162 \ldots . .8$ ? Jarvis v. Riggin, 94 Ill. 164 ............ 148, 150

Jeff rey v. Bigelow, 13 Wend. 518 .241

Jenkins $\nabla$. Board of Education, 234 Ill. $422,84 \mathrm{~N}$. E. $1046 \ldots \ldots \ldots \ldots$.

Jenkins v. French, 58 N. H. 532 .............. 81

Jennings $\nabla$. State Veterinary Board, 156 Mich. 417, 120 N. W. $785 \quad \ldots \ldots \ldots \ldots$. 50

Jew Ho v. Williamson, 103 Fed. 10 .............145

Johnson v. Lewis, 151 Wis. 615,139 N. W. $377 \ldots .234$

Johnson v. Miller, 16 Ohio, 431 ...........280, 290

Johnson v. Simonton, 43 Cal. 242 ..............170

Johnson v. State, 1 Tex. A $\left.{ }^{1}\right) .333$.........252
Johuson v. Steam Gauge \& Lantern Co., $146 \mathrm{~N}$. Y. 152,40 N. E. 773 , affirming 72 Hun, 535,25 N. Y.

Sup. 639 ...........119 Jones v. Angell, 85 Ind. 376.88 Jones v. Bright, 5 Bing. 533.244 Joy v. Bitzer, 77 Iowa, 73..241 Judah v. McNamee, 3 Blackf. 269 .............. 94

Kaiahua, In re, 19 Ha. 218.145 Kansas City v. Sihler Hog Cholera Serum Co., 87 Kas. 786, 125 Pac. 70. Sustained, 88 Kas. 164, 127 Pac. $540 \ldots \ldots . . .32$

Kearnes v. Caldwell, $7 \mathrm{Ky}$. L. $450 \ldots \ldots . \ldots \ldots 96$

Keith v. Lothrop, 64 Mass. 453 ...............119

Kelley v. Grundy, $20 \mathrm{Ky}$. L. 1081,45 S. W. $100 \ldots .24 \mathrm{~s}$

Kelley v. Tillourey, 81 Conu. 320,70 Atl. 1031......234

Kellogg v. Loveley, 46 Mich. 131, 8 N. W. 699, 41 Am. Rep. 151 ..........248

Kempster $v$. Milwaukee, 97 Wis. $343,79 \mathrm{~N}$. W. $743 \ldots 133$

Keunedy v. Board of Health, 2 Pa. $366 \ldots \ldots \ldots \ldots 145$

Kerbs v. State Veterinary Board, 154 Mich. 500, 118 N. W. $4 \ldots \ldots \ldots \ldots \ldots 50$

Keybolte v. Buffon, (Ohio) 105 N. E. $192 \ldots . . .262$

King v. Davenport, 98 Ill. $305 \quad \ldots \ldots \ldots \ldots \ldots 27$

Kirk v. Wyman, 83 S. C. 372,65 S. E. $387 \ldots \ldots 131$

Kissan $\vee$. Jones, 56 Hun, $432 \ldots \ldots \ldots \ldots \ldots 2 \pi 4$ 
Knoblauch, Ex rel., v. Warden of City Prison, 153 N. Y. Sup. $463 \ldots \ldots \ldots 13,26$ Kollenberger v. People, 9 Col. 233, 11 Pac. 101...254 Kollock, In re, 165 U. S. 526 .............. 10

Kroll v. Ernst, 34 Neb. 482, 51 N. W. 1032 ......109, 289 Kuhlman, Mrs. wid John G. v. Rucker, (U. S. Dist. Ct. New Orleans, Mch. 15, 1915.) 30 U. S. Public Health Repts. 1033 ......160

Lafitte, In re, I. R. 20 Eq. Cas. 650 .............122

Landon $\nabla$. Humphrey, 9 Conn. 209, 23 Am. Dec. 333 ............... 81

Larimer County Commrs. v. Lee, 3 Col. App. 177, 32 Pac. 841 ...........122

Lasher v. People, 183 IIl. 226,55 N. E. $663 \ldots \ldots .54$

Lathrope v. Flood, 63 Pac. 1007. Also see $135 \mathrm{Cal}$. 458, 67 Pac. 683....... 71

Lavner v. Independent Light \& Water Co., 74 Wash. 373, 133 Pac. 592..... 39

Lawson v. Conway, $37 \mathrm{~W}$. Va. 159,16 S. E. 564, 18 L. R. A. 627,38 Am. St. R. $17 \ldots \ldots \ldots \ldots 71,87$

Lawrence v. McAlvin, 109 Mass. 311 ...........133

Leach v. French, 69 Me. 359, 31 Am. Rep. 296 ...273, 274

Learned Letcher Lumber Co. v. Fowler, 109 Ala. 169, 19 So. $396 \ldots \ldots .276,279$ Leavitt v. Thompson, $52 \mathrm{~N}$.

Y. 62
Ledbetter v. State, 35 Tex. Crim. 195, 32 S. W. 903..251

Lederman, Ex rel., v. Warden of City Prison, $152 \mathrm{~N}$. Y. Sup. $977 \ldots \ldots \ldots 68$ Lewis v. Tyler, 23 Cal. 364.283 Lewiston Steam Mill Co. v. Androscoggin Water Power Co., 78 Me. 274, 4 Atl. 555 .................119

License Cases, 5 How. 504..146 Lindon v. Hooper, Cowp. 414 ...............287

Line v. Mills, 12 Ind. App. 100,39 N. E. $870 \ldots \ldots 271$

Linnendoll v. Doe, 14 Johns. 221 ..............249

Linney v. State, 6 Tex. 1, 55 Am. Dec. $756 \ldots . . .253$

Little v. Town of Lenoir, 151 N. C. 415,66 S. E. $337 \ldots \ldots \ldots \ldots \ldots 38$

Littlejohn v. Arbogast, 95 Ill. App. 505 ........ 88 Lockwood v. Bull, 1 Cow. 322 ................274

Logan v. Marquess, 53 Ind. 16 ..............288

Loomis v. Beese, 148 Wis. 647,135 N. W. $123 \ldots \ldots 260$ Lord v. Jones, 24 Me. 439..104 Louisiana v. Texas, $176 \mathrm{U}$. S. $1 \ldots \ldots \ldots \ldots 139,147$

Love v. State, 15 Tex. App. 563 ...........251, 252 Lovejoy $\mathrm{v}$. Jones, $30 \mathrm{~N}$. H. $164 \ldots \ldots \ldots \ldots 280,290$

Lowe v. Conroy, 120 Wis. 151,97 N. W. $942, \ldots$. ..........132, 145, 151

Lower v. Franks, 115 Ind. 334,17 N. E. $630 \ldots .88$ Maclin's Case, 3 Leigh, 809.233 
Mahle v. State, (Tex.) $13^{\prime}$

S. W. $999 \ldots \ldots \ldots \ldots 255$

Mahler v. Holden, 20 Ill. 363 ..............288

Maier, Ex parte, 103 Cal. 476, 37 Pac. 402, 42 Am.

St. R. 129 .........2231

Malaney v. Taft, 60 vt. 571.275

Marshall v. Bahnsen, $1 \mathrm{Ga}$. App. 485, 57 S. E. 1006.102 Maxwell v. Swigart, 48 Neb. 789,67 N. W. 789 .... 95

Mayer v. Kloepfer, 69 Atl. $182 \ldots \ldots \ldots .233,260,274$

Maynard v. Maynard, $49 \mathrm{Vt}$. 297 ...............245

Mazetti v. Armour \& Co., 75 Wash. 622, 135 Pac. 633..200 McCandless v. MeWha, 22 Harris (Pa.), 261...... 92 MicCarthy v. Wolfe, 40 Mo. $520 \ldots \ldots \ldots \ldots \ldots 278$

McCarty v. Blerins, 5 Yerg. (13 Tenn.) 195, 26 Am. Dec. 262 .......248, 249 MeClallen v. Adams, 36 Mass. 333 ......... 89

McClure . Sheek, 68 Tex. 426,4 S. W. $552 \ldots \ldots \ldots 251$

MeCorkell $\nabla$. Karhoff, 90 Iowa, $545 \ldots \ldots \ldots \ldots 245$

MeCoy v. Hock, 37 Iowa, 436 ............105, 281

McCrory v. Skinner, 2 Ohio Dec. 268 .......... 81

MeDerment v. Taft, $83 \mathrm{Vt}$. 249, 75 Atl. $276 \ldots \ldots 230$ MeDermott $\nabla$. Wisconsin, 228 U. S. $115 \ldots \ldots \ldots 146$

MrcIntyre $\nabla$. Lockridge, 28 U. C. Q. B. $204 \ldots \ldots \ldots 287$ MeKeen $\nabla$. Converse, $68 \mathrm{~N}$. H. 173,39 Atl. $435 \ldots . .288$
McKleroy 5 . Sewell, $73 \mathrm{Ga}$. 657 ............. 95

McMaster v. Merrick, 41 Mich. 505, 2 N. W. $895 . .110$ Me Mrillan v. Andrew, 50 Ill. 282 ................288

McNeil v. Davidson, 37 Ind. 336 ...............117

McPherson v. James, 69 Ill. App. $337 \ldots \ldots \ldots \ldots 288$

MeQuaid v. Ross, 85 Wis. $492 \ldots \ldots \ldots \ldots . .244$

Medlin $\nabla$. Wilkinson, 81 Ala. 147 .............280

Medsker v. Pogue, 1 Ind. App. 197, 27 N. E. $432 . .259$ Merchants' \& Mech. Sav. Bank r. Fraze, 9 Ind. App. 161 ..............244

Nerritt v. People, 169 Ill. 218,48 N. E. $325 \ldots \ldots 231$ Mesa de Mayo L. \& L. S. Co. v. Hoyt, 24 Col. App. 279, 133 Pac. 471....152, 260 Metcalf v. St. Louis, 11 Mo. 102 ...............149

Mexal v. Dearborn, 12 Gray, 336 ...............110

Nidland Valley R. R. Co. v. State, 35 Okla. 672, 130

Pac. 803 ..........179

Miller v. Burch, 32 Tex. 20836 Miller v. Horton, 152 Mass. 540,26 N. E. 100,10 L. R. A. $116 \ldots \ldots \ldots \ldots$. $27,36,85,131,145,151,154$ Miller v. State, 105 Mass. 777,63 S. E. $269 \ldots \ldots .57$ Milligan v. Wehinger, $68 \mathrm{~Pa}$.

St. $235 \ldots \ldots \ldots \ldots 261$ Mills v. N. Y. ete. Ry. Co., 2 Rob. (N. Y.) $326 \ldots \ldots .260$ Minnesota v. Barber, 136 U. S. $313 \ldots \ldots \ldots 14,200$ 
Minneapolis, St. P. \& S. S. M. R'y. Co. v. Milner, 57 Fed. 276 ............148

Mock v. Kelly, 3 Ala. 387.. 92 Morrill v. Jones, 106 U. S. $466 \ldots \ldots \ldots \ldots \ldots . . \ldots$

Morrison v. Altig, $134 \mathrm{~N}$. W. 529 ; reversed on rehearing, 157 Iowa, 265, 138 N. W. $510 \ldots \ldots \ldots .74$ Morse v. Patterson, 1 Kas. App. 577, 42 Pac. $255 \ldots .248$ Mucei v. Houghton, 89 Iowa, 608,57 N. W. $305 \ldots \ldots .71$

Mullett v. Mason, H. \& R. $779 \ldots \ldots \ldots \ldots \ldots 241$

Murdock v. Walker, 43 Ill. App. $590 \ldots \ldots$..... 83

Murgoo v. Cogswell, 1 E. D. Smith, 359 ........287

Murray v. Trinidad Nat. Bank, 5 Col. 359, 38 Pac. 615 ..............252

Murray v. Williams, $121 \mathrm{Ga}$. 63,48 S. E. $686 \ldots \ldots .94$

Musser's Exr. v. Chase, 29 Ohio, $577 \ldots$...... 87

Myers v. Holborn, 58 N. J. L. 193, 33 Atl. $383 \ldots . .80$

Nehr v. State, 35 Neb. 638, 53 N. W. 589, 17 L. R. A. $771 \ldots \ldots \ldots .98,233$

Nelson v. Harrington, 72 Wis. $591,40 \mathrm{~N}$. W. $228 \quad 77$

Nelson v. Minneapolis, 112 Minn. 16, 127 N. W. 445 ...........11, 154, 171

Nelson v. State Board of Health, 22 Ky. L. 438, 50 L. R. A. 386,57 S. W. 501 .............. 52

Neweastle v. Grubbs, 171 Ind. 482,86 N. E. $757 . .36$
New Decatur v. Berry, 90 Ala. 432 ............149

New Orleans v. Sanford, 69

S. W. 35 , (137 La. - .) .. 160

Nichols v. Duncan, 11 U.

C. Q. B. $332 \ldots \ldots \ldots \ldots 105$

Niles, Ex rel., v. Smith, 62

Fla. 93,57 So. $426 \ldots \ldots 167$

Nishimura Ekiu v. United

States, 142 U. S. $651 \ldots 62$

Norton v. Shelby Co., 118

U. S. $425 \ldots \ldots \ldots \ldots 138$

Oehler v. Levy, 234 III. 595, $85 \mathrm{~N} . \mathrm{E} .271 \ldots \ldots \ldots .33$

O'Hara v. Wells, 14 Neb. $403,15 \mathrm{~N} . \mathrm{W} .722 \ldots \ldots .75$

Ohlweiler v. Lohmanu, 82 Wis. $198,52 \mathrm{~N}$. W. $172, .274$ Orr v. Meek, 111 Ind. 40, 11 N. E. $787 \ldots . . . .994$ Orser v. Storms, 9 Cow. 687.248 Osborn v. Bank, 9 Wheat. 738 ................138

Packard v. Slack, 32 Vt. 9..242 Parker v. King, Ga. Dec. pt. 1, $131 \ldots . . \ldots . . .288$

Parker v. Mise, 27 Àla. 480, 62 Am. Dec. 776 .......233

Parks v. State, 159 Ind. 211, 64 N. E. $862 \ldots \ldots \ldots .54$ Patten v. Wiggin, $51 \mathrm{Me}$. 594, 81 Am. Dec. 593 .. 75, 92 Pearson v. Zehr, 138 Ill. 48 ...............36, 154

Peck v. Brewer, 48 IIl. 54. .279

Peck v. Hutchinson, SS Iowa, 320,55 N. W. $511 \ldots . .76,82$ Peer v. Ryan, 54 Mich. 224, 19 N. W. $961 \ldots . . .259$

Peirce v. New Hampshire, 5 How. $504 \ldots . . . . .146$ 
Pepke v. Grace Hospital, 130 Mich. 493, 90 N. W. 278 77

People v. Apflebaum, 251 Ill. 18, 95 N. E. $995 \ldots 52$ People v. Arensberg, $105 \mathrm{~N}$. Y. 123,11 N. E. $277 . \ldots .197$ People v. Buffalo Fish Co., 164 N. Y. 93, 58 N. E. $34 \ldots \ldots \ldots \ldots . .232$

People v. Frudenberg, 140

N. Y. Sup. $17 \ldots \ldots \ldots 172$

People v. Grace Hospital, 130 Nich. 493, 90 N. W. 278 77

People v. Holtz, 92 Ill. 426. 54 People v. Roff, 3 Park. Crim. Cas. 216 ............149

People v. Tait, 261 Ill. 197, 103 N. E. 750 .........144

People v. Umlauf, 88 Mich. 274, 50 N. W. $251 \ldots .247$

People v. William Henning Co., 260 Ill. 554, 103 N. E. $530 \quad \ldots \ldots \ldots \ldots 197$

People ex rel. See under first name.

Perham v. Coney, 117 Mass. $102 \ldots \ldots \ldots \ldots \ldots .273$

Perionowsky v. Freeman, 4 Foster \& Finlason, 977... 79 Phelps v. Racey, 60 N. Y. 10 ..............231

Pierson v. Hoag, 47 Barb. 243 .............120

Pike r. Honsinger, 155 N. Y. 201 79

Pinkham v. Libbey, 93 Me. 575, 45 Atl. 823,49 L. R. A. 693 .257

Piper v. Menifee, 12 B. Mon. 465 ............... 85

Pisani, Ex rel., v. McKelway, 148 N. Y. Sup. 818. 57
Pitcheock v. Donnahoo, 70 Ark. 68,66 S. W. $145 \ldots .258$ Poag v. State, 40 Tex. 151. .252 Poage v. State, 43 Tex. 454.251 Poindexter r. Greenhow, 114 U. S. $270 \ldots \ldots \ldots \ldots 138$ Polinsky v. People, $73 \mathrm{~N}$. Y. 65 .............172 Pollak v. Gregory, 9 Bosw. 116 ..............121

Porges v. Jacobs, (Ore.) 147 Pac. 396 ..........36, 38

Potter v. Virgil, 67 Barb. 578 ............. 72

Powers v. Botts, 58 Mo.

App. 1 ......109, 281, 289 Prevosty v. Nichols, 11 Mart.

(O. S.) $21 \ldots \ldots \ldots .93$

Price v. Pepper, 76 Ky. 42.257

Puckett v. Alexander, 102 N. C. 95,8 S. E. 767,3 L. R. A. $43 \ldots \ldots \ldots .94$ Putnam v. Wyley, 8 Johns. 432, 5 Am. Dec. 346.248, 249

Rankin v. Shepherdson, 89 Ill. $445 \quad \ldots \ldots \ldots .280$ Rasmussen v. State of Idaho, 181 U. S. $198 \ldots \ldots \ldots 150$ Rayl r. Kreilich, 74 Mo. App. $246 \ldots \ldots \ldots \ldots 27 \mathrm{~s}$

Reese v. State, 43 Tex. Cr. 539, 67 S. W. $325 \ldots .251$ Reetz v. Michigan, 188 U. S. $505 \quad \ldots \ldots \ldots \ldots 46$ Reg. r. Henson, 1 Dears. 24 $.240,260$

Ressequie v. Byers, 52 Wis. $650 \quad \ldots \ldots \ldots \ldots \ldots .68$

Reynolds v. Smith, 148 Iowa, 264, 127 N. W. $192 \ldots .79$ Rice v. Underwood, $27 \mathrm{Mo.}$

551 ............2s8 
Rigbers v. City of Atlanta, 7 Ga. App. 411, 66 S. E. 991

Ritchey v. West, 23 Ill. 385. 73 Robbins v. Magoon \& Kimball Co., 153 N. W. 13 $.260,261,274$

R'obertson v. Brown, 1 U. C. Q. B. $345 \ldots \ldots \ldots \ldots 271$ Robinson v. Rohr, 73 Wis. 436

Roelker, In re, 1 Sprague, 276 ...............122

Rogers v. State, 9 Tex. App. 43 .254

Rosenheim v. American Insurance Co., 33 Mo. 230..118

Rosswell v. Cottom, $31 \mathrm{~Pa}$. St. $525 \ldots \ldots \ldots \ldots 265$

R'othwell v. Milner, 8 Manitoba, $472 \ldots \ldots \ldots .241$

Royal Col. of Vet. Surgeons v. Collinson, 77 L. J. K. B. 689 , (1908) 2 K. B. $248 . .67$ Royal Col. of Vet. Surgeons v. Groves, 57 J. P. 505 .. 67 Royal Col. of Vet. Surgeons v. Robinson, 61 I. J. C. 146, (1892) 1 Q. B. $557 . .66$

Saint Louis v. Jud, 236 Mo. 1, 139 S. W. $441 \ldots \ldots .197$ Saint Louis v. Polinsky, 190 Mo. 516.............197

Salem v. Eastern R. Co., 98 Mass. $431 . . . . \ldots \ldots \ldots 151$

Salzenstein v. Mavis, $91 \mathrm{Ill}$. $391 . \ldots \ldots \ldots \ldots 5,148,149$

Sanford v. Kimball, $106 \mathrm{Me}$. 355,76 Atl. 890 . (Reporter gives name incorrectly as "Sanborn.") ..278 Sawyer v. Gerrish, 70 Me. 254, 25 Am. Rep. 323, Am.
Eng. Enc. of Law, 349 .............248, 258

Scarfe v. Morgan, 4 M. \& W. $270 \ldots \ldots \ldots \ldots \ldots$. 258

Schaar v. Comforth (Minn.), 151 N. W. $275 \ldots \ldots \ldots 261$

Schroeder v. Faires, 49 Mo. 470 ...............260

Scott $\nabla$. Hogan, 72 Iowa, 614, 34 N. W. $444 \ldots . . .259$

Scott $\nabla$. Mercer, 63 Iowa, $325 \quad \ldots \ldots \ldots \ldots \ldots \ldots 285$

Scott v. Mercer, 98 Iowa, 258, 67 N. W. 108....285

Scott . Renick, 1 B. Mon.

63 ...............244

Seale v. McCarty, 148 Cal.

61, 82 Pac. $845 \ldots \ldots . .284$ Seavey v. Preble, 64 Mo. 120 ................151

Seigle v. Bromley, 22 Col. App. 189, 124 Pac. 191... 32 Sentell v. New Orleans, etc., R. Co., 166 U. S. $698 . .98,230$ Seymour v. United States, 2 App. D. C. $240 \ldots \ldots \ldots 133$ Sheridan v. Bean, 8 Metc. 284 .............260

Sherrod v. Langdon, 21 Iowa, 518 ..............242

Shields v. Dodge, 14 Lea, 356 ...............285

Shipman v. State Live Stock Commrs., 115 Mich. 488..151 Shivers v. Newton, 45 N. J. L. $469 \ldots \ldots \ldots \ldots 154,173$ Sholl, Ex rel., v. Dunean, 162 Ala. 196, 50 So. $265 . \ldots 145$ Siglin v. Coos Bay R. \& E. R. \& N. Co., 35 Ore. 79, 56 Pac. $1011 \ldots . . \ldots \ldots 266$ Sims v. Bradford, 80 Tenn. 434 .254 
Simpson v. Shepard, 33 (U.

S.) Sup. Ct. 729, 230 U.

S. $352 \ldots \ldots \ldots \ldots \ldots 148$

Sisk v. Crump, 112 Ind. 504,

14 N. E. $381 \ldots \ldots \ldots 265$

Skinner v. Caughey, 64 Minn.

375,67 N. W. $203 \ldots . .284$

Slaughter v. State, 7 Tex.

App. $123 . . . \ldots \ldots \ldots .253$

Small v. Howard, 128 Mass.

131 .............. 76

Smith v. Green, 1 C. P. D.

$92 \ldots \ldots \ldots \ldots \ldots 241$

Smith v. Justice, 13 Wis. $600 \quad \ldots . \ldots \ldots . .244$

Smith $\nabla$. Lowe, 121 Fed. 753 ...............150

Smith v. Robertson, $106 \mathrm{Ky}$. 472,50 S. W. $852,20 \mathrm{Ky}$. Law, 1959, 45 L. R. A. $510 \quad \ldots \ldots \ldots \ldots \ldots 255$

Smith v. St. Louis \& S. W.

R. Co., 181 U. S. $248 . .14,150$

Smith r. State, 155 Ind. 611, 58 N. E. 1044, 51 L. R'. A. 404 ..............231

Smothers v. Hanks, 34 Iowa, 286, 11 Am. Rep. 141... 76

Somme, In re, $136 \mathrm{~N}$. Y. Sup. 57 .............. 51

Sopher v. State, 169 Ind. 177,81 N. E. 913 ....... 31

Southern Ry. Co. v. Poetker, 46 Ind. App. 295, $91 \mathrm{~N}$. E. $610 \ldots \ldots \ldots \ldots 38$ Spa v. Ely, 8 Hun, $255 \ldots 84$ Spinney, Ex parte, $10 \mathrm{Nev}$. 323 46

Spooner v. Manchester, 133

Mass. 270..........2 280

Spriggs, Ex rel., v. Robinson, 253 Mo. 271, 161 S.

w. $1169 \ldots \ldots \ldots \ldots 60$
Stanberry v. Dickerson, 35

Iowa, $493 \ldots \ldots \ldots \ldots 117$

Stanfield v. Stiltz, 93 Ind. 249 .............247

Starrett v. Miley, $79 \mathrm{Ill}$.

App. $658 \ldots \ldots \ldots \ldots .96$

Staples v. Steed, 167 Ala.

241,52 So. $646 \ldots . . .83,114$

State v. Butts, 3 S. Dak. 577,

19 L. R. A. 725,54 N. W.

603 ...............139

State v. Call, 121 N. C. 643 ,

28 S. E. $517 \ldots \ldots \ldots$..... 49

State v. Cardelli, 19 Nev. 319,

10 Pac. 433.......251, 252

State v. Collingsworth Sewerage Co., $85 \mathrm{~N}$. J. L. 567, 89 Atl. 525....... 40

State v. Crescent Creamery Co., 83 Minn. 284, 54 L.

R. A. 466,86 N. W. $107 . .167$

State v. Davis, 24 N. C. 153.253

State v. Duckworth, 5 Ida.

642, 51 Pac. 456......150

State v. Fox, 79 Md. $514 \ldots 240$ State v. Gregory, 83 Mo. 12352 State v. Hathaway, 115 Mo.

36, 21 S. W. $1081 \ldots . .46,49$ State v. Haws, 41 Tex. 161.254

State v. Hutchinson Ice

Cream Co., 147 N. W. 195.166 State v. K. C. M. \& B. Co.

(Ark.), 174 S. W. 248... 12

State v. Lutz, 136 Mo. 633,

38 S. W. $323 \ldots \ldots \ldots .52$

State v. Matthews, 20 Mo.

55 .............253

State v. Milwaukee, 140 Wis.

38,121 N. W. $658 \ldots \ldots .168$

State v. Niles, 78 Vt. 266,

62 Atl. 795, 112 Am. St.

R. $917 \ldots \ldots \ldots \ldots 231$

State v. Rodman, 58 Minn.

393, 59 N. W. $1098 \ldots .231$ 
State v. St. P. M. \& O. R. Co., 40 Minn. 267, $40 \mathrm{~N}$.

W. $1047 \ldots \ldots \ldots \ldots 147$

State v. Schmuck, 77 Ohio, 438,83 N. E. $797 \ldots . . .173$

State v. State Medical Ex. Bd., 32 Minn. 324, $20 \mathrm{~N}$.

W. $238 \ldots \ldots \ldots \ldots 49,60$

State v. Swayze, 11 Ore. 357, 3 Pac. 574........254 State v. Teipner, 36 Minn. 535, 32 Minn. 678......122

State v. Vandersluis, 42 Minn. $129 \ldots \ldots \ldots \ldots .54$

State $\mathrm{r}$. Van Doran, $109 \mathrm{~N}$. C. 864,14 S. E. $32 \ldots \ldots 54$

State v. Yopp, 97 N. C. 477 , 2 S. E. $689 \ldots \ldots .131,134$

State Board of Health v. Greenville, 86 Ohio, 1, 98 N. E. $1019 \ldots \ldots \ldots 38,149$

State Medical Board v. McCrary, 95 Ark. 511, $130 \mathrm{~S}$. W. $544 \ldots \ldots \ldots \ldots .60$

Sternberger v. Cape Fear \& Y. V. R. R. Co., 29 S.

C. $510 \ldots \ldots \ldots \ldots \ldots 147$

Stevens v. Bradley, 89 Iowa, 174 ...............241

Stewart v. Ball, 33 Mo. 154248

Stewart v. Davis, 31 Ark. 518 .275

Stewart v. Hunter, 16 Ore. 62, 16 Pac. 876, 8 Am. St. R. $267 \ldots \ldots \ldots \ldots .251$

Sturgeon v. Merritt, 49 Mo.

App. $160 \ldots \ldots \ldots \ldots 255$

Sturtevant v. Merrill, $33 \mathrm{Me}$. 62 .265

Styles v. Tyler, 64 Conn. 432,

30 Atl. $165 \ldots \ldots \ldots 87,92$

Summers v. State, 5 Tex.

App. $365 \ldots \ldots \ldots .121,122$
Sumner v. Beeler, 50 Ind. 341 ...............138

Tabor v. Salisbury, 3 Col. App. 335, 33 Pac. 190...286

Taggard v. Buckmore, 42 Me. $77 \ldots \ldots \ldots \ldots 282$

Talbot v. Magee, 59 Mo. App. $347 . . . . . . . . .249$

Tandy v. Elmore Cooper L. S. Com. Co., 113 Mo. App. 409, 87 S. W. $614 \ldots \ldots 283$ Taylor v. Adair Co., $119 \mathrm{Ky}$. 374 ................139

Taylor v. Gardiner, 8 Manitoba, $310 \ldots \ldots \ldots \ldots 244$

Taylor v. State, 35 Tex. 496 ............254

Teft v. Wileox, 6 Kas. 46 ...............76, 92

Thomas v. Ingham Co. Supervisors, 142 Mich. 319, 105 N. W. $771 \ldots \ldots . .145$

Thomas v. State Board of Health, 72 W. Va. 776, 79 S. E. $725 \ldots \ldots \ldots \ldots 57$

Thompson v. Harlow, $31 \mathrm{Ga}$. $348 \ldots \ldots \ldots \ldots 271,273$ Thompson v. Hazen, $25 \mathrm{Me}$. $104 \ldots \ldots \ldots \ldots \ldots .49$

Thompson v. State, 26 Tex.

App. $466 \ldots \ldots \ldots \ldots 250$

Thompson v. Von Lear, 77 Ark. $506 \ldots \ldots \ldots \ldots 61$ Thurlow v. Massachusetts, 5 How. $504 \ldots \ldots \ldots \ldots 146$ Tish v. Welker, 7 Ohio N. P. 472 .............. 81

Tomer v. Aikin, 126 Iowa, 114,101 N. W. $769 . \ldots .80$ Towle v. R'aymond, 58 N. H. 64 ...............285

Tucker v. Constable, 16 Ore. 407, 19 Pac. 13........259 
Tuttle v. Dennis, 58 Hun, 35,11 N. Y. Sup. $600 \ldots 258$

Underwood v. Birdsell, 6 Mont. 142, 9 Pac. $992 \ldots . .284$ Underwood r. Scott, 43 Kas. 714, 23 Pac. 942,...... 94 United States v. Eaton, 144 U. S. $677 \ldots \ldots \ldots \ldots .10$

United States v. Howe, 12

Cent. L. J. 193 . . . . ...122

United States v. Lee, $106 \mathrm{U}$.

S. $196 \ldots \ldots \ldots \ldots \ldots 138$

Uren v. Walsh, 57 Wis. $98 . .133$

Vantreese v. MicGee, 26 Ind. App. 525, 60 N. E. $318 . .232$

Wales v. Ford, 8 N. J. L. $267 \ldots \ldots \ldots \ldots \ldots 265$

Walker v. Cook, 33 Ill. App. $561 \ldots \ldots \ldots \ldots \ldots 116$

Walker v. Hoisington, 43

Vt. $608 \ldots \ldots \ldots \ldots .243$

Ward จ. Brown, 64 Ill. 307.265

Ward v. Hobbs, 4 App. Cas.

13 ..............240

Warring v. Cripps, 23 Wis.

$460 \quad \ldots \ldots \ldots \ldots .287$

Washburn v. Cuddihy, 8

Gray, $430 \ldots \ldots \ldots 243$

Watson v. Denton, 7 C. \& P. $85 \ldots \ldots \ldots \ldots \ldots 242$

Watson v. Maryland, 105

Md. 650, 66 Atl. $635 . . .446$

Waye v. Thompson, 15 L. R.

Q. B. D. $342 \ldots \ldots \ldots 151$

Webb v. Page, 1 C. \& P. 23.122

Weber v. Hartman, 7 Col.

13, 1 Pac. $230 \ldots . . . . .288$

Weber v. Whetstone, $53 \mathrm{Neb}$. 371,73 N. W. $695 \ldots .$.
Weide v. Thiel, 9 Ill. App. 223 ...............264

Weigand $\checkmark$. District of Columbia, 22 App. D. C. 559 ..............167

Weinsberg v. St. Louis Cordage Co., 135 Mo. App. 553, 116 S. W. $416 \ldots \ldots \ldots .96$

Wells v. Littlefield, 59 Tex.

$556 \quad \ldots \ldots \ldots \ldots \ldots 250$

Wells v. State (Tex.), $13 \mathrm{~S}$.

W. $889 \ldots \ldots \ldots \ldots .255$

Wells v. World's Dispensary

Med. Assn., 9 N. Y. 452 . 76

West v. Martin, 31 Mo. 375.76

Whidden v. Cheever, $69 \mathrm{~N}$.

H. 142, 44 Atl. 908.....151

White v. Carroll, 42 N. Y.

161 .............. 52

White v. Mastin, 38 Ala. 14799

White $\nabla$. Stelloh, 74 Wis.

$435 \quad \ldots \ldots \ldots \ldots \ldots 244$

Whitesell v. Hill, $66 \mathrm{~N}$. W.

$894 \ldots \ldots \ldots \ldots \ldots .76,95$

Whitlock v. Heard, 13 Ala.

776, 48 Am. Dec. 73....286

Whitney v. Taylor, 54 Barb.

$536 \quad \ldots \ldots \ldots \ldots \ldots 243$

Willard v. Whinfield, 2 Kas.

App. 53, 43 Pac. 314... $.109,286,289$

Williams v. Frazier, 41 How.

Pr. (N. Y.) $428 \ldots \ldots .279$

Williams v. Gilman, $71 \mathrm{Me}$.

21 .............. 83

Williams v. People, 121 Ill.

84 .............. 54

Williams v. Poppleton, 3

Ore. $139 . \ldots \ldots \ldots \ldots .75$

Williams v. State Board of Med. Exrs., 120 Minn. 313, 139 N. W. $500 \ldots \ldots \ldots .57$

Wills v. Barrister, 36 vt. $220 \quad \ldots \ldots \ldots \ldots . .283$ 
Wilson $\nabla$. Alabama, G. S. Ry. Co., 77 Miss. 714, 28 So. 567 ....

Wilson v. Finney, 13 Johns. 358

Wilson v. McLaughlin, 107 Mass. $587 \ldots . . .2 .287$

Winn v. Morris, 94 Ga. 452.242

Winner v. Lathrop, 67 Hun, 511 ............... 87

Winsor v. Lombard, 18 Pick. 57 .................200

Wise $\nabla$. State Veterinary Board, 138 Mich. 428, 101 N. W. $562 \ldots \ldots \ldots \ldots .49$

Wolf r. Board of Med. Exrs., 109 Minn. 360, 123 N. W. $1074 \ldots \ldots .6 .62$ Wolf r. Wall, 40 Ohio, 111. 81 Wolseheid v. Thome, 76 Mich. 265, 43 N. W. 12..271

Wong Wai v. Williamson, 103 Fed. 1...........139
Wood v. Ash (Eng.), Owen, 139 ...............248 Woodard v. Myers, 15 Ind. App. 42,43 N. E. $573 \ldots 286$ Woolf v. Chalker, 31 Conn. 121, 81 Am. Dec. $175 \ldots 233$ Wright $v$. Richmond, 21 Mo.

App. $76 \ldots \ldots \ldots \ldots 288$

Wright v. Sherman, 3 S. Dak. 290, 52 N. W. 1093, 17 L. R. A. $792 \ldots . . . .286$ Wright $\nabla$. Waddell, 89 Iowa, 350,56 N. W. $650, \ldots$. ..........109, 285, 289

Yates จ. Milwaukee, $10 \mathrm{Wall}$. 497 ............... 30 Yearsley v. Gray, $140 \mathrm{~Pa}$. St. 238,21 Atl. $318 \ldots . .281$ Yoakum v. State, 21 Tex. App. 260, 17 S. W. 254..254

Zanetta v. Bolles, $80 \mathrm{Vt}$. 345, 67 Atl. 818.......230 


\section{INDEX}

Actinomycosis, Meat condemned for............... 191

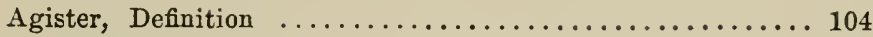

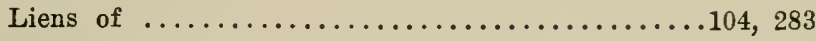

Alienum non laedat ........................... 60

Basis of idea of nuisance ................... 23

Animals-

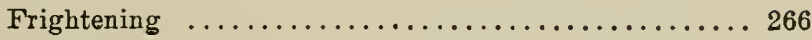

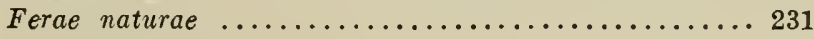

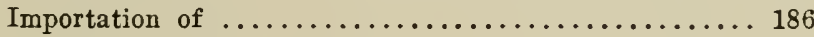

From North America ................ 187

Injuries-

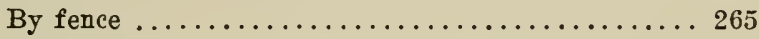

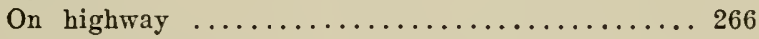

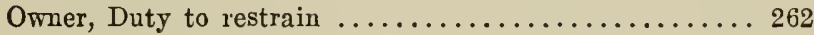

Liability of .................151, 156, 164, 260 Ownership of-

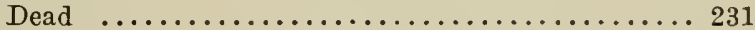

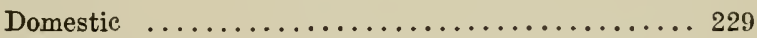

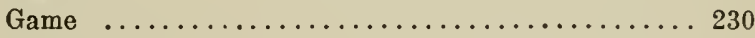

Obtained by capture ................... 234

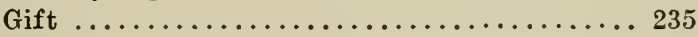

Increase $\ldots \ldots \ldots \ldots \ldots \ldots \ldots \ldots \ldots . . .247-249$

Inheritance $\ldots \ldots \ldots \ldots \ldots \ldots \ldots \ldots \ldots . \ldots 234$

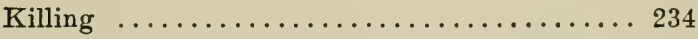

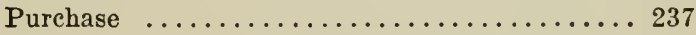

Proof of ......................... 249

Marks and brands, see Brands.

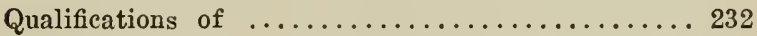

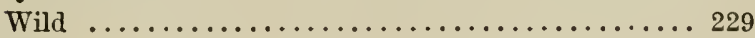

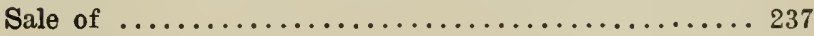

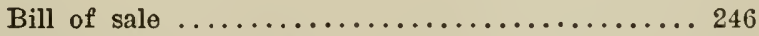

Warranty of character .................. 244

Warranty of soundness ...................239

Transportation of ......................

With infectious disease, Keeping of, not per se culpable 
Anthrax, Animal must be destroyed.............. 190

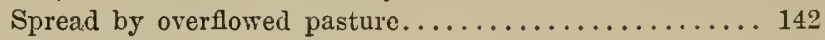

Appeals, Courts of $\ldots \ldots \ldots \ldots \ldots \ldots \ldots \ldots \ldots \ldots \ldots \ldots \ldots$

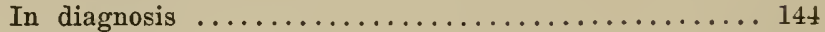

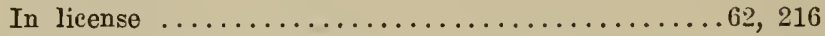

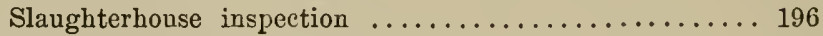

Arbitrary acts illegal ........................ 13

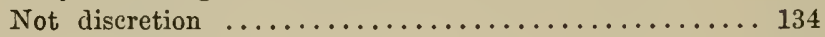

Slaughterhouse inspection $\ldots \ldots \ldots \ldots \ldots \ldots \ldots \ldots \ldots \ldots$

Bacillus mallei ......................119, 145, 241 Bailee-

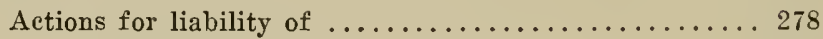

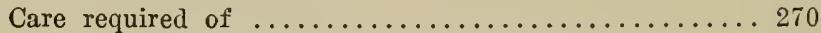

Ordinary care, What is $\ldots \ldots \ldots \ldots \ldots \ldots \ldots .272$

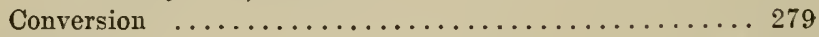

Definition ....................... 105, 268

Duty to return animal........105, 106, 269, 272, 276, 279

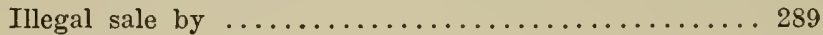

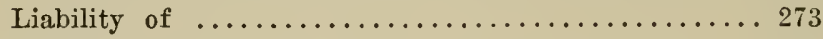

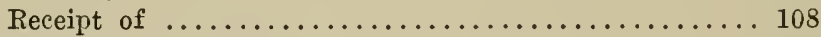

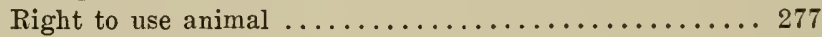

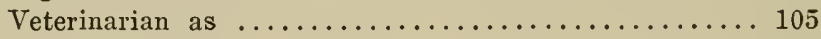

Bailment, A contract ................... 105, 108, 269

Definition ............................... 268

Distinguished from sale or gift.............. 276

Implies knowledge of bailee ................ 270

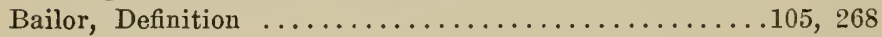

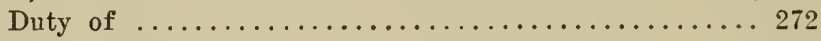

May not be owner ........................ 269

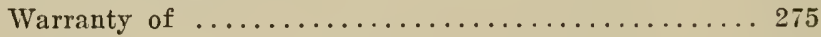

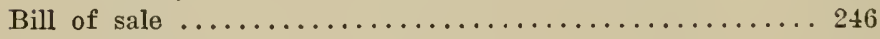

Biologic products--

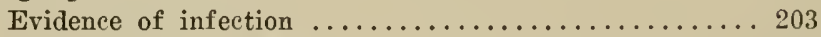

Governmental supervision .................201-205

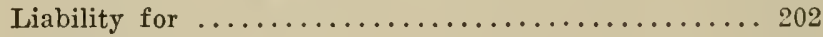

Necessity for care .................. 202

Bonham's case .......................... 45

Brands-

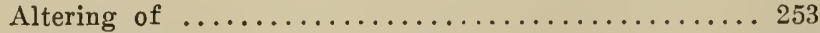

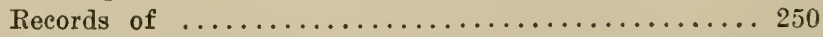

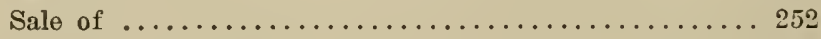

Unrecorded, Evidence of ownership............. 251

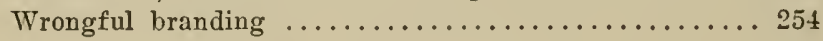


Breeding, see Stallion.

Butchers, Reports by $\ldots \ldots \ldots \ldots \ldots \ldots \ldots \ldots \ldots \ldots . \ldots, 253$

Caveat emptor ................................... 241

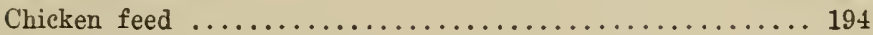

City-

Jurisdiction in sanitation.............6, 134, 146, 149

Ordinances ........................ 11, 137

Regulating milk ...................... 137

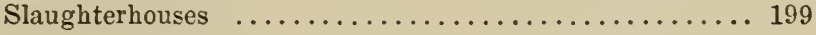

Common law, Defined ....................... 4

Compensation for professional service of reterinarian-

Actions for recorery of $\ldots \ldots \ldots \ldots \ldots \ldots \ldots \ldots \ldots \ldots \ldots \ldots \ldots$

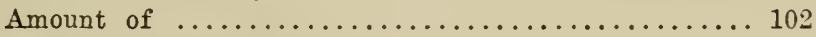

Effect of malpractice on ................. 95

Liens for, see Liens.

Of expert witness ....................... 120-125

Use of mails in collection.................... 103

Who liable for.................. $0,91,95,102$

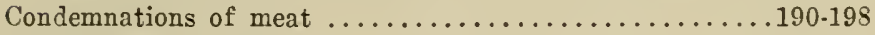

Constitutions defined $\ldots \ldots \ldots \ldots \ldots \ldots \ldots \ldots \ldots \ldots \ldots \ldots$

Conrersion, see Bailment.

Delegation of anthority ..................... 139

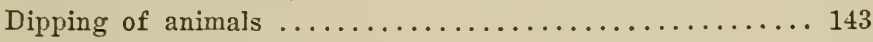

Diseretionary duties ......................... 15

Cannot be delegated .......................... 139

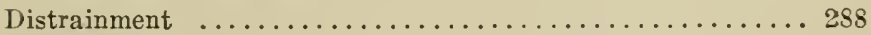

Dirision of powers ......................... 7

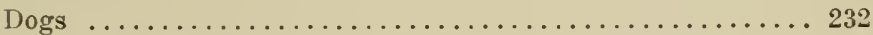

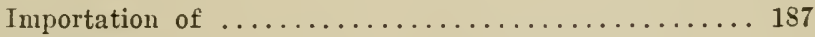

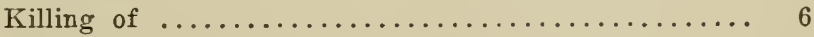

Liability for service to..................... 97.98

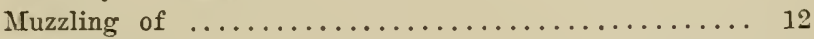

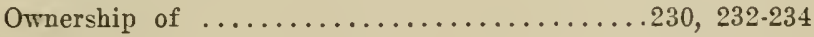

Owner's liability for injury by ................ 233

Dourine-

Animal not to be transported ................ 192

Communicated by flies .................. 142,183

Liability in breeding ................. 256,259

Driving from range, When criminal, or not.......... 254

Due process of law, Definition.................. 27

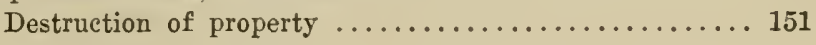


Estrays-

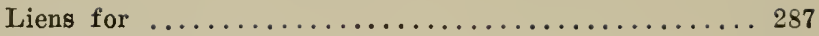

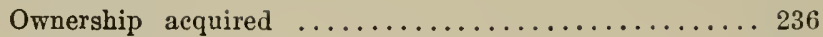

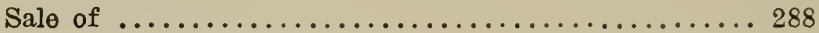

Evidence (See also Witness)-

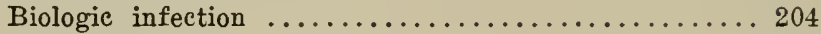

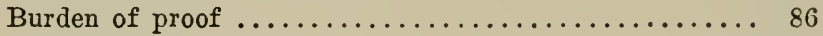

License ........................ 113

Ownership of animals . .................249-254

Right to practice ........................ 113

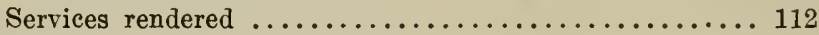

Executive-

American system unsatisfactory $\ldots \ldots \ldots \ldots \ldots \ldots \ldots .206$

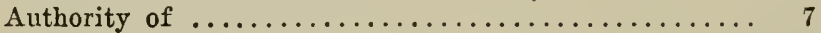

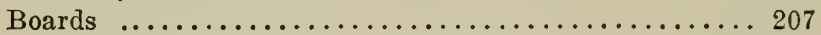

Health department ......................218-225

Orders, Force of $\ldots \ldots \ldots \ldots \ldots \ldots \ldots \ldots \ldots \ldots \ldots \ldots$

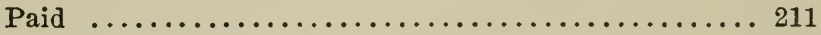

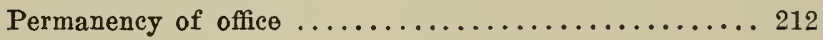

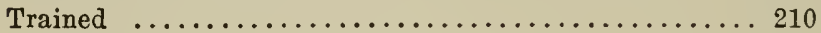

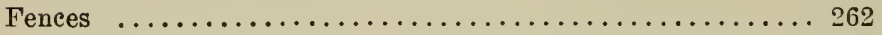

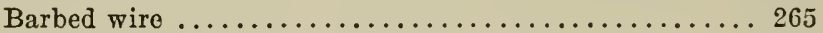

Fly, a nuisance per se ............................35

Foot and mouth disease-

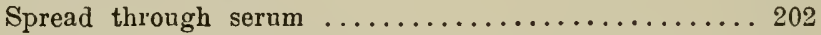

Transportation prohibited $\ldots \ldots \ldots \ldots \ldots \ldots \ldots \ldots \ldots \ldots \ldots \ldots$

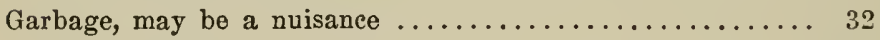

Gelding, Death after ....................... 83

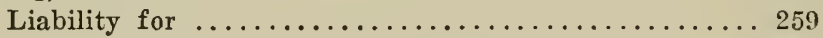

Lack of, not unsoundness .................. 243

General disease, condemnations of meat for............ 191 Glanders, Animal infected with-

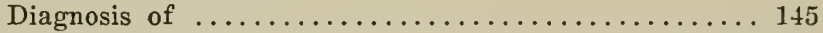

Killed for, Liability .................... 131

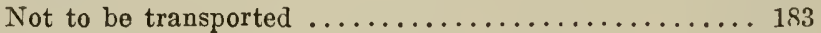

Sale of $\ldots \ldots \ldots \ldots \ldots \ldots \ldots \ldots \ldots \ldots \ldots \ldots \ldots \ldots 239.241$

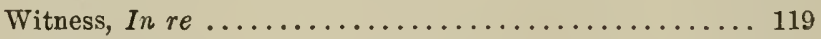

Governmental control ......................... et seq.

Appointment of veterinarians in B. A. I. ......... 176

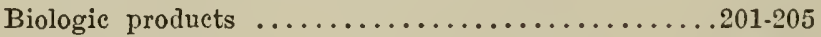

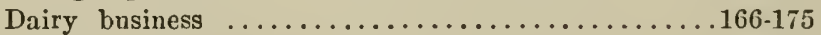

Practice of veterinarian ................... $43-68$ 
Governmental control (continued)-

Quarantine .............................. 162

Slaughterhouses and meat industry ............188-198

Antemortem examination ................. 189

Postmortem examination .................1\&9-198

Transportation of live stock.............. 175-188

Liability of Department of Agriculture......... 181

Protection of inspectors ................ 180

Health department-

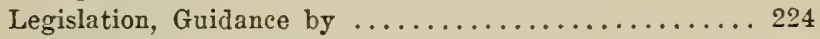

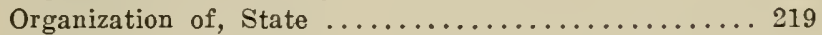

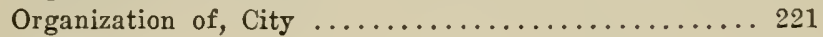

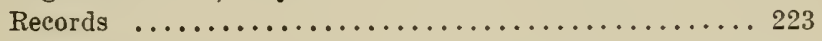

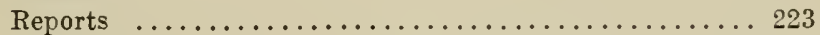

Veterinarians in ......................218-221 Hog-

Infection of cholera serum............65, 202, 203

Inspection for slaughter . . . . . . . . . . . . 191

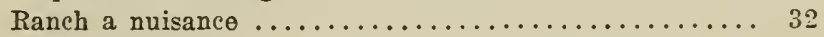

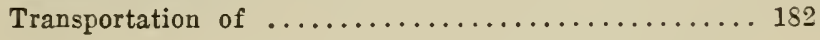

Judiciary-

Authority, General $\ldots \ldots \ldots \ldots \ldots \ldots \ldots \ldots \ldots \ldots \ldots \ldots \ldots \ldots \ldots \ldots \ldots \ldots$

Authority over legislation .................. 12

Decisions ........................... 17

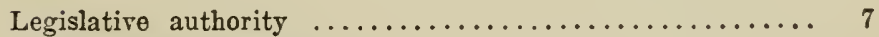

Of health department ..................... 224 Liability-

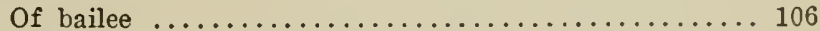

Of one calling veterinarian $\ldots \ldots \ldots \ldots \ldots \ldots \ldots, 91$

Of owners of animals, general................ 260

For spread of infectious disease.........151, 156-164

Of owners of stallions ....................... 259

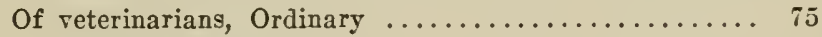

Accidents .......................... 84

Acts of assistants ................. is

Death after gelding .................... 83

Injury in throwing animal................. 83

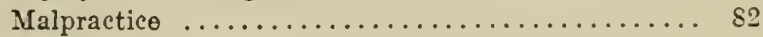

Partnership ......................... 80

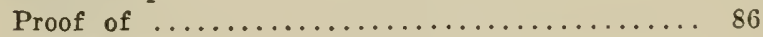

Special cases of $\ldots \ldots \ldots \ldots \ldots \ldots \ldots \ldots \ldots, 85$ 
Liability (continued) -

Of veterinarians (continued) -

Spread of infection ..................... 205

Survival of action..................... 81

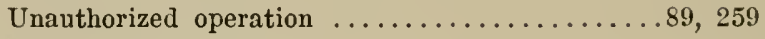

Under enactments .................... 89

Defense in acticns-

Contributory negligence $\ldots \ldots \ldots \ldots \ldots \ldots$........ 88

Illegal practice ..................... 88

Payment of fees .................. 88

License-

Board, Appointment of $\ldots \ldots \ldots \ldots \ldots \ldots \ldots \ldots$. 214

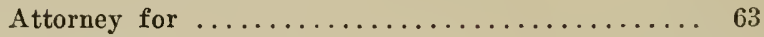

Dairy business ..........................

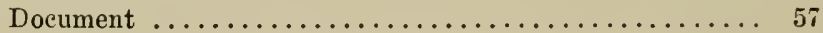

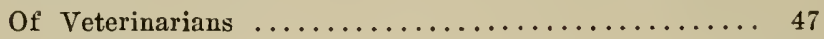

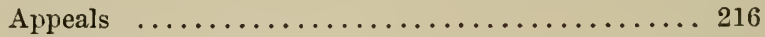

Rerocation ....................... 59

Unlicensed, no rights.................. 94

Liens-

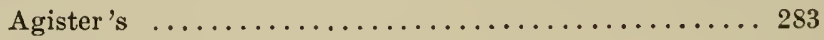

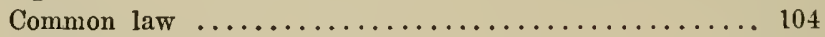

Contract ............................. 107

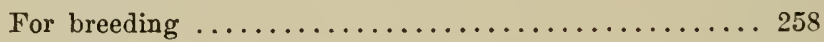

For estrays and trespassing animals............. 287

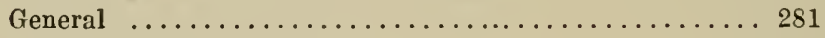

Lost cannot be revired ....................... 290

Not a right to sell ....................... 110

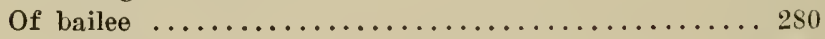

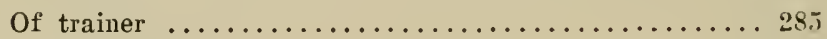

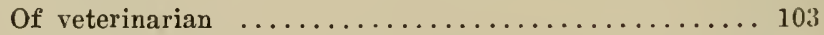

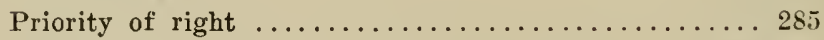

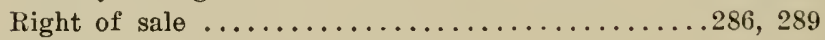

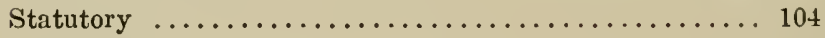

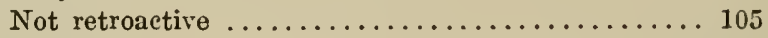

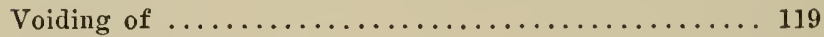

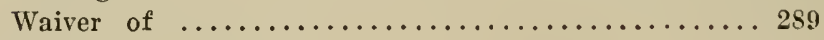

Lip and Leg Uleeration-

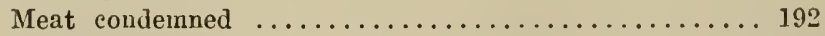

Transportation $\ldots \ldots \ldots \ldots \ldots \ldots \ldots \ldots \ldots \ldots \ldots \ldots \ldots \ldots \ldots \ldots \ldots \ldots$ Livery-

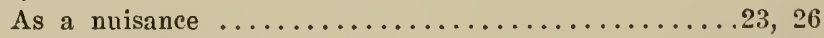

Keeper as bailce or bailor.................... 268

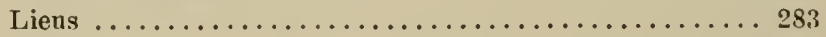


Manure pile, when a nuisance................... 33

Ministerial duties ........................ 15

Iilk-

Authority of national, state and city officers........ 135

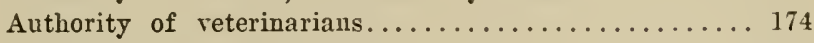

Bailed cow should be milked..................272

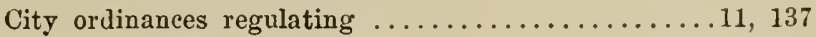

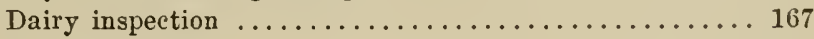

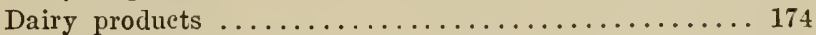

Destroy, Right of officers................. 173

Need of state regulation................... 217

Quality of .......................... 166

Tuberculin test $\ldots \ldots \ldots \ldots \ldots \ldots \ldots \ldots \ldots \ldots \ldots \ldots, 110$

Nation; Jurisdiction of, in sanitation.............. 6

Nuisance-

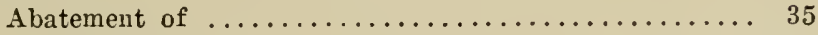

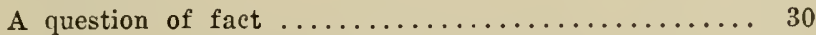

Authority for abatement, not for construction........ 39

Change in legal standard of ................. 33

City must not commit ...................... 38

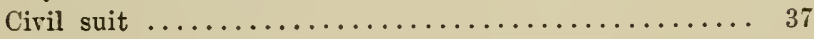

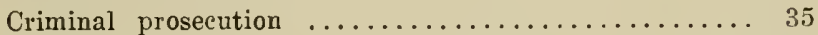

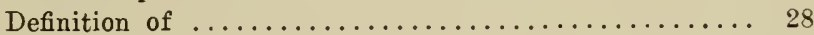

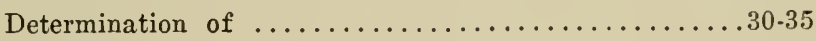

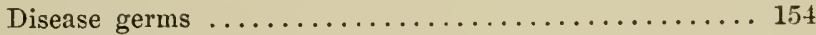

Flies, nuisance per se .................... 33

General treatment of $\ldots \ldots \ldots \ldots \ldots \ldots \ldots \ldots \ldots .35$

Lirery stables ........................... 30

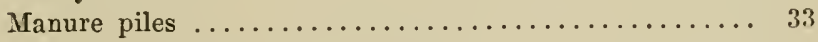

May be enjoined before occurring............ 23

Measure of damages ....................... 38

Per se, in esse, and in posse................. 29

Prirate or public ....................... 28

Public nuisance per se unlawful............... 31

Officer (Also see Quarantine)-

Arbitrary actions prohibited................ 134

Authority limited by jurisdiction............. 134

Authority determined by legislation............ 137

Invalid act no defense for................. 137

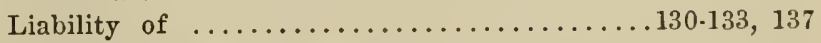

Of state and nation at same time............. 159

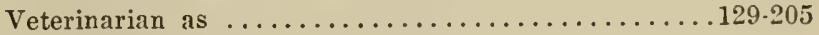

With discretion eannot be coerced.............. 133 
Police power-

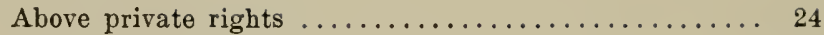

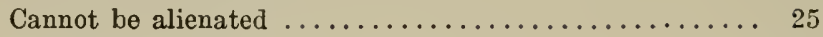

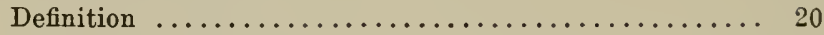

Destruction of property under..............25, 151

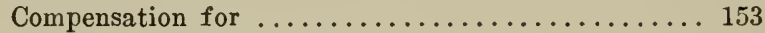

Appraisement of property .............. 157

National power indirect .................. 22

Resides in the states $\ldots \ldots \ldots \ldots \ldots \ldots \ldots \ldots \ldots \ldots, 21$

Property-

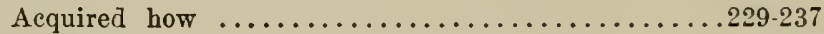

Destruction of ......................... 151

No right when acquired or used contrary to law.......26

Taken under eminent domain .................. 1

Taken under police power $\ldots \ldots \ldots \ldots \ldots \ldots \ldots \ldots \ldots \ldots \ldots \ldots, 25$

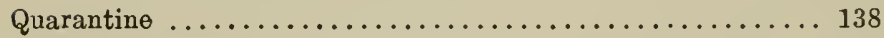

Authority cannot be delegated............... 139

Diagnosis for ........................... 144

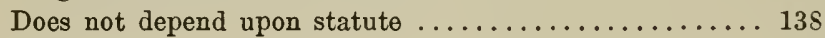

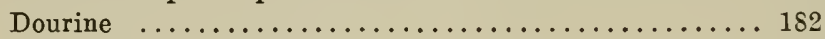

Foot and mouth disease .................... 184

Glanders .................................. 183

Hog cholera and swine plague................. 182

Jurisdiction in .........................146-149

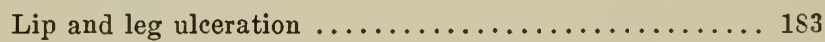

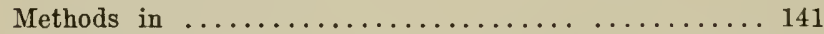

Regulations of B. A. I. .................. 176-188

Regulations should be published............... 143

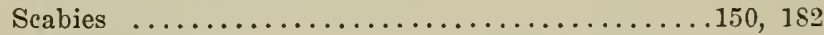

Texas eattle fever ....................... 177

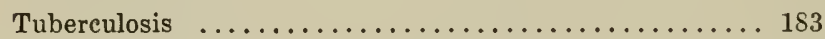

Versus commerce ......................... 149

What diseases subject to $\ldots \ldots \ldots \ldots \ldots \ldots \ldots \ldots$

Rats, a nuisance per se ........................... Records of-

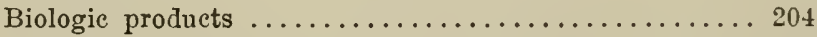

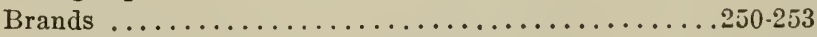

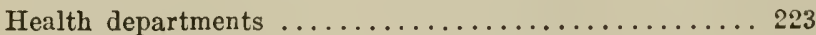

Services rendered ........................ 112

Registration of veterinarians................... 50

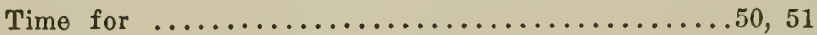

Respondeat superior $\ldots \ldots \ldots \ldots \ldots \ldots \ldots \ldots \ldots \ldots \ldots \ldots \ldots$ 
Scabies-

Liability for $\ldots \ldots \ldots \ldots \ldots \ldots \ldots \ldots . \ldots \ldots, 101,152,260$

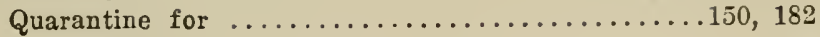

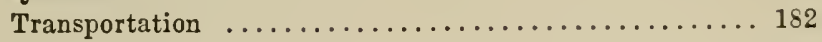

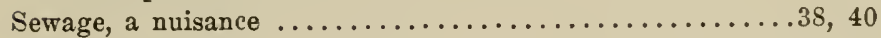

Need of state supervision.................. 217

Slaughterhouses-

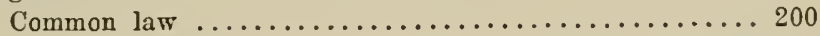

Federal supervision ....................... 188-198

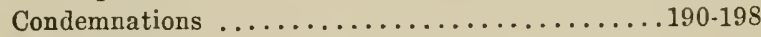

Meat inspection .................... 197

Prosecutions ........................ 196

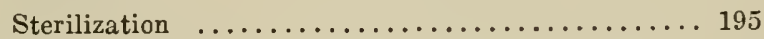

Intrastate Industries ..................... 198

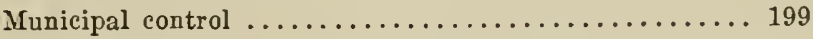

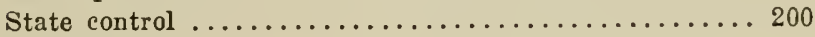

Stallions, etc.-

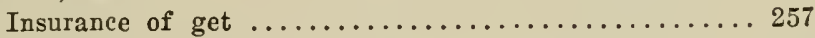

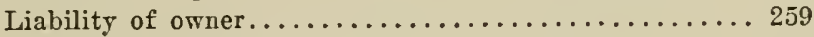

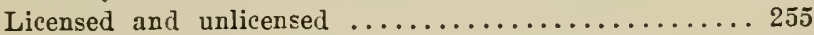

Liens for serrice .......................... 258

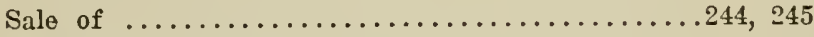

Warranty of heredity....................... 256 State-

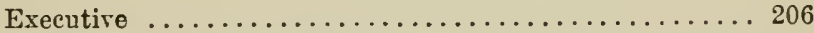

Jurisdiction orer sanitation ..............6, 146-149

Orer veterinary practice ................ 43

Orer slaughterhouses .................... 200

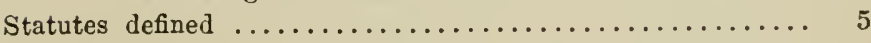

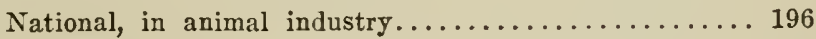

Sterilization of meat ....................... 195

Tapeworms in-

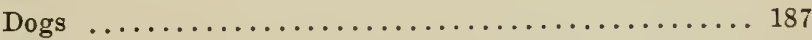

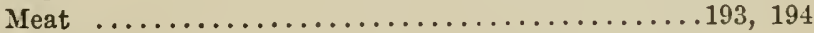

Texas cattle fever-

Arbitrary laws .......................... 14

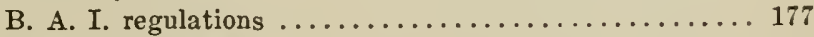

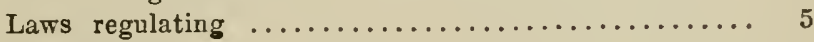

Liability for ......................... 154

Tubercular cattle-

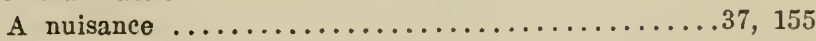

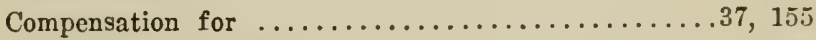

Condemnation of meat .................... 190 
Tubercular cattle (continued)-

Transportation ............................ 183

Tuberculin test $\ldots \ldots \ldots \ldots \ldots \ldots \ldots \ldots \ldots \ldots 1,170-183$

Unsoundness, Cases of $\ldots \ldots \ldots \ldots \ldots \ldots \ldots \ldots \ldots \ldots \ldots \ldots \ldots \ldots \ldots .239-240$

Veterinarian (See also Bailment, Compensation, Evidence, Liability, License, Liens, Records.) -

Right to practice-

Appointment in B. A. I................... 176

Appointment of license examiners.............53, 214

Attorney for board ....................... 63

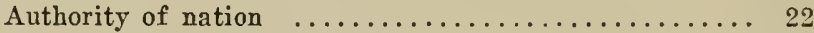

Authority of state .............................

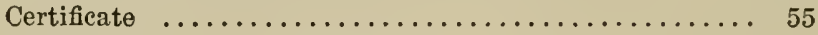

License-

Appeals ........................... 216

Exceptions in granting .................. 54

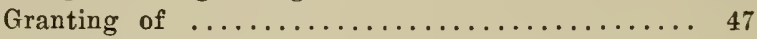

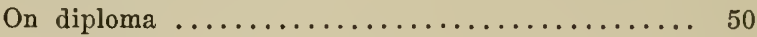

Reciprocal .......................... 55

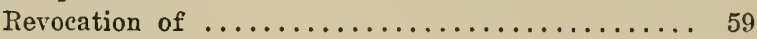

Standards for $\ldots \ldots \ldots \ldots \ldots \ldots \ldots \ldots \ldots \ldots \ldots \ldots$

Practice as a company..................... 67

Prosecution of illegal practitioners...........63, 68

What constitutes practice $\ldots \ldots \ldots \ldots \ldots \ldots \ldots \ldots .64$ Practice of-

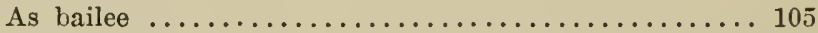

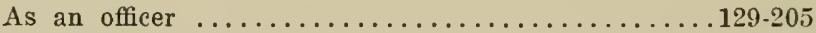

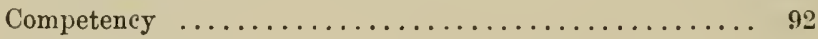

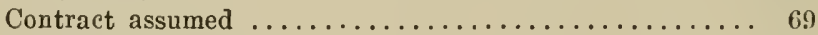

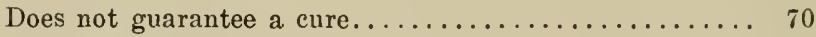

Gratuitous service .......................... 72

Liability ......................... 75

Liability of illegal practitioner.................. 89

Errors of judgment ................... 76

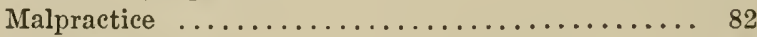

Survival of action $\ldots \ldots \ldots \ldots \ldots \ldots \ldots \ldots, 82$

Number of calls ........................ $\tau_{0}$

Obligation to attend $\ldots \ldots \ldots \ldots \ldots \ldots \ldots \ldots \ldots \ldots \ldots \ldots \ldots \ldots \ldots$

Right of action for fees.................... 93

By illegal practitioners .................. 94

Effect of malpractice upon................ 95

Skill required $\ldots \ldots \ldots \ldots \ldots \ldots \ldots \ldots \ldots \ldots, 71$ 
Veterinary Profession, status of $\ldots \ldots \ldots \ldots \ldots \ldots \ldots, 44,65$

And medical profession . . . . . . . . . . . . . 212

Veterinary schools; standards of ................ 49

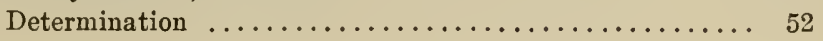

Warranty in breeding-

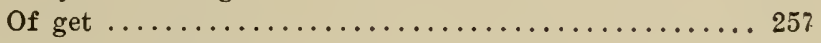

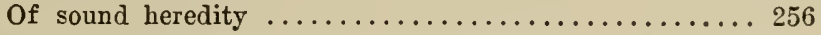

Warranty in sale-

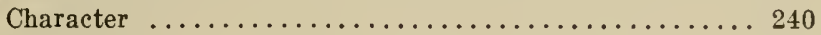

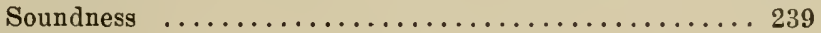

Witness-

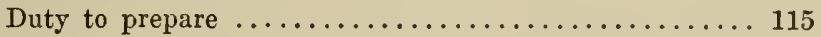

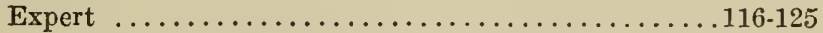

Definition and scope of expert testimony....... 117

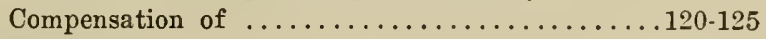

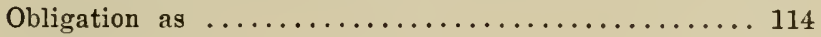

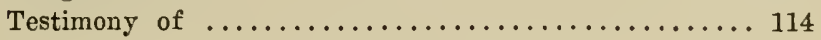





\title{
COLLECTING BY MAIL
}

\author{
By W. B. Parker.
}

Slow and bad accounts cause the average business or professional man much annoyance and loss, and are often the direct cause of bankriptcy. It, therefore, follows that any method of handling this class of accounts that shows a maximum of efficiency with a minimum of effort, friction and expense is worthy of serious consideration.

This article outlines a system that is the result of over fifteen years' experience of an attorney and credit man for several large business houses. It is adapted to either a large or small business, and equally well to accounts for professional services and has "made good" wherever adopted.

The basic idea is that a business man can, in most instances, handle his own collections to better advantage than by turning them over to collection agencies or others, and that it is neither necessary or politic to use bluffing or intimidating methods.

It has been found that the basic elements of a successful collection system are persistency and courtesy, not bluffs and threats. A severe storm, or a series of them, will have small effect on stone, while a constant dropping of water on the same spot will wear it away.

The plan here outlined consists of five letters and a legal postal card follow up system, and will keep after the slow debtor over forty-five. days at a total postal cost of not exceeding twenty cents. The forms given for the letters are to be written on the letter-heads of the person or firm using them and the card form on ordinary government postal cards. They will not be nearly as effective if printed and afterwards "filled in" and they are so short that it is not at all necessary to do so, even where several hundred accounts are involved, as onlv twenty-five minutes of a typist's time is required on any one account, even if it is necessary to continue the system to the very last card, which will very seldom happen.

When intending to use this system on a certain number of accounts, it is best to make an alphabetical list of them on a long sheet of paper, noting the name, address, amount and date of the last itcm, leaving about an inch of blank space after each account in which to note the dates of mailing the form letters and cards. When an account is paid or satisfactory arrangements made, it should be crossed off the list, thus leaving a correct list for the next mailing. 
Mr. Slow Pay,

\section{Letter No. 1}

Chicago, Ill.

Dear Sir:-

In looking over our books today we find a past due balance standing against you in the amount of \$—, running back to

Will you kindly mail us your check for this amount or advise us at once if you find the balance incorrect?

Thanking you in advance, we remain,

Yours very truly,

Mr. Slow Pay,

\section{Letter No, 2}

Chicago, Ill.

Dear Sir:-

We wrote you balance on your account of \$—_ running back to

regarding a past due

Please let us hear from you at once, so that we will know whether you consider the balance correct, and when we may expect your check.

Very truly yours,

Mr. Slow Pay,

Letter No. 3

Clicago, I11.

Dear Sir:-

Our letters of and regarding a past due balance of $\$$ - on your account remain unanswered.

It certainly seems to us that you might at least grant us the courtesy of an answer, even if it is inconvenient for you to send us your check just at this time.

Kindly favor us in this regard, and oblige,

Yours very truly,

Mr. Slow Pay

\section{Letter No. 4}

Chicago, Ill.

Dear Sir :-

We are much surprised at your failure to answer any of our several letters regarding your past due account. Our letters have certainly been courteous and we feel that we have treated you fairly in every way.

You know, of course, that unless we liear from you we will be compelled to adopt other means of collection which we very much dislike to do. 
It will save both of us useless expense and annoyance if you will let us hear from you at once, stating just what you propose to do.

The writer will hold this account on his desk until the morning of - and will depend upon hearing from you by that time.

Yours very truly,

\section{Letter No. 5}

Mr. Slow Pay, Chicago, Ill.

Dear Sir :-

As we did not hear from you this morning we have fully decided to take other steps to enforce settlement of that past due account.

However, a business acquaintance advises us that he believes you to be entirely prompt and reliable, and we have therefore decicled to wait a few days longer.

You must certainly realize that your credit standing depends on your fair dealing, and fair dealing certainly requires you to answer our letters.

Of course, we realize that it is entirely possible that you have neither received or read our previous letters personally. In view of the statement referred to above we sliall expect to hear from you at once.

$$
\text { Yours very truly, }
$$

\section{Postal Card Form}

We wrote you ——, - $\longrightarrow,-$, and - - No reply. Why? It is important that we hear from you at once.

Send the letters wcekly and cards every other day for 20 days, following letter No. 5, allowing three days for answer to last letter. linil in the blank spaces in the sccond line of card form with the rlates of the five preceding letters, as $1 / 1,1 / 7$, $1 / 14,1 / 21,1 / 2$, , thus making a second line of dates, in figures. Arld nothing to the wording of card form except signature. which should be written with pen, down toward right hand bottrin corner of card; do not date. The letters should be single spaced between lines and double spaced between paragraphs. 
It will be noted that the first three letters are very short indeed, and yet they say all that is necessary or advisable to say at this stage of the correspondence, and also ask a question that demands an answer whether the debtor is able to pay just at that time or not. They are so mild that they can be sent without giving offense, to perfectly good, but slow, debtors and ret they form an effective basis for the letters that follow to the slower and more doubtful debtors.

The fourth letter takes the place of the usual "threat to sue" letter, and is fully as effective, without committing the writer to any definite action whatever, but leaves the matter open so that he can effectively continue his mail campaign. The fifth letter is a reversal of the "threat to list" or let other business men know of the indebtedness, and is even more effective without being offensive. It flatters instead of threatens and winds up by giving the debtor an excuse for his past failures to respond to the letters that have been sent him.

But some men do not read letters and it does not much matter what you write them. Here is where the postal cards come in. While they say nothing whatever about an account, and are consequently perfectly legal, yet they furnish an inexpensive form of persistency that certainly does get results.

In conclusion, it is emphatically stated that this system will not get money from a man who has none, or secure any other impossible result, but it will bring in the most money out of the past due hundred dollars, if used according to instructions, and it certainly will not involve the user in unnecessary expense or useless litigation. 





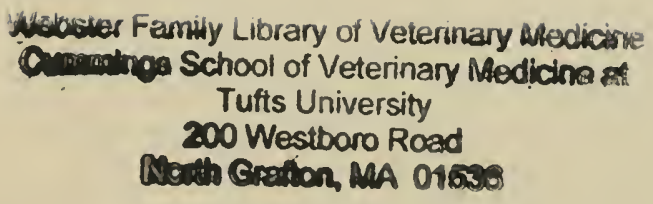



